TÓPICOS EM

\title{
Ciências
} Sociais

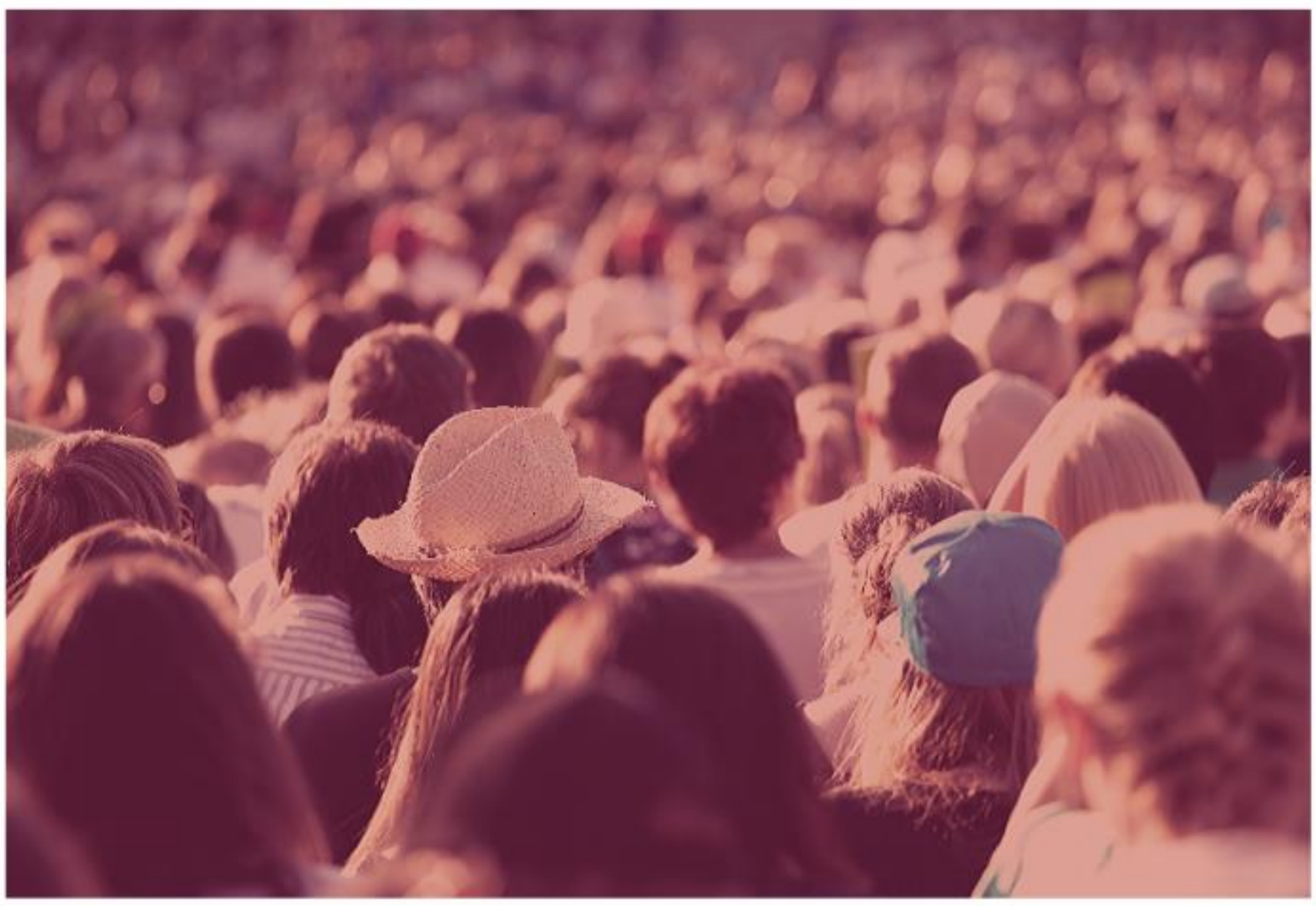

Volume 2

< > Editora Poisson 
Editora Poisson

\section{Tópicos em Ciências Sociais Volume 2}

1a Edição

Belo Horizonte

Poisson

2019 
Editor Chefe: Dr. Darly Fernando Andrade

\section{Conselho Editorial}

Dr. Antônio Artur de Souza - Universidade Federal de Minas Gerais

Ms. Davilson Eduardo Andrade

Dra. Elizângela de Jesus Oliveira - Universidade Federal do Amazonas

Msc. Fabiane dos Santos

Dr. José Eduardo Ferreira Lopes - Universidade Federal de Uberlândia

Dr. Otaviano Francisco Neves - Pontifícia Universidade Católica de Minas Gerais

Dr. Luiz Cláudio de Lima - Universidade FUMEC

Dr. Nelson Ferreira Filho - Faculdades Kennedy

Ms. Valdiney Alves de Oliveira - Universidade Federal de Uberlândia

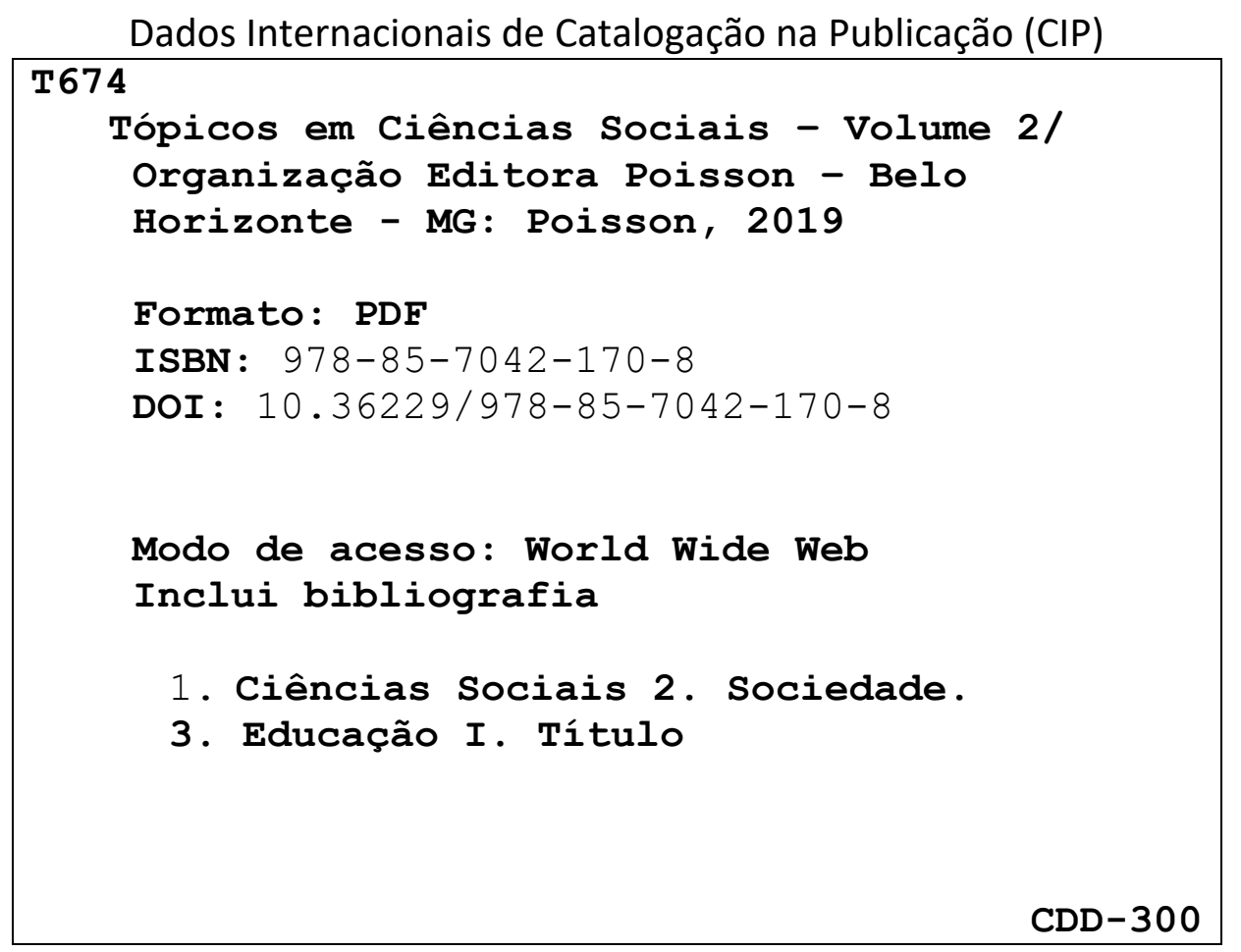

O conteúdo dos artigos e seus dados em sua forma, correção e confiabilidade são de responsabilidade exclusiva dos seus respectivos autores.

www.poisson.com.br

contato@poisson.com.br 


\section{SUMÁRIO}

Capítulo 1: Comunicação política no twitter: 0 uso das \#hashtags pelos presidenciáveis nas eleições de 2018 no Brasil .06

Doacir Gonçalves de Quadros, Romer Mottinha Santos

DOI: 10.36229/978-85-7042-170-8.CAP.01

Capítulo 2: As chacinas no Rio Grande do Norte em 2017:Consequências da ausência do Estado 15

Ivenio do Espirito Santo Hermes Junior, Thadeu de Sousa Brandão, Iara Mariana de Farias Nóbrega, Cindy Damaris Gomes Lira

DOI: $10.36229 / 978-85-7042-170-8 . C A P .02$

Capítulo 3: 0 Estado Inconstitucional das coisas na Saúde da Penitenciária Agrícola do Monte Cristo 25

Nathalie de Azevedo Kjaer, Débora Cristina Marinho Guimarães, Edson Juan Ferreira Nascimento, Antônio Sousa Martins Filho, Rui Machado Junior

DOI: 10.36229/978-85-7042-170-8.CAP.03

Capítulo 4: A educação em direitos humanos no Mercosul: Debates necessários na sociedade contemporânea 32

Rosane Beatris Mariano da Rocha Barcellos Terra, Maria Paula da Rosa Ferreira, Guilherme Streit Carraro, Rodrigo Cristiano Diehl

DOI: $10.36229 / 978-85-7042-170-8 . C A P .04$

Capítulo 5: Uma abordagem dos direitos da personalidade e os direitos do natimorto 41

Gleicemeri de Vito Monaro, Fabíola Cristina Carrero, Paulo Henrique Pavolak DOI: 10.36229/978-85-7042-170-8.CAP.05

Capítulo 6: Controle social e serviço social:Breve abordagem sobre a participação social no Conselho Municipal de Saúde. 49

Thais Tavares Bernardo, Luciane Cordeiro da Silva Mosca

DOI: 10.36229/978-85-7042-170-8.CAP.06

Capítulo 7: Políticas sociais em pequenos Municípios: Fundo público como diferencial no desenvolvimento 63

Edemar Rotta, Ivann Carlos Lago, Caroline Hentges

DOI: 10.36229/978-85-7042-170-8.CAP.07

Capítulo 8: A política de assistência social como determinante estratégico no combate à pobreza no Brasil. 74

Ana Virginia do Nascimento Moreira, Amanda Maria Cunha Menezes

DOI: $10.36229 / 978-85-7042-170-8 . C A P .08$ 


\section{SUMÁRIO}

Capítulo 9: Globalização e os impactos sobre as experiências migratórias dos haitianos no Oeste do Paraná. 87

Claudimara Cassoli Bortoloto

DOI: 10.36229/978-85-7042-170-8.CAP.09

Capítulo 10: Juventude rural: Entre o partir e o permanecer no campo. A dinâmica dos jovens rurais do Município de Bela Vista de Goiás (Goiás/Brasil). 97

Lorrany dos Santos Ferreira, Andréa Vettorassi

DOI: 10.36229/978-85-7042-170-8.CAP.10

Capítulo 11: O processo de estigmatização do "baiano" na cidade de Rio Grande - RS. 109

Pedro Marchioro, Pedro Robertt Niz

DOI: 10.36229/978-85-7042-170-8.CAP.11

Capítulo 12: A igreja bipolar 118

Miriam Barbosa

DOI: $10.36229 / 978-85-7042-170-8 . C A P .12$

Capítulo 13: Direito ao esquecimento: Balanço entre Brasil e Espanha 126

Anna Lúcia Noschang da Silva, Valéria Ribas do Nascimento

DOI: 10.36229/978-85-7042-170-8.CAP.13

Autores: 


\section{Capítulo 1}

\section{Comunicação política no twitter: O uso das \#hashtags pelos presidenciáveis nas eleições de 2018 no Brasil}

\section{Doacir Gonçalves de Quadros \\ Romer Mottinha Santos}

Resumo: 0 objetivo neste artigo é analisar como o Twitter é utilizado pelos candidatos à presidência do Brasil nas eleições de 2018. A metodologia de pesquisa é quantitativa e de análise de conteúdo com utilização do aplicativo Twitonomy para a captura de dados publicados entre 15 de agosto até 07 de outubro de 2018. Uma primeira conclusão mostrou que os candidatos à presidência do Brasil são compelidos a usar o Twitter de modo a criar um sistema eleitoral on-line. Uma segunda conclusão mostra que, para atingir o potencial máximo de mobilização que o Twitter permite, deve-se saber o que, quando e como postar. E, por fim os candidatos usaram o Twitter predominantemente para a construção da imagem, para mobilização e engajamento dos simpatizantes.

Palavras-chave: Lideranças Políticas; Twitter; Comunicação Política, Eleições 2018; Internet. 


\section{INTRODUÇÃO}

Estudos recentes mostram que a política no Twitter pressiona lideranças políticas a possuírem perfis na ferramenta digital como um espaço útil para fazerem a divulgação de informações e opiniões pessoais de modo a não ficarem dependentes da cobertura dada pelos meios de comunicação tradicionais como é o caso da televisão, do jornal e do rádio. Neste artigo pressupõe-se, por um lado, que durante as disputas eleitorais a comunicação no Twitter é mais um canal de comunicação entre a liderança política em específico o candidato com o seu eleitor. E, por outro lado, pela comunicação via Twitter a liderança política tem a possibilidade de tomar inúmeras iniciativas que contribui para a construção da candidatura e para a administração da popularidade durante a disputa a cargos eletivos.

É em torno deste contexto que se desenvolve o objetivo neste artigo: analisar como o Twitter é utilizado pelos candidatos à presidência do Brasil nas eleições de 2018. A metodologia de pesquisa adotada aqui é a quantitativa e de análise de conteúdo com utilização do aplicativo Twitonomy para a captura das postagens nos perfis oficiais do Twitter dos presidenciáveis. 0 período de captura de postagens é de 15 de agosto a 07 de outubro de 2018. Os dados coletados nos perfis referem-se a: número de tweets do perfil; número de seguidores (followers); número de usuários do Twitter que o perfil segue (following); ano de ingresso do perfil do candidato no Twitter e percentual de hashtags mais usadas pelo perfil. A hipótese que norteia a análise é a de que no uso do Twitter pelos presidenciáveis predomina a estratégia de divulgar hashtags que convergem para a construção da candidatura e para administração da popularidade dos presidenciáveis. Pelas hashtags é possível os presidenciáveis: i) agregarem a sua candidatura um enquadramento favorável sobre temas e assuntos; ii) mobilizar usuários e seguidores em torno de sua campanha; iii) ter o contato direto com os usuários da mídia social sem a intermediação da imprensa.

A seguir, dissertamos sobre o Twitter e a comunicação política, sobre a importância da construção da imagem política em torno de uma popularidade positiva e sobre a internet como um instrumento para a promoção de tal imagem.

\section{A INTERNET E A COMUNICAÇÃO POLÍTICA}

Em específico ao Brasil desde 1988 presenciamos o avanço da internet; segundo o IBGE (Instituto Brasileiro de Geografia e Estatística), houve um avanço no acesso à internet durante as três últimas décadas, de modo que em 2015 49,4\% da população brasileira tinham acesso à internet em casa. Esse avanço foi favorecido e muito pelo aumento nas vendas de smartfones, tablets e televisão com wi-fi. Esse ambiente virtual que a internet possibilita para divulgar informações e propagandas e quando comparado com o espaço oferecido por jornal, rádio e televisão proporciona novas iniciativas para fazer as campanhas eleitorais. Esse ambiente virtual tem impelido partidos e lideranças políticas a possuir redes e mídias sociais que servem como canais para a divulgação dos seus projetos políticos, para a apresentação de seus candidatos, propostas e para mobilização de seus eleitores, simpatizantes e militantes (Braga et al., 2009). Essa ampliação do sistema virtual oferecido pela internet aos partidos e às lideranças políticas têm estimulado a pesquisa entre investigadores da ciência política e da comunicação social. Enquanto entre os pesquisadores da área da comunicação pergunta-se se por meio das plataformas digitais há novas e eficientes maneiras de fazer-se propaganda, os pesquisadores da ciência política questionam se com o uso das plataformas digitais está havendo alterações na forma de se fazer política e se está ocorrendo modificações em algumas premissas democráticas no que se refere a mobilização e participação política.

Neste artigo a reflexão proposta se aproxima as preocupações dos cientistas políticos em que se procura identificar como o uso da internet está proporcionando novas iniciativas para fazer-se política. $\mathrm{Na}$ área da ciência política há um crescimento no número de pesquisas que investigam o uso das redes e mídias sociais pelos partidos e lideranças políticas (Carvalho, 2013; Stromer-Galley, 2013). Grosso modo, essas pesquisas investigam os websites, Facebook, Twitter, YouTube e blogs; dentre as principais questões que motivam esses estudos estão: (i) explorar como os partidos políticos e lideranças políticas estão fazendo uso dos recursos de interação e de comunicação que a internet oferece; (ii) qual o público-alvo atingindo por meio da web; (iii) comparar o uso da internet pelos diferentes partidos e lideranças políticas. É frente a essa reflexão teórica que se percebe a importância dos estudos como o nosso, que se propõem a explorar o uso da internet e seus recursos - websites, Twitter, Facebook, blogs - na expectativa de compreender melhor como a internet está contribuindo para que os partidos e lideranças políticas aperfeiçoem gastos financeiros, materiais e estratégias de campanhas por meio da utilização da internet.

E neste contexto o Twitter demonstra ser uma ferramenta de grande impacto de mobilização social, pois suas características lhe conferem um imediatismo e escopo que nenhuma outra mídia social permite. Isso 
pode ser um paradoxo: a mesma capacidade e velocidade de difusão, adicionado com a limitação de caracteres de uma rede de micro blogs, tem sido uma fonte frequente de informações não compreendidas e confrontos entre usuários. 0 anonimato e a impunidade que daí decorrem serviram de cobertura para situações de assédio e manipulação, bem como para a geração de rumores falsos ou manipulação de evidências (Caldevilla Domínguez, et al., 2019).

\section{POPULARIDADE, INTERNET E OPINIÃO PÚBLICA}

Os meios de comunicação - rádio, jornal, televisão e internet - ocupam uma posição de destaque e centralidade nas sociedades contemporâneas, mediando diversos aspectos das atividades humanas. Como explica Lima (2004), esses meios tendem a contribuir para a construção do conhecimento público, para a reflexão e para a tomada de decisão dos cidadãos no campo político, por exemplo. Bernard Manin (1995) ressalta que os meios de comunicação apresentam-se como os principais canais de difusão de informação e tornam-se mediadores entre a esfera política e a esfera civil.

A visibilidade pública é um dos aspectos fundamentais para a vida política. Dependentes do voto e da avaliação popular, os atores políticos - candidatos, representantes e partidos políticos - passam a disputar espaço nos meios de comunicação (Marques, 2014). A finalidade dessa disputa é a construção e a manutenção de uma imagem pública que garanta a conquista e a manutenção no poder.

As disputas nas eleições não acontecem mais exclusivamente no quadro de uma esfera pública assegurada institucionalmente por meio de uma prolongada disputa de opiniões. Em vez de um debate profundo de ideias entre os candidatos acerca dos principais problemas relativos à gestão do espaço público, entra em cena a importância do índice de popularidade como foco da disputa eleitoral para conquistar o voto do eleitor (Habermas, 2006, 2014). Consequentemente, tudo que for noticiável precisa ser traduzível em aumento de popularidade positiva para os aspirantes a cargos eletivos. De acordo com J. B. Thompson (2002, p. 299), a popularidade positiva do político é traduzida em reputação e em relações de confiança que o político constrói durante sua história política e pessoal. Reputação e confiança passam, portanto, a ser bens necessários para que os candidatos conquistem a opinião pública e a vitória política e eleitoral. No que se refere à construção da imagem política em torno de uma popularidade positiva, a internet mostra-se como um instrumento que permite reais condições para a promoção de uma imagem positiva, de modo que por ela ocorre um amplo aumento no volume de informações rápidas e atualizadas que são disponíveis de maneira mais fácil.

No mundo da internet o Twitter é uma ferramenta de comunicação política que se mostra como um espaço de ressonância de temas e notícias que repercutem nos meios de comunicação e influência na opinião pública (Rossetto et.al, 2013, p. 191). ${ }^{2}$ No que diz respeito às temáticas que se concentram atualmente nos estudos sobre Twitter, encontramos as seguintes linhas: (i) linguagem e comportamento; (ii) jornalismo digital; (iii) ciberativismo; (iv) práticas mercadológicas publicitárias; (v) apropriação política.

Este estudo filia-se à linha temática "apropriação política", que designa estudos relacionados à apropriação do Twitter em períodos eleitorais. Como mídias sociais e como espaços de debates de temas políticos, o Twitter e o Facebook proporcionaram vários episódios que foram merecedores de estudos detalhados e sistemáticos ${ }^{3}$. É o caso, por exemplo, da campanha eleitoral para presidente do Brasil em 2014, que ocupou grande espaço no Twitter (Conceição, 2017). Todos os candidatos à Presidência da República mantiveram contas oficiais no Twitter e no Facebook, utilizando os portais de mídia social diariamente em suas campanhas, buscando atuar de maneira próxima a seus eleitores. Diante desse cenário da política no Twitter, parece-nos relevante estudar os discursos construídos na plataforma pelos candidatos, na medida em que a circulação de informações sobre os candidatos é fundamental para a escolha do eleitor (Recuero, 2016, p. 158-159).

$2 \quad 0$ Twitter como mídia social apresenta algumas peculiaridades. Foi criada em 2006 e permite aos seus usuários escrever mensagens de 140 caracteres. De acordo com os dados fornecidos pela própria empresa Twitter (2018) o número de usuários ativos mensalmente corresponde a 335 milhões em todo mundo, conforme o levantamento publicado em 27 de julho de 2018 (Moraes \& Santos, 2016).

3 No início desta década houve a eclosão simultânea de movimentos sociais de protestos via mídias sociais catalisando mobilizações e protestos que repercutiram globalmente (Carneiro, 2012, p. 7). 0 movimento global foi protagonizado especialmente pela nova geração de internautas, em especial via Twitter, disseminando informações com mensagens replicadas para milhares de outros emissores (Carneiro, 2012, p. 9). 


\section{ELEIÇÃO PRESIDENCIAL DE 2018}

Em meio a um cenário político conturbado com o afastamento da Presidente Dilma Rousseff desde 2016, políticos e partidos alinhavam alianças políticas e trabalhavam na construção de suas imagens nos principais meios de comunicação do país, televisão e internet, tendo como foco a disputa para as eleições que ocorrem em 2018. Apesar de a Resolução n. 23.551, de 18 de dezembro de 2017, expedida pelo Tribunal Superior Eleitoral (TSE), definir que a propaganda eleitoral no rádio, na televisão e na internet serem lícitas somente a partir de 16 de agosto de 2018,

O cenário eleitoral de 2018 no Brasil para a disputa presidencial possui alguns fatores distintos das eleições anteriores. Desde 2013 o país passou por vários protestos de rua contra o governo e o combate à corrupção como uma das principais pautas. Com o impeachment da ex-presidente Dilma Rousseff (PT) e posteriormente o governo Michel Temer (MDB) apresentou níveis de reprovação elevados, crise econômica e crise de imoralidades. Em 2017 a reforma eleitoral proporcionou algumas mudanças significativas para eleitores e candidatos. A campanha eleitoral de 2018 foi mais curta iniciando em 16 de agosto, são 45 dias de exposição oficial dos candidatos, metade do período das eleições de 2014. Mas o início do horário eleitoral gratuito é apenas em 31 de agosto. 0 tempo menor aumentou a importância das coligações, que garantem mais tempo do horário eleitoral gratuito no rádio e televisão, além da distribuição de verba pública do fundo eleitoral.

Todavia, o número de 13 presidenciáveis dificulta a composição de coligações majoritárias, tornando a disputa pulverizada. Entre os presidenciáveis há candidatos em sua primeira disputa e também nomes que já participaram de pleitos anteriores.

A candidatura do ex-presidente Lula (PT) era uma incógnita, pois desde 7 de abril de 2018 estava preso na sede da polícia Federal em Curitiba, condenado no caso do tríplex de Guarujá, resultante da Operação Lava Jato. Em decisão anunciada em 11 de setembro de 2018 (último dia de prazo dado pelo TSE para substituição de candidato) o PT registrou a candidatura de Fernando Haddad. 0 deputado federal Jair Bolsonaro (PSL) em sua primeira disputa presidencial apresentou-se como um forte concorrente nas pesquisas eleitorais. Sua conduta prioriza o combate à esquerda com um posicionamento nacionalista e conservador. 0 senador Álvaro Dias (Podemos) do Paraná apresenta-se como uma candidatura de centro alternativa aos candidatos do PT e PSDB que polarizaram as disputas presidenciais desde 1994. Geraldo Alckmin (PSDB), o ex-governador de São Paulo participou da segunda disputa presidencial. Sua coligação conquistou o maior número de partidos e o maior tempo de campanha eleitoral na TV e no rádio.

O candidato Ciro Gomes (PDT) já participou em eleições anteriores pela presidência, além de possuir experiência política como governador, prefeito, deputado federal e estadual e ministro. Guilherme Boulos (PSOL) é uma novidade dos partidos de esquerda e Coordenador Nacional do Movimento dos Trabalhadores Sem Teto (MTST). O candidato do governo Henrique Meirelles (MDB), ex-ministro da Fazenda e ex-presidente do Banco Central disputou a eleição presidencial pela primeira vez. João Amoedo (NOVO) é o candidato oriundo do mercado financeiro, em sua primeira corrida presidencial é um outsider na disputa. A candidata Marina Silva (REDE), ex-ministra do Meio Ambiente, está em sua terceira disputa presidencial e em 2014 após assumir a candidatura do falecido Eduardo Campos (PSB) quase interrompeu a polarização PT \& PSDB, mas acabou sendo a terceira mais votada pelos eleitores.

0 deputado federal Cabo Daciolo (Patriotas) é outro candidato que disputou a eleição presidencial pela primeira vez. João Vicente Goulart Filho (PPL) também está pela primeira vez na corrida presidencial. 0 candidato é filho do ex-presidente João Goulart, deposto pela ditadura militar em 1964. A candidata Vera Lúcia (PSTU) é uma representante da esquerda que também disputa a presidência pela primeira vez. 0 candidato José Maria Eymael (DC) foi candidato a presidente da República nas eleições de 1998, 2006, 2010 e 2014, mas nunca figurou entre os líderes de intenção de voto.

\section{APONTAMENTOS METODOLÓGICOS.}

0 recorte temporal desta pesquisa é de 15 de agosto até 07 de outubro de 2018 (data da eleição de $1^{\circ}$ turno). Optou-se pela limitação da coleta no perfil do Twitter dos presidenciáveis ao ano de 2018 por ser o ano eleitoral e pelo fato de que os candidatos têm data de adesões distintas nesta mídia social. 0 calendário eleitoral de acordo com o Tribunal Superior Eleitoral determina que as convenções partidárias fossem realizadas até 05 de agosto, por isso as candidaturas após esta data já estão pré-definidas até o dia 15 de agosto, que é o fim do prazo para registro de candidaturas. Para esta pesquisa que aborda o perfil oficial no Twitter dos candidatos à presidência da República para as eleições no Brasil em 2018 foram selecionados os seguintes candidatos: 
1) Marina Silva (REDE), @MarinaSilva;

2) Jair Bolsonaro (PSL), @jairbolsonaro;

3) Geraldo Alckmin (PSDB), @geraldoalckmin;

4) José Maria Eymael (DC), @Eymaeloficial;

5) Álvaro Dias (PODE), @alvarodias_;

6) Luiz Inácio Lula da Silva (PT), @LulaOficial - [substituído por Fernando Haddad (PT), @Haddad_Fernando];

7) Vera Lúcia (PSTU), @verapstu;

8) Ciro Gomes (PDT), @cirogomes;

9) João Amoedo (NOVO), @joaoamoedonovo;

10) João Vicente Goulart Filho (PPL), @joaogoulart54;

11) Henrique Meirelles (MDB), @meirelles;

12) Cabo Daciolo (Patriota), @CaboDaciolo;

13) Guilherme Boulos (PSOL), @GuilhermeBoulos.

As variáveis coletadas no Twitter dos presidenciáveis se referem a:

I) Número de tweets do perfil,

II) Número de seguidores (followers),

III) Número que o perfil segue (following),

IV) Ingresso do perfil no Twitter,

V) hashtags mais utilizadas pelo perfil.

A coleta foi realizada pelo aplicativo (API) Twitonomy, que obtêm informações do Twitter e permite gerar planilhas, gráficos e relatórios dos perfis selecionados. Entre as principais funcionalidades da ferramenta Twitonomy destaca-se que ela apresenta estatísticas sobre o perfil analisado como, por exemplo, a quantidade de tweets postados e o agrupamento de hashtags utilizadas pelo usuário (Herman, 2017, p. 147-148).

A categorização para a classificação das hashtags é adaptada da pesquisa "Campanha eleitoral no Twitter: as estratégias dos candidatos na disputa para a Prefeitura de Curitiba em 2016", de Fellipe Herman (2017, p. 149-150). As hashtags são termos ou palavras-chaves escritos sem espaços antecedidos por uma cerquilha "\#” (também chamado de sustenido). São utilizadas para categorizar conteúdo em mídias sociais. Por meio delas os conectados à rede podem buscar um conteúdo com mais facilidade e com maior rapidez. Além é claro de divulgar informações de determinadas temáticas com melhores possibilidades de filtros e engajamento. Por um lado, as hashtags mais utilizadas pelos candidatos demonstram não apenas para que fim eles utilizam o Twitter, e por outro lado, mostra qual o padrão de informação que eles direcionam aos seus seguidores e ao público em geral. São sete categorias conforme o Quadro 1: 
Quadro 1. Categoria de temas para hashtags (\#) dos presidenciáveis

\begin{tabular}{|c|c|}
\hline Categoria & Descrição \\
\hline Agenda e eventos & $\begin{array}{l}\text { Temas relacionados à divulgação de agenda e eventos do candidato, como visita a } \\
\text { lugares e entrevistas. }\end{array}$ \\
\hline Imagem do candidato & $\begin{array}{l}\text { Divulgação de realizações pregressas vinculadas à sua imagem pessoal, de } \\
\text { candidato, político ou institucional. }\end{array}$ \\
\hline Posicionamento & $\begin{array}{l}\text { Posicionamento do candidato referente a ideologia, como posição política, ou a } \\
\text { manifestações da população, como protestos. }\end{array}$ \\
\hline Campanha negativa & Ataques a adversários e críticas. \\
\hline Mobilização engajamento & Relacionado à participação e mobilização. \\
\hline Promessas e projetos & Divulgação de projetos, propostas e promessas. \\
\hline Outros & Categorias não englobadas anteriormente. \\
\hline
\end{tabular}

\section{A ANÁLISE DAS \#HASHTAGS}

É pertinente destacar que todos os candidatos à presidência possuem um perfil registrado no Twitter. Ou seja, ter uma mídia social é uma ferramenta digital importante para a comunicação política e eleitoral. A utilização do Twitter pelos presidenciáveis para postagens no período eleitoral do $1^{\circ}$ turno em 2018 foi de alto volume para a maioria dos candidatos, conforme o Quadro 2. 0 que demonstra que a ferramenta é significativamente pertinente para suas campanhas. 0 perfil de Meirelles (MDB) que apesar de ter ingressado nesta mídia social apenas em 2017 obteve uma média de 65,31 tweets diários de publicações. Lula (PT) com 34,35, Amoêdo (NOVO) com 28,26, Álvaro Dias (PODE) com 26,41, Boulos (PSOL) com 18,65, Haddad (PT) com 14,78, Alckmin (PSDB) com 13,13, Marina (REDE) com 10,06 e Bolsonaro (PSL) com 8,39 de média de tweets diários também demonstraram um grande fluxo de publicações. Isso demonstra também que a equipe de comunicação dos candidatos prioriza esta mídia social.

Quadro 2. Tweets dos presidenciáveis 2018 no Brasil (1º turno: 15-08-2018 a 07-10-2018)

\begin{tabular}{|c|c|c|c|c|c|}
\hline Candidatos 2018 & $\begin{array}{l}\text { Tweets } \\
\text { Analytics }\end{array}$ & $\begin{array}{l}\text { Média de } \\
\text { tweets por dia }\end{array}$ & $\begin{array}{l}\text { Ingresso no } \\
\text { Twitter }\end{array}$ & $\begin{array}{l}\text { Seguidores } \\
\text { (followers) }\end{array}$ & $\begin{array}{l}\text { N. total de Tweets } \\
\text { desde a adesão a } \\
\text { mídia social }\end{array}$ \\
\hline $\begin{array}{l}\text { Henrique Meirelles } \\
\text { (MDB) }\end{array}$ & 3200 & 65,31 & $31 / 05 / 2017$ & 66.594 & 4.311 \\
\hline Lula (PT) & 1855 & 34,35 & $22 / 07 / 2014$ & 460.423 & 16.521 \\
\hline João Amoêdo (NOVO) & 1526 & 28,26 & $23 / 02 / 2011$ & 233.158 & 4.463 \\
\hline Álvaro Dias (PODE) & 1426 & 26,41 & $12 / 09 / 2009$ & 360.547 & 108.700 \\
\hline Ciro Gomes (PDT) & 1149 & 21,28 & $20 / 04 / 2009$ & 422.791 & 2.192 \\
\hline Guilherme Boulos (PSOL) & 1007 & 18,65 & $07 / 08 / 2016$ & 183.678 & 3.126 \\
\hline Fernando Haddad (PT) & 0798 & 14,78 & $13 / 08 / 2011$ & 765.703 & 2.766 \\
\hline Geraldo Alckmin (PSDB) & 0709 & 13,13 & $14 / 09 / 2009$ & 994.495 & 33.612 \\
\hline Marina Silva (REDE) & 0543 & 10,06 & $15 / 01 / 2010$ & 1.909 .285 & 9.429 \\
\hline Jair Bolsonaro (PSL) & 0453 & 8,39 & $31 / 03 / 2010$ & 1.695 .892 & 5.045 \\
\hline Vera Lúcia (PSTU) & 0130 & 2,41 & $13 / 07 / 2012$ & 1.856 & 2.309 \\
\hline $\begin{array}{l}\text { João V. Goulart Filho } \\
\text { (PPL) }\end{array}$ & 0079 & 1,46 & $23 / 03 / 2015$ & 1.737 & 90 \\
\hline Cabo Daciolo (Patriota) & 0051 & 0,94 & $27 / 04 / 2018$ & 97.410 & 62 \\
\hline José Maria Eymael (DC) & 0035 & 0,65 & $13 / 09 / 2009$ & 23.804 & 20.542 \\
\hline
\end{tabular}

FONTE: Elaboração dos autores via Twitonomy (2018).

Apesar de todos os candidatos terem aderido ao Twitter, o número de seguidores no perfil dos presidenciáveis é bem distinto demonstrando que a data de ingresso e o número de tweets aparentemente não tem uma relação direta para este resultado. Ao final do primeiro turno os candidatos que avançaram ao segundo turno foram Bolsonaro e Haddad, no entanto (conforme Quadro 2) observa-se que Marina Silva (REDE) contava com mais de um milhão e novecentos mil seguidores, de acordo com estes números podemos presumir que para os seguidores da candidata o Twitter é um canal de comunicação com a candidata. 0 fato da Marina Silva já ter concorrido nas duas eleições presidenciais anteriores (2010 e 
2014) e já ser usuária assídua do Twitter são fatores que podem explicar o elevado número de seguidores em relação aos demais candidatos.

Tabela 1. Perfil no Twitter dos candidatos à presidência do Brasil em 2018 (hashtags mais utilizadas $15 / 08 / 2019-07 / 10 / 2019$ )

\begin{tabular}{|c|c|c|}
\hline Candidato 2018 & Hashtags + utilizadas (most used) & $\begin{array}{l}\text { Categorias } \\
\text { predominantes das } \\
\text { hashtags }\end{array}$ \\
\hline Lula (PT) & $\begin{array}{l}\text { \#lulapresidente (188), \#haddadpresidente (186), \#vote13 (75), } \\
\text { \#lulalivrejá (68), \#voteporlulavote13 (49), \#lulaÉhaddad (47), } \\
\text { \#haddadÉ13 (44), \#debatenaglobo (41), \#lulalivre (29) }\end{array}$ & $\begin{array}{l}\text { Imagem do candidato } \\
\text { / Mobilização } \\
\text { engajamento }\end{array}$ \\
\hline $\begin{array}{l}\text { Fernando Haddad } \\
\text { (PT) }\end{array}$ & $\begin{array}{l}\text { \#haddadpresidente (122), \#vote13 (76), \#lulapresidente (75), } \\
\text { \#voteporlulavote13 (52), \#haddadÉ13 (41), \#debatenaglobo (32), } \\
\text { \#haddadaovivo (24) }\end{array}$ & $\begin{array}{l}\text { Imagem do candidato } \\
\text { / Mobilização } \\
\text { engajamento }\end{array}$ \\
\hline $\begin{array}{l}\text { Jair Bolsonaro } \\
\text { (PSL) }\end{array}$ & $\begin{array}{l}\text { \#jairmessiasbolsonaro (2), \#votobolsonaro17 (2), } \\
\text { \#bolsonaropresidente17 (1), \#bolsonaronaredetv (1), } \\
\text { \#lulapresidiário (1), \#capitãobolsonaro (1) }\end{array}$ & $\begin{array}{l}\text { Imagem do candidato } \\
\text { / Mobilização } \\
\text { engajamento }\end{array}$ \\
\hline $\begin{array}{l}\text { Geraldo Alckmin } \\
\text { (PSDB) }\end{array}$ & $\begin{array}{l}\text { \#geraldo45 (152), \#equipega (70), \#geraldopresidente (47), } \\
\text { \#debatenaglobo (20), \#anaaméliavice (19), \#pergunteaogeraldo45 } \\
\text { (18), \#ovotonarecord (15), }\end{array}$ & $\begin{array}{l}\text { Imagem do candidato } \\
\text { / Mobilização } \\
\text { engajamento }\end{array}$ \\
\hline Ciro Gomes (PDT) & $\begin{array}{l}\text { \#ciro12 (713), \#cirosim (197), \#ciropresidente (155), } \\
\text { \#cironaglobo (126), \#tsunamiciro (120), \#debateaparecida (76), } \\
\text { \#cironarecord (75), \#cironacnbb (74), \#uolnasurnas (69), } \\
\text { \#ovotonarecord (65) }\end{array}$ & $\begin{array}{l}\text { Imagem do candidato } \\
\text { / Mobilização } \\
\text { engajamento }\end{array}$ \\
\hline $\begin{array}{l}\text { Marina Silva } \\
\text { (REDE) }\end{array}$ & $\begin{array}{l}\text { \#votemarina18 (173), \#marina18 (83), \#vote18 (62), \#elasim (38), } \\
\text { \#debatenaglobo (19), \#pergunteamarina (19), \#debateredetv (15), } \\
\text { \#debatesbt (13), \#debateaparecida (13), \#gazetaestadaojp (11) }\end{array}$ & $\begin{array}{l}\text { Imagem do candidato } \\
\text { / Mobilização } \\
\text { engajamento / } \\
\text { Agenda e eventos }\end{array}$ \\
\hline $\begin{array}{l}\text { João V. Goulart } \\
\text { Filho (PPL) }\end{array}$ & $\begin{array}{l}\text { \#quemgostadobrasilvotanele (8), \#quemgostadobrasilvota54 (4), } \\
\text { \#jangofilho54 (4), \#eleições2018 (4), \#compromissojangofilho54 } \\
\text { (3), \#joãogoulartfilho54 (2) }\end{array}$ & $\begin{array}{l}\text { Imagem do candidato } \\
\text { / Mobilização } \\
\text { engajamento }\end{array}$ \\
\hline $\begin{array}{l}\text { Cabo Daciolo } \\
\text { (Patriota) }\end{array}$ & $\begin{array}{l}\text { \#cabodaciolo (3), \#daciolonaglobo (2), \#daciolo (2), \#daciolo51 } \\
\text { (1), \#debaterecord (1), \#daciolopresidente2018 (1), } \\
\text { \#marianagodoy (1) }\end{array}$ & $\begin{array}{l}\text { Imagem do candidato } \\
\text { / Agenda e eventos }\end{array}$ \\
\hline $\begin{array}{l}\text { Alvaro Dias } \\
\text { (PODE) }\end{array}$ & $\begin{array}{l}\text { \#alvarodias19 (613), \#equipead19 (37), \# gazetaestadaojp } \\
\text { (28), \#pergunteaoalvaro (27), \#debateredetv (24), } \\
\text { \#debatenarecord (23), \#debatenaglobo (22), \#abreoolho } \\
\text { (19), \#alvaronarecord (16), \#eleicoes2018 (14) }\end{array}$ & $\begin{array}{l}\text { Imagem do } \\
\text { candidato / Agenda } \\
\text { e eventos }\end{array}$ \\
\hline $\begin{array}{l}\text { Guilherme } \\
\text { Boulos (PSOL) }\end{array}$ & $\begin{array}{l}\text { \#boulosesonia50 (134), \#boulosaovivo (69), } \\
\text { \#votenoqueacredita (69), \#boulos50 (66), \#diab (63), } \\
\text { \#equipe (41), \#debatenaglobo (28), \#debateredetv (28), } \\
\text { \#boulosnaglobo (26), \#boulosnagazeta (24) }\end{array}$ & $\begin{array}{l}\text { Imagem do } \\
\text { candidato / } \\
\text { Mobilização } \\
\text { engajamento / } \\
\text { Agenda e eventos }\end{array}$ \\
\hline $\begin{array}{l}\text { José Maria } \\
\text { Eymael (DC) }\end{array}$ & \#pergunteaoeymael (20) & $\begin{array}{l}\text { Imagem do } \\
\text { candidato }\end{array}$ \\
\hline $\begin{array}{c}\text { Henrique } \\
\text { Meirelles (MDB) }\end{array}$ & $\begin{array}{c}\text { \# equipehm (2665), \#chamaomeirelles (2118), \#meirelles15 } \\
\text { (1228), \#votemeirelles15 (908), \#chamaomeirelles15 (686), } \\
\text { \#eleicoes2018 (145), \#bolsominion (105), \#gazetaestadaojp } \\
\text { (43), \#pergunteaomeirelles15 (36), \#uolnasurnas (35) }\end{array}$ & $\begin{array}{l}\text { Imagem do } \\
\text { candidato / } \\
\text { Mobilização } \\
\text { engajamento }\end{array}$ \\
\hline $\begin{array}{l}\text { Vera Lúcia } \\
\text { (PSTU) }\end{array}$ & $\begin{array}{c}\text { \#pstu16 (49), \#tôcomvera (48), \#veraresponde (22), } \\
\text { \#equipevera16 (18), \#umchamadoÀrebelião (11), \#elenão } \\
\text { (5) }\end{array}$ & $\begin{array}{l}\text { Imagem do } \\
\text { candidato }\end{array}$ \\
\hline $\begin{array}{l}\text { João Amoêdo } \\
\text { (NOVO) }\end{array}$ & $\begin{array}{l}\text { \#equipeja (554), \#vemcomjoão30 (446), } \\
\text { \#vamosrenovartudo (207), \#joãocom6 (52), \#vote30 (50), } \\
\text { \#joaocom6 (27), \#ondalaranja (20), \#pergunteaojoão (19), } \\
\text { \#euvotonojoão30 (18), \#joãonosdebates (16) }\end{array}$ & $\begin{array}{l}\text { Imagem do } \\
\text { candidato / } \\
\text { Mobilização } \\
\text { engajamento }\end{array}$ \\
\hline
\end{tabular}


O padrão de comunicação eleitoral dos presidenciáveis por hashtags demonstrou uma característica predominante para todos os candidatos, a priorização para a "Imagem do Candidato". A "Mobilização e engajamento" e "Agenda e eventos" também são categorias de hashtags bem utilizadas pelos candidatos para pedir votos e divulgar os compromissos de campanha. Como esta análise é apenas sobre as hashtags e não sobre o texto completo dos tweets e o número de hashtags dos presidenciáveis é bastante distinto, as categorias "Posicionamento" e "Campanha Negativa" não tiveram destaque nesta modalidade de análise desta pesquisa.

O primeiro resultado que merece destaque é que a mídia social Twitter faz parte do cotidiano dos candidatos ao principal cargo eletivo do país como uma ferramenta digital de comunicação política e eleitoral. Em junho de 2018 de acordo com o Tribunal Superior Eleitoral (TSE) o Brasil já possuía mais de 147 milhões de eleitores. Ao comparar este número com o total de seguidores de Marina Silva e Bolsonaro, que possuem mais de um milhão de seguidores pode parecer uma representação muito baixa. E realmente é se compararmos com a ex-presidente Dilma Rousseff (PT) que em 2018 tinha mais de 6 milhões de seguidores no Twitter. Todavia, o Twitter demonstra-se como uma mídia social que pode não ter muita adesão dos usuários, pois a preferência pode ser por outras mídias sociais como Facebook e Instagram. Mas para os políticos que ingressam na arena eleitoral é uma ferramenta constantemente utilizada e importante para a comunicação política.

O fato de a campanha começar oficialmente dia 15 de agosto e o horário de propaganda eleitoral de veiculação posterior em relação às eleições anteriores reduzem a possibilidade para que as hashtags sejam usadas para campanha negativa. Ou seja, os candidatos não começaram (ou não intensificaram) a desconstrução da imagem dos adversários neste período específico. Todavia, para este fim as mídias sociais são usadas durante a corrida eleitoral.

\section{CONSIDERAÇõES FINAIS}

A análise sobre o uso do Twitter pelos candidatos a presidente da República nas eleições de 2018 mostrou que a mídia se apresenta como um instrumento para a comunicação política atuante durante o período.

Uma primeira conclusão mostrou que os candidatos são compelidos a usar o Twitter de modo a criar um sistema eleitoral on-line. Todos os selecionados possuíam seu perfil no Twitter; mesmo o ministro da fazenda, Henrique Meireles, criou seu perfil logo após assumir a sua pré-candidatura à presidência do Brasil.

Uma segunda conclusão mostra que, para atingir o potencial máximo de mobilização que o Twitter permite, deve-se saber o que, quando e como postar. De acordo com os dados coletados podemos presumir que um perfil com número maior de tweets e com ingresso há mais tempo na mídia social não significa que o proprietário do perfil conquiste um número maior de seguidores. Isso ficou claro no caso do perfil do Senador Álvaro Dias: identificado como a conta mais antiga e com maior número de tweets, ele tem um número menor de seguidores se comparado com os perfis de candidatos como Marina Silva, Jair Bolsonaro, Geraldo Alckmin (ver Quadro 2 e Tabela 1).

Uma terceira conclusão refere-se às estratégias adotadas no Twitter pelos candidatos. Efetuou-se o levantamento de dados de acordo com a estratégia de comunicação no Twitter, no intuito de avaliar de acordo com a posição do candidato, como mandatário ou desafiantes. Os candidatos usaram suas contas para a exortação de sua imagem e de suas propostas ou para o confronto direto com os adversários.

Foi possível identificar, a partir da categorização da hashtags, que as estratégias seguirem um padrão. Os candidatos que são oposição ao atual governo e que se colocam como desafiantes usaram o Twitter predominantemente para a construção da imagem e para mobilização e engajamento dos simpatizantes.

Vale lembrar que os resultados obtidos nesta análise representam bem o momento: o início de uma campanha. 0 desdobramento posterior desta análise servirá para verificar se o uso do Twitter ao final do primeiro turno sofreu alguma alteração e se o padrão da forma do discurso identificado nesta análise preliminar foi mantido ou foi alterado pelos candidatos.

\section{REFERÊNCIAS}

[1] Braga, Sérgio S.; França, Andressa S.; Nicolás, Alejandra Maria. (2009). Os partidos políticos brasileiros e a internet: uma avaliação dos websites dos partidos políticos do Brasil. Revista de Sociologia e Política, Curitiba, v. 17, n. 34 , p. 183-208, 2009. 
[2] Brasil. (2018) Tribunal Superior Eleitoral. TSE aprova 10 resoluções sobre regras das eleições gerais de 2018. Brasília: Tribunal Superior Eleitoral, 2017. Disponível em: <http://www.tse.jus.br/imprensa/noticiastse/2017/Dezembro/tse-aprova-10-resolucoes-sobre-regras-das-eleicoes-gerais-de-2018>. Acesso em: 18 mar.2018.

[3] Caldevilla Domínguez, David; Rodríguez Terceño, José; Barrientos Báez, Almudena. (2019): "El malestar social a través de las nuevas tecnologías: Twitter como herramienta política". Revista Latina de Comunicación Social, 74, pp. 1264 a 1290. Disponível em: <http://www.revistalatinacs.org/074paper/1383/66es.html>.

[4] Carneiro, H. S. (2012) Apresentação: rebeliões e ocupações de 2011. In: HARVEY, David et alii. Occupy. São Paulo: Boitempo.

[5] Carvalho, Cassio Stanczyk.(2013) Senadores Virtuais? Um estudo comparado sobre o perfil e uso das redes digitais pelos senadores sul-americanos e dos EUA. 2013. Curitiba. Dissertação (Mestrado em Ciência Política). Universidade Federal do Paraná, 2013.

[6] Conceição, R. C. (2017) Campanhas on-line e polarização política: o uso do Twitter nas eleições presidenciais brasileiras de 2014. In: VII Congresso da Associação Brasileira de Pesquisadores em Comunicação e Política (VII COMPOLÍTICA), realizado na Universidade Federal do Rio Grande do Sul (UFRGS), de 10 a 12 de maio de 2017.

[7] Datafolha. (2018) Governo Temer é reprovado por 70\%. São Paulo: Instituto de Pesquisas Datafolha, 2018. Disponível em: <http://datafolha.folha.uol.com.br/opiniaopublica/2018/01/1954759-governo-temer-e-reprovadopor-70.shtml>. Acesso em: 18 mar.2018.

[8] Habermas, J. (2014) Mudança estrutural da esfera pública: investigação sobre uma categoria da sociedade burguesa. São Paulo: Unesp.

[9] Habermas, J. (2006) Political Communication in Media Society: Does Democracy Still Enjoy An Epistemic Dimension? The Impact of Normative Theory on Empirical Research. Communication Theory, v. 16, n. 4, p. 411-426.

[10] Herman, F. (2017) Campanha eleitoral no Twitter: as estratégias dos candidatos na disputa para a Prefeitura de Curitiba em 2016. Revista Eletrônica de Ciência Política, Curitiba, v. 8, n. 3, p. 139-164, 2017. Disponível em: <http://dx.doi.org/10.5380/recp.v8i3.54819>. Acesso em: 18 mar.2018.

[11] Lima, V. A. (2004) Sete teses sobre mídia e política no Brasil. Revista USP, São Paulo, n. 61, p. 48-57, mar.maio. 2004. Disponível em: <https://www.revistas.usp.br/revusp/article/view/13317>. Acesso em: 18 mar.2018.

[12] Manin, B. (1995). As metamorfoses do governo representativo. Revista Brasileira de Ciências Sociais, São Paulo, v. $10, \quad$ n. $29, \quad$ p. $5-34, \quad 1995 . \quad$ Disponível <http://www.anpocs.org.br/portal/publicacoes/rbcs_00_29/rbcs29_01>. Acesso em: 18 mar.2018.

[13] Marques, F. P. J. (2018) a. Democracia on-line e o problema da exclusão digital. Intexto, Porto Alegre, v. 30, p. 93-113, jul.2014. Disponível em: <http://seer.ufrgs.br/index.php/intexto/article/view/41269/30388>. Acesso em 16 mar.2018.

[14] Moraes, T. P. B.; Santos, R. M. (2016). Do \#ForaDilma ao \#ForaTemer - as duas faces antagônicas de Jano. Pauta Geral - Estudos em Jornalismo, v. 3, n. 2, p. 66-82. Disponível em: https://www.revistas2.uepg.br/index.php/pauta/article/view/9296 .

[15] Recuero, R. (2014) 0 Twitter como esfera pública: como foram descritos os candidatos durante os debates presidenciais do 2o turno de 2014? Revista Brasileira de Linguística Aplicada, Belo Horizonte, v. 16, n. 1, p. 157-180, mar.2016. Disponível em: <http://www.scielo.br/pdf/rbla/v16n1/1984-6398-rbla-16-01-00157.pdf>. Acesso em 16 mar.2018.

[16] Rossetto, G.; Carreira, R.; Almada, M. P. (2013) Twitter e comunicação política: limites e possibilidades. Revista Compolítica, Rio de Janeiro, v. 3, n. 2, p. 189-216, jul.-dez. 2013. Disponível em: <http://compolitica.org/revista/index.php/revista/article/view/49/51>. Acesso em 16 mar.2018.

[17] Sanchez, A.; Granado. A; Antunes, J. B. (2014). Redes Sociais para Cientistas. Lisboa: Nova Escola Doutoral Reitoria da Universidade NOVA de Lisboa.

[18] Stromer-Galley, Jennifer. (2013) Interação online e por que os candidatos a evitam. In: MARQUES, Francisco P. J. A.; SAMPAIO, Rafael; AGGIO, Camilo (orgs.). Do clique à urna: internet, redes sociais e eleições no Brasil. Salvador: UFBA, 2013

[19] Thompson, J. B. (2002) O escândalo político: poder e visibilidade na era da mídia. Petrópolis: Vozes.

[20] Twitonomy. (2018) Disponível em: <http://www.twitonomy.com>. Acesso em: 18 mar.2018.

[21] Twitter. (2018) Investor Relations. San Francisco: Twitter. Disponível em: <https://investor.twitterinc.com>. Acesso em: 18 mar.2018 


\title{
Capítulo 2
}

As chacinas no Rio Grande do Norte em 2017:

Consequências da ausência do Estado*

\author{
Ivenio do Espirito Santo Hermes Júnior \\ Thadeu de Sousa Brandão \\ Iara Mariana de Farias Nóbrega \\ Cindy Damaris Gomes Lira
}

Resumo: Objetivo: apresentar o modus operandis que processam as chacinas registradas no Rio Grande do Norte entre o período de janeiro a setembro de 2017. Método: abordagem quali-quantitativa, trata-se de um relatório categórico, ou seja, uma análise a chacinas ocorridas no Rio Grande do Norte - RN, em que utilizou-se consubstancial a plataforma multifonte do Observatório de Violência Letal Intencional do RN. Resultados: apontam que praticamente, em quase todos os meses, com exceção de abril, junho e agosto, houveram execuções sob a forma de chacinas, maioria aconteceram na Região Metropolitana de Natal, apontando para a lógica da desestrutura da Segurança Pública (ostensiva e investigativa), além do raio de ação dos grupos criminosos implicados na prática em atuar nos espaços com maior grau de desestruturação e menor de ação estatal. Conclusão: É perceptível que a ausência do Estado como protagonista real da segurança pública tem sido o responsável maior pela crescente elevação em eventos criminais de todos os tipos no RN. As chacinas, que são fenômeno constante na histórica impunidade e violência brasileira, estão tornando-se quase que corriqueiras no estado do RN.

Palavras-chave: Conduta Violenta Letal Intencional; Chacina; Homicídio. 


\section{INTRODUÇÃO}

A formatação da violência vem sendo apresentada em diferentes perspectivas que variam de acordo como as gestões públicas desejam que o público tenha acesso ao prisma de criminalidade. Nesse contexto, o OBVIO - Observatório da Violência Letal Intencional, Grupo de Pesquisa da Universidade Federal Rural do Semi-Árido (UFERSA), que funciona como instituto de pesquisa científica associado ao Ministério Público do Rio Grande do Norte, à Assembleia Legislativa do Rio Grande do Norte e ao Conselho Estadual dos Direitos Humanos e da Cidadania, cadastrado no CNPQ (http://bit.ly/OBVIO-CNPQ) com técnicos, pesquisadores e estudantes de várias instituições de nível superior do Rio Grande do Norte, vem se posicionando de forma esclarecedora quanto aos problemas de violência.

Com duas chacinas ocorridas em 2015, duas em 2016 e sem histórico rastreável e com validade científica dessa classificação de atividade criminosa letal nos anos anteriores, 2017 certamente entrará para a história com mais uma referência negativa para o Rio Grande do Norte: 12 chacinas registradas no transcurso de apenas 9 meses.

A mídia e organizações da sociedade civil têm questionado este Observatório a partir de quantos assassinatos o termo "chacina" seria aplicável, ao mesmo tempo, para responder a essa questão e objetivando traçar melhores vetores de compreensão sobre a insegurança pública, diante desse quadro de frequência desse tipo de ação criminosa, esse estudo foi produzido para nortear futuros mapeamentos.

Para tanto, as informações apresentadas são oriundas de dados interpolados por meio da Metodologia Metadados $^{5}$, no âmbito do Grupo de Pesquisas Criminais da UFERSA, não pretendendo substituir a responsabilidade do estado para com a transparência e nem quanto à prestação de serviços para ações policiais.

O Banco de Dados do OBVIO - Observatório da Violência Letal Intencional é obtido por meio do tratamento parametrizado de dados de diversas fontes ${ }^{6}$, numa metodologia de pesquisa denominado Plataforma Multifonte criado por Hermes e Dionisio7. Seus conceitos e diagnósticos são determinadas por análises contextuais de complexidade, fundamentadas na Teoria da Complexidade de Edgar Morin, citado por Santos, Santos e Chiquieri8, concatenando conhecimentos de saberes diversos de forma dinâmica e integrada para a celeridade e a devida credibilidade dos resultados.

\section{CONCEITUANDO E ATUALIZANDO}

Conhecida como sendo uma matança de várias pessoas em grupo, ou reunidas em um determinado local, o termo "chacina" é usado para diferenciar um assassinato violento dos demais crimes de homicídio.

Chacinar, em sua terminologia é o verbo para ação de preparar e salgar a carne. Originalmente, o termo chacina vem do latim siccina, que significa carne seca, empregado para se referir ao abate de bois e porcos, que eram cortados em pedaços, separando as partes para o processo de salgar ou curar, e assim conservar a carne por mais tempo, possibilitado seu consumo muito tempo depois da morte dos animais.

Ao adaptar o termo para a morte de seres humanos provocada pelo animus assassino de outro ou outros seres humanos, essa matança tem o simbolismo de uma prática violenta, recebendo o entendimento de que sua aplicação se aplica a partir de três homicídios no mesmo local e hora.

Num complemento da ideia original para o termo chacina, o substantivo feminino de nossa gramática é usado para se referir ao assassinato de muitas pessoas, ao mesmo tempo, de modo intenso e brutal, provocando comoção social, resgatando o termo original do abate de animais em métodos que envolviam

\footnotetext{
5 HERMES, Ivenio; DIONISIO, Marcos. Do Homicímetro Ao Cvlimetro: A Plataforma Multifonte e a Contribuição Social nas Políticas Públicas de Segurança. 2. ed. Natal: Saraiva, 2014. 110 p.

6 ITEP - Instituto Técnico-Científico de Perícia, MPRN - Ministério Público do Rio Grande do Norte por meio do (CAOP Criminal - Centro de Apoio Operacional das Promotorias Criminais e GAECO - Grupo de Atuação Especial de Combate ao Crime Organizado, PCRN - Polícia Civil do RN, PMRN - Polícia Militar do RN, DATASUS - Departamento de Informática do SUS (Informações de Óbitos e de Entradas de Pessoas Feridas por Causas Externas), Sistema de Pesquisa Social e Mídias do OBVIO/UFERSA, etc.

7 HERMES, Ivenio. Metadados 2013: Análises da Violência Letal Intencional no Rio Grande do Norte. 2. ed. Natal: Saraiva, 2014.145 p.

8 SANTOS, Akiko; SANTOS, Ana Cristina Souza dos; CHIQUIERI, Ana Maria Crepaldi. A Dialógica de Edgar Morin e o Terceiro Incluído de Basarab Nicolescu: Uma Nova Maneira de Olhar e Interagir com o Mundo. III Edipe: Encontro Estadual de Didática e Prática de Ensino, Rio de Janeiro, v. 1, n. 1, p.1-26, 2 out. 2009.
} 
sempre muita violência, já que para facilitar a salga seus corpos eram desmembrados e reduzidos a pedaços.

Se tratássemos todas a mortes bárbaras dentro dos conceitos de chacina acima expostos, as mortes matadas no Rio Grande do Norte sob esse espectro de ação, elevaríamos o número de chacinas ocorridas no estado em 2017, num risco de banalizar a violência já tão banalizada, apresentando um nível de barbárie muito mais elevada do que a que já temos.

Por outro lado, não classificaríamos apropriadamente crimes sequenciais, que ocorrem em lugares próximos e cujas mortes guardem relação entre si, deixando de mapear eventos criminais que poderiam reunir elementos para estudos posteriores e até investigações mais direcionadas, como faz a Divisão de Homicídios do Estado de São Paulo, que possui equipe especializada para a investigação de homicídios múltiplos.

Portanto, para nosso estudo e doravante, até que surja uma definição mais apropriada, adotaremos o seguinte conceito:

Chacina é a matança de diversas pessoas em curto intervalo de tempo, em locais muito próximos e seguindo o mesmo modus operandis, podendo variar a localização se houver uma motivação ou ação determinante, ou seja, crimes que se estabeleça um nexo causal e temporal de similitude.

\section{METODOLOGIA}

Esse trabalho tem uma abordagem quali-quantitativa, trata-se de um relatório categórico, ou seja, uma análise a chacinas ocorridas no Rio Grande do Norte - RN, em que utilizou-se consubstancialmente a plataforma multifonte do Observatório de Violência Letal Intencional do RN. Esse recurso metodológico, é uma variação da metodologia de pesquisa já conhecida, mas que se utiliza de outros atores da sociedade civil para enriquecer, acelerar a obtenção de dados e comprovar o acontecimento de crimes contra a vida.

A Plataforma Multifonte conta com uma gama substancial de atores que foram denominados de Fontes Sociais, que vão desde sites fidedignos de informações sobre condutas violentas letais intencionais, a dados compartilhados de instituições representantes de Segurança Pública. Com uma sistemática de interpolação, parametrização e consolidação, mensalmente gera resultados referentes a violência letal intencional em todo território potiguar.

O recurso supracitado atrelado a análise metadados, configuram-se como uma Metodologia de Contagem de Crimes Violentos Letais Intencionais, uma Comunicação Institucional orientada pela SENASP à Secretaria da Segurança e da Defesa Social de João Pessoa, de onde se extrai ipsis litteris: "A sigla CVLI foi criada em 2006 pela Secretaria Nacional de Segurança Pública (Senasp), vinculada ao Ministério da Justiça (MJ), com a finalidade de agregar os crimes de maior relevância social, pois além do homicídio doloso outros crimes também devem ser contabilizados nas estatísticas referentes a mortes"(HERMES; DIONÍSIO, 2014, p.48).

Além desse entendimento de CVLI, objetivando não imputar a palavra ou a denominação de "crime" para casos ainda não julgados e devidamente classificados pela autoridade policial e judiciária, a significação dessa sigla foi ampliada por Hermes (2015) dando a ela o seguinte texto:

C V L I é uma conduta violenta letal intencional que resume toda ação humana que visa a atingir fisicamente a outro, produzindo morte como resultado final imediato ou posterior em decorrência da natureza do ferimento causado, em virtude de ação e/ou omissão.

Destarte, a Plataforma Multifonte se "utiliza de conceitos elevados de contribuição eivada na busca pela paz, tendo em vista seu uso como ferramenta para a geração de um banco de dados acessível, ágil e confiável. Sob a diretriz da integração em busca da paz, a contribuição social para a segurança pública inserida na Plataforma Multifonte, se recria e processa uma nova metodologia que está além de nomenclaturas. Ela pretende manter estatísticas atuais, que gerem substância para as boas práticas de segurança pública, que valorizem a vida, e é a vida que se deseja permanentemente proteger" (HERMES; DIONÍSIO, 2014, p.68). 


\section{RESULTADOS E DISCUSSÕES}

Na modelagem que adotamos para o presente estudo, agrupamos os crimes em dois recortes: um tratando do número de eventos e outro relacionado ao número de vítimas decorrentes destas ações.

O gráfico a seguir aponta a absoluta aleatoriedade temporal das chacinas ocorridas no RN.

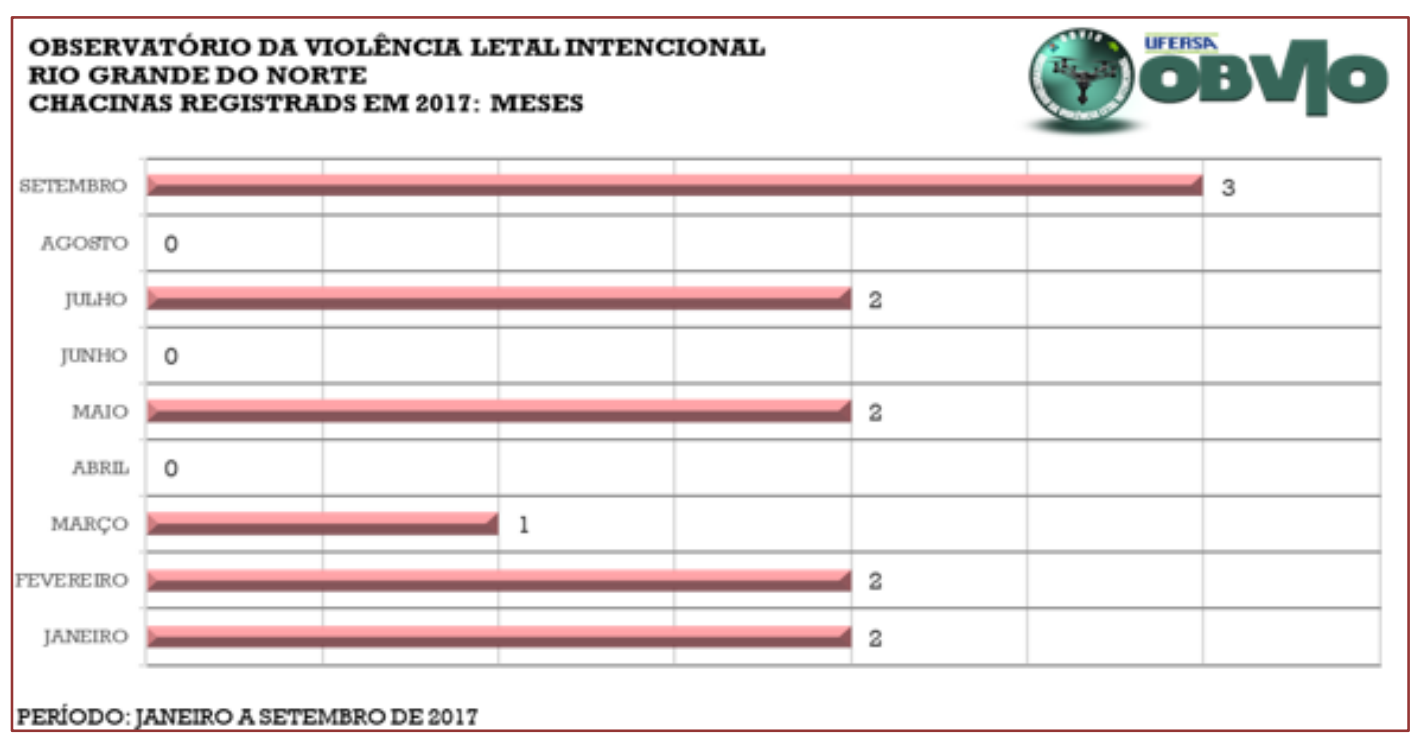

Praticamente, em quase todos os meses, com exceção de abril, junho e agosto, houveram execuções sob a forma de chacinas, apontando a continuidade deste tipo de prática homicida, mas sem seguir um padrão temporal ainda detectável.

\begin{tabular}{|c|c|c|c|}
\hline \multicolumn{4}{|c|}{ CHACINAS NORUO GRANDE DONORIE EM2017 } \\
\hline \begin{tabular}{|l|l|} 
R & DATIA \\
\end{tabular} & LOCAUDADEI BAIRRO & MNIĆ́PIO & TERPIORA'UDADE \\
\hline $114 / 01 / 2017$ & ALCACZ & NSARCPESTA & FEGAOMEIRCPOITANA \\
\hline $217 / 01 / 2017$ & BAFEÃO & CEARÁMRM & FEGAOMEIRCFOITANA \\
\hline $303 / 02 / 2017$ & PAADETOROS & TAROS & INIERCR \\
\hline 4 21/02/2017 & BAXADORATO & CEARÁMAM & FEGAOMEIRCPOITANA \\
\hline 5 11/03/2017 & BOAUSTA & MOSSCFO & INIEPCR \\
\hline $\begin{array}{ll}6 & 16 / 05 / 2017\end{array}$ & MLAPARÁ & S्FPADOMM & INIEPCR \\
\hline 7 23/05/2017 & NOAPAFNAMRM & PAPNAMRM & FEGAOMEIRCPOITANA \\
\hline $817 / 07 / 2017$ & CANTODEMDOSA & 旧MDMAFNHO & REGAOMEIRCPOUTANA \\
\hline $929 / 07 / 2017$ & FEDHANOA & EXTREMCZ & REGAOMEIRCPOITANA \\
\hline 10 22/09/2017 & SANTAMARA & EXTREMCZ & FEGAOMEIROPOITANA \\
\hline $1127 / 09 / 2017$ & ROCAS & NATAL & REGAOMEIRCPOUTANA \\
\hline 12 28/09/2017 & QULOMBODOS PALMAES & MACABA & REGAOMEIRCPOUTANA \\
\hline
\end{tabular}

Excetuando-se a primeira e mais brutal chacina - ocorrida na Penitenciária de Alcaçuz em janeiro, pautada por um contexto específico de absoluta perda de controle daquela instituição penal e de conflagração aberta de duas redes (facções) criminosas que ali disputavam sua hegemonia - as demais se distribuem nas mais variadas localidades, todas seguindo um padrão específico: são Zonas Rurais ou Periferias Urbanas. 
O evento de Alcaçuz talvez seja aquele onde a ausência do estado é mais sensível do ponto de vista público, nele, todas as formas de poder sobre uma população (a carcerária) que deveria estar sobre o absoluto controle das forças de segurança, se mostraram ineficazes ou ausente para o público mundial, que viu o Rio Grande do Norte se tornar exemplo de erros que não devem ser cometidos por nenhuma gestão que se autoproclame como Governo da Segurança.

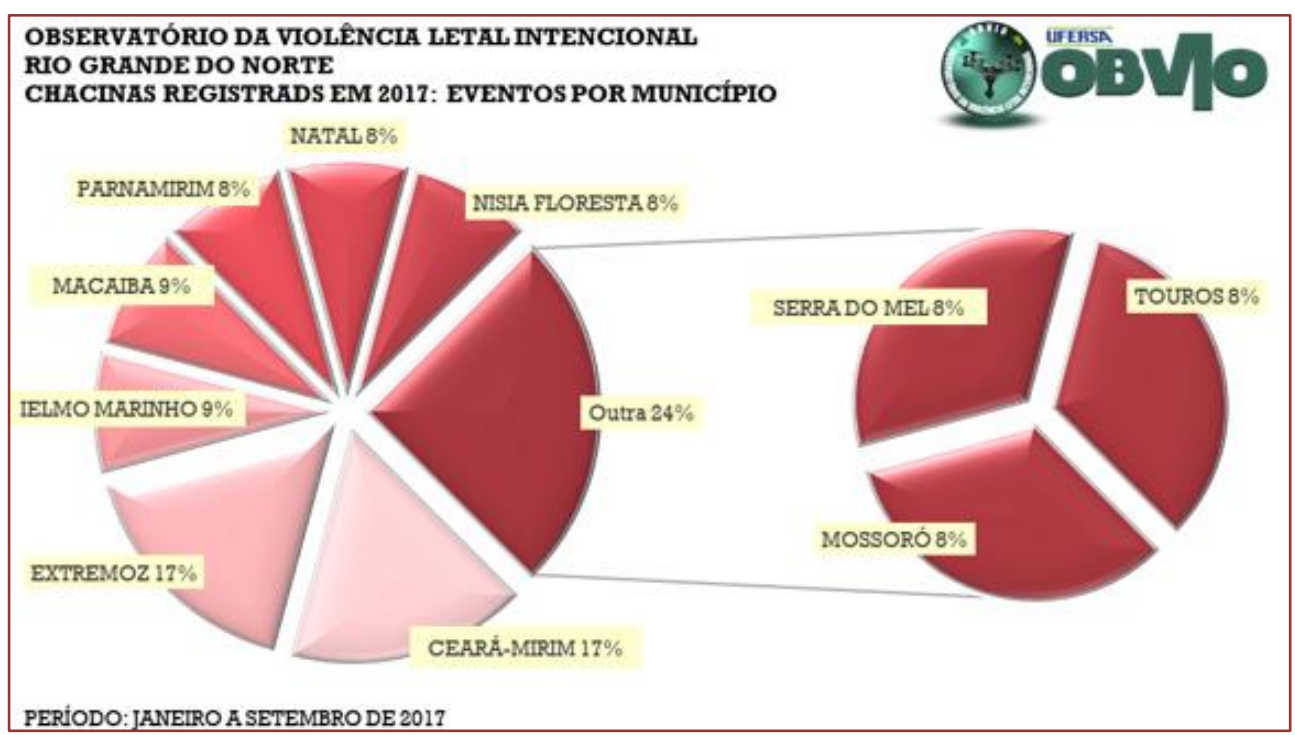

Localizadas em sua maioria na Região Metropolitana de Natal (9 de 12), os eventos criminais denominados chacinas apontam para a lógica da desestrutura da Segurança Pública (ostensiva e investigativa), além do raio de ação dos grupos criminosos implicados na prática em atuar nos espaços com maior grau de desestruturação e menor de ação estatal.

As energias policiais, ou seja, de ações de segurança pública ostensivas, preventivas e investigativas, se concentraram em determinados pontos focais, onde se concentram demandas midiáticas e do poder financeiro de algumas elites, sem, contudo, observarem a expansão da criminalidade ou o efeito migratório que políticas concentradoras podem gerar no mapa do crime.

Notemos as políticas e ações direcionadas do Estado:

- $\quad$ Ronda Cidadã: Criada em julho de 2015, visou os bairros de Mãe Luiza, Areia Preta e Petrópolis, direcionando efetivo policial para tornar Mãe Luíza um bairro seguro e reduzir assim a suscetibilidade dos bairros de elite com os quais fazia linde. 0 modelo se tornou ineficaz antes mesmo de completar um ano de sua implantação, primeiro porque não vinha acompanhado de políticas sociais, uma vez que o que se pretendia não era aumentar a segurança da população pobre, e sim isolá-la da população rica em seus derredores, e ainda assim, mostrando sinais de ineficácia, foi também implantado no bairro Planalto em outubro de 2015 e em alguns bairros de Mossoró em 2017;

- AISPS - Áreas Integradas de Segurança Pública: Modelo de redistribuição de forças policiais estaduais que, em tese, integraria as Polícias Civil e Militar num modelo integrado de planejamento e execução de ações policiais. 0 projeto não dialogou com as necessidades de cada força policial, não levou em consideração as realidades e necessidades das populações dos bairros, realocando delegacias para o atendimento de pessoas de locais distantes, gerando um subregistro de crimes que, em princípio, aparentou ser uma redução de ações criminais, mas que não passou da falta de vontade e disponibilidade da população de se deslocar para outros bairros para registrar ocorrências; 
- PLANESP - Plano Estadual de Segurança Pública: Trata-se de um grande sofisma que não integra ações entre as secretarias de estado, não prevê verba concretas e existente para a execução dos planos e não cria liame entre as ações de segurança das duas secretarias responsáveis pela segurança: a SESED e a SEJUC;

- Operações Saturação: São ações de policiamento que visa saturar com policiamento ostensivo e investigação áreas pré mapeadas que se encontrem em situação de suscetibilidade. 0 modelo perdeu o foco quando passou a ser utilizado apenas para responder demandas geradas pelos políticos e pelo clamor público, sendo uma forma de a gestão de segurança mostrar que estava trabalhando direcionando ações para o foco da mídia e não para ações estudadas e planejadas.

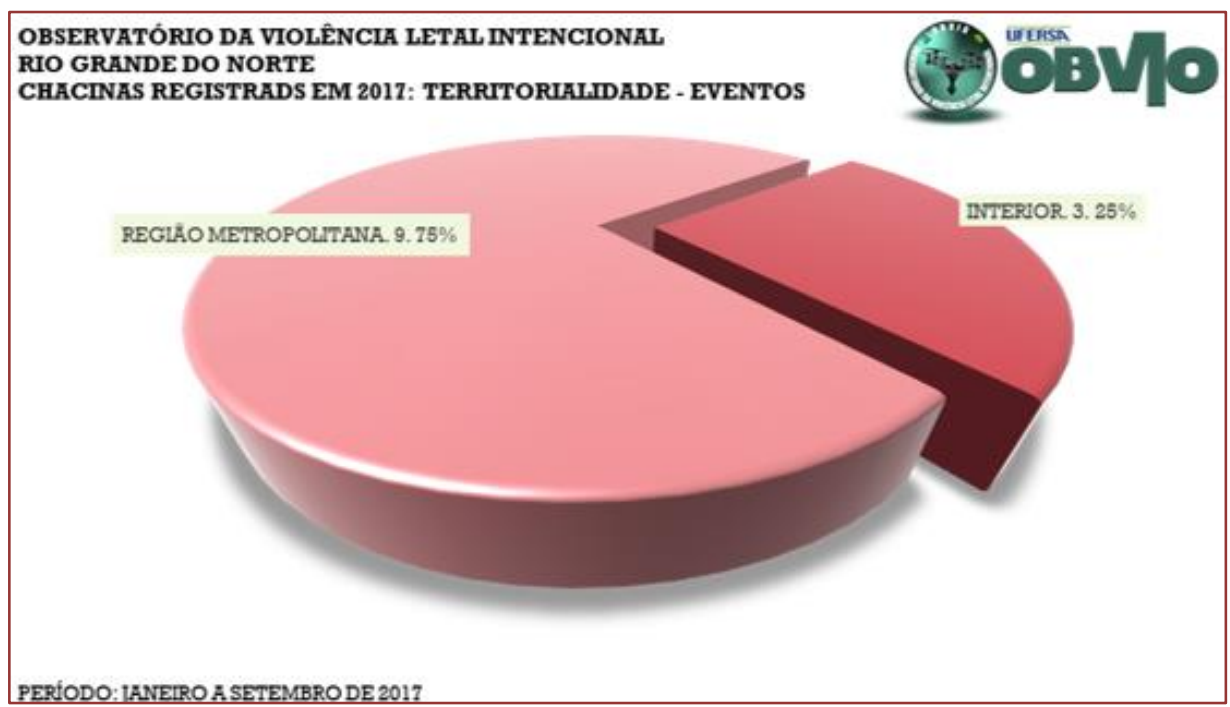

Por isso as ações e planos acima expostos apenas provocaram o efeito migratório e concentrador das ações criminosas, que levaram ao acontecimento de chacinas justamente nas lacunas deixadas por essas ações.

Seguindo o mesmo viés analítico, mesmo quando ocorrida em Natal (1 caso), a mesma se dá em bairro periférico, com uma variabilidade assustadora: não se reproduz (até agora) em nenhuma localidade, se ramificando por vários municípios ainda não atingidos. Esse é um claro efeito da concentração não estudada das variações do padrão de ocorrências criminais. Ou seja, nas áreas onde havia operação saturação ou ronda cidadã, se criava um bolsão temporário de segurança, enquanto noutras, se provocava o recrudescimento do crime e ações retaliadoras de grupos criminosos.

A Região Metropolitana de Natal, em sua parte urbana mais privilegiada, e as cidades de Natal, Parnamirim e Mossoró, também em áreas escolhidas sob um poder discricionário não pautado em estudos científicos, mal conseguiu dar resposta às ações criminais em sua área de abrangência, e o resultado foi a promoção de uma cadeia de crimes na forma de duplos e triplos homicídios, mortes de jovens e de mulheres, de pessoas moradoras de periferias que aos poucos se tornaram palco propício para as chacinas. 
VÍTIMAS

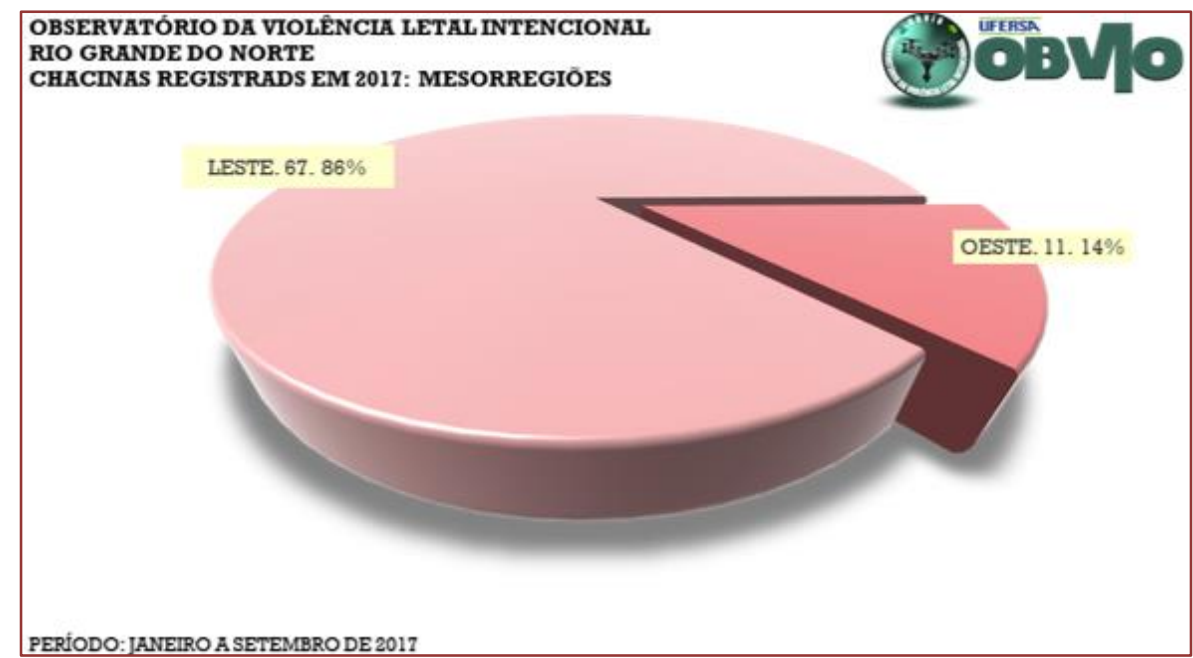

Seguindo o padrão dos CVLIs individuais, a maior parte das vítimas das chacinas se encontram na Região Leste. 67 delas - 86\% do total - foram chacinadas nessa Região, enquanto 11 delas foram na Região Oeste ( $14 \%$ do total). Importa apontar a relação - até agora contingente - entre as chacinas e os núcleos urbanos "metropolitanos" (Natal e Mossoró), já que todas as chacinas - como até agora quase a totalidade dos CVLIs - ocorrem na área circunspecta de suas "áreas metropolitanas".

0 padrão geográfico observado nos locais onde ocorrem as chacinas coincidem com os locais onde a presença efetiva de ações policiais é extremamente marginal e ocasional, sugerindo que as ocorrências se proliferam de acordo com as lacunas deixadas pelas políticas públicas, que de ineficazes, liberam espaço para a proliferação de eventos criminosos de grande conotação.

Os crimes contra o patrimônio e as ações que visam prender sujeitos que pertencem à base do tráfico de drogas, não visam a redução de homicídios, que são o principal sintoma da perda de qualidade de vida da população, e portanto apenas deixam livre no caminho da impunidade aqueles que cometem crimes contra a vida.

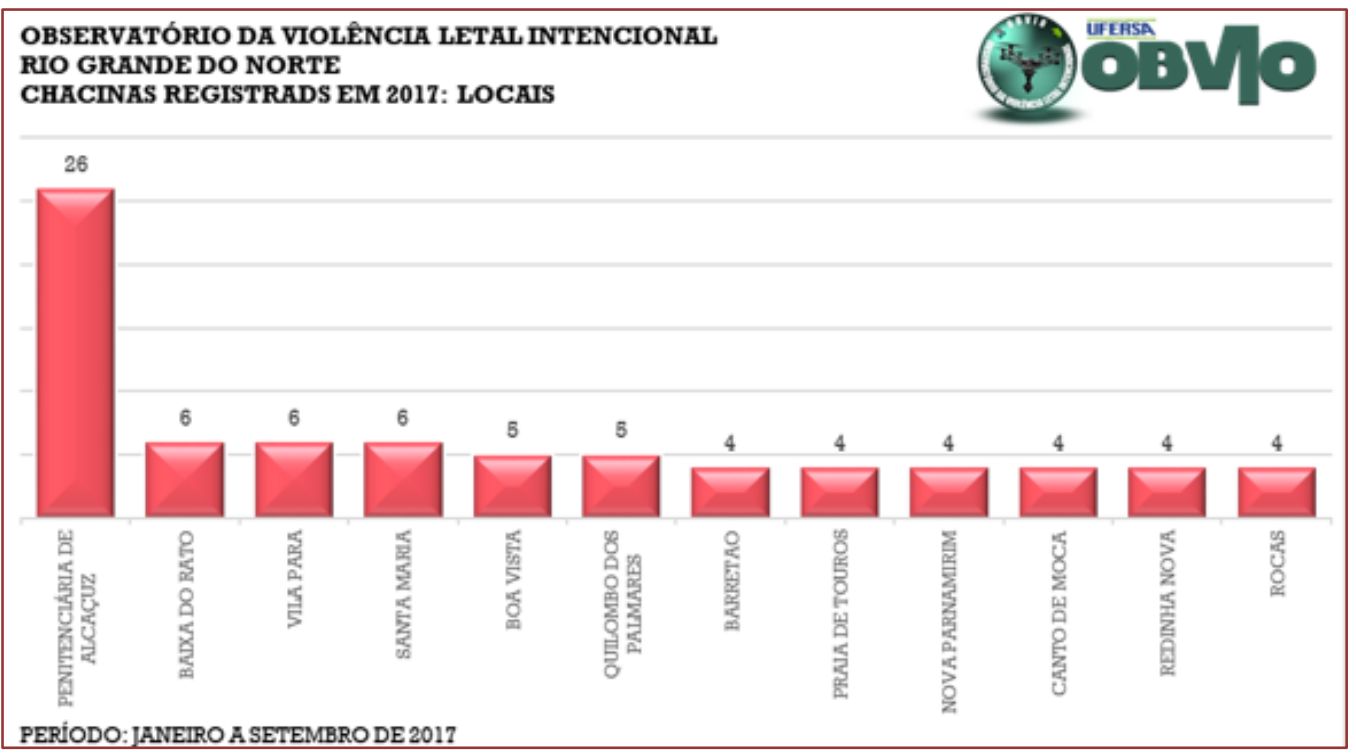




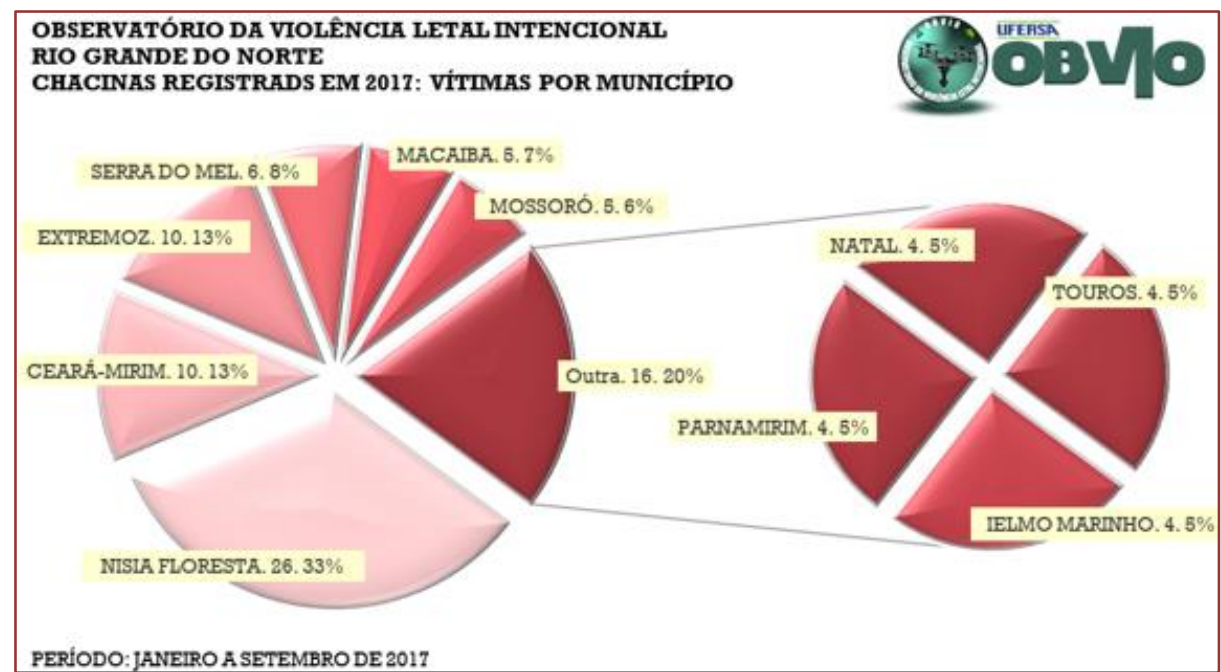

Com exceção da Chacina ocorrida em janeiro na Penitenciária de Alcaçuz, onde foram vitimadas 26 pessoas (dados até agora verificados), as demais se distribuem em ocorrências com 6 a 4 vítimas, em várias localidades rurais e periféricas. A única exceção (tratada com cautela) é o bairro de "Boa Vista" em Mossoró, bastante urbanizado, mas com características de periferia urbana.

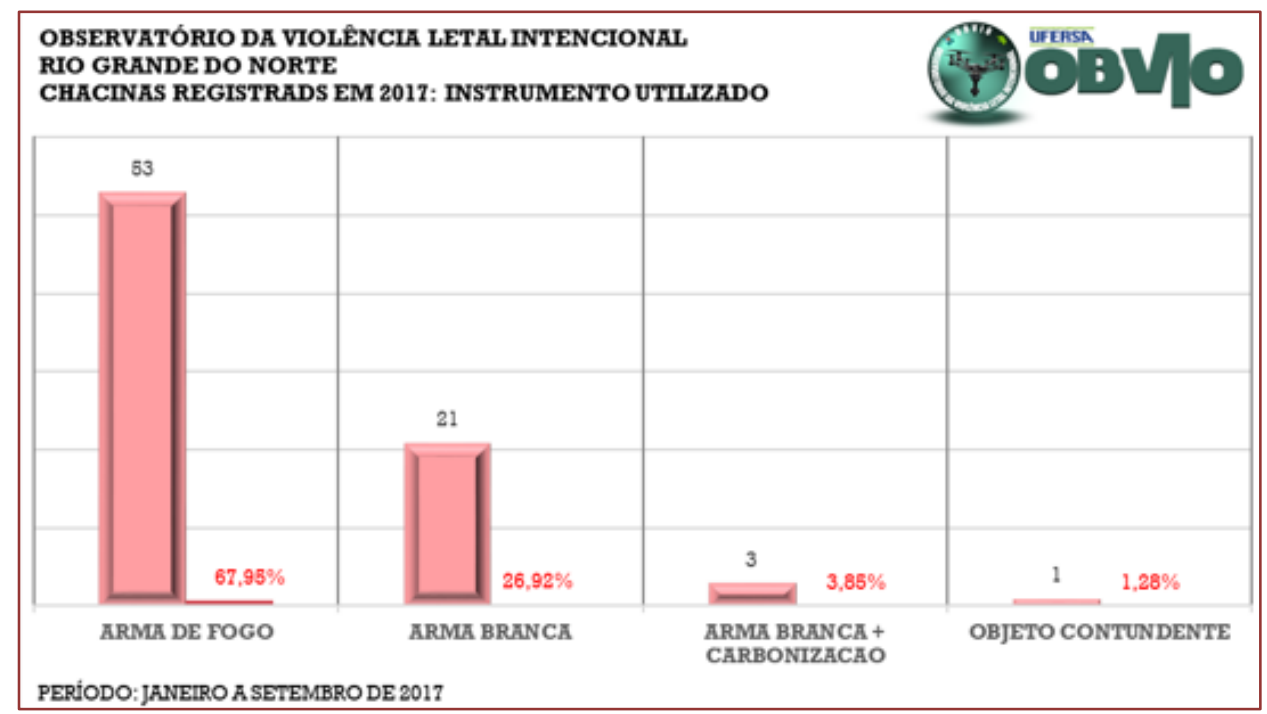

Os municípios onde ocorreram as chacinas, seguindo a lógica analítica já esboçada, foram: Nísia Floresta (26 CVLIs, 33\% do total), Ceará-Mirim e Extremoz (10 CVLIs, 13\% do total cada), Serra do Mel (6 CVLIs, $8 \%$ do total), Macaíba e Mossoró (5 CVLIs, 6\% do total cada, Natal, Parnamirim, Touros e Ielmo Marinho (4 CVLIs, $5 \%$ do total cada). 


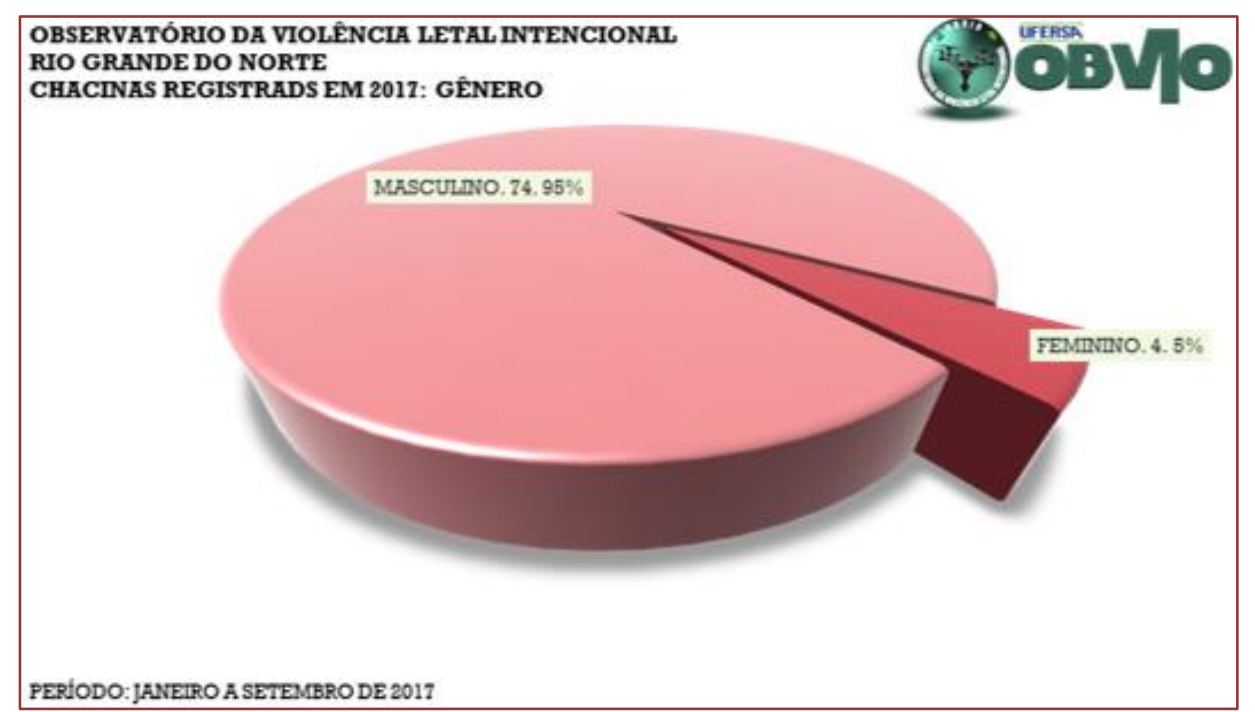

Com exceção (novamente) de Alcaçuz, as chacinas ocorridas em 2017 no RN foram perpetradas com uso de arma de fogo (53 CVLIs, 63\% do total). Dada as características deste tipo de conduta violenta letal intencional, a quantidade de vítimas e o modus operandi, a arma de fogo é quase sempre o instrumento usual. Alcaçuz, conforme estudo já publicado por este Observatório, seguiu instrumentação diferente.

Quanto ao gênero das vítimas, 74 delas (95\%) eram homens e 4 delas (5\%) eram mulheres. Seguindo o perfil das vítimas de CVLIs neste quesito.

Desses quadros apresentados percebemos que as políticas públicas direcionadas para a redução dos homicídios no Rio Grande do Norte não têm resultado efetivo porque não admitem o planejamento estratégico e integrado de ações policiais. Elas não consideram os contextos urbanos em seus múltiplos aspectos, fazendo com que ações operacionais pontuais provoquem a migração criminal, gerando um falso indicador de redução da violência em uma área sendo que em outras ele aumenta;

As ações atividades de policiamento sem o estudo preditivo de eventos criminais, gera um bolsão de retenção da atividade criminosa, que após cessar suas atividades eclode em grande violência.

O número de homicídios no Rio Grande do Norte atingiu a marca de 2050 no final de outubro, ou seja, 25\% a mais que em 2016.

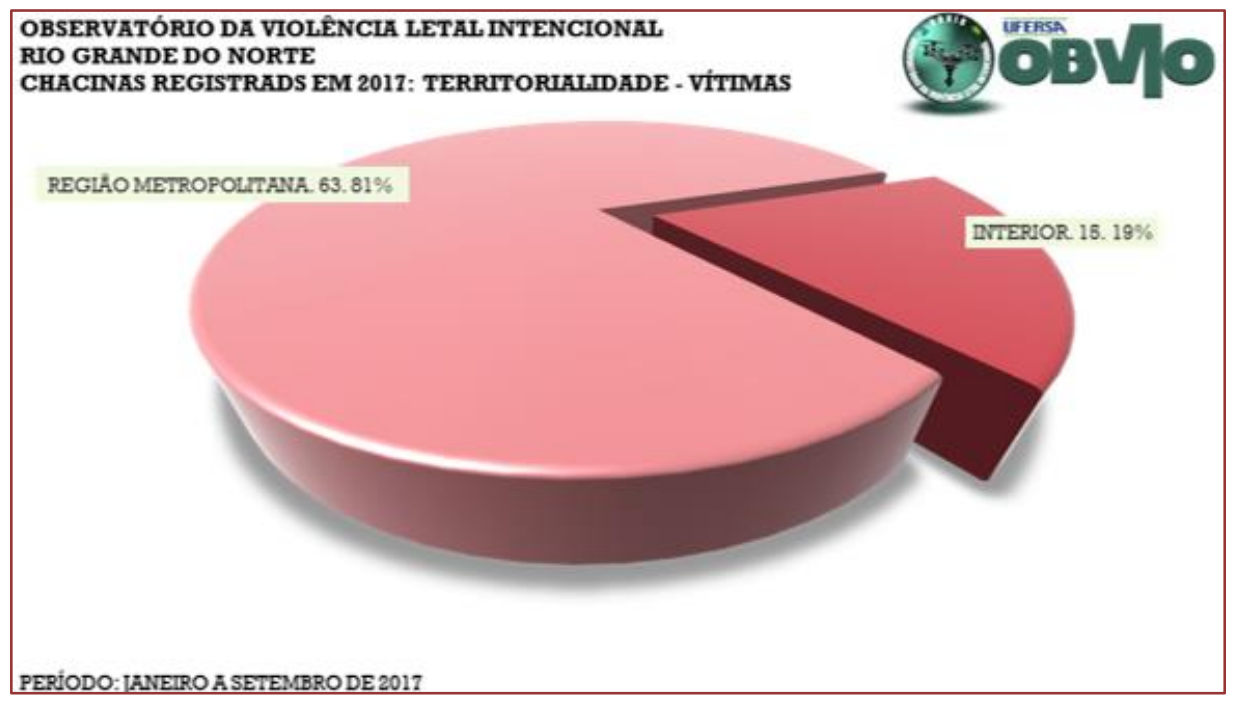




\section{CONSIDERAÇÕES FINAIS}

Perceptível que a ausência do Estado como protagonista real da segurança pública tem sido o responsável maior pela crescente elevação em eventos criminais de todos os tipos no RN, propiciando o "lugar perfeito" para o acontecimento do fenômeno de ocupação desses espaços ociosos, onde os criminosos passam a determinar como a realidade cotidiana deve ser percebida pela população dos bairros e outros locais onde prevalece o domínio dos criminosos, adaptando-a ao seu sistema próprio de valores.

É notória a falha das políticas públicas direcionadas para a redução dos homicídios, a falta de planejamento estratégico e integrado de ações policiais, e dentro desse parco direcionamento de ações que possa existir, não existe respeito aos contextos urbanos em seus múltiplos aspectos e realidades contextuais e locais. 0 desinteresse em aferir resultados na redução de homicídios clareia a percepção de que há somente preocupação em combater crimes contra o patrimônio (pois esta prática atende às demandas das classes abastadas) e o tráfico de drogas (pois estes dão maior visibilidade e perspectiva de geração futura de votos) e faz com que ações operacionais pontuais provoquem a migração criminal, gerando um falso indicador de redução da violência em uma área sendo que em outras ele aumenta;

0 estudo preditivo de eventos criminais para gerar decisões quanto à escolha adequada de locais para ações de policiamento, cria um ovo de serpente de retenção da atividade criminosa, que espera para eclodir sempre que cessar suas atividades, e quando isso acontece, o faz em grande violência;

As chacinas, que são fenômeno constante na histórica impunidade e violência brasileira, estão tornando-se quase que corriqueiras no estado do RN. Além da impunidade absolutamente perceptível neste tipo de crime (investigativa e juridicamente falando), as ações constantes apontam para uma prática repetida que, não cessando, levará as taxas de CVLIs a novos patamares nunca vistos. 0 perfil das vítimas segue o mesmo dos demais CVLIs: homens, jovens, pardos e negros, moradores de periferias e com baixa escolaridade e renda. A indiferença dos poderes constituídos e da própria sociedade, que alimenta o discurso falacioso da justificativa vitimológica do "envolvimento no tráfico, etc." como "justificativa" das mortes, alimentam esse crescimento, inexoravelmente.

As chacinas são apenas o agravamento do quadro de insegurança e de vulnerabilidade a que são submetidos essa parcela da população. 0 número de homicídios no Rio Grande do Norte atingiu a marca de 2050 no final de outubro, ou seja, 25\% a mais que em 2016, e esse quadro é agravado - até onde as investigações realizadas permitem observar - pela ação de grupos "semi-organizados" em práticas de extermínio. Tudo isso, como dissemos, com o arbítrio contumaz do Estado e da Sociedade.

\section{REFERÊNCIAS}

[1] Alvarenga Filho, José Rodrigues. A “Chacina do Pan” e a produção de vidas descartáveis. IN: Fractal: Revista de Psicologia, v. 28, n. 1, p. 111-117, jan. -abr. 2016.

[2] Hermes, Ivenio. Metadados 2013: Análises da Violência Letal Intencional no Rio Grande do Norte. 2. ed. Natal: Saraiva, 2014. 145 p.

[3] Hermes, Ivenio; Dionisio, Marcos. Do Homicímetro Ao Cvlimetro: A Plataforma Multifonte e a Contribuição Social nas Políticas Públicas de Segurança. 2. ed. Natal: Saraiva, 2014. 110 p.

[4] Hermes, Ivenio. Juventude Potiguar. 2. ed. Natal: Clube de Autores, 2015. 120 p.

[5] Porchat, Maria Elisa. A Palavra Chacina. In Língua Falada. Disponível em: < https://mariaelisaporchat.com/2013/05/07/a-palavra-chacina >. Publicado em 7 mai. 2013 e acesso em: 28 set. 2017.

[6] Santos, Akiko; Santos, Ana Cristina Souza dos; Chiquieri, Ana Maria Crepaldi. A Dialógica de Edgar Morin e o Terceiro Incluído de Basarab Nicolescu: Uma Nova Maneira de Olhar e Interagir com o Mundo. III Edipe: Encontro Estadual de Didática e Prática de Ensino, Rio de Janeiro, v. 1, n. 1, p.1-26, 2 out. 2009.

[7] Significados BR. Significado de Chacina. Disponível em: < https://www.significadosbr.com.br/chacina >. Acesso em: 28 set. 2017.

[8] Siqueira, Raíza, Landim, Leilla. Trajetos da Violência, da Segurança Pública e da Sociedade Civil na Cidade do Rio de Janeiro. Brasília: IPEA, 2013. 


\section{Capítulo 3}

\section{O Estado Inconstitucional das coisas na Saúde da Penitenciária Agrícola do Monte Cristo}

\section{Nathalie de Azevedo Kjaer}

Débora Cristina Marinho Guimarães

Edson Juan Ferreira Nascimento

Antônio Sousa Martins Filho

Rui Machado Junior

Resumo: 0 presente trabalho acadêmico discorre a respeito de uma revisão literária com o que ocorre na saúde no sistema prisional de Roraima. Essa temática traz controvérsias e grandes debates, inclusive chegando ao Supremo Tribunal Federal. 0 objetivo desse artigo é descrever as precariedades no que tange a saúde e a dignidade da pessoa humana. Onde os tratados internacionais, dos quais o Brasil é signatário garantem que esses indivíduos do sistema prisional tenham assistência à saúde e criou mecanismos para proteger a integridade física destes, dando-lhes tratamento digno e não permitindo praticas análogas a tortura. Assim, para que mude o quadro atual desse sistema é necessário que haja um compromisso do Estado em criar políticas públicas de reeducação nas prisões.

Palavras-chave: Sistema Prisional. Assistencia à Saúde. Tortura. Serviços Ambulatoriais. Direitos dos Presos. 


\section{INTRODUÇÃO}

Atualmente a população carcerária brasileira é composta por aproximadamente 500 mil indivíduos. Os indicadores referentes a este grupo apontam que a maioria é de cor parda, jovem e com ensino fundamental incompleto. (Modernização do Sistema Penitenciário Nacional, 2011). Como este grupo é composto por uma parcela representativa da população brasileira o interessante é destacar que caso os estabelecimentos prisionais possuíssem condições mínimas para receber esses indivíduos, e nestas condições, inclui-se bem-estar e programa de atendimento à saúde, talvez houvesse que se falar em ressocialização. Além disso, o artigo 196 da Constituição Federal da República de 1988 (Constituição, 2018), na Seção II o legislador descreve claramente que a saúde é um direito fundamental de todos e dever do Estado, visando a redução dos riscos de doenças e de outros agravos sociais mediante políticas públicas e econômicas, bem como acesso universitário e igualitário, para isso, esse dispositivo constitucional reforçou a importância e supremacia do atendimento ao sujeito em situação de liberdade privada. Nesse sentido, no que tange à temática, atualmente existem diversas politicas publicas desenvolvidas pelo Sistema Único de Saúde (SUS) para resguardar que esse direito seja garantido. Para promover a isonomia integral dos que se acha encarcerados nas unidades prisionais, não só de Roraima, o Ministério da Saúde e da Justiça instituíram a Portaria Interministerial nº1.777/2003 (PORTARIA INTERMINISTERIAL № 1777, DE 09 DE SETEMBRO DE 2003, 2018), que aprovou o Plano Nacional de Saúde no Sistema Prisional. Dentre algumas dessas ações pode-se encontrar presentes o controle à tuberculose e a saúde mental, programa de imunização, diagnóstico, aconselhamento, tratamento em DST/HIV/Aids. Assim, esse trabalho busca-se apresentar as ações e serviços que deveriam, mas que não são desenvolvidos no sistema prisional de Roraima, e que de acordo com os agravos mais comuns aos indivíduos privados de liberdade, para promover à saúde desta população, visto que, recentemente o estado passou por um surto de tuberculose dentro da Penitenciária Agrícola do Monte Cristo de Roraima.

\section{PERCURSO METODOLÓGICO}

Para a elaboração desse trabalho de revisão bibliográfica, foram selecionadas legislações, teses e publicações relacionadas à "dignidade da pessoa humana no sistema prisional". A situação à frente denota de inúmeras formas como têm sido violados os direitos humanos fundamentais dentro de um sistema que tem por dever assegurar o bem-estar do preso para promover a ressocialização. Um perfeito exemplo disso são os muitos relatos de negligencia e de maus tratos. E as incontáveis fugas da Penitenciária Agrícola do Monte Cristo de Roraima.

\section{FUNDAMENTAÇÃO TEÓRICA}

O objetivo desse artigo é versar sobre ações e serviços de saúde que deveriam ser prestados nesta unidade prisional, considerando as problemáticas existentes na penitenciária agrícola, além de descrever as precariedades no que tange a saúde e a dignidade da pessoa humana, princípios constitucionais garantidos ao indivíduo em situação de reclusão. Onde os tratados internacionais, dos quais o Brasil é signatário garantem que esses indivíduos do sistema prisional tenham assistência à saúde e criou mecanismos para proteger a integridade física destes, dando-lhes tratamento digno e não permitindo praticas análogas a tortura. Assim, esse trabalho tem por objetivo esclarecer a situação vivida por presos, face aos inúmeros direitos que tem sido violados. Diante disso, relatórios, feitos pela Ordem dos Advogados do Brasil, mostraram em 2017 (RELATÓRIO № 01/2016 DE VISITA/ INSPEÇÃO A PENITENCIÁRIA AGRÍCOLA DO MONTE CRISTO, 2017) a real situação vivida pelos detentos. Além disso, o mais consternador é a situação crítica em que se encontram os doentes, uma crise de tuberculose desenvolveu-se recentemente na penitenciária referida, (SOUSA, 2018). Os fatos abordados nesse trabalho foram extraídos do relatório do Conselho Nacional de Política Criminal e Penitenciária e da Ouvidoria do Departamento Penitenciário Nacional, órgão vinculado ao Ministério da Justiça, Penitenciaria Agrícola do Monte Cristo, (RELATÓRIO DE INSPEÇÃO EM ESTABELECIMENTOS PENAIS NO ESTADO DE RORAIMA, 2014).

Os órgãos supramencionados realizaram vistoria em quatro presídios, no estado de Roraima, nos dias 05 e 06 de junho de 2014. 0 primeiro presídio visitado foi a cadeia pública de Roraima, localizada em Boa Vista. Nesse presidio, à época encontravam-se 175 reeducandos, sendo todos do sexo masculino, (RELATÓRIO DE INSPEÇÃO EM ESTABELECIMENTOS PENAIS NO ESTADO DE RORAIMA, 2014). E no que tange a área de assistência à saúde, não existia Unidade Básica de Saúde do SUS, não obstante o fato de que as questões sexuais e doenças sexualmente transmissíveis, não possuíam sequer a distribuição de preservativos. Os 
internos não tinham acesso a medicamentos da linha comercial oferecidos pelo presidio. Com a falta de medicamentos, era permitido que os familiares providenciassem os remédios e aparatos necessários à manutenção da saúde do preso. 0 que não difere da situação atual.

No referido presidio os presos tinham acesso a médico particular providenciado pelos seus familiares, o serviço de vacinação deve ser feito com regularidade, (RELATÓRIO DE MISSÃO A UNIDADES DE PRIVAÇÃO DE LIBERDADE NO ESTADO DE RORAIMA, 2018), os exames médicos são efetuados quando necessários, e, não existia a presença de uma ambulância na unidade prisional citada. Os detentos recebiam atendimento de saúde fora da unidade prisional, no Hospital Geral de Roraima (HGR).

A presença de insetos e roedores pode ser uma problemática perigosa, uma vez que a pesar de ser necessário um trabalho mais específico para combater essas infestações, se constatado a presença de ratos mortos e uma grande quantidade de lixo na área externa, põe-se em risco a vida de todos ali presentes. E no que tange a assistência médica e psicológica, embora não sejam fixas, são atendidas quando solicitado por autoridades competentes, (RELATÓRIO DE MISSÃO A UNIDADES DE PRIVAÇÃO DE LIBERDADE NO ESTADO DE RORAIMA, 2018).

\section{PENITENCIÁRIA FEMININA DO MONTE CRISTO}

Essa unidade prisional abrigava setenta e cinco mulheres, onde não existia unidade básica de saúde do Sistema Único de Saúde (SUS), no entanto as detentas tem acesso ás medicações pré-definidas pelo SUS para farmácias de unidades prisionais e também medicações prescritas que não estejam no pacote do SUS, (RELATÓRIO DE MISSÃO A UNIDADES DE PRIVAÇÃO DE LIBERDADE NO ESTADO DE RORAIMA, 2018). Para as detentas gestantes é feito o exame de pré-natal como também é feita com regularidade vacinação em época de campanhas. As reeducandas tem acesso aos exames necessários. E caso necessitem de atendimento de emergência, que seja prestado com médico particular, é permitido a contração desse profissional pelos seus familiares.

A distribuição de preservativo para as detentas é rotineira, quando há necessidade de atendimento médico são atendidas pela Unidade Básica de Saúde, a unidade prisional dispõe de uma ambulância que faz a locomoção das presas para o local de atendimento, (SOUSA, 2018).

Entretanto, inexiste um trabalho que vise a prevenção ou controle de doenças infectocontagiosas, essa falha contribui para o surgimento de epidemias, infecções e surto de doenças no local.

No que tange ao Programa de necessidades do módulo de saúde por tipo de estabelecimento penal, denota-se uma falha inescusável no cumprimento das recomendações, uma vez que não existe Consultório ginecológico, cela enfermaria com solário e sala de coleta de material para laboratório, percebe-se que as recomendações do programa não são seguidas, de forma a violar bruscamente inúmeros direitos do preso à saúde, bem-estar e privacidade, bem como a dignidade da pessoa humana.

Mesmo que a assistência à saúde não funcione a contento, as presas parecem satisfeitas pelo fato de apenas receber o atendimento ginecológico e obstétrico, no entanto coexistem reiteradas reclamações a respeito da falta de procedimentos e medicamentos específicos, (RELATÓRIO DE MISSÃO A UNIDADES DE PRIVAÇÃO DE LIBERDADE NO ESTADO DE RORAIMA, 2018).

\section{PENITENCIÁRIA AGRÍCOLA DO MONTE CRISTO}

A Penitenciária Agrícola Monte Cristo tem capacidade máxima para comportar, de acordo com as recomendações, 750 presos no total, no entanto são 1133 presos registrados, (RELATÓRIO DE MISSÃO A UNIDADES DE PRIVAÇÃO DE LIBERDADE NO ESTADO DE RORAIMA, 2018).

A assistência de saúde a qual passamos a descrever existe na Unidade Prisional, porem apenas uma unidade básica de saúde do SUS presta assistência, há a distribuição de preservativos aos detentos, e, embora seja precário os presos tem acesso às medicações defendidas pelo SUS para unidades prisionais. É permitido o acesso a medicação prescrita que não esteja no pacote do SUS, desde que seja providenciado por familiares.

As vacinações de campanha são efetuadas com regularidade nos presos, e lhes é permitido o acesso ao atendimento particular, desde que os familiares contratem um profissional da área, (SOUSA, 2018). Os exames médicos são feitos quando necessários. E não são realizados trabalhos que visem a prevenção ou o controle de doenças infectocontagiosas, ainda assim, mesmo abrigando um quantitativo de quase o dobro 
acima da capacidade permitida para o atendimento da penitenciária, não existe ambulância na unidade prisional.

A Penitenciária Agrícola do Monte Cristo chega ao extremo de não atender quase nenhum pré-requisito do Programa de necessidades do módulo de saúde por tipo de estabelecimento penal, (RELATÓRIO DE MISSÃO A UNIDADES DE PRIVAÇÃO DE LIBERDADE NO ESTADO DE RORAIMA, 2018). Dentre todas as instalações pode-se constatar a ausência de sala de procedimento, de sala de coleta de material para laboratório e de locais adequados para atendimentos médicos e odontológicos.

Por parte dos detentos, no que diz respeito a assistência de saúde, há várias reclamações, alguns presos possuem diabetes, outros tantos estão com tuberculose, e sem tratamento, a falta de ambulância, de fornecimento de medicamento suficiente para atender a demanda, falta de médico e enfermeiro, faz com que um determinado preso tenha de prestar atendimento de enfermaria à toda população carcerária, (SOUSA, 2018).

\section{PRESTAÇÃO DE ASSISTÊNCIA À SAÚDE}

Tratar de saúde na Penitenciária Agrícola do Monte Cristo, envolve tanto a saúde das pessoas privadas de liberdade quanto daqueles que estão lá para resguardar a segurança dos próprios detentos. Nesse processo deverão estar envolvidos não somente a população carcerária, mas também todos que lá se encontram. E, de acordo com o que o legislador descreveu na constituição federal, " a saúde é um direito de todos e um dever do estado", (Constituição, 2018). Ao expressamente colocar como dever do Estado o legislador promoveu a assistência material em relação à higiene, instalações e o acesso ao atendimento médico, farmacêutico, e o odontológico.

\section{PLANO NACIONAL DE SAÚDE NO SISTEMA PENITENCIÁRIO}

O plano nacional de saúde no sistema penitenciário, (PLANO NACIONAL DE SAÚDE NO SISTEMA PENITENCIÁRIO, 2018) visa contemplar todos os indivíduos recolhidos em qualquer penitenciária, presídio, colônias agrícolas ou agroindustriais, hospitais de custódias e tratamento psiquiátrico. Não incluindo apenas aqueles que se encontram presos em penitenciarias federais, mas também os de regime aberto, e os presos provisórios em cadeias públicas e distritos policiais.

Ocorre que, antes ainda havia equipes de saúde no sistema prisional, que prestavam consultas medicas duas vezes na semana para os presos, tanto na feminina como no masculino, esses dados são do período de 2009, (PLANO NACIONAL DE SAÚDE NO SISTEMA PENITENCIÁRIO, 2018) o que não permaneceu muito tempo devido a mudanças feitas por autoridades competentes.

Atualmente a realidade da Penitenciária Agrícola do Monte Cristo de Roraima é mais grave e preocupante, relatos de familiares, colhidos em 2017, (SOUSA, 2018) apontam que eles vêm buscando atendimento para os detentos em razão de diagnósticos de tuberculose, visto que, estes estão sento mantidos isolados dos demais presos no intuito de evitar um surto da doença. Acontece que, com as precárias condições em que se encontra o sistema penitenciário roraimense da referida penitenciária, entre elas, superlotação, condições sanitárias rudimentares, alimentação insuficiente, ausência de assistência médica, jurídica, educacional, profissional e psicológica, (RELATÓRIO DE MISSÃO A UNIDADES DE PRIVAÇÃO DE LIBERDADE NO ESTADO DE RORAIMA, 2018), não há que se falar em ressocialização, no entanto há que se questionar os motivos para não se falar no Estado Inconstitucional das Coisas que vem ocorrendo nesse presídio, na área da saúde.

Uma das áreas mais comprometidas na saúde do indivíduo privado de liberdade tem sido a sua saúde mental, como um indivíduo que tem seus direitos fundamentais violados sucessivamente poderia manter sua saúde mental, e quanto tempo isso seria possível, e se possível, como recolocar esse indivíduo na sociedade sem que ele venha a se tornar um reincidente, todos esses questionamentos são pertinentes nessa temática. Se o indivíduo já como vítima de um meio social corrompido, chega à unidade prisional com um certo comprometimento mental, a probabilidade de desenvolvimento de algum distúrbio psíquico é patente devido as restrições encomendadas nas unidades prisionais.

Os problemas de saúde, nessa unidade prisional, agravam-se com a constante violência que ocorre entre os presos por causa das facções, e conflitos com o Estado, representado por policiais e agentes do sistema penitenciário. Somando-se ao uso de drogas e ao sedentarismo, faz do presídio um local de grande risco para saúde física e mental de todos que estão constantemente lá dentro. Além disso, diante das sugestões 
de ampliação das normas da Agencia Nacional de Vigilância Sanitária, (Estabelece procedimentos para orientar e instrumentalizar as ações e serviços de saúde do trabalhador no Sistema Único de Saúde (SUS)., 2018) para toda equipe de saúde atua, além dos problemas federativos e entre poderes, já que, a rigor, laudos de insalubridade deveriam gerar o fechamento das unidades prisionais inadequadas a superlotação e a insalubridade, que se refletem nas dificuldades encontradas para higienização, repousar, dormir, tudo isso reunido torna problemática a formulação de uma política que aumente o acesso às ações e serviços de saúde, fato esse exacerbado pelo contexto de privação de direitos no contexto histórico de vida das pessoas privadas de liberdade.

As ações mínimas como, controle da tuberculose, controle da hipertensão, e diabetes, hanseníase, DST/HIV/Aids, hepatites, saúde bucal, saúde da mulher, saúde mental, programa de imunizações, exames laboratoriais, aquisição e controle de medicamentos, não são executadas.

Quanto a não prestação desses serviços, pode-se comparar esses tratamentos a uma pena de caráter cruel e práticas de tortura, que são expressamente vedadas pela Constituição Federal da República de 1988, em seu artigo 5, inciso III, (Constituição, 2018), não obstante outros direitos fundamentais, os presos da penitenciária do Monte Cristo estão expostos constantemente a riscos que podem ofender a integridade física e mental deles, a falta de infraestrutura acentua a proliferação de doenças infectocontagiosas e denota uma desvalorização do preso. Ignorando suas queixas apresentadas inicialmente aos agentes penitenciários. Estes por sua vez, fazem uma avaliação informal do caso e decidem, com base em critérios pessoais, o encaminhamento ou não do preso ao serviço médico, resultando em um controle informal do acesso à prestação dos serviços de saúde.

A produção de ações de saúde hierarquizadas e focadas por parte dos agentes penitenciários, da administração penitenciaria e da sociedade civil em considerar a saúde como direito do preso.

Assim, tendo a firme conviç̧ão de que a reclusão contém em si teoricamente a proposta de promover a recuperação do recluso, facilitando sua inclusão social e ressocialização. A função social do presidio era devolver a sociedade homens honrados e cidadãos trabalhadores, embora essa ideia pareça ilógica, é evidente, nos dias atuais, em muitos setores sociais, que encontra se bastante enraizado o conceito de que a prisão é um lugar onde se deve propiciar o maior sofrimento possível e a mortificação do delinquente.

Não obstante, o Estado observar o princípio da legalidade somente durante a fase de apuração do fato criminoso, com respeito ao contraditório à ampla defesa, sendo necessário que após a condenação, na fase da execução penal, o autor da infração penal tenha seus direitos ainda respeitados. A mutação do ser humano em "monstro" inicia desde o preparatório do curso de formação de agentes, onde os mesmos são treinados não como policiais, mas como combatentes de guerra, qualquer pessoa que passe pelos sofrimentos submetidos nesses treinamentos, será capaz sem titubear de submeter preso ou qualquer pessoa sob sua tutela a esses mesmos tratamentos degradantes e torturadores, (NOGUEIRA, 2013).

A falência do sistema prisional é patente e custa a sociedade o preço da falência de tudo que os direitos humanos veem construindo e conquistado historicamente. Causando em um efeito dominó uma falha na educação, na família, na igreja, na saúde, na segurança pública, tudo isso é o resultado de uma ideia preconceituosa que criou-se e se incorporou na vida daquele detento, daquela pessoa humana que nasceu em condições deploráveis e que o sistema carcerário é tão somente a continuação de tudo que lhe foi causado. 0 sistema prisional roraimense padece claramente de um Estado Inconstitucional das Coisas e o Estado é completamente omisso quanto a isso.

\section{ANÁLISE E RESULTADOS}

A Corte Constitucional Colombiana, foi que desenvolveu pioneiramente essa teoria em meados de 1997, o Estado Inconstitucional de Coisas acontece quando vários direitos (Modernização do Sistema Penitenciário Nacional, 2011), esse quadro de violações tem sido agravado devido a omissão criminosa e dolosa dessas mesmas autoridades, de forma que a situação atual carcerária pode ser considerada irreversível para o estado de Roraima. A tendência é apenas a calamidade desse sistema até um eminente colapso. A responsabilidade seria então da falta de estrutura e de interesse do Estado, visto que o reconhecimento do Estado Inconstitucional das Coisas implica em uma complexidade além do entendimento nacional, mas em remédios a serem emitidos a diversos órgãos em uma escala de pluralidade extensa, e colocaria o estado de Roraima em mais um quadro de litigio estrutural com a União. Tomando como justificativa o pretexto de que os órgãos recebedores dos remédios não têm capacidade ou interesse em agir e não foram capazes de sozinhos reestabelecerem a ordem e a conformidade das coisas. 
Reconhecer que o sistema prisional de Roraima passa por esse estado faria com que a Corte assumisse a situação e promovesse então a proteção objetiva no que tange aos direitos fundamentais sacramentados na Constituição Federal de 1988.

O sistema prisional brasileiro em si já é alvo de críticas e citado em julgados, (http://ufrr.br/direito/index.php?option=com_phocadownload\&view=category\&download=193:0estado-de-coisas-inconstitucional-na-busca-da-efetivacao-da-dignidade-da-pessoa-humana-no-sistemaprisional-do-estado-de-roraima-autora-lianne-dantas-de-melo-orientador, 2018), como um verdadeiro exemplo de Estado Inconstitucional das Coisas, partindo dos pressupostos que Carlos Alexandre Azevedo Campos cita na ADPF 347, (Campos, 2018) existem exigências para que se reconheça esse estado, entre elas, a violação generalizada, sucessiva e massiva dos direitos fundamentais de um número significativo de pessoas e a prolongada omissão ou inércia das autoridades competentes no que diz respeito ao cumprimento de suas obrigações ante a promoção e garantia desses direitos. A Corte então assumiria um papel atípico às suas funções naturais, mas que compete exclusivamente a ela.

O Estado Inconstitucional de Coisas é um fenômeno novo, que traz uma natureza jurídica diferente de tudo que já se viu em matéria de constitucional, com mais 20 anos dessa descoberta revolucionária no meio jurídico, é importante ressaltar que, atualmente alguns países já aderiram, inclusive do continente americano.

Após a outorga da Sentencia de Unificación (SU) 559/1997 pela Corte Constitucional Colombiana, foi a primeira vez em que o Estado Inconstitucional de Coisas ficou conhecido pelo mundo, a Corte enviou cópias fiéis da Sentença de Unificación para inúmeros órgãos vinculados a Poderes Políticos que estavam envolvidos na referida vulneração generalizada de diversos direitos humanos. Então, após isso, esse caso fez com que a Corte Constitucional Colombiana analisasse e julgasse a questão da problemática vivida no Sistema Prisional, que encontrava se em um verdadeiro caos e violentava os direitos humanos daquela população, nessa Sentencia de Tutela, 153/98, foi reconhecido o então Estado Inconstitucional de Coisas. E no que tange o problema com a crise migratória e o deslocamento massivo e forçado de pessoas, as migrações ocorridas por motivos de ameaças, perigo de vida destes indivíduos transladados pelo próprio Estado, por questões políticas, os criminosos das facções e outros diversos conflitos, no qual a Sentencia de Tutela 025/2004 reconheceu também o Estado Inconstitucional de Coisas nessa espécie de migração.

\section{CONSIDERACÕES}

O Estado Inconstitucional de coisas é então mais que um novo instituto, é um novo conceito, que já foi reconhecido em vários casos analisados pela Corte Constitucional, e no Brasil é uma tese inovadora, que foi abordada recentemente pelo jurista Alexandre Daniel Sarmento na petição da ADPF no 347/DF (Campos, 2018) contra a União, questiona-se aqui os motivos de o Sistema Penitenciário de Roraima, que preenche os requisitos essenciais para tal caracterização do instituto tratado nesse trabalho, não ser reconhecido no Estado. Assim este, ou seja, o Estado Inconstitucional de Coisas acontece diariamente nesse sistema.

O Estado Inconstitucional de Coisas por ser uma espécie nova e estruturada de Ativismo, no qual merece guarida no nosso ordenamento jurídico, cujo tem o condão de combater as irregularidades do governo e representação política parlamentar, em relação a Direitos Fundamentais massivamente violados pela falta de políticas públicas, reiteradas omissões dos órgãos e Poder competente para elaboração destas políticas, bem como sua execução no afã de garantir tais direitos, como também irá diminuir o número de demandas individuais.

Em suma para que se possa ver um sistema penitenciário mais organizado e digno, a solução seria reconhecer o Estado Inconstitucional de Coisas dentro da Penitenciária Agrícola do Monte Cristo, onde o Supremo Tribunal Federal (STF) irá além de exigir, fiscalizar, promover, incentivar e orientar os Poderes Executivo e Legislativo de forma a dirimir as falhas existentes atualmente nesse sistema, mas para tanto é necessário entender e aceitar que o Sistema Prisional Roraimense, por inteiro, precisa de uma urgente intervenção judiciária. Entende-se que o Supremo Tribunal Federal, não é a Corte Constitucional do Brasil, e que esse Tribunal possui status de cumprir várias funções como Corte Suprema, bem como Corte Constitucional, por tanto, o mesmo seria competente no Brasil para julgar e reconhecer o Estado Inconstitucional das Coisas na Monte Cristo, visto que possui funções híbridas e peculiaridades subjetivas especiais. Logo, são necessárias ações, bem mais que simples esforços, para salvar esse sistema. A Penitenciária Agrícola do Monte Cristo hoje, é bem mais que um local prisional, é uma universidade do crime. 


\section{REFERÊNCIAS}

[01] Campos, C. A. $(24$ de 09 de 2018). Consultor Jurídico. Fonte: Consultor Juridico: https://www.conjur.com.br/2015-set-01/carlos-campos-estado-coisas-inconstitucional-litigio-estrutural

[02] Constituição. (24 de 09 de 2018). Fonte: Site do Planalto: http://www.planalto.gov.br/ccivil_03/Constituicao/Constituicao.htm

[03] Estabelece procedimentos para orientar e instrumentalizar as ações e serviços de saúde do trabalhador no Sistema Único de Saúde (SUS). (24 de 09 de 2018). Fonte: Estabelece procedimentos para orientar e instrumentalizar as ações e serviços de saúde do trabalhador no Sistema Único de Saúde (SUS).: http://www.anvisa.gov.br/anvisalegis/portarias/3908_98.htm

[04] http://ufrr.br/direito/index.php?option=com_phocadownload\&view=category\&download=193:o-estadode-coisas-inconstitucional-na-busca-da-efetivacao-da-dignidade-da-pessoa-humana-no-sistema-prisional-do-estadode-roraima-autora-lianne-dantas-de-melo-orientador. $(24$ de 09 de 2018). Fonte: http://ufrr.br/direito/index.php?option=com_phocadownload\&view=category\&download=193:o-estado-de-coisasinconstitucional-na-busca-da-efetivacao-da-dignidade-da-pessoa-humana-no-sistema-prisional-do-estado-deroraima-autora-lianne-dantas-de-melo-orientador:

http://ufrr.br/direito/index.php?option=com_phocadownload\&view=category\&download=193:o-estado-de-coisasinconstitucional-na-busca-da-efetivacao-da-dignidade-da-pessoa-humana-no-sistema-prisional-do-estado-deroraima-autora-lianne-dantas-de-melo-orientador

[05] (2011). Modernização do Sistema Penitenciário Nacional. Braspilia: Ministério da Justiça.

[06] NOGUEIRA, R. (2013). COMO NASCEM OS MONSTROS: A HISTORIA DE UM EX-SOLDADO DA POLICIA MILITAR DO ESTADO DO RIO DE JANEIRO. RIO DE JANEIRO: TOPBOOKS.

[07] PLANO NACIONAL DE SAÚDE NO SISTEMA PENITENCIÁRIO. (24 de 09 de 2018). Fonte: PLANO NACIONAL DE SAÚDE NO SISTEMA PENITENCIÁRIO: http://bvsms.saude.gov.br/bvs/publicacoes/cartilha_pnssp.pdf

[08] PORTARIA INTERMINISTERIAL № 1777, DE 09 DE SETEMBRO DE 2003. (24 de 09 de 2018). Fonte:

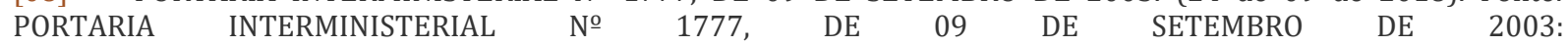
http://www.crpsp.org.br/sistemaprisional/leis/2003Portaria1777.pdf

[09] (2014). RELATÓRIO DE INSPEÇÃO EM ESTABELECIMENTOS PENAIS NO ESTADO DE RORAIMA. BOA VISTA: MINISTÉRIO DA JUSTIÇA.

[10] RELATÓRIO DE MISSÃO A UNIDADES DE PRIVAÇÃO DE LIBERDADE NO ESTADO DE RORAIMA. (24 de 09 de 2018). Fonte: RELATÓRIO DE MISSÃO A UNIDADES DE PRIVAÇ̃̃O DE LIBERDADE NO ESTADO DE RORAIMA: https://clinicasdotestemunhosc.weebly.com/uploads/6/0/0/8/60089183/aula_5-relat\%C3\%B3rio_mnpctroraima.pdf

[11] (2017). RELATÓRIO № 01/2016 DE VISITA/ INSPEÇÃO A PENITENCIÁRIA AGRÍCOLA DO MONTE CRISTO. BOA VISTA: ORDEM DOS ADVOGADOS DO BRASIL - RORAIMA.

[12] SOUSA, H. S. (23 de AGOSTO de 2018). ENTREVISTA PESSOAL. (N. AZEVEDO, Entrevistador) 


\title{
Capítulo 4
}

A educação em direitos humanos no Mercosul: Debates necessários na sociedade contemporânea

\author{
Rosane Beatris Mariano da Rocha Barcellos Terra \\ Maria Paula da Rosa Ferreira \\ Guilherme Streit Carraro \\ Rodrigo Cristiano Diehl
}

Resumo: 0 presente estudo aborda a educação em direitos humanos na sociedade contemporânea como mecanismo eficaz na promoção e disseminação dos direitos humanos no âmbito do Mercosul. São elencados e debatidos os principais aspectos que circundam os desafios a serem enfrentados no plano internacional para a efetivação desses direitos. Neste contexto surge a educação em direitos humanos como uma proposta que, além de emancipadora, capaz de fomentar uma cultura de paz, comprometida com a formação de cidadãos livres, críticos, responsáveis e comprometidos com a sociedade na qual vivem e da qual fazem parte, sem deixar de lado a história da humanidade. Para tanto, utilizou-se o método hipotético dedutivo, baseado em levantamento bibliográfico.

Palavras-chave: Desafios; direito humanos; educação; Mercosul; Perspectivas. 


\section{INTRODUÇÃO}

Aduz-se que caracterizada como uma das mais brilhantes evoluções da sociedade contemporânea está a disseminação e concretização dos direitos humanos. Neste cenário, o presente artigo tem por escopo central analisar a educação em direitos humanos âmbito do Mercosul como mecanismo capaz de promover a sua proteção na conjectura hodierna, isto é, na era da globalização. Para isso, parte-se do pressuposto que esses direitos/valores a serem resguardados florescem na medida das necessidades humanas, pois se referem a um processo constante de construção que, inclusive, comporta reconstruções.

Assim, em um primeiro momento, debruça-se sobre os desafios que os direitos humanos deverão enfrentar no plano internacional, entre eles, o universalismo versus o relativismo cultural; a laicidade estatal frente os fundamentalismos religiosos e a diversidade frente à difusão de um discurso intolerante. Frente a esses desafios da internacionalização dos direitos humanos, o segundo tópico traz à tona a educação em direitos humanos como uma proposta que, além de emancipadora, constitui-se em uma missão que permite a todos, sem exceção, frutificar seus talentos e suas potencialidades, o que implica, por parte de cada um, a capacidade de assumir sua própria responsabilidade e de realizar seu projeto pessoal.

Neste contexto, o deve ser entendido como um ser que, ao mesmo tempo, é natural e cultural, isto é, deve ser "educado" pela sociedade. A educação em direitos humanos constituiu uma das dimensões fundamentais para a plena efetivação dos direitos humanos, seja ela através da educação formal ou da educação popular.

Para isto, utiliza-se o método hipotético dedutivo como metodologia de abordagem, uma vez que consiste na adoção tanto do procedimento racional quanto do procedimento experimental. Dessa forma, a pesquisa desenvolver-se-á sobre preposições hipotéticas que se acredita serem viáveis. No que concerne às técnicas, o aprofundamento do estudo será realizado com base em pesquisa bibliográfica, baseada em dados secundários, como, por exemplo, livro, artigos científicos, publicações avulsas, revistas e periódicos qualificados dentro da temática proposta.

\section{OS DESAFIOS DOS DIREITOS HUMANOS NO PLANO INTERNACIONAL}

Na atualidade, uma das questões mais importantes centra-se na aplicação tanto no âmbito nacional quanto internacional dos direitos humanos. Contudo, para que se chegasse a este patamar de discussões, foram travadas, ao longo da história, diversas lutas, entre elas, aquelas perpetradas por trabalhadores urbanos, camponeses, mulheres, indígenas e muitos outros segmentos minoritários da sociedade, que se posicionaram contra uma elite que resistia em manter os seus privilégios (DHESCA, 2008).

Os direitos humanos nascem na medida das necessidades humanas. Não nascem de uma hora para a outra, pois se trata de um processo de construção que comporta reconstruções, refletindo uma filosofia dos valores, particularmente dos valores morais, simbolizado pela luta e ação social. Portanto, podem ser compreendidos como uma construção consciente dirigida a garantir a dignidade humana e a evitar sofrimentos, em face da persistente brutalidade humana (PIOVESAN, 2010).

Nesta perspectiva de surgimento dos direitos humanos, destaca-se o da pessoa humana, segundo relatório da Plataforma Dhesca (2008) percebe-se uma certa resposta as atrocidades cometidas durante a Segunda Guerra Mundial. A violência absurda empregada naquele período alertou para a necessidade da criação de padrões, no âmbito internacional, de tolerância às mais diversas culturas, étnicas e grupos sociais. Neste sentido, a Organização das Nações Unidas (ONU) aprovou, em 1948, a Declaração Universal dos Direitos Humanos, prevendo um mundo mais igualitário, onde todos os seres humanos gozariam de liberdade de expressão, de crença e de viverem a salvo de toda forma de temor.

Assim, o último momento marcante no percurso história da noção de dignidade da pessoa humana pode ser classificado como o mais chocante. A revelação dos horrores cometidos durante a Guerra transtornou completamente as convicções que até ali eram entendidas como pacíficas e universais. "A terrível facilidade com que milhares de pessoas - não apenas alemãs, diga-se, mas de diversas nacionalidades europeias - abraçaram a ideia de que o extermínio puro e simples de seres humanos podia consistir em uma política de governo válida, ainda choca" (BARCELOS, 2002, p. 108).

Essa visão é resultado da internacionalização dos direitos humanos como réplica às barbaridades cometidas durante o nazismo, ou seja, um efeito à Pós-Guerra. Tendo o Estado como grande violador dos direitos humanos, a missão do nazismo foi restringir a titularidade desses direitos apenas para determinada raça, a ariana puríssima. Neste momento histórico é que se inicia a concretização da reconstrução dos direitos humanos, pois em quadro deprimente de violação de tais direitos, excluindo o 
valor da pessoa como valor-fonte do Direito, certamente, após, faz-se necessária a reconstrução destes (PIOVESAN, 2010).

Contudo, esta mesma Declaração encontrava-se em um plano além, ou seja, seus artigos não estavam sendo aplicados na vida real das pessoas. Em vista disso, surge certa retração ao positivismo do ordenamento jurídico, o de caráter meramente formal. Ressurgem ideias de Kant, no sentido de dignidade, tratando o ser humano como "pessoa", com um fim em si mesmo, e não como "coisa", descartáveis. Desta forma, chegou-se a conclusão de que estes direitos deveriam ser definidos em maior detalhe na forma de um tratado internacional, onde todos os países participantes da ONU ratificassem e cumprissem o referido tratado. Porém, tudo isso estava ocorrendo em meio a Guerra Fria, onde havia uma inegável disputa política de fundo na questão dos direitos humanos.

Esta disputa política dividiu o planeta em dois grandes blocos: o primeiro com um teor puramente capitalista, liderado pelos Estados Unidos da América, onde se tinha, como prioritários, os direitos civis e políticos, como a liberdade de expressão. E no outro lado do mundo, encontrava-se o segundo bloco, comandado pela antiga União Soviética, puramente socialista, e tendo como viés prioritário a igualdade social e econômica, como a alimentação, o trabalho, a moradia, entre outros (DHESCA, 2008).

A partir desse grande embate, o texto acabou sendo dividido em dois tratados de direitos humanos para que fossem aprovados mais facilmente pela Assembleia Geral da ONU. Um deles denominar-se-ia Pacto Internacional de Direitos Civis e Políticos (PIDCP) e o outro de Direitos Econômicos, Sociais e Culturais (PIDESC), ambos com vigência nos dias atuais.

Como visto anterior, a reação da comunidade internacional à barbárie do fascismo e do nazismo, em geral, consagrou a dignidade da pessoa humana no âmbito internacional como principio máximo dos ordenamentos jurídicos. Nesta linha, Barcelos (2002, p. 109, grifo nosso) disciplina sobre a inclusão em algumas Cartas Políticas da "dignidade da pessoa humana como fundamento do Estado que se criava ou recriava (Alemanha, Portugal e Espanha, (...); a Bélgica tratou do tema através de emenda à Constituição), juridicizando, com estatura constitucional, o tema".

A partir da admissão desses "novos direitos" nos ordenamentos jurídicos mundiais, iniciou-se também a discussão no âmbito acadêmico, pois não se encaixavam em nenhuma dimensão de direitos. Por isso, criase uma nova categoria baseado no caráter universal, e levando em consideração as suas peculiaridades como a aplicação genérica a todas as pessoas e a sua forte ligação com o terceiro princípio encontrado na Revolução Francesa, a fraternidade.

Ainda, a Conferência Mundial de Viena (1993) reafirmou o compromisso mundial pelos direitos humanos e declarou-os como indivisíveis e interdependentes. As características que definem tais direitos possuem outras prerrogativas como universais (valem para todos); interdependentes (um depende do outro para ser concretizado plenamente), indivisíveis (os direitos humanos passam a ser considerados como um todo, não podendo ser divididos) e, por último, não menos importante, eles classificam-se como inalienáveis (não podem ser trocados, compensados ou vendidos por outros direitos ou garantias) (DHESCA, 2008).

Neste contexto, a ideia de que a proteção dos direitos humanos não deve reduzir-se ao domínio reservado ao Estado, fortalece-se, pois é tema de interesse internacional. Essa concepção inovadora aponta duas consequências: a primeira é a revisão da noção tradicional de soberania absoluta do Estado, isto é, transita-se de uma concepção de soberania, centrada no Estado, para uma concepção de soberania, centrada na cidadania universal; e a segunda, trata-se da ideia de que o indivíduo deve ter direitos protegidos na esfera internacional. (PIOVESAN, 2010).

A flexibilização da soberania estatal implica em reconhecer o Estado como um tutor e não mais como o senhor de todos os seus cidadãos, estando sujeito à prestação de contas a comunidade internacional. Essa flexibilização pode ser personificada em intervenções internacionais "realizadas por comissões especialmente constituídas para verificar, a partir de denúncias de vítimas ou comunicações de outros Estados, as condições de tratamento dadas à pessoa e o respeito aos direitos humanos, podem, ao final, aplicar sanções e impor reparações" (SALDANHA, 2006, p. 97).

Neste cenário, a Declaração de 1948 vem a inovar ao introduzir a chamada concepção contemporânea de direitos humanos, marcada pela universalidade e indivisibilidade desses direitos. Universalidade porque clama pela extensão universal dos direitos humanos e indivisibilidade porque a garantia dos direitos civis e políticos é condição para a observância dos direitos sociais, econômicos e culturais, assim os direitos humanos compõem uma unidade indivisível, interdependente e inter-relacionada (PIOVESAN, 2010). 
A universalização dos direitos humanos permitiu a formação de um sistema internacional de proteção desses direitos. Esse sistema é integrado por tratados internacionais de proteção que refletem a consciência ética contemporânea compartilhada pelos Estados, na medida em que invocam o consenso internacional acerca dos temas centrais aos direitos humanos. Com este sistema normativo global, surgem os sistemas regionais de proteção, que buscam internacionalizar os direitos humanos nos planos regionais, principalmente na Europa, América e África. Consolida-se a convivência do sistema global da ONU com instrumentos do sistema regional, por sua vez integrado pelos sistemas interamericano, europeu e africano de proteção aos direitos humanos (PIOVESAN, 2010).

Os sistemas global e regional são complementares e são inspirados pelos valores e princípios da Declaração Universal, compõem o universo instrumental de proteção dos direitos humanos no plano internacional. Os diversos sistemas de proteção de direitos humanos, somando-se ao sistema nacional de proteção, proporcionam a maior efetividade possível na tutela e promoção de direitos humanos (PIOVESAN, 2010).

Desse modo, Argentina, Brasil, Paraguai e Uruguai assinaram, em 26 de março de 1991, o Tratado de Assunção, com o objetivo de criar o Mercado Comum do Sul (MERCOSUL). A finalidade primordial do Tratado de Assunção é a integração dos Estados Partes por meio da livre circulação de bens, serviços e fatores produtivos, do estabelecimento de uma Tarifa Externa Comum (TEC), da adoção de uma política comercial comum, da coordenação de políticas macroeconômicas e setoriais, e da harmonização de legislações nas áreas pertinentes (MERCOSUL, online).

Sendo assim, nas palavras de Del'Olmo (2001, p. 77) o Mercado Comum do Sul (Mercosul) constituiu um bloco econômico regional formando pelos quatro países que se situam na parte meridional do continente americano. São eles o Brasil, Argentina, Paraguai e Uruguai9. "A par de ser uma aspiração acalentada desde o começo do século XIX, por idealistas e pacificadores da estirpe de Simão Bolivar e José de San Martin, sua configuração passou a ser concreta apenas no século XX".

Dessa forma, importante o pensamento de Wolkmer (1998, p. 48) quando afirma ser desafiador projetar um direito comunitário às comunidades latino-americanas, "não só marcada pelo forte legalismo de cunho nacional-monista, mas, sobretudo, pela histórica tradição do Estado como fonte privilegiada de produção legislativa. 0 modelo de direito identificado com a lei e como elaboração exclusiva do Estado vem dominando oficialmente os países periféricos da América do Sul”.

Entretanto, a efetivação dos direitos humanos na ordem internacional e regional do Mercosul, enfrenta inúmeros desafios, entre eles, o embate entre o universalismo e o relativismo cultural; a laicidade do Estado frente aos fundamentalismos religiosos e o respeito à diversidade versus a propagação de um discurso intolerante.

O primeiro desafio - universalismo versus relativismo cultural - retoma o dilema a respeito dos fundamentos dos direitos humanos: por que se tem direitos? Cada cultura possui seu próprio discurso acerca dos direitos fundamentais, que normas de direitos humanos podem ter um sentido universal ou são culturalmente relativas, uma que decorrem da dignidade humana, na condição de valor intrínseco à condição humana. A abertura de diálogo entre as culturas, com respeito à diversidade e com base no reconhecimento do outro, como ser pleno de dignidade e direitos, é condição para a celebração de uma cultura dos direitos humanos, inspirada pela observância do "mínimo ético irredutível", alcançado por um universalismo de confluência (PIOVESAN, 2010).

A laicidade estatal frente os fundamentalismos religiosos apresenta-se como o segundo repto à efetivação, uma vez que o Estado laico é garantia essencial para o exercício dos direitos humanos, especialmente nos campos da sexualidade e da reprodução. Confundir Estado com religião implica a adoção oficial de dogmas incontestáveis, que inviabilizam qualquer projeto de sociedade aberta, pluralista e democrática. A ordem jurídica em um Estado Democrático de Direito não se pode converter na voz exclusiva da moral de qualquer religião. Os grupos religiosos têm o direito de constituir suas identidades em torno de seus princípios e valores, contudo não detêm o direito de pretender hegemonizar a cultura de um Estado constitucionalmente laico ${ }^{10}$. (PIOVESAN, 2010).

${ }^{9}$ Estados Partes: Argentina, Brasil, Paraguai, Uruguai (desde 26 de março de 1991) e Venezuela (desde 12 de agosto de 2012). Estado Parte em Processo de Adesão: Bolívia (desde 7 de dezembro de 2012). Estados Associados: Chile (desde 1996), Peru (desde 2003), Colômbia, Equador (desde 2004), Guiana e Suriname (ambos desde 2013).

10 À luz dos sistemas regionais de proteção dos direitos humanos, importa ressaltar a existência de três sistemas (europeu, interamericano e o africano) e incipientes iniciativas de criação de sistema árabe e asiático. É no contexto do islamismo e dos países árabes que a tensão entre laicidade estatal e fundamentalismo religioso ganho 
E, por último, o respeito à diversidade frente à difusão de um discurso intolerante, entendido como o terceiro desafio, de modo que o processo de violação dos direitos humanos alcança prioritariamente os grupos sociais vulneráveis (mulheres, negros, homossexuais, índios, entre outros), que carecem de uma igualdade, destacando-se, assim, duas vertentes no que tange à concepção da igualdade: a igualdade formal, reduzida à fórmula "todos são iguais perante a lei" e a igualdade material, correspondente ao ideal de justiça enquanto reconhecimento de identidades. Como afirma Santos (1996, p. 34), "temos o direito a ser iguais quando nossa diferença nos inferioriza; e temos o direito a ser diferentes quando a nossa igualdade nos descaracteriza".

Contudo, diversos outros aspectos influenciam um ambiente não favorável à concretização da inclusão social dos historicamente excluídos, como a globalização, a segurança internacional e as políticas neoliberais. A partir deste contexto, é que se mostra imprescindível a necessidade de buscar caminhos para a implementação e concretização dos direitos humanos, para que ingressem nas mais diversas práticas sociais, sendo capazes de fomentar os processos de democratização a partir do empoderamento de cada comunidade local.

As razoes que tem inspirado a formação dos blocos comerciais integrados foram sintetizadas pelos mesmos autores uruguaios desta forma: interesses de ampliar os mercados nacionais, substituição da produção nacional, com importação de produtos a preços menores e acesso a recursos naturais não existentes no país (razoes econômicas) e ampliação do poder de negociação frente a terceiros países ou mesmo bloco de países e promoção de cooperação política regional (razoes políticas) (DEL'OLMO, 2001, p. 146, grifo no original).

Portanto, segundo Sine (1994) a educação em direitos humanos floresce como consequência de uma educação popular, onde há uma vocação para construir um projeto inolvidável, uma vontade mobilizadora definida por uma opção orientada à modificação estrutural e ao acordo com os setores populares da sociedade. Isso marcará desconexões com visões educativas neutras e com outras que não partilham as mesmas escolhas. Assunto a ser estudado no próximo tópico.

\section{EDUCAÇÃO EM DIREITOS HUMANOS: UMA PROPOSTA EMANCIPADORA}

Diante dos inúmeros desafios do futuro, sejam eles a diminuição da pobreza, da exclusão social, das incompreensões, das guerras, entre outros, floresce a educação como sendo um método imprescindível para que a humanidade tenha a possibilidade de lograr êxito na concretização de ideais como a paz, a liberdade e a justiça social, com o principal intuito de promover um desenvolvimento humano mais harmonioso e autêntico (UNESCO, 2010).

Neste contexto, a educação pode ser compreendida como uma declaração de amor para com a infância e a juventude, que devem ser acolhida em nossa sociedade, reservando-lhes o espaço que, sem dúvida, lhes cabe no sistema educacional e também no seio da família, da comunidade de base e da nação. Tendo esse dever de promover a educação em todos os ambientes, inclusive nas tomadas de decisão de ordem política, econômica e financeira: parafraseando o poeta, a criança é o futuro do homem (UNESCO, 2010).

A educação, de acordo com Saviani (1998) é algo inerente à própria condição humana, pelo fato de que desde que o homem vive em sociedade, ele desenvolve-se através da educação. Para conseguir sobreviver, o homem necessitou adaptar-se à natureza e transformá-la segundo as suas necessidades, o que se configura num verdadeiro processo de aprendizagem. Com o amadurecimento, o conhecimento foi sendo sistematizado e determinou a necessidade de mecanismos de transmissão e divulgação. Ainda segundo Peces-Barba (2007), a educação é um dos principais mecanismos para conscientização acerca da importância dos direitos, do seu significado e também do seu alcance, lembrando que a Declaração Universal dos Direitos Humanos afirma que entre as causas de desrespeito e ofensas aos direitos humanos está o desconhecimento.

Do ponto de vista jurídico, a educação pode ser conceituada a partir do pressuposto de que ela é um direito de personalidade, ou seja, como afirmado anteriormente, que decorre da simples existência do ser humano. É um direito amplo, que vai além da liberdade de aprendizagem, caracterizando-se como direito 
social, uma vez que pode ser exigido que o Estado crie os serviços públicos para atendê-lo. Ademais, o direito à educação é um direito subjetivo absoluto, intransmissível, irrenunciável e inextinguível (MACHADO JR, 2003).

Entende-se, portanto, que a educação é fundamental para o exercício dos direitos humanos, pois "é o recurso que as sociedades dispõem para que a produção cultural da humanidade não se perca, passando de geração a geração". Através dela, os seres humanos garantem a perpetuação do seu caráter histórico. Paro afirma que a "democracia não pode ser imaginada sem a atualização histórico-cultural de seus cidadãos, proporcionada pela educação, posto que ela mesma é um valor construído historicamente a ser apropriado pelos indivíduos" (PARO, 2000, p. 11).

Deste modo, o marco do reconhecimento da importância da educação como método transformador do ser humano remete às primeiras sociedades politicamente organizadas, quando a educação dirigia-se única e exclusivamente à formação de indivíduos de classes dominantes. Ao passo de que somente em meados do século XVI é que se dá início ao processo da universalização da educação, após grandes transformações na sociedade, é que a educação "vai ocupar papel de destaque no interesse e na preocupação de intelectuais e políticos, que passam a considerá-la como a ferramenta única para transformar a natureza humana no sujeito exigido pelos novos tempos" (GORCZEVSKI, 2009, p. 213).

Como consequência deste avanço na área da educação, começa-se também a questionar o papel da religião frente à secularização dos conteúdos, visto que o monopólio dos processos educacionais ainda se concentrava nas mãos dos grandes conglomerados religiosos. Apesar deste rápido avanço, somente nas primeiras décadas do século XX é que vão surgir as primárias referências à educação como direito, neste mesmo momento tem-se o surgimento do Estado Social, caracterizado pela intervenção do Estado na vida do ser humano.

Sobre este assunto, Gorczevski (2009, p. 216, grifo no original) assevera que a criação de sistemas públicos de educação, "extensivos" a todas as camadas sociais da sociedade e sua obrigatoriedade somente ocorreu com o nascimento do Estado Social - especialmente no pós Segunda Guerra Mundial, "quando os Estados, principalmente os mais desenvolvidos, começam a destinar um elevado percentual dos investimentos públicos para cobrir os gastos com a educação, cumprindo assim este compromisso social. Desde então, com avanços e recuos, tem se mantido como direito social e dever do Estado em oportunizála".

Neste cenário, para a Unesco (2010) a educação aparece como uma das chaves de acesso ao século XXI, ao superar a distinção tradicional entre educação inicial e educação permanente, dando resposta ao desafio desencadeado por um mundo em rápida transformação; tal constatação, porém, não constitui uma novidade já que relatórios precedentes sobre a educação sublinhavam a necessidade de um retorno à escola para enfrentar as novas situações que ocorrem tanto na vida privada quanto na vida profissional. Além de permanecer atual, essa exigência tornou-se ainda mais premente; e para superá-la, impõe-se que cada um aprenda a aprender.

Neste sentido, a educação como um mecanismo emancipador do ser humano pode ser compreendida na atualidade a partir de seus quatro pilares. Tendo como primeiro o aprender a conviver, baseado no desenvolvimento do conhecimento a respeito dos outros, de sua história, tradições e espiritualidade. E a partir daí, criar um novo espírito que, graças precisamente a essa percepção de nossa crescente interdependência e a uma análise compartilhada dos riscos e desafios do futuro, conduza à realização de projetos comuns ou, então, a uma gestão inteligente e apaziguadora dos inevitáveis conflitos. Eis algo que, para alguns, pode parecer uma utopia que não deixa de ser necessária - inclusive, vital - para sair do ciclo perigoso alimentado pelo cinismo ou pela resignação (UNESCO, 2010).

O segundo pilar pode ser conceituado como o aprender a conhecer, quando considera as rápidas alterações suscitadas pelo progresso científico e as novas formas de atividade econômica e social, é inevitável conciliar uma cultura geral, suficientemente ampla, com a possibilidade de estudar, em profundidade, um reduzido número de assuntos. Essa cultura geral constitui, de algum modo, o passaporte para uma educação permanente, à medida que fornece o gosto, assim como as bases, para aprender ao longo da vida (UNESCO, 2010).

Neste contexto, o aprender a fazer, classificado como o terceiro pilar da educação, ultrapassa a aprendizagem continuada de uma profissão, convém adquirir, de forma mais ampla, uma competência que torne o indivíduo apto para enfrentar numerosas situações, algumas das quais são imprevisíveis, além de facilitar o trabalho em equipe que, atualmente, é uma dimensão negligenciada pelos métodos de ensino. Essa competência e essas qualificações tornam-se, em numerosos casos, mais acessíveis se os alunos e os 
estudantes têm a possibilidade de submeter-se a testes e de enriquecer-se tomando parte em atividades profissionais ou sociais, simultaneamente aos estudos (UNESCO, 2010).

E, por último, finalizando o circulo dos fundamentos da educação, o aprender a ser, onde no século XXI, todos serão obrigados a incrementar a capacidade de autonomia e de discernimento, acompanhada pela consolidação da responsabilidade pessoal na realização de um destino coletivo. E também não deixar inexplorado nenhum dos talentos que, à semelhança de tesouros, estão soterrados no interior de cada ser humano. Sem ser exaustivo, pode-se citar a memória, o raciocínio, a imaginação, as capacidades físicas, o sentido estético, a facilidade de comunicar-se com os outros, o carisma natural de cada um... Eis o que confirma a necessidade de maior compreensão de si mesmo (UNESCO, 2010).

Assim, tendo por base estes fundamentos de uma educação emancipadora, evocou-se ainda outra utopia: a sociedade educativa baseada na aquisição, atualização e utilização dos conhecimentos. Com o desenvolvimento da sociedade da informação e a multiplicação das possibilidades de acesso a dados e fatos, a educação deve permitir que todos possam coletar, selecionar, ordenar, gerenciar e utilizar esse volume de informações e servir-se dele (UNESCO, 2010).

Com diversos instrumentos internacionais apontando para a importância da educação em direitos humanos, o Estado brasileiro adotou, em 1996, o Plano Nacional de Educação em Direitos Humanos (PNEDH), tendo como principal objetivo identificar e superar os obstáculos para a promoção e a defesa desses direitos no âmbito nacional. Sendo assim, o PNEDH tem por objetivo a criação e efetivação de políticas públicas educacionais voltadas para a conscientização dos direitos humanos para que no futuro tenha-se uma sociedade incentivadora da inclusão social, do respeito às diferenças, enfim, todas as formas de concretização de uma justiça social para o aprimoramento do Estado Democrático de Direito (GORCZEVSKI, 2009)

Entretanto, o reconhecimento da importância da educação voltada aos direitos humanos cresce no Brasil desde o a promulgação da Resolução no 1/2012 do Conselho Nacional de Educação, que estabelece as Diretrizes Nacionais para a Educação em Direitos Humanos e evidenciou-se que tal diploma tem por objetivo central "a formação para a vida e para a convivência, no exercício cotidiano dos Direitos Humanos como forma de vida e de organização social, política, econômica e cultural nos níveis regionais, nacional e planetário".

Portanto, a educação em direitos humanos não se resume ao processo de desenvolvimento da capacidade intelectual de cada indivíduo, vai muito além, tem a ver principalmente com a capacidade intelectual e moral do ser humano. (FERREIRA, 2001). Portanto, reconhecer a educação como vínculo de emancipação do sujeito para o exercício da sua cidadania é o maior desafio para os membros da sociedade que labutam pela ética enquanto pilar da condição humana, no encontro da humanização.

Dos estudos mais importantes realizados por Foucault (VAZ, 2004), talvez o mais essencial e primordial para a educação seja a expressão e a desconstrução feita sobre o sujeito desde sempre aí. Ao longo de suas obras, dedicou-se a averiguar não apenas a constituição da noção de sujeito, que é própria da modernidade, mas também de que maneira essa entidade torna-se sujeito moderno, isto é, como se autoconstitui (VEIGA, 2004). Em outros termos, questionou como se dá a constituição do sujeito moderno, que foi mais uma das invenções da modernidade, dada pela necessidade de legitimação do exercício do poder, enquanto se quer um indivíduo que produza e que permaneça na normalidade.

De qualquer modo, a noção de sujeito já estava sempre dada, partia da incompletude, por exemplo, para Kant incompleto porque ainda vazio; para Marx incompleto porque era alienado e inconsciente da realidade política e social. E segundo Piaget incompleto porque cognitivamente ainda não estava desenvolvido. Essa incompletude evidencia a importância da educação na constituição do sujeito. Vale lembrar que o sujeito desde sempre aí é visto como um objeto das influências sociais, culturais, políticas, educacionais e, por isso, facilmente manipulável (VAZ, 2004).

Ao encontro desse entendimento, para que a educação deixe de ser instrumental, pela característica atual de alienante por ser reprodutora de discursos, o homem precisa autodescobrir-se e compreender que a sua emancipação dar-se-á quando aceitar o outro como legítimo na relação social. Por esse motivo o amor é o elemento constitutivo da vida humana e, por sua vez, do processo de educar. (MATURANA, 1998). No mesmo sentido, Bauman (1999) afirma que uma sociedade realmente autônoma é feita de indivíduos autônomos, isto é, um indivíduo autoconstituído, que não recebeu pronta a sua identidade, que ao construí-la assume a responsabilidade por ela e, portanto, uma maneira de trabalhar essa identidade é pela educação. 
Contudo, a educação como propulsora da emancipação do sujeito - uma educação em direitos humanos, enfrenta diversos desafios em uma sociedade globalizada, na perspectiva do parto doloroso de uma sociedade mundial, ela situa-se, mais do que nunca, no âmago do desenvolvimento da pessoa e das comunidades; sua missão consiste em permitir que todos, sem exceção, façam frutificar seus talentos e suas potencialidades criativas, o que implica, por parte de cada um, a capacidade de assumir sua própria responsabilidade e de realizar seu projeto pessoal (UNESCO, 2010).

Logo, a igualdade sempre figurou no âmbito da homogeineização e padronização de uma só cultura comum, monocultural, vez que todos possuem os mesmos direitos e garantias de acesso, quando deveríamos, conforme Candau (2006, p. 234) "promover uma educação para o reconhecimento do 'outro', para o diálogo entre os diferentes grupos sociais e culturais. Uma educação para a negociação cultural".

Pierucci (1999, p. 7, grifo no original) é contundente em sua fala ao questionar se todos somos iguais ou somos todos diferentes? Queremos ser iguais ou queremos ser diferentes?

Houve um tempo que a resposta se abrigava segura de si no primeiro termo da disjuntiva. Já faz um quarto de século, porém, que a resposta se deslocou. A começar da segunda metade dos anos 70 , passamos a nos ver envoltos numa atmosfera cultural e ideológica inteiramente nova, na qual parece generalizarse, em ritmo acelerado e perturbador, a consciência de que nós, os humanos, somos diferentes de fato [...], mas somos também diferentes de direito. É o chamado "direito à diferença", o direito à diferença cultural, o direito de ser, sendo diferente. The right to be different!, como se diz em inglês, o direito à diferença. Não queremos mais a igualdade, parece. Ou a queremos menos, motiva-nos muito mais, em nossa conduta, em nossas expectativas de futuro e projetos de vida compartilhada, o direito de sermos pessoal e coletivamente diferentes uns dos outros".

Assim, o momento atual em que a humanidade encontra-se, diante de tantos infortúnios causados por guerras, criminalidade e subdesenvolvimento, hesita entre a aceleração do processo, sem ter a possibilidade de controlá-lo, e a resignação, pede-se outra saída. Neste contexto, acredita-se ser a educação voltada aos direitos humanos um processo de autoconhecimento e a consciência do meio ambiente, assim como a construção de capacidades que permitam orientar a ação de cada um, como membro de uma família, cidadão ou como um produtivo membro da sociedade, ao construir um sistema mais flexível (UNESCO, 2010).

Deste modo, a educação pensada é aquela que deva permitir que cada um venha a tomar consciência de si próprio e de seu meio ambiente, sem deixar de desempenhar sua função na atividade profissional e nas estruturas sociais. Assim, de acordo com a Unesco (2010) nada pode substituir o sistema formal de educação que, a cada um, garante a iniciação às mais diversas disciplinas do conhecimento; nada pode substituir a relação de autoridade, tampouco o diálogo entre professor e aluno. Eis o que tem sido afirmado e repetido por todos os grandes pensadores clássicos que se debruçaram sobre os problemas da educação. Portanto, incube ao professor transmitir ao aluno tudo o que a humanidade já aprendeu acerca de si mesma e da natureza, além do que ela tem criado e inventado de essencial.

Portanto, a educação em direitos humanos deve estar comprometida com a formação de cidadãos livres, críticos, responsáveis e comprometidos com a sociedade na qual vivem e da qual fazem parte, sem deixar de lado a história da humanidade.

\section{CONCLUSÃO}

A educação em direitos humanos está inserido em um movimento internacional de luta pela efetivação dos direitos humanos no mundo inteiro, mas principalmente no seara do Mercosul. Um movimento social histórico real, que possui uma linguagem, uma abrangência, uma articulação, uma organização que ultrapassa as fronteiras dos Estados, sejam elas horizontais ou verticais. Portanto, não se pode deixar somente nas mãos dos Estados e dos governos a imprescindível difusão e concretização dos direitos humanos.

Portanto, ao analisar a história dos direitos humanos e seus reflexos no plano internacional e regional atual, a situação das políticas públicas de educação em direitos humanos, o presente estudo buscou a reflexão sobre a necessidade de implementação de uma verdadeira política de educação em direitos humanos a ser implantada no país, para que os direitos humanos sejam, efetivamente, uma realidade. 
Educação essa capaz de desenvolver, cultivar, não de maneira unilateral, mas de forma integrada, para que o educando possa ser o cidadão honrado que todos desejamos encontrar na sociedade da qual fazemos parte. E para que se atinja esse grandioso objetivo será preciso, antes de tudo, uma conjugação de forças entre Estado, família e população, a fim de que se logre êxito na implementação de tão essencial política pública.

\section{REFERENCIAS}

[1] Barcelos, Ana Paula de. A eficácia jurídico dos princípios constitucionais: 0 principio da dignidade da pessoa humana. Rio de Janeiro: Renovar, 2002.

[2] Bauman, Zigmunt. Em Busca da Política. Rio de Janeiro: Jorge Zahar, 1999.

[3] Del'olmo, Florisbal de Souza. O Mercosul e a nacionalidade: estudo à luz do direito internacional. Rio de Janeiro: Forense, 2001.

[4] Dhesca, Plataforma. Direito Humano ao Meio Ambiente. Marijane Lisboa (relatora); Juliana Neves Barros (assessora). Inesc - Curitiba, 2008.

[5] Ferreira, Aurélio Buarque de Holanda (Org.). Mini Aurélio Século XX: o minidicionário da língua portuguesa. 4. ed. Rio de Janeiro: Nova Fronteira, 2001.

[6] Gorczevski, Clovis. Direitos humanos, educação e cidadania: conhecer, educar, praticar. 1. ed. Santa Cruz do Sul: Edunisc, 2009.

[7] Machado JR, César Pereira da Silva. O direito à educação na realidade brasileira. São Paulo: LTr 2003.

[8] Maturana, Humberto. Emoções e linguagem na educação e na política. Belo Horizonte: Ed. Ufmg, 1998.

[9] Mercosul. Página brasileira do Mercosul. Saiba mais sobre o Mercosul. Disponível em: <www.mercosul.gov.br/index.php/saiba-mais-sobre-o-mercosul>. Acesso em: 30 out 2015.

[10] Paro, Vitor Henrique. Por dentro da Escola Pública. São Paulo: Xamã, 2000.

[11] Peces-Barba, Gregório. Educación para la ciudadanía y derechos humanos. Madrid: Editorial Espasa Calpe, 2007.

[12] Pierucci, Antonio Flavio. Ciladas da diferença. São Paulo: Editora 34, 1999.

[13] Piovesan, Flávia. Direitos humanos e o direito constitucional internacional. São Paulo: Saraiva, 2010.

[14] Saldanha, Roberto Suarez. O individuo como sujeito de direito dotado de capacidade processual internacional para reclamar ofensas aos direitos humanos no sistema regional americano de proteção dos direitos humanos. In: Lobato, A. C.; Londero, J. C.; Dantas, R. R. (Orgs.). Direito e Cidadania. Juiz de Fora: Editar, 2006.

[15] Santos, Boaventura de Souza. Pela mão de Alice - social e o político na pós-modernidade. São Paulo: Cortez, 1996.

[16] Sarlet, Ingo Wolfgang. A Eficácia dos Direitos Fundamentais. 8. ed. Porto Alegre: Livraria do Advogado, 2007.

[17] Saviani, Dermeval. A nova lei da educação: trajetória, limites e perspectivas. Campinas: Autores Associados, 1998.

[18] Sime, L. Educacion, Persona y proyecto Histórico. In: Magendzo, A. (Org.) Educación en Derechos Humanos: apuntes para una nueva práctica. Chile: Corporación Nacional de Reparación y Reconciliación e PIIE, 1994.

[19]

nesco; Organização das Nações Unidas para a Educação, a Ciência e a Cultura. Educação, um tesouro a descobrir: Relatório para a Unesco da Comissão Internacional sobre Educação para o século XXI. Brasília, 2010.

[20] Vaz, Paulo. Risco e justiça. In: Calomeni, T. C. B.; et al. (Org.) Michel Foucault: entre o murmúrio e a palavra. Campos, Rio de Janeiro: Faculdade de Direito de Campos, 2004.

[21] Veiga, Neto Alfredo. Foucault e a educação. 2. ed. Belo Horizonte: Autêntica, 2004.

[22] Wolkmer, Antonio Carlos. Integração e direito comunitário latino-americano. In: Pimentel, Luiz Otávio (Org.). Mercosul no cenário internacional: direito e sociedade. Curitiba: Juruá, 1998, p. 43-54. 


\section{Capítulo 5}

Uma abordagem dos direitos da personalidade e os direitos do natimorto

\section{Gleicemeri de Vito Monaro \\ Fabíola Cristina Carrero \\ Paulo Henrique Pavolak}

Resumo:As garantias fundamentais e os direitos da personalidade constituem em importantes direitos conquistados, precisam fazer jus no meio social, resguardando os direitos do sujeito desde a concepção até a morte. Objetiva-se por meio dessa pesquisa bibliográfica abordar os direitos da personalidade, suas características e seu processo histórico, ressaltando os direitos do natimorto que são resguardados mesmo após o óbito, pois a eles não abrangem direitos patrimoniais, mas possuem outros direitos que precisam se respeitados. A metodologia adotada é através de pesquisa bibliográfica pautados nas leis, doutrinas e jurisprudências. Conclui-se que, esses direitos da personalidade são de suma importância para os estudiosos do direito, magistrados, família e a sociedade como um todo, e a medicina, a área civil e penal possuem suas contribuições para que esses direitos possam ser protegidos. São relevantes pesquisas científicas diante do tema abordado, para que possam aprimorar melhor os profissionais do direito, para que atuem com justiça diante do caso concreto.

Palavras-Chave: Contribuições; Direitos; Justiça; Natimorto.

Trabalho apresentado no X EPCC Encontro Internacional de Produção Científica, realizado no período de 24 a 26 de outubro de 2017, por meio do Centro Universitário de Maringá - UNICESUMAR. 


\section{INTRODUÇÃO}

O ser humano pouco a pouco veio conquistando seu espaço no meio social, algo que épocas passadas eram outra realidade apresentando uma evolução histórica, com o avanço da sociedade o direito foi sendo aprimorado e conquistado dia a dia, as garantias e direitos pessoais foram sendo incorporados e adquirindo relevância social ao meio jurídico. Deste modo, vários costumes e crenças foram sendo positivas no Direito Positivo e se tornando uma garantia à comunidade se transformando em leis e sendo uma garantia fundamental aos cidadãos, pois o direito é mutável e se molda conforme as necessidades da sociedade.

Diante desse exposto, a lei maior como outros ramos do direito tutelam essa proteção fundamental a vida do sujeito e expõe punições a quem a elas desacatarem conforme estão expressos, e não devem violar a dignidade da pessoa humana. Assim sendo, os direitos da personalidade presentes em leis extravagantes é uma dos grandes benefícios conquistados em todo esse lapso temporal, protegendo diversas ações vivenciadas no cotidiano tais como: a honra, a imagem, à vida, a liberdade intelectual, à intimidade sexual e outros, estendendo no que tange a integridade física, moral e intelectual dos indivíduos.

Objetiva-se por meio desse estudo ressaltar os direitos da personalidade, suas características e o processo histórico das garantias, esclarecendo que, embora o indivíduo venha a óbito no parto ou pós- parto terá direitos da personalidade, embora não abrange a sucessão, terá alguns direitos a serem resguardados, e a medicina, a área civil e penal também contribuem para resguardar esses direitos. A justificativa dessa pesquisa se pauta que, os direitos da personalidade são fundamentais no meio social não apenas aos estudiosos do direito, magistrados, mas a família, a sociedade pra que tenham discernimento dos direitos que possuem, pois não se pode alegar desconhecimento das normas legais. A metodologia adotada será através de pesquisas bibliográficas por meio de estudos realizados por doutrinadores e pesquisadores, pautando-se nas leis, doutrinas e jurisprudência.

\section{MATERIAL E MÉTODOS}

Distante de obter toda a complexidade dos direitos da personalidade, objetivamos por meio da pesquisa adentrar através de um aprofundamento teórico diante dos conceitos dos direitos da personalidade com enfoco nos direitos do natimorto que, embora não obtenha direitos patrimoniais, mas possuem aqueles que precisam ser resguardados como garantias fundamentais, sendo este, o objeto de análise desta pesquisa. A metodologia utilizada nesta pesquisa foi à pesquisa bibliográfica utilizando pesquisas já realizadas do tema, leis, doutrinas e jurisprudência.

A relevância dessa pesquisa configura-se na importância de estudos que demonstrem os direitos da personalidade que o natimorto possui mesmo que o nascimento não seja com vida, mas o corpo morto possui direitos que precisam ser respeitados na sociedade. Os conteúdos apresentados direcionam para maiores estudos diante desses direitos que possibilitem o aprofundamento de estudos e metodologias de ação, esclarecendo os direitos da personalidade a toda a comunidade e auxiliando aos estudiosos do direito referente ao objeto de análise, com finalidade de explanar os direitos da personalidade com ênfase no natimorto não apenas aos estudiosos do direito, mas também aos familiares e a comunidade em geral, possibilitando assim, o discernimento dos direitos que possuem e o seu cumprimento no meio social.

\section{RESULTADOS E DISCUSSÃO}

O direito da personalidade surgiu no século XIX, sendo manifestado pelo Otto Von Gierke, embora a proteção à pessoa humana tenha tido suas primeiras considerações com os gregos e romanos. Mas, o cristianismo caracterizou em grande influência para o surgimento da proteção ao ser humano, ao proclamar a relação do homem com Deus, assim por meio dessas considerações romperam certas concepções políticas dos romanos perante o conceito de pessoa pautados no status libertatis, civitatis e família (LEITE, 2006).

Os direitos da personalidade conquistaram um importante espaço no meio social e no âmbito jurídico, tornou-se um direito legalmente expressos na Lei maior sendo constitucional e a ofensa a eles acarreta elemento caracterizador de dano moral e patrimonial indenizável. Desde a antiguidade, os direitos da personalidade eram tutelados onde puniam com ofensas físicas e morais à pessoa em Roma e na Grécia, mas recentemente é visto como um direito subjetivo (DINIZ, 2014). 
Esse avanço histórico teve grande influência de dois marcos importantes, provenientes de duas tradições: o cristianismo e a declaração dos direitos no fim do século XVIII. O cristianismo exalta o indivíduo como ser único, que possui valor absoluto independentemente de suas condições, distinguindo o mesmo da coletividade e com livre arbítrio, e a declaração dos direitos sendo substrato para que pudesse proporcionar a libertação de vários homens de diversas limitações que eram expostas ao sistema feudal. Assim sendo, preparou-se um novo ambiente econômico, cultural e político, surgindo assim, o Estado de direito (DONEDA, 2005).

Mas, o que alavancou a defesa dos direitos individuais e a valorização da pessoa humana e sua liberdade cidadã com maior intensidade foi com a Declaração dos direitos em 1789, e após a Segunda Guerra Mundial no qual, através das diversas agressões ocasionadas por meio dos governos totalitários à dignidade humana, reconheceu-se e obteve uma maior conscientização da relevância dos direitos da personalidade para o meio jurídico, resguardando-se na Assembleia Geral da ONU de 1948, Convenção Europeia de 1950 e no Pacto Internacional das Nações Unidas (DINIZ, 2014).

Portanto, O Código Civil e a Constituição Federal posteriormente deram ênfase aos direitos da personalidade por meio das leis extravagantes tutelando esses direitos, e qualquer desacato diante desses, será punido o sujeito que ocasionar situações discriminatórias e atentatórias aos direitos e liberdades fundamentais (DINIZ, 2014).

Os direitos da personalidade constituem em direitos absolutos do indivíduo, que adquirem ao nascimento com vida e são extintos com a morte do cidadão. Esses direitos nada mais são do que deveres jurídicos de todos os membros da sociedade, sendo próprio da pessoa, fazendo assim parte da personalidade do titular. É importante ressaltar que, os direitos são inúmeros e estão prescritos na lei maior, cujo modo, deve ser cumprido conforme a legislação em vigor, tendo assim proteção constitucional (WALD, 2002).

Amaral (2000) afirma ainda que, a personalidade do sujeito nada mais é do que, um agrupamento de princípios e regras que concede proteção ao ser humano seja em seus aspectos e manifestações diante da sociedade. Deste modo, os direitos da personalidade estão presentes a partir do art. 1 do Código Civil, tendo como foco os valores essenciais do ser humano, em seus vários aspectos sejam eles: físico, moral e intelectual.

A Constituição Federativa Brasileira após 1988 fundou-se como Estado democrático de direito, onde após esses anos, o objetivo principal é a dignidade da pessoa humana, sendo o ser humano o objetivo fundamental da ordem jurídica. Destarte, a Constituição assim, recusa quaisquer atos praticados que venha expor o ser humano em situação desagradável, desconsideração, desigualdade perante os outros cidadãos ou até mesmo priva-lo de suas condições, pois constituem em amparo legal da norma (NOBRE JUNIOR, 2000).

Embora a personalidade e a capacidade, serem muito próximas entre si, são importantes termos a distinção entre ambas, pois não se caracterizam em sinônimos, personalidade é os direitos do indivíduo que são exercidos no decorrer de sua vida, já a capacidade é a autonomia de exercer esses direitos, tendo lhes aqueles que são impedidos pela lei de seu exercício, como os absolutamente incapazes e relativamente incapazes (AMARAL, 2000).

Assim sendo, o autor acima nos esclarece sobre:

Enquanto a personalidade é um valor, a capacidade é a projeção desse valor que traduz em um quantum. Pode-se ser mais ou menos capaz, mas não se pode ser mais ou menos pessoa. Compreende-se assim, a existência de direitos da personalidade, não os direitos da capacidade. 0 ordenamento jurídico reconhece a personalidade e concede a capacidade, podendo considerar-se esta um atributo daquela (AMARAL, 2000, p. 216).

Conforme esse pressuposto, o ordenamento jurídico nos proporciona os direitos da personalidade, e ao possuirmos ele pautados na lei, poderemos exercê-los ou não, dependerá do que a lei nos dizer. Vale mencionar que, o direito protege e garante aos cidadãos sua reprodução e conservação diante da sociedade, como o princípio que ressalta sua dignidade humana.

Os direitos da personalidade não são sujeitos à transferência de um indivíduo ao outro, ou seja, caracterizam em direitos inerentes á dignidade humana, assim sendo, são inalienáveis, intransmissíveis, imprescritíveis e irrenunciáveis. Destarte, o indivíduo não pode conceder direitos de sua personalidade para outrem que não o tenha como: direito á vida, à liberdade física ou intelectual entre outros (RODRIGUES, 2003). 
Diniz (2014) complementa e exemplificam com maiores detalhes os direitos de personalidade, estes possuem determinadas características que devem ser expostas para a compreensão, pois são direitos absolutos pelo fato de serem oponíveis a efeito erga omnes, não são transmissíveis pelo fato do sujeito não poder dispor, transferindo total ou parcial esfera jurídica a outrem, quaisquer que seja o sujeito e a situação vivenciada por ele.

Destarte, esses direitos da personalidade nascem com o sujeito titular e com ele é extinto, sendo inseparáveis. Haja vista, os direitos da personalidade são indisponíveis em via de regra, mas possui um respaldo na lei admitindo a disponibilidade do direito em casos em prol do interesse público, pois este deve prevalecer diante do privado (DINIZ, 2014).

Vale ressaltar que, os direitos da personalidade independem de uma relação familiar para ser caracteriza um direito, assim tanto em relações interna dos familiares ou da relação dos familiares com outros indivíduos da sociedade, são permitidos os direitos de sua personalidade. Deste modo, os direitos são indeterminados, sendo alguns desses direitos: a igualdade e a liberdade, constituição de família ou dissolução da mesma, direito a privacidade, ao nome, direito à moradia entre outros (DELGADO, 2016).

Vale mencionar que, os direitos da personalidade são passíveis de serem defesos frente à integridade física (direito à vida, direito ao corpo vivo, direito ao corpo morto), integridade intelectual (à liberdade de pensamento, de autor, de inventor, de esportista, de esportista participante de espetáculo público) e integridade moral (à liberdade civil, à honra, à honorificência, à intimidade, à moral, ao recato, ao aspecto moral da estética humana, à identidade pessoal, familiar e social, ao segredo pessoal, doméstico, profissional, político e religioso, a identidade sexual entre outros (DINIZ, 2017).

A personalidade jurídica tem seu início com o nascimento com a vida a partir do instante que ocorreu a sua respiração, mesmo que momentânea e que não prossegui por horas ou dias, mas segundos já considera que o mesmo nasceu com vida. Deste modo, embora aparentemente não demonstre relevância o nascimento e após instantes o óbito do feto para alguns, para o direito das sucessões esta ação é de suma relevância e merece uma enorme cautela, pois envolve a transmissão de bens patrimoniais, mesmo que o indivíduo não esteja mais em vida, e embora seja natimorto possui direitos da personalidade.

Vale ressaltar que, trata-se de um ato relevante para o direito, envolvendo interesses na área civil como o direito da personalidade, o direito das sucessões relacionadas ao caso concreto. Desde modo, é preciso que especialistas possam comprovar verdadeiramente o nascimento com vida ou a ausência constatando cientificamente, por meio da entrada de ar em seu pulmão, com essa entrada estará comprovada sua respiração (DINIZ, 2014).

Entretanto, mesmo que o recém-nascido não teve respiração e batimentos cardíacos, ele terá direitos. Vale ressaltar que, independentemente da criança nascer com vida ou não, deverá ser registrada, pois o registro de nascimento caracteriza em uma instituição pública com fins em identificar os cidadãos, concedendo o exercício dos direitos inerentes a ele (DINIZ, 2014).

Portanto, o foco a ser esclarecido não é a questão hereditária, embora tenha a influência da atuação do direito e do ordenamento jurídico, mas caso o sujeito nasça com vida ou ausência dela, e mesmo sendo natimorto terá direitos da personalidade quanto a sua honra, nome, imagem, sepultura, mas não proveniente ao direito das sucessões.

A teoria natalista, é a teoria adotada pelo ordenamento jurídico e pela doutrina tradicional, do qual a personalidade inicia com o nascimento com vida, pois antes do nascimento não há personalidade, mas ressalva-se, direitos ao nascituro desde a sua concepção (RODRIGUES, 2003).

0 natimorto caracteriza-se no feto que nos procedimentos provenientes ao nascimento, são expelidos pelo seio materno sem vida, não tendo indícios de respiração em seus pulmões. Embora seja uma situação traumática e entristecedora para os pais e familiares, é extremamente verídico na sociedade e o ordenamento jurídico protege seus direitos e os concedem direitos da personalidade mesmo frente ao luto fetal.

Brasil (2009) define natimorto:

Natimorto ou óbito fetal: é a morte do produto da gestação antes da expulsão ou de sua extração completa do corpo materno, independentemente da duração da gravidez. Indica o óbito o fato de, depois da separação, o feto não respirar nem dar nenhum outro sinal de vida como batimentos do coração, pulsações do cordão umbilical ou movimentos efetivos dos músculos de contração voluntária (BRASIL, 2009, p. 25). 
Rodrigues (2009) menciona que, a sensação da perda de um filho é dolorosa e causa impacto vasto tanto a mãe, pai e afeta todos os membros da família, algo inesperado que abala integralmente á área emocional e afetiva dos envolvidos.

Vale ressaltar que, diante da realidade enfrentada é preciso que todo o nascimento ocorrido no território nacional deverá ser registrado, mesmo que o feto seja um natimorto ou venha a óbito logo após o parto. Assim sendo, deverá ser registrado no Livro "C auxiliar" respeitando os elementos arrolados no art. 54 da lei № 6.015/73 em caso de natimorto, e se a morte for por ocasião do parto, deverá realizar dois registros: o de nascimento e o de óbito (DINIZ, 2014).

Diante dos aspectos fundamentais da personalidade, os direitos ao corpo morto são garantidos a ele e protegidos pelo ordenamento jurídico, dos quais estão interligados com o direito à integridade física. Assim sendo, embora não tenha a personalidade civil merecem respeito a família e a sociedade, estando protegidos alguns direitos tais como: ao sepulcro, à cremação, à utilização científica, relativos ao transplante e ao culto religioso (DINIZ, 2017).

Consequentemente, nada mais justo e idôneo frente aos pais e familiares do natimorto, pois diante de uma situação desagradável e infelizmente dolorosa a família, o mínimo que a sociedade precisa demonstrar diante da perda, é o respeito, embora ocorra situações que violam esse bem jurídico, um exemplo claro são os crimes cometidos contra os mortos.

A polêmica muitas vezes pode estar na evidência ao natimorto em questões que envolvem a sucessão hereditária, pois o natimorto pode ter sido proveniente de uma expulsão materno sem indícios de vida ou por poucos instantes ter nascido com vida e vir a óbito em seguida. O que ocasiona a dúvida é a concretização dessa afirmação de que, realmente nasceu morto ou não. Assim sendo, a medicina constatase por meio de exames clínicos denominado tradicionalmente como docimasia hidrostático de galeno, provando o verdadeiro ocorrido de maneira profissional e clínica (GONÇALVES, 2003).

Haja vista, é essencial destacar que, esse exame é apenas um dos adotados na sociedade para esse fim, mas como a medicina vem inovando e está cada dia mais avançada, existem outros exames mais modernos e eficazes que produzem o mesmo efeito, até mesmo por meio de outros órgãos do corpo além da constatação dos pulmões do indivíduo (GONÇALVES, 2003).

Deste modo, esse exame clínico pode gerar inúmeras polêmicas e discussões por familiares, no que tange ao direito das sucessões, pois ao gerar um natimorto, ele terá direitos provenientes a sua honra, imagem, sepultamento não abrangendo a herança, mas caso nascer e logo após morrer, o sujeito obteve direitos hereditários que devem seguir a ordem hereditária (GONÇALVES, 2003).

Assim sendo, Brasil (2002) expõe a ordem hereditária a ser cumprida, em caso de falecimento para a correta transmissão hereditária, expresso no art. 1829 do Código Civil:

Art. 1.829. A sucessão legítima defere-se na ordem seguinte:

I - aos descendentes, em concorrência com o cônjuge sobrevivente, salvo se casado este com o falecido no regime da comunhão universal, ou no da separação obrigatória de bens (art. 1.640, parágrafo único); ou se, no regime da comunhão parcial, o autor da herança não houver deixado bens particulares;

II - aos ascendentes, em concorrência com o cônjuge;

III - ao cônjuge sobrevivente;

IV - aos colaterais (BRASIL,2002).

Consequentemente, é relevante ter conhecimento diante da compreensão do natimorto ou nascituro, pois em ambos os casos definirá a ordem de herança aos seus pais ou familiares neste caso, e a medicina apresenta suma importância para a comprovação do verdadeiro nascimento e direito no que tange as sucessões.

Prerrogativa importante que não deve ser esquecida, é que a transmissão de herança está relacionada aos direitos de sucessões, e sua verdadeira transmissão não é admitida em vida, mas apenas após o falecimento, onde a morte caracteriza um fato jurídico que a herança só será obtido pelos herdeiros com o óbito. Esclarece ainda que: "A morte natural é o cerne de todo o direito sucessório, pois só ela determina à abertura da sucessão, uma vez que não compreende sucessão hereditária sem o óbito do de cujus, dado que não há herança de pessoa viva" (DINIZ, 2017, p. 34). 
Em caso de perda e danos perante a violação dos direitos da personalidade, permanece em discrepância do juiz na análise do caso concreto, se determinada ação acarreta lesão ou não, e se o mesmo fato caracteriza-se em perdas e danos. Analisando-se no caso concreto, violado esses direitos previstos no ordenamento jurídico e comprovadas em juízo, terá a vítima os direitos afirmados no art. 12, assim entendem-se tanto a norma em vigor como a jurisprudência, sendo este fato confirmado por meio do processo № TST-RR-201300-36.2008.5.02.0039, onde o juiz concedeu-lhe o provimento a vítima, que teve direitos da personalidade lesionado pelo empregador (MELLO FILHO, 2016).

Consequentemente, o surgimento desses direitos pautados no ordenamento jurídico, devem ser tutelados pois se trata de um valor intrínseco ao ser humano e interligado com a sua dignidade (ROCHA; DIAS, 2015).

Recurso Especial. civil. Processual Civil. Ação Indenizatória Por Dano Moral. Parto Gemelar. Um Natimorto. Desaparecimento do Cadáver. Responsabilidade do Nosocômio pela Guarda dos Restos Mortais. Impossibilidade de Sepultamento. Ofensa Moral. Valor da Reparação. redução. Cabimento. Embargos Declaratórios na Apelação. Multa por Litigância de Má-Fé. Afastamento. Recurso Parcialmente Provido. Recurso Especial № 1.351 .105 SP (2012/0226484-7)

Assim sendo, é cabível o dano moral pelo fato de ter gerado mais tristeza, angústia e dor a família, pois o desaparecimento do corpo fetal gerou mais dano aos familiares pelo sepultamento impossível de ser realizado, conforme a própria fundamentação jurídica do recurso ressalta a violação dos direitos da personalidade.

Permanecem claro que ouve a violação desses direitos, os aspectos fundamentais da personalidade e foram violados no respectivo caso concreto anteriormente, pelo fundamento de que, um dos direitos garantidos ao corpo morto é o sepulcro, não sendo possível essa ação pelos familiares, pela ausência do corpo fetal (DINIZ, 2014).

A Constituição Federal Brasileira (1988) reconhece que os direitos do natimorto foram violados, desacatando a norma jurídica constitucionalmente, conforme expresso no art.1, Inciso III:

Art. 1ํ A República Federativa do Brasil, formada pela união indissolúvel dos Estados e Municípios e do Distrito Federal, constitui-se em Estado Democrático de Direito e tem como fundamentos:

I - a soberania;

II - a cidadania;

III - a dignidade da pessoa humana;

IV - os valores sociais do trabalho e da livre iniciativa;

V - o pluralismo político.

Parágrafo único. Todo o poder emana do povo, que o exerce por meio de representantes eleitos ou diretamente, nos termos desta Constituição (BRASIL, 1988).

Perante da situação entristecedora para a família, poderão reclamar diante da lesão sofrida, conforme a lei os protege, dando amparo diante do Código Civil, art. 12:

Art. 12. Pode-se exigir que cessasse a ameaça, ou a lesão, a direito da personalidade, e reclamar perdas e danos, sem prejuízo de outras sanções previstas em lei.

Parágrafo único. Em se tratando de morto, terá legitimação para requerer a medida prevista neste artigo o cônjuge sobrevivente, ou qualquer parente em linha reta, ou colateral até o quarto grau (BRASIL, 2002). 


\section{CONCLUSÃO}

As garantias fundamentais e os direitos da personalidade foram importantes conquistas almejadas e protegidas por todo o ordenamento jurídico. Desta forma, devem ser tutelados e resguardados esses direitos por toda a sociedade, e a violação dos mesmos, acarretará sanções pois a conduta contrária a lei, lesiona a integridade do sujeito e sua dignidade humana.

Diante do exposto nesta pesquisa, são informações importantes para o conhecimento dos estudiosos do direito, magistrados, familiares e toda a comunidade pois, muitos desconhecem os direitos que possuem desde a concepção, pois os direitos patrimoniais são adquiridos a partir do nascimento com vida extinguindo com a morte, mas vários outros direitos são inerentes a pessoa mesmo que ainda seja feto, nascituro ou natimorto. Vale ressaltar que, esses conhecimentos relevantes não possuem apenas a influência de entendedores do direito, mas a medicina também desempenha importante atuação na comprovação do nascimento com vida por meio do avanço com exames clínicos para a devida comprovação, a área civil e penal também auxiliam significativamente, na civil com o registro do nascimento ou natimorto e a área criminalista nas punições penais nos que envolvem crimes contra esses bens resguardados, tais como: à vida, ao sentimento religioso, ao corpo morto e outros.

Portanto, é de suma relevância que as pesquisas envolvendo os direitos da personalidade e as garantias fundamentais sejam mais difundidas na sociedade por meio de estudos científicos, palestras e cursos aos acadêmicos do direito e profissionais da área jurídica. Além disso, demonstrar aos estudiosos do direito a importância de sua atuação para que possa fazer a justiça ao caso concreto, para isso, é necessário que tenham discernimento do tema abordado, interpretação das leis, doutrinas e jurisprudência para atuar adequadamente diante do caso.

\section{REFERÊNCIAS}

[1] Amaral, Francisco. Direito civil: introdução. 3 ed. Revista aumentada e atualizada. Rio de janeiro: Renovar, 2000.

[2] Brasil. Constituição Federativa Brasileira. Diário Oficial da União. Brasília, Out, 1998.

[3] Brasil. Lei № 10.406 de 10 de Janeiro de 2002. Código Civil. Diário Oficial da União: Brasília, Jan, 2002.

[4] Brasil. Ministério da Saúde. Manual de vigilância do óbito infantil e fetal e do comitê de prevenção do óbito infantil e fetal. Brasília: Ministério da Saúde, 2009.

[5] Delgado, Mário Luiz. Direito da personalidade nas relações de família, 2016. Disponível em: <http://www.ibdfam.org.br/_img/congressos/anais/34.pdf>. Acesso em: 23 Maio. 2016.

[6] Diniz, Maria Helena. Curso de direito civil brasileiro: direito das sucessões. 31 ed. São Paulo: Saraiva, 2017.

[7] Diniz, Maria Helena. Curso de direito civil brasileiro: teoria geral do direito civil. 31 ed. São Paulo: Saraiva, 2014.

[8] Doneda, Danilo. Os direitos da personalidade no código civil. Revista da faculdade de direito dos campos, v. 1, n. 6, p. 71-99, 2005. Disponível em: <http://fdc.br/Arquivos/Mestrado/Revistas/Revista06/Docente/03.pdf>. Acesso em: 23 Maio. 2016.

[9] Gonçalves, Carlos Roberto. Direito civil brasileiro: parte geral. São Paulo: Saraiva, 2003.

[10] Leite, Carlos henrique bezerra. Os direitos da personalidade na perspectiva dos direitos humanos e do direito constitucional do trabalho. Revista Brasileira de Direito Constitucional, v. 2, n. 7, p. 343-354, 2006. Disponível em: <http://esdc.com.br/seer/index.php/rbdc/article/view/344/337>. Acesso em: 23. Maio. 2016.

[11] Mello Filho, Vieira. Processo № TST-RR-201300-36.2008.5.02.0039. Poder Judiciário. Justiça do trabalho Tribunal Superior do trabalho, 2016.2 Disponível <http://jurisprudencia.s3.amazonaws.com/TST/attachments/TST_RR_2013003620085020039_e0cc9.pdf?Signature =ycKecug5pPVu0vX2TQqZhBMMoac\%3D\&Expires=1464092628\&AWSAccessKeyId=Akiaipm2xemzacaxcmba\&respo nse-content-type=application/pdf\&x-amz-meta-md5-hash=22060fcd8e43e34243a3d088a17a2560>. Acesso em: 24 Maio. 2016.

[12] Nobre Junior, Edilson Pereira. 0 direito brasileiro e o princípio da dignidade da pessoa humana. R. Dir. adm, v. 1, n. 1, p. 237-251, 2000. Disponível em: <http://bibliotecadigital.fgv.br/ojs/index.php/rda/article/view/47505/45250>. Acesso em: 27 Maio. 2016.

[13] Recurso Especial № 1.351.105 - $\quad$ SP $\quad$ (2012/0226484-7). Disponível em: <https://ww2.stj.jus.br/processo/revista/documento/mediado/?componente=ATC\&sequencial=29236924\&num_reg istro=201202264847\&data=20130620\&tipo=5\&formato=PDF>. Acesso em: 20 Jul. 2017. 
[14] Rocha, Maria Vital da; DIAS, Eliza Cristina Gonçalves. Direitos para além da vida: a possibiidade de testar sobre diretos da personalidade. RJLB, v. 1, n. 1, p. 1635-1651, 2015. Disponível em: <http://cidp.pt/publicacoes/revistas/rjlb/2015/1/2015_01_1635_1651.pdf>. Acesso em: 24 Maio. 2016.

[15] Rodrigues, Márcia Maria Coelho. A experiência da mãe por ter um filho natimorto, 2009. Disponível em: <http://www.teses.usp.br/teses/disponiveis/7/7141/tde-11012010-144032/en.php>. Acesso em: 12 Jul. 2017. [dissertação de mestrado]

[16] Rodrigues, Silvio. Direito Civil: parte geral. 33 ed. São Paulo: Saraiva, 2003.

[17] Wald, Arnoldo. Direito civil: introdução e parte geral. 9 ed. Rev. ampl. e atual. São Paulo: Saraiva, 2002. 


\title{
Capítulo 6
}

\section{Controle social e serviço social: Breve abordagem sobre a participação social no Conselho Municipal de Saúde}

\author{
Thais Tavares Bernardo \\ Luciane Cordeiro da Silva Mosca
}

Resumo: 0 presente trabalho se propõe a apresentar uma breve abordagem sobre a participação social e a relação de poder entre Estado e sociedade civil, no espaço de controle social no campo da saúde, a partir de uma pesquisa qualitativa realizada no âmbito do Conselho Municipal de Saúde de Campos dos Goytacazes e as possíveis contribuições do Serviço Social.

0 termo "controle social" permeia toda a história da humanidade, estando mais presente em nosso cotidiano do que podemos imaginar. Correia (2008, p. 104) descreve que, o controle social seguiu durante muitos anos como instrumento favorecedor a um tipo de "ordem social" exercida dentro dos conflitos de classes e gerado na relação de poder do Estado sobre a sociedade civil.

Nos Art. no 196-197 da Constituição Federal de 1988, fica evidenciado o direito a todos a uma saúde com acesso universal e igualitário, e de dever do Estado em promover a universalização com ações e serviços de promoção, proteção e recuperação da saúde. E, são de relevância a regulamentação, fiscalização e controle de todas as ações e serviços de saúde, através do exercício do controle social pela sociedade civil e outras instâncias públicas e privadas (BRASIL, 2013, p. 138).

Neste contexto, abrem-se possibilidades dos representantes dos usuários, enquanto conselheiros, participarem das formulações e da execução de políticas de saúde nos municípios, visando discutir e contribuir para o bem-comum da sociedade. Esta participação é considerada uma conquista da população usuária da saúde, como expresso na Constituição de 1988, em que descreve a participação popular enquanto direito social. Participação que deve ser seguida de acordo com as diretrizes organizativas do SUS e sobre os critérios estabelecidos pelo CMS, para o exercício do controle social (LIRA, 2012, p. 42-48).

Assim, abordamos as percepções do Serviço Social vinculado a efetivação da participação social como mecanismo de transformação da realidade social, seguido dos princípios de igualdade e liberdade perpassando o caráter reivindicatório de direitos e de busca por democracia para uma participação popular que contribua nos processos decisórios e de execução da política de saúde, ou seja, consideramos a participação social como a melhor forma da sociedade se relacionar com as questões públicas na luta por garantia de direitos.

Palavras-chave: Política de Saúde; Serviço Social; Participação Social. 


\section{ATUAÇÃO DO SERVIÇO SOCIAL E O EXERCÍCIO DO CONTROLE SOCIAL}

As sucessivas transformações que a Política de Saúde percorreu no Brasil, tem a $8^{\mathrm{a}}$ CNS como o marco para toda evolução ocorrida na área da saúde do país. Nela, trataram não somente temáticas de cunho sanitarista como muitos cogitam, mas também discussões que naquele momento deram base para construção da seção - Da Saúde na Constituição de 1988, promulgada posteriormente e, consequentemente a universalização do acesso à saúde descrito no SUS e na própria $\mathrm{CF} / 88$, onde determina em seu Art. 196 que, a saúde é direito de todos e dever do Estado, garantido mediante políticas sociais e econômicas que visem à redução do risco de doença e de outros agravos e ao acesso universal e igualitário [...] (BRASIL, 2013a, p. 138).

Conforme o CNS (1986, p. 70), quando um governo adota a saúde para todos se compromete a fomentar o progresso de todos os cidadãos em uma ampla frente de desenvolvimento e está resolvido a estimular a cada cidadão para conseguir uma melhor qualidade de vida.

Na 8 a CNS foram trabalhados três eixos: 1) saúde como direito; 2) reformulação do Sistema Nacional de Saúde; e 3) financiamento do setor, criando a partir dessa ênfase, o caminho para a construção do SUS e para organização e gestão da saúde descentralizada com apoio da administração dos estados e municípios. No Art. no 198 da CF/88, é determinado que as ações e serviços de saúde sejam integrados em uma rede (regionalizada e hierarquizada) de sistema único e que sigam as seguintes diretrizes: $I$ - descentralização, com direção única em cada esfera de governo; II - atendimento integral, com prioridade para as atividades preventivas, sem prejuízo dos serviços assistenciais; III - participação da comunidade (BRASIL, 2013a, p. 138).

Assim, os estados e municípios se tornam entes fortalecidos e ganham a responsabilidade da gestão da política pública de saúde em todo seu território, contando com a participação da sociedade nos espaços dos CMS, sob a forma representativa de entidades, organizações e setores públicos e privados.

Destacamos que o primeiro CMS do Brasil foi constituído no Município de Volta Redonda/RJ, em 1985 e, atuou um ano através do Decreto no 200 de 1967. Teve sua estabilidade não somente com a $8^{\text {a }}$ CNS, realizada em 1986, como também após promulgação da CF/88. Posteriormente, novas leis e, mais recentemente, com Resoluções e Decretos, que definiram ajustes e normatizações para os Conselhos de Saúde, trouxeram consigo legalidade e relevância para existência dos CMS. Cabe, a partir desses fatos, conhecer a finalidade por trás da criação dos CMS.

Neste sentido, Lira (2012, p. 5) sinaliza que com o processo de descentralização da gestão da saúde, tornou necessária a ampliação na administração da política de saúde por meio dos Conselhos de Saúde em esfera federal, estadual e municipal, dando maior autonomia e eficácia a essa administração. Portanto, o CMS além de ser classificado como órgão colegiado, deliberativo e de caráter permanente, instância em que seus membros têm poderes iguais, é determinado pela Resolução no 333/2003 como órgão paritário, em que determina que o número de elementos (representantes) seja igual para evitar diferenças ou injustiças.

Gohn (2003, p 30-32) afirma que o período da trajetória da criação dos CMS rompe os antigos paradigmas da gestão pública e política do Brasil que, anteriormente ficava a cargo de uma parcela da elite tradicional que ascenderam ao governo. A partir deste cenário, houve o aprofundamento da democratização representativa em que a sociedade civil se torna peça importante nos desdobramentos referentes aos assuntos de gestão das políticas públicas na instância do CMS.

Para que um Conselho de Saúde seja estabelecido no município, deve seguir o critério de representatividade paritária, descrito na Resolução no 453 da seguinte forma:

I - O número de conselheiros será indicado pelos Plenários dos Conselhos de Saúde e das Conferências de Saúde, devendo ser definido em Lei. II - Mantendo ainda o que propôs a Resolução $n^{\circ}$ 33/92 do CNS e consoante as recomendações da $10^{\underline{a}} e$ da 11 a Conferências Nacionais de Saúde, as vagas deverão ser distribuídas da seguinte forma: a) $50 \%$ de entidades de usuários; b) $25 \%$ de entidades dos trabalhadores de saúde; c) 25\% de representação de governo, de prestadores de serviços privados conveniados, ou sem fins lucrativos. (BRASIL, 2012b)

Assim, o critério de paridade representativa dentro dos CMS, parte da representação em números iguais, onde os segmentos de usuários detêm $50 \%$ dessa representação, os segmentos dos trabalhadores de saúde, dos segmentos do governo e prestadores de serviços privados, conveniados ou sem fins lucrativos 
detêm os outros 50\%, e juntos atuam nas formulações, controle, fiscalização e execução dos serviços de saúde distribuídos em todo o território do município.

Os CMS's tem papel de mediador das relações políticas entre o governo e a população usuária da saúde e, juntamente com a participação comunitária tem-se a possibilidade de criar e assegurar políticas públicas que supram as necessidades de toda a sociedade ali representada.

Nessa perspectiva Gohn (2003, p. 85-88) descreve que:

Os conselhos gestores são novos instrumentos de expressão, representação e participação; em tese, eles são dotados de potencial de transformação política. Se efetivamente representativos, poderão imprimir um novo formato às políticas sociais, pois se relacionam ao processo de formação das políticas e tomada de decisões. [...] Eles criam uma nova esfera social-pública ou pública não-estatal. Trata-se de um novo padrão de relações entre Estado e sociedade, porque eles viabilizam a participação de segmentos sociais na formulação de políticas sociais e possibilitam à população o acesso aos espaços nos quais se tomam decisões políticas.

Os CMS instituídos em todo território nacional passa por um tipo de medição determinada pelo seu porte. A avaliação em que os conselhos são submetidos segue o critério em escala proporcional ao seu nível populacional, ou seja, ao seu número de habitantes. 0 município de Campos dos Goytacazes, local do estudo em questão, segundo IEGM Brasil (2015), tem sua população estimada de 483.970 habitantes e com a área territorial de $4.026 .696 \mathrm{~km}^{2}$. Portanto, de acordo com a análise do IEGM, o município de Campos dos Goytacazes localiza-se na categoria de grande porte, por seu número de habitantes ser maior que 200.000. Compreende-se então, que Campos dos Goytacazes é o munícipio do estado que tem maior condição de imprimir qualidade de vida a sua população e, entre os 92 municípios contidos em todo o território de abrangência do Estado do Rio de Janeiro, obtêm a maior faixa territorial do estado.

O CMS de Campos dos Goytacazes está localizado a Rua Voluntários da Pátria, no 187 - Centro. Este fica aberto ao público de segunda à sexta-feira, com atendimento nos horários das 08 às 17 horas. As reuniões ordinárias são realizadas toda 1a terça-feira de cada mês, às 19 horas e as extraordinárias com prévio agendamento da data e horário para sua realização. Para que se realizem as reuniões e plenária no CMS, deve ser levado em conta o quórum simples (quantidade mínima obrigatória de membros presentes ou formalmente representados, para que uma assembleia possa deliberar e tomar decisões válidas) que na Resolução no 453/2012, este quórum pode se constitui em três formatos; mínimo, especial ou qualificada.

Assim, Brasil (2012b) inscreve os quóruns da seguinte forma:

VIII - as decisões do Conselho de Saúde serão adotadas mediante quórum mínimo (metade mais um) dos seus integrantes, ressalvados os casos regimentais nos quais se exija quórum especial, ou maioria qualificada de votos; a) entende-se por maioria simples o número inteiro imediatamente superior à metade dos membros presentes; b) entende-se por maioria absoluta o número inteiro imediatamente superior à metade de membros do Conselho; c) entende-se por maioria qualificada 2/3 (dois terços) do total de membros do Conselho; [...].

Deste modo, os CMS foram instituídos, de certa forma, para prestar contas ao Tribunal de Contas dos Municípios - TCM, Tribunal de Contas dos Estados - TCE, Tribunal de Contas do Distrito Federal - TCDF e ao Tribunal de Contas da União - TCU. Alguns municípios têm TCM, mas no caso do Município de Campos dos Goytacazes, este, presta contas ao TCE/RJ e, ao TCU em casos extremos, entendendo assim, que a administração da saúde, a partir dos conselhos gestores, adere uma conduta sob o senso ético-legal.

A presença dos assistentes sociais aparece no CMS de duas formas. A primeira forma se dá por meio do próprio conselho, que propicia ao profissional a função de fiscalizador e auditor, em visitas a hospitais e entidades participantes representadas no CMS. A segunda forma, parte dos assistentes sociais que atuam como conselheiro ou suplente representando algum dos segmentos que compõe a estrutura representativa do CMS de Campos dos Goytacazes. Deste modo o CFESS (2012, p. 31) sinaliza que,

Os desafios presentes no campo da atuação exigem do(a) profissional o domínio de informações, para identificação dos instrumentos a serem acionados e requer habilidades técnico-operacionais, que permitam um profícuo diálogo com os diferentes segmentos sociais. $O$ conhecimento da realidade possibilita o seu deciframento para "iluminar" a condução do trabalho a ser realizado. 
A partir dessa realidade pode-se entender que o profissional de Serviço Social atua como coadjuvante no espaço do CMS. De acordo com o Código de Ética da Profissão o assistente social deve manter uma postura que motive a transformação individual e coletiva da população usuária.

Barroco (2010, p. 171) descreve que o trabalho do assistente social se insere no contexto de contradição inerente ao mercado de trabalho no sistema capitalista, com a ideologia pregada pela classe dominante, que estabelece suas relações no valor das mercadorias, fomentando a "coisificação" das relações sociais. Nessa direção, o assistente social enfrenta os desafios oriundos desse contexto pautando o seu trabalho nas atribuições da profissão, e também no seu compromisso com o projeto ético-político, que deve orientar a forma de atuar nos diversos espaços de controle democrático.

Os CMS, no contexto do gerenciamento público da saúde nos Municípios, têm como sua principal importância ser um órgão de ligação direta com o SUS, além de ser uma instância de articulação e parceria com inúmeras autoridades públicas, entidades e associações civis. Nesse sentido, o CMS de Campos dos Goytacazes é considerado uma instância pública para manter o estreitamento do relacionamento da sociedade com o governo, por meio de uma abertura da participação comunitária nos processos de fiscalização dos recursos, acompanhamento e do andamento/execução dos serviços de saúde prestado dentro do Município.

Portanto, o CMS é considerado um dos principais canais de inclusão social referente à garantia do direito da população participar no controle e na elaboração de propostas para a gestão de saúde. Dentro do cenário da relação entre Estado e sociedade civil, necessita-se de profissional com competência para trabalhar o consenso entre as partes. Nessa perspectiva, Iamamoto (2011, p. 58) afirma que os assistentes sociais são:

[...] Sujeitos que acumulam saberes, efetuam sistematizações de sua "prática" e contribuem na criação de uma cultura profissional, historicamente circunscrita. Logo, analisar a profissão supõe abordar, simultaneamente, os modos de atuar e de pensar que foram por seus agentes incorporados, atribuindo visibilidade às bases teóricas assumidas pelo Serviço Social na leitura da sociedade e na construção de respostas à questão social.

A presença do assistente social no espaço de controle social favorece não somente o entendimento entre as partes composta pelos segmentos, como também para a melhor condução dos planos, programas e projetos de saúde desenvolvidos através do CMS. A partir do conhecimento profissional do assistente social, o CMS poderá ter seu desempenho considerado satisfatório, tendo em vista que os assistentes sociais, tanto em seu cotidiano profissional e como conselheiros, conduzem suas ações para solucionar e/ou amenizar o sofrimento da sociedade, e entendendo que esse também é o alvo dos gestores públicos que participam do conselho.

Portanto, para reconhecimento do exercício profissional do assistente social enquanto conselheiro, no espaço de controle social do CMS de Campos dos Goytacazes, foram recolhidas informaç̧ões relevantes em entrevistas realizadas com 01 (um) assistente social/conselheiro do segmento dos usuários e com 01 (um) assistente social/conselheiro do segmento de Formadores de RH.

Sobre a presença e experiências desses assistentes sociais que atuam como conselheiros no espaço de controle social, no CMS, os relatos foram os seguintes:

"[...] na atual posição em que me encontro dentro do Conselho de Saúde, não consigo nem mesmo expor minha opinião, quanto mais adotar qualquer tipo de estratégia para ampliação da participação dos usuários da política de saúde. [...]" (Assistente Social - conselheiro do segmento dos usuários - entrevista em 03/11/2017).

Trazem mais considerações sobre suas presenças nesse espaço:

"[...] foram feitas propostas de trabalho, mas nada foi adiante. Fizemos propostas desde leitura da ata, acesso aos documentos, que os documentos que fossem aprovados ficassem disponíveis para que todos os conselheiros pudessem ler, ter cópias, examinar, fazer grupos de estudos. Mas nada disso foi adiante" (Assistente Social - conselheiro do segmento Formadores de RH - entrevista em 27/11/2017).

A partir dessas declarações, podemos entender que a presença de conselheiros que tenham em sua formação a capacitação com "atribuições e competências" que permitam enxergar a realidade social de 
modo mais crítico, onde as ações desses passam do "simples" papel de compor uma mesa diretória ou mesmo de trabalhar em um local de decisões coletivas em benefício privado da organização a quem representa, possibilita uma atuação comprometida com a transformação social da área em que está envolvido. Desse modo, a presença de assistente social no CMS, atuando como conselheiro atribui ao mesmo crédito, esperando que as proposições ali firmadas sejam com a finalidade de satisfazer os interesses da coletividade. Sabendo que este profissional foi capacitado no campo político e social, entende-se que, enquanto conselheiro de saúde, este intenciona contribuir para a transformação da política pública em que atua, considerando os princípios éticos de sua formação e de acordo com suas competências e atribuições profissionais presentes em seus locais de atuação profissional.

Entre essas, na posição que o assistente social assume como conselheiro, podemos acentuar as seguintes:

I - elaborar, implementar, executar e avaliar políticas sociais junto a órgãos da administração pública, direta ou indireta, empresas, entidades e organizações populares; II - elaborar, coordenar, executar e avaliar planos, programas $e$ projetos que sejam do âmbito de atuação do Serviço Social com participação da sociedade civil; III - encaminhar providências, e prestar orientação social a indivíduos, grupos e à população; [...] $V$ - orientar indivíduos e grupos de diferentes segmentos sociais no sentido de identificar recursos e de fazer uso dos mesmos no atendimento e na defesa de seus direitos; [...] IX - prestar assessoria e apoio aos movimentos sociais em matéria relacionada às políticas sociais, no exercício e na defesa dos direitos civis, políticos e sociais da coletividade; [...] (BRASIL, 2012, p. 44- 45).

A diferença da presença de assistentes sociais como conselheiros nos CMS, parte basicamente do conhecimento que este profissional adquire em toda sua formação e de sua experiência com a realidade da social na qual se insere no desenvolvimento de sua prática profissional. Seu caráter mediador entre sociedade civil e Estado acaba sendo o ponto alto para que esteja nesse espaço representando a sociedade civil.

[...] a questão de credenciamento, não é um tema fácil, não é um domínio fácil, você tem que se dedicar, você tem que estudar, ao mesmo tempo você tem que trazer esse tema e traduzir para uma linguagem simples para os usuários, para que eles possam compreender como, Hospital tal, onde as crianças estão sendo internadas e estão morrendo? Porque esta instituição está credenciada? E o que envolve esta política?" (Assistente Social - conselheiro do segmento de Formadores de RH - entrevista em 27/11/2017).

Nos espaços dos CMS's, sua presença contribui para proporcionar abertura para que a sociedade civil ocupe o espaço que lhe é destinado, tanto para participação em todas as etapas de elaboração e efetivação da política de saúde no município, quanto para o controle social por meio do acompanhamento e fiscalização dos recursos que são dispostos para a saúde. Deste modo, a presença do assistente social em espaço de controle social, favorece não somente o entendimento entre as partes composta pelos segmentos representados, como também a melhor condução dos planos, programas e projetos de saúde desenvolvidos através dos CMS's.

A partir do conhecimento social que o profissional de serviço social dispõe, espera-se que os Conselhos de Saúde possam desempenhar o seu papel perante a população usuária com uma contribuição mais qualificada.

\section{PARTICIPAÇÃO SOCIAL: POSICIONAMENTO DO ASSISTENTE SOCIAL ENQUANTO CONSELHEIRO MUNICIPAL DE SAÚDE NA GARANTIA DO DIREITO PARTICIPATIVO}

Dentre as várias formas de participação social, exercidas pelos indivíduos na organização de uma sociedade, é possível destacar algumas que são encontradas no cotidiano dos brasileiros através dos seguintes espaços: audiências e consultas públicas, comitês gestores, mesas de diálogo, ouvidorias, planos diretores, orçamentos participativos, as conferências e os conselhos nacionais, estaduais e locais. 
Todos esses instrumentos foram institucionalizados muito recentemente. No governo do presidente Lula e da presidenta Dilma ${ }^{11}$, no âmbito da participação social foram estabelecidos a PNPS (Política Nacional de Participação Social) e o SNPS (Sistema Nacional de Participação Social), no ano de 2014, como meio de consolidar a participação social no país. No Art. 6o do Decreto no 8.243/2014, onde se institui a PNPS, são descritas como instâncias para efetivação da participação social: conselho de políticas públicas; comissão de políticas públicas; conferência nacional; ouvidoria pública federal; mesa de diálogo; fórum interconselhos; audiência pública; consulta pública; e ambiente virtual de participação social. As instâncias e mecanismos de participação social estabelecida a partir deste momento não eliminam a criação e reconhecimento das demais formas de diálogo entre Estado e sociedade civil, sendo que todas as apresentadas na PNPS seguem em seu Art. 3ํㅜㅇ as seguintes diretrizes:

\begin{abstract}
I - reconhecimento da participação social como direito do cidadão e expressão de sua autonomia; II - complementariedade, transversalidade e integração entre mecanismos e instâncias da democracia representativa, participativa e direta; III - solidariedade, cooperação e respeito à diversidade de etnia, raça, cultura, geração, origem, sexo, orientação sexual, religião e condição social, econômica ou de deficiência, para a construção de valores de cidadania e de inclusão social; IV direito à informação, à transparência e ao controle social nas ações públicas, com uso de linguagem simples e objetiva, consideradas as características e o idioma da população a que se dirige; V - valorização da educação para a cidadania ativa; VI - autonomia, livre funcionamento e independência das organizações da sociedade civil; e VII - ampliação dos mecanismos de controle social (BRASIL, 2014b).
\end{abstract}

Percebe-se assim, que o direito de participação social teve recentemente apoio legal para se manter ativa, mesmo frente aos diversos ataques para sua impraticidade. Deste modo, as novas regulamentações em torno da participação social, proporcionam a sociedade civil condições de expressão autônoma, ou por meio da representatividade, onde os mesmos ganham maior notoriedade e voz ativa diante das ações do Estado, possibilitando ajustes reais nas políticas públicas em discussão. A participação social em Conselhos e Conferências de Saúde acontece sob o critério de representação, com conselheiros e delegados devidamente eleitos, para verbalizarem diálogos entre representantes da sociedade civil e representantes do Estado. Esse tipo de participação é considerado por muitos autores/pesquisadores como a melhor forma de adequação das políticas públicas e atuação da sociedade civil no controle social, tendo como base de avaliação, quatro dimensões de experiências: 1) Inclusão; 2) Participação; 3) Debates; e 4) Conexões (PIRES, 2011, p. 284).

Nesse cenário conflituoso de interesse de ordem política e social, surgem atores para contribuir com as potencialidades dos segmentos sociais, no contexto da participação social em esfera pública. Os assistentes sociais, dentro de suas competências, orientam a sociedade na busca pela efetivação de seus direitos em virtude de consolidar o preconizado em leis e decretos. A atuação profissional na direção da ampliação e defesa dos direitos sociais segue o viés da manutenção desses direitos diante do cenário de retrocessos em que estão condicionados na atual conjuntura política. Bravo $(2009$, p. 6) apresenta que:

A participação dos sujeitos, entretanto, só poderá ser exercida mediante amplo trabalho de capacitação para que ocorra uma intervenção qualificada $e$ propositiva no sentido de exigir direitos e exercer formas de pressão sobre o poder público. Nas frações de classe com baixo poder de organização, as dificuldades são ainda mais complexas. Para que o controle democrático se efetive é necessário que os representantes da sociedade civil possam organizar-se institucionalmente nas suas bases e que tenham consciência dos seus direitos e a quem reclamá-los.

Assim, os assistentes sociais/conselheiros no CMS de Campos dos Goytacazes têm que lidar com situações de caráter propositivo, tanto trabalhando a necessidade do controle social com suas bases representativas quanto com seus usuários. Nesse sentido, em entrevista realizada com assistente social/conselheiro, atualmente representante do segmento dos usuários, e que anteriormente atuou pelo -segmento de Prestadores de Serviços na Área de Saúde, foi possível identificar algumas dificuldades na efetivação da participação social nas reuniões do CMS:

\footnotetext{
11 Governos que aconteceram no Brasil no período de 2003 a 2016: O Governo Lula (2003-2011) e o Governo Dilma Rousseff (2011-2016). Os dois foram reeleitos, mas, no caso da presidenta Dilma, seu 2o mandato de governo foi interrompido pelo processo de impeachment sendo destituída do posto em 31 de agosto de 2016.
} 
Desorganização comunitária, articulação dos conselheiros com suas bases, entrosamento dos conselheiros com a comunidade e desmobilização dos movimentos populares, são algumas das dificuldades mais presentes para a não participação popular nas reuniões do CMS. [...] A divulgação das reuniões acontece só por um veículo de difícil acesso a população usuária (Assistente Social - conselheiro do segmento dos usuários - entrevista em 03/11/2017).

Em entrevista realizada com a conselheiro/representante do segmento de Formadores de RH, não é visualizado nenhuma das alternativas apresentadas pelo entrevistado do segmento dos usuários. É descrito como dificuldade para o fortalecimento da participação social o seguinte fator:

Não há interesse do atual Conselho em novos movimentos populares, [...] não existe interesse por parte deles. Esse conselho não tem nenhum interesse que haja participação popular. Os conselheiros são os mesmos do governo anterior (Assistente Social - conselheiro do segmento Formadores de RH - entrevista em $27 / 11 / 2017)$.

A participação no CMS é a forma de expressão da vontade individual ou coletiva da sociedade, com o objetivo de contribuir com propostas de mudanças e de interferir positivamente nas tomadas de decisões junto ao poder público. A participação popular pode ser direta ou indireta. Na direta, o próprio cidadão está presente e se manifesta em diferentes níveis. Já na participação indireta, o cidadão não está presente e tem seu interesse representado por um interlocutor.

Os cidadãos dentro da história adquiriram a liberdade em sentido político-social, por meio da capacidade humana e das exigências éticas. Consideram que aos gregos couberam os primeiros passos da sistematização ética com a participação dos cidadãos na organização dos destinos da cidade e, assim materializando um cenário ético e político de decisão sem nenhum tipo de submissão, prevalecendo à prática da vontade autônoma, onde apresenta que o homem é um ser político e racional com capacidade de conhecimento para a vida pública, capaz de deliberar racionalmente (BARROCO, 2010, p. 100-101).

A palavra "representar" significa que alguém pode falar ou atuar em nome de uma pessoa ou de um grupo. Os representantes nos conselhos devem ser escolhidos de acordo com as atribuições assumidas enquanto profissionais no âmbito da política pública em que estão inseridos. Em entrevista ainda é afirmado que: $A$ desconstrução é muito mais eficaz do que a construção da mobilização social (Assistente Social - conselheiro do segmento de Formadores de RH - entrevista em 27/11/2017). Contudo, apesar dos interesses opostos dos segmentos representados pelos entrevistados, suas visões são praticamente idênticas por entenderem que a participação social é um direito que vem sendo desvirtuado num aparelho constituído para ser exercida a democracia participativa e o controle social.

Sobre esse assunto, Nosswitz (2008, p. 11-12) afirma que as inovações democráticas, a partir da CF/88, designam a participação democrática no estabelecimento dos conselhos setoriais de políticas sociais, sendo os conselhos paritários ou de direitos e de políticas públicas, concebidos como os novos canais para o exercício da participação social, na tentativa de se construir esferas públicas mais democráticas. A autora ainda aponta que são nesses canais que se ampliam as possibilidades de decisão, definição e controle das políticas públicas pela sociedade civil. Porém,

Os Conselhos e as Conferências não são as únicas formas de participar do SUS, embora sejam as únicas obrigatórias para todo o país, por serem previstas em lei Federal. A medida que se avança na democratização da gestão, outros mecanismos podem - e devem - ser criados nos estados e nos municípios para ampliar as possibilidades de participação e tornar, as decisões mais próximas da população. É o caso dos conselhos distritais e dos conselhos gestores nas unidades de atenção à saúde, já existentes em muitos municípios. (Brasil, 1994, p. 35-36).

Portanto, no que diz respeito ao direito da sociedade civil participar da chamada coisa pública, como é previsto em lei, depende do conhecimento dos mesmos sobre o assunto e do posicionamento de seus representes/conselheiros no CMS. A capacidade de articulação dos conselheiros de saúde com suas bases e os usuários refere-se ao nível de entrosamento adotado.

Nesse sentido, são relatados nas entrevistas os assuntos discutidos com mais frequência nas reuniões do CMS. Na visão do representante do segmento dos usuários os assuntos discutidos frequentemente são:

Política Municipal de Saúde; Convênios; Financiamento; e Serviços, mas nesse último, com a observação de que o mesmo serve para pactuar a compra em 
estruturas privadas de exames inexistentes na esfera pública (Assistente Social conselheiro do segmento dos usuários - entrevista em 03/11/2017).

Já na visão do representante do segmento de Formadores de RH, os assuntos partem basicamente dos:

Convênios e Financiamento. Pois, sobre as Conferências de Saúde é declarado que: A Conferência Municipal de Saúde, não foi feita. As duas últimas não foram feitas. Pode-se observar em termos de acesso as atas que, sobre a Conferência da Saúde da Mulher, entre outros, nada disso é discutido. Agora, os outros assuntos, tudo é citado, só para se ter em ata regimental aprovado, mas discutidos, não (Assistente Social - conselheiro do segmento de Formadores de RH - entrevista em 27/11/2017).

Dentre os relatos acima, é possível visualizar que os temas/assuntos tratados no CMS, estão muito mais condicionados aos interesses de parte de um grupo do que da coletividade. Fatores esses que proporcionam ao assistente social/conselheiro do CMS, um campo de intervenção de constantes desafios para alçar o caminho da mudança no cenário no qual se insere. Os Conselhos são apresentados por Bravo (2009, p. 3) como lócus do fazer político, como espaços contraditórios, orientados pela democracia participativa, tendo no horizonte a construção da democracia de massas. Assim,

o conselho pode ser organizado de uma forma itinerante para alcançar mais efetivamente a participação social, para isso basta ter boa vontade. Mas, não é que não sabem trabalhar dessa forma, [na verdade] não têm o interesse (Assistente Social - conselheiro do segmento de Formadores de RH - entrevista em 27/11/2017).

Devemos destacar que o posicionamento do assistente social, enquanto conselheiro municipal de saúde deve estar de acordo com suas competências e atribuições profissionais, em direção da garantia do direito participativo em uma instância de debates e consensos sobre o "bem comum" para a sociedade. Alguns dos princípios fundamentais que direcionam a profissão afirmam:

I. Reconhecimento da liberdade como valor ético central e das demandas políticas a ela inerentes - autonomia, emancipação e plena expansão dos indivíduos sociais; II. Defesa intransigente dos direitos humanos e recusa do arbítrio e do autoritarismo; III. Ampliação e consolidação da cidadania, considerada tarefa primordial de toda sociedade, com vistas à garantia dos direitos civis sociais e políticos [...]; IV. Defesa do aprofundamento da democracia, enquanto socialização da participação política e da riqueza socialmente produzida; $V$. Posicionamento em favor da equidade e justiça social, que assegure universalidade de acesso aos bens e serviços relativos aos programas e políticas sociais, bem como sua gestão democrática; [...] (BRASIL, 2012, p. 23).

Desse modo, as competências do assistente social são compatíveis aos desafios que irá encontrar no campo da saúde, incluindo também a sua atuação como conselheiro no CMS. Isso indica que é necessário o aprofundamento dos conhecimentos acerca das diretrizes que envolvem a atuação de um conselheiro na área da saúde para que todos os profissionais no campo da saúde que poderão ocupar os espaços dos Conselhos, inclusive para os estudantes de Serviço Social no período de formação acadêmica.

o processo de descentralização das políticas sociais públicas - com ênfase na sua municipalização - requer dos assistentes sociais, como também de outros profissionais - novas funções e competências. Estão sendo requisitados e devem dispor de competências para atuar na esfera da formulação e avaliação de políticas, assim como do planejamento e gestão, inscritos em equipes interdisciplinares que tensionam a identidade profissional (CFESS, 2012, p. 60).

Contudo, os limites colocados para a efetivação do exercício de suas funções de conselheiro no CMS, não devem ser nunca visto como obstáculos, mas sim como barreiras a serem rompidas. 0 que diferencia a atuação dos conselheiros em geral é o enfoque dado em seu posicionamento diante ao grupo que compõe o Conselho. Nesse sentido, espera-se que, os assistentes sociais, enquanto conselheiro, tenham uma bagagem de habilidades maior do que os demais conselheiros, referente ao reconhecimento da realidade social e da detenção dos melhores meios para intervenção social. Maria da Glória Gohn descreve algumas necessidades e lacunas no cenário dos conselhos gestores e aponta que: 
1 - Falta uma definição precisa das competências e atribuições desses conselhos e da sua relação com o poder Legislativo [...]; 2 - Deve-se cuidar da elaboração de instrumentos jurídicos de apoio às suas deliberações; 3 - Deve haver uma definição mais precisa do que seja participação. [...] (GOHN, 2002, p. 25).

A partir da promulgação da Constituição de 1988 no Brasil, foram criados espaços para que os movimentos sociais organizados coexistam junto ao poder público no desenvolvimento da gestão das políticas públicas. Esses espaços são conhecidos como Conselhos Gestores, e estão situados no campo político. Eles atuam em diversos campos, na saúde, educação, meio ambiente, entre outros. Assim, pode-se dizer que o Estado se completa com o apoio da participação da sociedade civil. Com a configuração do direito participativo que a sociedade ganha, ela pode manifestar suas ideias e interagir em deliberações que afetam a toda uma população. 0 dialogo nesses espaços é fundamental para a tomada de decisões, que venham impactar na qualidade dos serviços prestados. Em entrevista, o representante do segmento dos usuários esclarece sobre sua atual posição no CMS, onde declara:

No presente momento, não tenho oportunidade de me posicionar pelo fato de ser suplente e o conselheiro em que sou coligada não me permite opinar. Os suplentes só tem voz ativa em caso de falta dos conselheiros titulares (Assistente Social conselheiro do segmento dos usuários - entrevista em 03/11/2017).

Nessa percepção, pode ser afirmado que não há democracia sem participação social. Desse modo, a democracia participativa pode ser entendida pelo nível de envolvimento da sociedade civil com a política em seu sentido geral. A atuação dos conselheiros nos assuntos de caráter coletivo e o agir ético-político, contribui com a democracia participativa consideravelmente.

0 assistente social atuando como conselheiro na área da saúde tem duplo desafio. 0 primeiro desafio situa-se na forma de se posicionar no papel de conselheiro/representante, de um dos segmentos contemplados na formação do CMS. E, deste modo, sua atuação deve condizer com o que determina as funções de um conselheiro sem perder as características profissionais próprias do assistente social. 0 segundo desafio parte da conduta do assistente social em fazer uma junção de suas atividades de conselheiro com o que preconiza o Código de Ética da Profissão. Dessa forma,

[...] $O$ assistente social atuando em esfera das políticas sociais, das organizações e movimentos sociais, pode interferir, no âmbito de sua área de competência, para ampliar a ingerência de segmentos da sociedade civil em questões que lhes são concernentes, compartilhando propostas e decisões, contribuindo para romper as "caixas pretas" que guardam em segredo informações que necessitam ser difundidas junto à coletividade (IAMAMOTO, 2011, p. 79).

No cenário em que se encontram os CMS atualmente, não cabe ao assistente social se manter em posição ambígua em sua função, seja como conselheiro representante de algum segmento ou como profissional que atua diretamente com o conselho. Contudo, vale ressaltar que o assistente social a partir de seu processo de maturidade, vem rompendo com os paradigmas do clientelismo adotados no percurso histórico da política de saúde no país. Em direção a ampliar o conhecimento dos usuários acerca dos direitos a saúde, esses profissionais atuam orientando sobre onde e como acessá-los, possibilitando-lhes condições autônomas com empoderamento para lidarem com as diversas situações que deflagraram no campo político, conforme aponta uma profissional:

Em termos do Serviço Social, eu representando os Recursos Humanos, vejo que o tempo disponibilizado para o meu exercício de conselheiro anda num compasso que necessita de ajuste, pois é uma coisa que exige dedicação, construção" (Assistente Social - conselheiro do segmento de Formadores de RH - entrevista em 27/11/2017).

O Estado é conhecido por ter o poder de coerção em sua essência e a sociedade civil por necessitar das ações do Estado, ou seja, ter dependência de ações no caráter de políticas públicas. 
Seguindo o critério da Constituição de 88, o Estado tem a obrigação de promover os serviços de saúde e a sociedade tem o direito de participar ativamente em todos os processos desses serviços como forma de traduzir as reais necessidades sociais do grupo representado, com o objetivo de proporcionar soluções positivas.

[...] O assistente social é o profissional que trabalha com políticas sociais, de corte público ou privado e não resta dúvida ser essa uma determinação fundamental na constituição da profissão, impensável mais além da interferência do Estado nesse campo. Entretanto, as políticas sociais públicas são uma das respostas privilegiadas à questão social, ao lado de outras formas, acionadas para o seu enfrentamento por distintos segmentos da sociedade civil, que têm programas de atenção à pobreza, como as corporações empresariais, as organizações das próprias classes subalternas para fazer frente aos níveis crescentes de exclusão social a que se encontram submetidas (IAMAMOTO, 2011, p. 58).

O CMS, sendo um dos equipamentos mais sofisticado e bem estruturado para o exercício democráticoparticipativo, sugere que o Estado com a contribuição da sociedade civil discuta e articule mediações na direção do consenso nas tomadas de decisões voltadas para política de saúde. Isso só acontece pelo poder de representatividades alocado como um dos atributos dos segmentos que compõe os Conselhos de Saúde.

\section{CONTROLE SOCIAL ATRAVÉS DO CMS: CONTRIBUIÇÕES PARA AVANÇOS E MUDANÇAS NA POLÍTICA DE SAÚDE EM CAMPOS DOS GOYTACAZES}

Partindo do entendimento que o controle social contribui para avanços e mudanças no cenário da saúde, a criação dos conselhos de saúde em âmbito municipal se configura como um passo importante na história da saúde no Brasil, onde estabelece a democracia na gestão dos recursos financeiros destinados a investimentos na política de saúde, assim, dando ao município o poder de gerir e distribuir esses recursos com mais precisão com o apoio dos representantes do Estado e da sociedade civil, para que os investimentos nos serviços de saúde atendam às necessidades da população usuária. No que se referente aos CMS's, Bravo (2009, p. 2), esclarece que:

Importantes dispositivos foram definidos com relação à descentralização do poder federal e a democratização das políticas no sentido da criação de um novo pacto federativo, sendo o município reconhecido como ente autônomo da federação, transferindo-se para o âmbito local novas competências e recursos públicos capazes de fortalecer o controle social e a participação da sociedade civil nas decisões políticas.

O controle social nesse sentido acontece com o exercício da participação social e na democratização da gestão pública que, permite a sociedade organizada e os cidadãos intervirem no andamento das políticas públicas, interagindo com o Estado para definição de prioridades e para elaboração de planos dos municípios, estado e governo federal. Nessa nova configuração de gestão da saúde, sob a ordem de conselhos locais, os assistentes sociais, profissionais capacitados ao reconhecimento da realidade social, são representantes com condições de trabalhar em direção dos avanços e mudanças que necessita a política pública de saúde do município de Campos dos Goytacazes, visando assim, alcançar as necessidades da sociedade campista.

Os assistentes sociais como representantes da sociedade civil na instância do CMS, direta ou indiretamente, lutam em prol das classes sociais que ali estão representando, com intuito de proporcionar certa igualdade social dentro do contexto da política de saúde. Nesse sentido, Bravo (idem, p. 5) apresenta que:

Nesta direção, os profissionais adeptos do projeto ético-político da profissão precisam qualificar suas ações a fim de contribuírem para a ampliação de uma cultura política crítica e democrática necessária ao efetivo controle democrático dos sujeitos coletivos que buscam na arena pública - enquanto interlocutores e representantes dos interesses da maioria da população - defender a garantia dos direitos sociais, num cenário de regressão dos mesmos e de destruição das conquistas históricas dos trabalhadores.

Assim, para o assistente social se posicionar dentro do CMS, esse deve estar bem calçado em suas competências e atribuições em decorrência de ser ele um interlocutor dos interesses de uma parcela 
expressiva da sociedade, de forma que, numa arena de correlação de forças, entre Estado e sociedade civil, sua presença se torna fundamental nesse espaço em virtude de seu posicionamento que tende a fortalecer a sociedade. Para tanto, incentivar a participação social, garantindo que o direito participativo se efetive dentro do espaço do conselho de saúde, é tarefa proveniente do compromisso ético-político compatível com a formação profissional dos assistentes sociais, como forma de fortalecer o projeto ético-político do Serviço Social em um cenário de interesses contraditórios.

Em declaração dada pelos assistentes sociais/conselheiros do segmento dos usuários e de Formadores de $\mathrm{RH}$, podem ser observados que suas experiências partem de sua qualificação profissional e atuação em dois momentos distintos de representatividade.

Anteriormente representando o HPC, (segundo semestre do ano de 2008). E atualmente, desde 2016 por outro segmento [...] segmento dos usuários (Assistente Social - conselheiro do segmento dos usuários - entrevista em 03/11/2017). No âmbito da saúde atuo há 3 (três) anos. E no conselho de saúde há 1 (um) ano e meio. Pelo segmento de Formadores de Recursos Humanos (Assistente Social - conselheiro do segmento de Formadores de RH - entrevista em 27/11/2017).

Conforme a experiência em dois segmentos diferentes foi exposto pelo representante do segmento dos usuários que o desafio percebido em seu exercício como conselheiro no CMS encontrava-se:

Em romper com a estrutura de interesses privados, adotados pela maioria dos conselheiros, o que impede em larga escala o alcance do bem coletivo. De forma que quem adentra esse cenário, ou segue o ritmo ditado ou enfrentará a condição nula diante da maioria que compõe o Conselho (Assistente Social - conselheiro do segmento dos usuários - entrevista em 03/11/2017).

Deste modo, pode ser considerado que o assistente social enquanto conselheiro no CMS, tem dificuldades de contribuir para que a necessária mudança na área da saúde se realize devido à estrutura de interesses já posta, que favorece somente umas das partes e não ao bem coletivo, ali representado pelos vários segmentos.

Num sentido muito similar, são apresentados pelo representante do segmento de Formadores de RH os seguintes desafios:

A falta de transparência, o não acesso a informações essenciais da saúde e, também o que mais me dificultou foi o desconhecimento dos conselheiros em relação ao seu real papel de controle social. Conselheiros que não tem noção do que compete a eles enquanto conselheiros, e aí não desempenham corretamente o seu papel dentro do conselho, proporcionando vícios que já estão consolidados dentro do nosso Conselho Municipal de Saúde (Assistente Social - conselheiro do segmento Formadores de RH - entrevista em 27/11/2017).

A declaração acima sinaliza a falta de conformidade com as diretrizes impostas a um conselho gestor. Assim, Machado (2012, p. 109) apresenta que, o agir no local e no global, conhecer a realidade política, econômica, social e cultural é um dos passos importantes tanto para contribuir satisfatoriamente nas necessidades sociais quanto para o fortalecimento da organização popular, sendo o último uma exigência acerca da garantia do direito participativo. Dessa forma, a falta de clareza nos assuntos tratados no CMS, impossibilita a participação da sociedade no controle social e em virtude disso as transformações não ocorrem na direção que deveria. Assim,

Então tem uma complexidade que vai desde você compreender como é feito esse trabalho à você saber fiscalizar, pois também é papel dos conselheiros fiscalizar $e$ tudo mais, e como levar essas informações aos usuários. E você saber e ter o domínio desses assuntos é importante para que você tenha sua participação efetiva nas reuniões dos conselhos, para que você possa argumentar (Assistente Social - conselheiro do segmento de Formadores de RH - entrevista em 27/11/2017). 
Os modelos de gestão da saúde adotados a partir da criação dos CMS podem ser tidos como um dos maiores avanço na área da política de saúde, onde a comunidade ganha o direito de exercer a democracia participativa em âmbito local. 0 fato que destoa a configuração primaria dos CMS na maioria das vezes, é que esse direito ou é negado ou coibido.

Os conselhos de saúde, criados pela Lei no 8.142, de 1990 [...], tornaram-se o paradigma que inspirou a constituição recente de conselhos em outras áreas. $A$ rápida disseminação de conselhos de políticas públicas e de direitos pelos municípios do país, desde a década de 1990, está relacionada à indução para o estabelecimento dos fóruns promovida por meio da transferência de recursos financeiros federais para os níveis subnacionais de governo, condicionada, entre outros requisitos, à constituição desses organismos (PIRES, 2011, p. 142).

No entanto, esse modelo de gestão deu certo no papel e no início de suas atividades, onde de acordo com a legislação deve seguir as diretrizes da deliberação, participação e controle social das partes que compõe este equipamento, discutindo e chegando a um consenso sobre as melhores formas de solucionar as questões e dar respostas às necessidades coletivas. Com base nos fatos declarados, cabe ressaltar que se não houver consciência crítica acerca dos processos em construção, essa participação pode servir de instrumentos de manipulação de interesses coletivos em benefício de interesses privados (MACHADO, 2012, p. 129).

Nesse sentido, a autora ainda pontua que o ato de exercer o controle social deve ser compreendido em sua concepção geral e que a sociedade civil tem que ser capacitada para à tomada de decisão, para então ter maior possibilidade de inferência na destinação dos recursos e na fiscalização das ações do Estado e, que seu exercício tenha suporte na viabilidade das informações necessárias. Assim, foi apresentado pela entrevistada do segmento dos usuários que:

[...] em outro momento, adotei a estratégia de organizar um número de gestantes usuárias do serviço de Pré-natal, que estivessem interessadas em demonstrar ao poder público a necessidade em realizar reforma e ampliação do número de leitos credenciados no SUS [...] (Assistente Social - conselheiro do segmento dos usuários - entrevista em 03/11/2017).

Os conselhos municipais de saúde são também chamados de conselhos participativos. E, é através deles que a sociedade civil por intermédio de um aparelho deliberativo e decisório, alcança certa igualdade diante do Estado na gestão das políticas públicas numa esfera dita paritária. Apresentar novas demandas, discutir sobre orçamento e implementação nas políticas públicas, para que as mesmas supram suas necessidades sociais, mesmo frente as dificuldades ainda são argumentos que impulsionam a sociedade estar presente nos CMS's.

Quando estive participando desse Conselho em outro momento, adotei a estratégia [...], de compor um número expressivo de usuárias em favor da proposta que estava defendendo naquele momento. No entanto, na atual posição em que me encontro dentro do Conselho de Saúde, não consigo nem mesmo expor minha opinião quanto mais adotar qualquer tipo de estratégia para ampliação da participação dos usuários da política de saúde (Assistente Social - conselheiro do segmento dos usuários - entrevista em 03/11/2017).

O exercício ativo da atividade de um conselheiro tem suma relevância, tanto para promover a participação social quanto assegurar o direito do controle social da classe do segmento que representa dentro do CMS. Tal sujeito tem que fazer jus ao grupo que representa, considerando que sua atuação dentro do Conselho é contribuir para o bom andamento da política pública ao qual está referenciado. Para firmar o direito participativo no CMS de Campos dos Goytacazes, os conselheiros/representantes devem ter em mente que suas ações influenciam diretamente para os avanços e mudanças na política de saúde local, e, com isso o que tem que estar em primeiro lugar nos interesses tratados nesse espaço são os desejos e anseios da população usuária da política em questão. Assim, para uma Conselheira entrevistada

Estimular a participação popular foi [...] o posicionamento no período que fazia parte dos representantes do HPC. [Buscou] colocar para as usuárias dos serviços a importância da participação dessas, já que se tratava de questões que demandavam a garantia do aumento ou não dos serviços para esse público (Assistente Social - conselheiro do segmento dos usuários - entrevista em 03/11/2017). 
Os conselheiros do CMS, enquanto representantes de uma parcela da população campista, tem não somente que dar conta da responsabilidade social assumida, como também travar discussões nesse âmbito de deliberação intencionando a proporcionar mudanças e avanços significativos para a área da saúde.

Apesar dos grandes avanços referentes ao direito participativo na gestão da política de saúde, tendo a criação do SUS como expressão do ponto alto das conquistas dos usuários da saúde, ainda é necessário lutar para fortalecê-lo diariamente, e destacamos o papel fundamental do Serviço Social para potencializar a participação social.

Nesse aspecto, é possível verificar sua materialização no desempenho das atividades e/ou intervenções nos Conselhos Municipais através das seguintes indicações:

$\checkmark \quad$ A presença dos assistentes sociais nos espaços dos Conselhos configura-se como uma estratégia para a mobilização social;

$\checkmark \quad$ O Serviço Social nos Conselhos contribui para a elevação do grau de politização da sociedade civil, orientando para o controle social articulado com as bases representadas. Onde, fomentar a capacitação política continuada para conselheiros da sociedade civil parte de uma perspectiva crítica e propositiva da profissão;

$\checkmark \quad$ Buscar a utilização e divulgação dos meios de comunicação como mecanismos de controle social; socialização das deliberações dos Conselhos para outras Instituições/Entidades que não fazem parte do Conselho e, orientar a articulação com o Ministério Público, entre outras ações. Assim, apesar dos desafios para o exercício da participação e do controle social na atualidade, consideramos ser a participação da sociedade civil em espaços como o CMS, entre outras esferas de controle social, o melhor instrumento para favorecer a transformação tão urgente e necessária na política de saúde, não somente no município de Campos dos Goytacazes, mas em todos os municípios do país. A sociedade tendo consciência do impacto de sua ação propositiva no CMS, das possibilidades de mudanças que essa atitude pode proporcionar na política de saúde, será peça fundamental para as transformações na qualidade dos serviços ofertados na saúde em nosso município.

\section{REFERÊNCIAS}

[1] Barroco, Maria Lúcia S. Ética: fundamentos sócio-historicos. Biblioteca Básica do Serviço Social. v. 4, 3.ed. São Paulo: Cortez, 2010.

[2] Brasil. Conselho Nacional de Secretários de Saúde. As Conferências Nacionais de Saúde: Evolução e perspectivas./ Conselho Nacional de Secretários de Saúde. - Brasília: Conass, 2009.

[3] _ Constituição da República Federativa do Brasil (1988). Constituição Federal de 1988. Atualizada e Ampliada. 48. ed. - São Paulo: Saraiva, 2013a.

[4] _ Ministério da Saúde. Conselhos de saúde: a responsabilidade do controle social democrático do SUS / Ministério da Saúde, Conselho Nacional de Saúde. - 2. ed. - Brasília: Ministério da Saúde, 2013b.

[5] __ Lei no 8.080 de 19 de Setembro de 1990. Sistema Único de Saúde (SUS). Brasília, 1990. Disponível em: <http://www.planalto.gov.br/ccivil_03/leis/L8080.htm> Acesso em: 10 mai. 2017.

[6] L L L L L Sistema Único de Saúde - SUS e sobre as transferências intergovernamentais de recursos financeiros na área da saúde e dá outras providências. Brasília: CNS/Ministério da Saúde, 1990.

[7] — Ministério da Saúde. Coletânea de Normas para o Controle Social no Sistema Único de Saúde / Ministério da Saúde, Conselho Nacional de Saúde. Série E. Legislação de Saúde - 2. ed. Brasília : Editora do Ministério da Saúde, 2006.

[8] ___ Ministério da Saúde. Incentivo à Participação Popular e Controle Social no SUS: Textos técnicos para conselheiros de saúde. Brasília: IEC, 1994.

[9] Ministério da Saúde. Para entender o controle social na saúde/ Ministério da Saúde, Conselho Nacional de Saúde. - Brasília: Ministério da Saúde, 2014a. 
[10] Decreto no 8.243, de 23 de maio de 2014. Institui a Política Nacional de Participação Social - PNPS e o Sistema Nacional de Participação Social - SNPS, e dá outras providências. Brasília, 2014b. 73 Código de Ética do/a Assistente Social. Lei 8.662/93 de regulamentação da profissão. - 10ä. ed. rev. e atual. - Brasília: Conselho Federal de Serviço Social, CFESS, 2012a.

[11]

Resolução no 453 de 10 de Maio de 2012. Aprova diretrizes para instituição, reformulação, reestruturação e funcionamento dos Conselhos de Saúde. Conselho Nacional de Saúde - CNS: Brasília, 2012b.

[12] Bravo, Maria Inês Souza. Serviço Social e Reforma Sanitária - lutas sociais e práticas profissionais - 4. ed. São Paulo: Cortez, 2011.

[13] _ Maria Inês Souza. 0 trabalho do assistente social nas instâncias públicas de controle democrático no Brasil. Síntese do artigo publicado na coletânea -Serviço Social: direitos sociais e competências profissionais\|, Brasília: CFESS/ABEPSS, 2009.

[14] Cfess, Conselho Federal de Serviço Social. Atribuições Privativas do/a Assistente Social em Questão. 1a Edição Ampliada - reedição do texto de Marilda Iamamoto sobre as atribuições privativas do/a assistente social. 40ํㅡㄴ Encontro Nacional CFESS-CRESS: Brasília, 2012.

[15] Cns, Conferência Nacional de Saúde. Anais 8a Conferência Nacional de Saúde. - Centro de Documentação do Ministério da Saúde: Brasília, 1986.

[16] Cgu, Controladoria-Geral da União. Controle Social - Orientações aos cidadãos para participação na gestão pública e exercício do controle social. 3. ed. Coleção Olho Vivo - Brasília, DF: Secretária de Prevenção da Corrupção e Informações Estratégicas, 2012

[17] Conasems, Conselho Nacional de Secretarias Municipais de Saúde. Participação Social No SUS: O olhar da gestão municipal. XXX Congresso Nacional de Secretarias Municipais de Saúde. In: Revista Conasems, 2007.

[18] Correia, Maria Valéria Costa. Controle Social. In: Dicionário da Educação Profissional em Saúde. (Org.) Escola Politécnica de Saúde Joaquim Venâncio - Rio de janeiro: FIOCRUZ, Fundação Oswaldo Cruz, 2008.

[19] Gohn, Maria da Glória. Conselhos Gestores e a Participação sociopolítica. Coleção questões da nossa época; v. 84, 2. ed.- São Paulo: Cortez, 2003.

[20] _ Maria da Glória. Conselhos gestores na política social urbana e participação popular. Cadernos Metrópole - desigualdades e governança (Org.) n. 7, Pronex. Apoio CNPq/EDUC: 2002.

[21] Gohn, Maria da Glória. Conselhos gestores e gestão pública. In: Ciências Sociais Unisinos - v. 42, n. 1 São Leopoldo/ RS, 2006.

[22] Iegm, Índice de Efetividade da Gestão Municipal. Os Municípios do Estado do Rio de Janeiro. (Org.) Instituto Rui Barbosa - Apoio Tecnológico/DTI, 2015.

[23] Iamamoto, Marilda Villela. O Serviço Social na Contemporaneidade: trabalho e formação profissional. 21. ed. - São Paulo: Cortez, 2011.

[24] Lira, Rodrigo Anido. Representações, Participação e Cooptação nos Conselhos Municipais em Campos dos Goytacazes. Tese de Pós-graduação em Sociologia Política Uenf: Campos dos Goytacazes, 2012.

[25] Machado, Loiva Mara de Oliveira. Controle Social da Política de Assistência Social - Caminhos e Descaminhos. Porto Alegre: Edpucrs, 2012

[26] Nosswitz, Juliana. A Ação Profissional do Assistente Social nos Conselhos Municipais de Políticas Públicas uma análise a região da AMPLASC. Dissertação a título de Mestre em Serviço Social - PPGSS/UFSC: Florianópolis/SC, 2008.

[27] Pires, Roberto Rocha C. (Org.). Efetividade das instituições participativas no Brasil: estratégias de avaliação. v. 7 - (Diálogos para o desenvolvimento), Brasília: Ipea, 2011.

[28] Salvador, Evilasio. O controle democrático no financiamento e gestão do orçamento da Seguridade Social no Brasil. Textos \& Contextos, v. 11, n. 1 - Porto Alegre, 2012.

[29] Stotz, Eduardo Navarro. Participação Social. In: Dicionário da Educação Profissional em Saúde. (Org.) Escola Politécnica de Saúde Joaquim Venâncio - Rio de janeiro: Fundação Oswaldo Cruz - Fiocruz, 2008.

[30] Raichelis, Raquel. Democratizar a Gestão das Políticas Sociais - Um Desafio a Ser Enfrentado pela Sociedade Civil. In: Serviço Social e Saúde: Formação e Trabalho Profissional. Módulo 03. Capacitação em Serviço Social e Política Social. Programa de Capacitação Continuada para Assistentes Sociais. Brasília, CFESS, ABEPSS, Cead/Ned-Unb, 2000.

[31] _ _ Raquel. O Controle Social Democrático na Gestão e Orçamento Público 20 Anos Depois. In: Seminário Nacional - 0 Controle Social e a Consolidação do Estado Democrático de Direito - Brasília: Conselho Federal de Serviço Social - CFESS (Org.), 2011. 


\section{Capítulo 7}

\section{Políticas sociais em pequenos Municípios: Fundo público como diferencial no desenvolvimento}

\section{Edemar Rotta}

Ivann Carlos Lago

\section{Caroline Hentges}

Resumo: 0 artigo analisa a aplicação do fundo público em políticas sociais em pequenos municípios do Noroeste do Rio Grande do Sul, no período compreendido entre 1997 e 2015, visando estabelecer possíveis correlações com a dinâmica de desenvolvimento dos mesmos. Guia-se pelas premissas do método materialista histórico dialético no trabalho com os dados das contas municipais, disponíveis no site da Secretaria do Tesouro Nacional (STN). Demonstra-se e compara-se os dados, visando identificar possíveis correlações com os indicadores do Índice de Desenvolvimento Humano Municipal (IDHM). Constata-se tendência de crescimento dos valores totais; ampliação dos percentuais em 88,6\% dos municípios; repercussões diretas nos indicadores de desenvolvimento, com destaque para longevidade e educação.

Palavras-chave: Fundo público; políticas sociais; pequenos municípios; desenvolvimento. 


\section{INTRODUÇÃO}

O Brasil possui 5.570 municípios, dos quais $68,4 \%$ apresentam população até 20 mil habitantes, sendo considerados de pequeno porte e concentrando 15,8\% (32,3 milhões de habitantes) da população do país. Por outro lado, os municípios com mais de 500 mil habitantes são apenas 0,736\% (41 ao todo) e concentram 29,9\% da população do país (61,6 milhões de habitantes) (IBGE, 2017).

A Constituição brasileira de 1988 elevou os municípios à condição de "entes federativos, dotados de autonomia própria, materializada por sua capacidade de auto-organização, autogoverno, autoadministração e autolegislação" (LENZA, 2013, p. 473). Com isso eles passaram a desempenhar papel decisivo na concepção, organização e gestão das políticas públicas. Pode-se dizer que essa assertiva tornase ainda mais importante para o caso das políticas sociais, nas quais o processo de descentralização e controle social acabou por delegar aos municípios papel determinante no perfil das mesmas. Porém, os "modelos" de organização dessas mesmas políticas, no caso brasileiro, seguem padrões que se aplicam a municípios de médio e grande porte, de forma especial aqueles com população acima de 50 mil habitantes, que representam apenas 11,45\% (638) dos mesmos (CNM, 2015; IBGE, 2017).

Trata-se de uma realidade contraditória, pois ao mesmo tempo em que delega-se aos municípios papel determinante na gestão das políticas públicas, se exige e se aplica a eles padrões nos quais grande parte dos mesmos não consegue se enquadrar. Neste cenário, o estudo da situação vivenciada pelos pequenos municípios ${ }^{12}$, em termos de organização das políticas públicas, pode representar contribuição importante para entender a realidade e apresentar contribuições que possam qualificar os processos e as práticas. Nesta direção é que apresenta-se este artigo, como um dos resultados decorrentes de projeto ${ }^{13}$ de pesquisa em andamento, junto ao Programa de Mestrado em Desenvolvimento e Políticas Públicas, da Universidade Federal da Fronteira Sul (UFFS), que visa analisar a aplicação do fundo público em políticas sociais no âmbito dos municípios do Noroeste do Rio Grande do Sul.

Nos pequenos municípios as políticas públicas e, nestas, de forma especial, as sociais, tendem a adquirir papel determinante nas dinâmicas de desenvolvimento, na medida em que mobilizam grande parte do fundo público disponível; representam os principais espaços de disputa política entre os atores locais; qualificam as pessoas; garantem direitos; ampliam as oportunidades e contribuem para a melhoria das condições de vida da população local (ROTTA, LAGO e ROSSINI, 2017).

Os estudos a respeito da relação entre políticas sociais e dinâmicas de desenvolvimento ampliam-se, de forma significativa, a partir das últimas décadas do século XX. Em grande parte, essa ascensão como área de estudo, em diversas disciplinas, dá-se pelo fato do questionamento dos indicadores tradicionalmente utilizados para aferir o desenvolvimento de um país ou de uma região, especialmente o Produto Interno Bruto (PIB), e a emergência de novos indicadores, muitos deles ligados às áreas sociais. Com isso as políticas sociais passam a constituir, junto com o crescimento econômico, espaço privilegiado de atenção dos pesquisadores e dos agentes sociais e políticos que buscam entender e dinamizar processos de desenvolvimento (ROTTA, 2007).

Este texto insere-se neste propósito de compreender a relação entre políticas sociais e dinâmicas de desenvolvimento, com foco voltado para a realidade específica de um conjunto de pequenos municípios da região Noroeste do estado do Rio Grande do Sul. Organiza-se o mesmo em três partes essenciais. Na primeira, apresentam-se os pressupostos teóricos que orientam a pesquisa em curso e que é referência deste texto, com destaque para os conceitos analíticos de referência. Na segunda, apresenta-se a proposta metodológica utilizada na busca dos dados e na análise dos mesmos. Na terceira, demonstra-se os dados evidenciados e as análises realizadas a respeito da relação entre a aplicação do fundo público nas políticas sociais selecionadas e a dinâmica de desenvolvimento dos municípios.

\footnotetext{
12 Para efeitos deste texto compreende-se como pequenos municípios aqueles que apresentam população até 20 mil habitantes. Trata-se de compreensão corrente nos meios políticos (CNM, 2015) e amplamente utilizada para efeitos de estatísticas oficiais e do estabelecimento de políticas públicas (IBGE, 2017).

13 Projeto que vem sendo desenvolvido desde 2014 e que contou, em sua primeira fase (investigação dos municípios polo), com financiamento da Fundação de Amparo à Pesquisa do Estado do Rio Grande do Sul - FAPERGS. A segunda fase, na qual se estende a pesquisa para os demais municípios da região (77 ao todo), conta com apoio institucional da UFFS.
} 


\section{CONCEITOS ANALÍTICOS DE REFERÊNCIA}

A pesquisa em curso a respeito da aplicação do fundo público em políticas sociais nos pequenos municípios do Noroeste do Rio Grande do Sul, e que serve de referência para a elaboração deste texto, trabalha com três conceitos fundamentais: políticas sociais, fundo público e desenvolvimento. Tem-se presente que já são conceitos com tradição reflexiva consolidada na área das ciências humanas e sociais aplicadas, por isso não se pretende uma abordagem recorrente, mas sim deixar explícito o enfoque dado aos mesmos nesta pesquisa. Enfoque este também manifesto em publicações decorrentes desta pesquisa, com especial destaque para Rotta, Lago e Rossini (2017). Portanto, aqui, recobra-se algumas reflexões sobre estes conceitos.

Para o serviço social, o estudo das políticas sociais possui relação intrínseca com o seu objeto central: a questão social. A emergência da questão social, no contexto da sociedade capitalista e das relações tensas e contraditórias entre capital e trabalho, nas primeiras décadas do século XIX, na Europa Ocidental, fez com que fossem criadas diferentes estratégias para seu enfrentamento e que, muitas dessas, tivessem em sua base a concepção e implantação de políticas sociais. Esta relação umbilical entre questão social e políticas sociais fez do serviço social um espaço por excelência de estudo das políticas sociais, gerando tradições teóricas diferenciadas que evidenciam as múltiplas faces do tema e como ele se apresenta em contextos específicos (FALEIROS, 2000; BEHRING e BOSCHETTI, 2006; SILVA, 2014).

Analisando experiências concretas de implantação e posições teóricas presentes nos debates sobre políticas sociais, entre profissionais de diferentes áreas do conhecimento, Castro (2012) demonstra a inexistência de um conceito inequívoco ou consensual a respeito do que seja política social. Ciente dessa multiplicidade de definições, ele aponta para um campo multidisciplinar e com foco central nas ações do Estado, na perspectiva de garantir direitos aos cidadãos. Propõe que se entenda as políticas sociais como o "conjunto de programas e ações do Estado que se concretizam na garantia da oferta de bens e serviços, nas transferências de renda e regulação dos elementos do mercado" (p. 1014), com vistas a realizar a proteção e a promoção social. Retomando uma tradição que remonta aos clássicos da área do Serviço Social brasileiro ${ }^{14}$, Pfeifer (2014) relembra que as políticas sociais devem ser pensadas na perspectiva de responder "ao conjunto de necessidades sociais humanas" (p. 748), que são construídas e reconstruídas de acordo com o grau de desenvolvimento das sociedades (ROTTA, LAGO e ROSSINI, 2017).

Na tradição da produção teórica do serviço social é hegemônica a compreensão que situa as políticas sociais no conjunto das relações macroeconômicas do processo de produção e reprodução do capital e do contexto específico no qual o mesmo se realiza. Ou seja, elas devem ser situadas no contexto mais amplo de discussão a respeito dos projetos de sociedade em disputa; das relações entre capital e trabalho; dos conflitos de classe; das concepções de Estado e das próprias políticas públicas em seu conjunto. Neste processo elas são perpassadas por conflitos de classe e desempenham, de forma especial, três "funções": econômica, política e ideológica. Econômica, ao atuar no processo de barateamento da força de trabalho por meio da socialização dos custos de produção. Política, no sentido de garantir ao Estado, e, por consequência, ao grupo hegemônico que o controla, o controle de sua concepção e dos mecanismos básicos de sua operacionalização. Ideológica, ao funcionar como mecanismo de legitimação da ordem social vigente (NETTO, 1992; PASTORINI, 1997; FALEIROS, 2000; BEHRING e BOSCHETTI, 2006; SILVA, 2014).

Em relação à compreensão de fundo público, trabalha-se com a definição dada por Salvador (2012), ao entendê-lo como sendo "toda a capacidade de mobilização de recursos que o Estado tem para intervir na economia" (p. 07) e nas demais dimensões de organização da sociedade, quer via empresas públicas, política monetária, fiscal e tributária ou orçamento público, visando ao desempenho de suas múltiplas funções. Trata-se de parte do trabalho excedente que é apropriado pelo Estado, a fim de que o mesmo desempenhe as atribuições que a correlação de forças sociais define como de responsabilidade do Estado (ROTTA, LAGO e ROSSINI, 2017).

Na mesma dimensão do que ocorre com as políticas sociais, o fundo público desempenha papel relevante no processo de produção e reprodução do capital e da força de trabalho. Também está perpassado por relações de classe e pelas amplas disputas que se estabelecem na sociedade pela sua definição, sua operacionalização e seu controle. No caso brasileiro, Salvador (2012) destaca que o fundo público tem desempenhado, historicamente, muito mais uma função de transferir recursos do Estado para o processo

14 Tradição presente, de forma especial, na área do Serviço Social, a partir dos estudos de José Paulo Netto, Marilda Iamamoto, Potyara Pereira, Vicente de Paula Faleiros, Evaldo Vieira. Aldaíza Sposati, Elaine R. Behring, entre outros. 
de reprodução do capital, do que funcionar como mecanismo de redução das desigualdades e de garantia de direitos (ROTTA, LAGO e ROSSINI, 2017).

No que concerne à compreensão de desenvolvimento, a pesquisa filia-se ao enfoque histórico-estrutural, da tradição brasileira e latino-americana sistematizada nos escritos de Celso Furtado e Raúl Prebisch. Nesta tradição, a ideia de desenvolvimento possui ao menos três dimensões.

A primeira refere-se ao incremento da eficácia do sistema social de produção, na medida em que o mesmo, mediante a acumulação e o progresso técnico, eleva a produtividade de sua força de trabalho. A segunda relaciona-se à satisfação das necessidades humanas elementares da população no sentido de garantir a dignidade e promover a cidadania. A terceira diz respeito ao projeto ideológico de futuro, à consecução dos objetivos definidos na esfera política e de interesses de grupos e classes sociais. Por isso Furtado reitera que só haverá verdadeiro desenvolvimento onde existir um projeto social subjacente (ROTTA, LAGO e ROSSINI, 2017, p. 449).

Desenvolvimento implica, portanto, em um processo de transformação da estrutura produtiva, das relações sociais, das instituições, da organização política, das bases culturais e da própria relação dos seres humanos com a natureza. Trata-se de um fenômeno que acontece na dinâmica das relações sociais e em contextos concretos, conjugando crescimento econômico e melhoria das condições de vida da população como um todo. É objeto do jogo de forças, dos conflitos de classes, dos interesses dos diferentes grupos, das políticas públicas, dos governos e dos organismos nacionais e internacionais. É produto das relações tensas e contraditórias que se estabelecem no interior das sociedades e na relação destas com as demais (ROTTA, LAGO e ROSSINI, 2017).

As reflexões sobre sustentabilidade (SACHS, 2004) tem destacado que só há verdadeiro desenvolvimento quando o mesmo for pensado de forma a garantir condições de vida digna ${ }^{15}$ para todos, nesta e nas futuras gerações. Neste sentido são incluídas as dimensões econômica, política, cultural, social e ambiental. Faz-se necessário reduzir as desigualdades sociais e regionais, garantir a participação de todos, aperfeiçoar a democracia, respeitar as diversidades culturais e ideológicas, garantir as liberdades individuais e coletivas, preservar os ambientes naturais, buscar formas de convivência sustentável com a natureza, entre outros.

\section{METODOLOGIA UTILIZADA NA PESQUISA}

No desenvolvimento da pesquisa que é base para a elaboração deste texto trabalha-se com o método materialista histórico dialético, em suas categorias fundamentais da historicidade, da contradição e da totalidade. A historicidade no sentido da processualidade, da não naturalização dos fenômenos, da contextualização, do entendimento das suas vinculações objetivas com o real concreto vivido e com os espaços específicos. A contradição como possibilidade de perceber os diversos interesses em disputa, a não linearidade, os avanços, retrocessos e tensões que permeiam qualquer realidade concreta e suas manifestações. A totalidade como imperativo que permite perceber a interligação entre os diferentes elementos que compõem qualquer fenômeno, realidade ou manifestação do mesmo.

0 procedimento metodológico de referência é a análise de conteúdo como ferramenta auxiliar do método dialético. Bardin (1979) destaca três etapas a serem seguidas no processo de uso da análise de conteúdo: $a$ pré-análise, que é a fase de organização do material; a descrição analítica, onde o material organizado é submetido a um estudo aprofundado com base nos referenciais teóricos da pesquisa; e a interpretação referencial, onde os elementos da pesquisa são relacionados com as variáveis mais complexas da mesma e com a totalidade social em que estão inseridos.

Definiu-se como lócus da pesquisa o Noroeste do estado do Rio Grande do Sul, caracterizado por quatro microrregiões de COREDES, aglutinadas como "Região Funcional 07" a partir da estratégia de Planejamento da Secretaria de Planejamento, Gestão e Participação Cidadã (SEPLAN) ${ }^{16}$. 0 período definido para a pesquisa (1997-2015) dá-se em razão da disponibilidade dos dados junto à Secretaria do Tesouro

15 Entendendo vida digna como a garantia de das condições básicas para que o indivíduo possa viver e participar da sociedade de forma livre e cidadã.

16 Os Conselhos Regionais de Desenvolvimento do RS (COREDES) foram agregados em nove Regiões Funcionais de Planejamento, com base em critérios de homogeneidade econômica, ambiental e social e outras características similares (RIO GRANDE DO SUL, 2015). 
Nacional em formato semelhante que permite a organização e a comparação a partir da "planilha gasto por função", contendo os dados contábeis consolidados dos municípios referenciados. Esta opção foi realizada após pesquisas em outras fontes disponíveis ${ }^{17}$ e diálogo com os profissionais responsáveis pelo setor de contabilidade dos municípios que apontaram ser esta a melhor opção para a comparação proposta na pesquisa.

As planilhas de "gasto por função", dos 77 municípios integrantes da região selecionada, no período proposto, foram extraídas do sistema da Secretaria do Tesouro Nacional ${ }^{18} \mathrm{e}$ os dados organizados a partir das áreas de políticas sociais definidas ${ }^{19}$. Depois de organizados, os dados foram atualizados para a data de 31 de outubro de 2016, com base no Índice Nacional de Preços ao Consumidor Amplo (IPCA/IBGE), a fim de possibilitar comparações e análises. Neste artigo foca-se na análise dos dados relativos aos municípios com menos de 20 mil habitantes, tendo como referência o censo de 2010, que representam $90,90 \%$ (70 municípios) do total da Região Funcional 07.

Para o estabelecimento de interfaces entre os recursos do fundo público aplicados em políticas sociais, dinâmica econômica regional e melhoria da qualidade de vida da população utiliza-se como referência ${ }^{20} \mathrm{o}$ Índice de Desenvolvimento Humano Municipal (IDHM), entendendo que o mesmo é capaz de traduzir os aspectos básicos do desenvolvimento que estão associados à área de política social selecionada.

0 estudo concentra-se na análise dos valores totais do fundo público municipal, representados pelo orçamento anual, aplicados nas políticas sociais selecionadas e nos percentuais relacionados ao total disponível no orçamento de cada ano. Para a possível repercussão nos indicadores de desenvolvimento toma-se como referência os indicadores do IDHM nos anos base dos censos demográficos de 1991, 2000 e 2000. Entende-se que a referência a 1991 é importante por retratar uma realidade anterior ao período inicial do levantamento de dados efetuados pela pesquisa. Assim como 2010 já representa o primeiro parâmetro, mesmo que parcial. Porém, 2010 é, sem dúvida, a referência de maior importância para o estudo, pois ela é capaz de captar as repercussões mais expressivas dos recursos aplicados.

\section{ANÁLISE DOS DADOS}

Como ponto de partida toma-se como referência o total dos recursos do fundo público disponível nos orçamentos anuais dos municípios, para o período analisado, que foram aplicados no conjunto das políticas sociais selecionadas. Os dados foram atualizados para 31 de outubro de 2016, com base no IPCA/IBGE, a fim de configurar valores comparáveis e passíveis de identificação de tendências.

Percebe-se que os valores totais aplicados em políticas sociais apresentam tendência de crescimento ao longo do período, com leves oscilações, de um ano para outro, em alguns casos, mas sem comprometer o aumento expressivo no período investigado, que ficou na média dos $800 \%$. Essa tendência de crescimento é expressiva quando comparados o início e o final do período, para todos os municípios, somente ficando

\footnotetext{
17 Nas câmaras municipais de vereadores, prefeituras e Tribunal de Contas do Estado do RS.

18 Entre os anos de 1997 a 2012 os dados das contas municipais eram disponibilizados pela Secretaria do Tesouro Nacional através da Finanças Brasil - Dados Contábeis do Municípios (FINBRA). A partir de 2013, o Tesouro Nacional implantou o Sistema de Informações Contábeis e Fiscais do Setor Público Brasileiro (SICONFI). Vide https://siconfi.tesouro.gov.br/siconfi/index.jsf

19 Trabalha-se com cinco áreas de políticas sociais: educação e cultura, saúde e saneamento, habitação e urbanismo, previdência e assistência, trabalho. Estes respectivos agrupamentos foram realizados tendo presente que os dados disponíveis junto ao Tesouro Nacional, entre 1997 e 2001, nas planilhas "gastos por função" agregavam estas mesmas áreas de política social, tornando impossível desagregar os dados das mesmas para a análise deste período. A partir de 2002 eles passaram a constar todos separados, nas planilhas gastos por função. A fim de preservar a proposta analítica e o período, optou-se, a partir de 2002, por somar as áreas e manter a agregação inicial, como área de política social integrada. Estas cinco áreas de política social foram escolhidas por representarem, durante do período, a quase totalidade dos recursos do fundo público aplicado em políticas sociais por parte dos municípios investigados.

20 Sabe-se da existência do IDESE, mas os dados, para a área, são praticamente os mesmos. O IDESE nasceu de uma parceria entre a Faculdade de Economia da UFRGS e a Fundação de Economia e Estatística do Estado do Rio Grande do Sul (FEE/RS) na perspectiva de produzir indicadores mais amplos do que os usados no IDHM. Em sua versão inicial, trabalhava com quatro blocos de indicadores, cada um representando $25 \%$ na composição de um indicador final de desenvolvimento: educação, saúde, saneamento básico e renda. A dificuldade em captar dados sobre indicadores de saneamento para todos os municípios do estado e em condições de comparação, fizeram com que a equipe técnica modificasse a proposta e incorporasse os indicadores de saneamento aos de saúde, aproximando-se do IDHM, no quesito longevidade. 0 diferencial do IDESE é que ele é apurado anualmente, enquanto o IDHM é apenas por ocasião dos Censos Demográficos. Nesta pesquisa, como tem-se um período anterior a 2006, optou-se pelo IDHM, pois os dados do IDESE para o período 1997 a 2006 não são comparáveis aos posteriores a 2006.
} 
Tópicos em Ciências Sociais - Volume 2

abaixo dos 500\% para os municípios que se emanciparam no ano 2000, passando a contar com orçamento próprio em 2001. Em 21 municípios a taxa de crescimento foi superior a $1.000 \%$ e em um desses chegou a $2.072 \%$. Confira no quadro ${ }^{21}$ abaixo.

Quadro 01: Trajetória dos montantes totais do fundo público aplicado em políticas sociais: 1997 a 2015 , representados em intervalos trienais.

\begin{tabular}{|c|c|c|c|c|c|c|c|}
\hline MUNTĆPIO & 1997 & 2000 & 2003 & 2006 & 2009 & 2012 & 2015 \\
\hline A URICARA & 1.697 .145 .88 & 2.281 .447 .43 & 3.198 .179 .73 & 5.537 .059 .36 & 6.999 .086 .48 & 10.895 .10494 & 12.204 .840 .09 \\
\hline ALBCRIM & 1.550 .05730 & $2.056 .440,94$ & 2.931 .123 .71 & 3.767 .796 .61 & $5.939 .732,79$ & 7916.138 .93 & 9.362 .563 .51 \\
\hline ALECRIA & 1232399.80 & 1915.897 .00 & 2.978 .718 .00 & 4.024 .732 .16 & 5.453 .030 .45 & 7.841 .88098 & 9.523 .706 .10 \\
\hline A UGGUSTO PESTANA & 1.353 .504 .63 & 2.448 .000 .22 & 3.243 .602 .73 & 4.77328491 & 6.268 .741 .07 & 10.524 .298 .59 & 13208.849 .41 \\
\hline BARRA DOGUARITA & 603283.32 & 997.830 .48 & 1.692912 .07 & 2.304 .084 .11 & 2.688 .528 .79 & 6.220 .054 .83 & 6.526 .011 .15 \\
\hline BOA USTA DO BURICA & 552.723 .72 & 1.890 .731 .00 & 2.028 .765 .79 & 4.393 .852 .76 & 5.842369 .04 & 9.397349 .72 & 11.498 .752 .75 \\
\hline BOM PROGRESSO & 602.936 .28 & 943.708 .10 & 1.590 .628 .56 & $2.478 .964,69$ & 4.087 .628 .37 & 5.069 .485 .26 & 5.901 .07959 \\
\hline BOSSOROCA & 1.604 .28 .51 & 2552.173 .10 & 3.509 .020 .15 & 5.52399030 & 6.759 .725 .70 & 11261.040 .73 & 8.532 .457 .42 \\
\hline BOZANO & $\mathrm{DNI}^{*}$ & $\mathrm{DNI}^{*}$ & 1.644 .585 .01 & 2.803 .505 .85 & 2.850 .838 .34 & 4.560559 .72 & 5.461 .212 .08 \\
\hline BRAGA & 1.093 .038 .43 & 1.198 .469 .26 & 1.675290 .00 & 2.437 .01338 & 3.544302 .25 & 6.116 .945 .38 & 5.069 .320 .10 \\
\hline CAIRATÉ & 986.782 .93 & 2.496 .850 .69 & 2.308 .544 .23 & 3.576 .676 .86 & 4.742 .452 .79 & 7555.10093 & 9251.492 .35 \\
\hline CAMPINA DAS MISSO̊ES & $933.790,71$ & 1.870 .329 .52 & $2.676 .756,03$ & 4.340 .898 .19 & 5.729 .603 .80 & $8.734243,64$ & 9.706 .130 .89 \\
\hline CAMPONOVO & 1.156 .01192 & 1925.156 .94 & 2.359 .121 .54 & 3.841 .950 .76 & 5308.71528 & 8.403 .383 .59 & 9.494 .22 .14 \\
\hline CÂNDIDO GODá & 1.022 .063 .61 & 1.875 .691 .07 & 2.604 .865 .61 & 4.317 .659 .73 & 5.11737429 & 7.861 .12494 & 10.296 .59757 \\
\hline CATUIPE & 1.530 .990 .42 & 3.222 .060 .00 & 3.991 .858 .00 & 5.486 .765 .00 & 7.01920651 & 12.076 .091 .65 & 15203.285 .85 \\
\hline CERROLARGO & 2.107 .851 .96 & 3.835367 .79 & 4.929 .669 .35 & 7.019 .061 .74 & 9.610945 .32 & 19.787 .21126 & 16.352 .143 .75 \\
\hline CHLAPETTA & 958.989 .84 & 1.636 .811 .20 & 2.683 .088 .24 & 4.484 .740 .25 & $5.012047,15$ & 8.707 .61294 & 8.789 .805 .35 \\
\hline CONDOR & 1.077 .82950 & 2.490 .697 .99 & 3.074 .908 .59 & 5.199 .884 .60 & 7212.183 .36 & 12556.884 .81 & 12.590 .761 .18 \\
\hline CORONEL BARROS & 836.766 .21 & 1272.139 .22 & 1.888976 .73 & 2.611 .04699 & 3.563 .054 .09 & 5.848 .029 .08 & 8.572 .415 .46 \\
\hline CORONEL BICACO & 1.715245 .12 & 2.432 .852 .00 & 3.565 .515 .00 & 5.210 .459 .19 & 7.482 .104 .55 & 9.515 .475 .70 & 11.243 .28898 \\
\hline CRISSTUMAL & 2.442 .556 .73 & 3.475 .110 .40 & 4.847226 .19 & 8.662 .79496 & 11.470 .166 .85 & 17.774 .26290 & 24.644 .753 .88 \\
\hline DERRURADAS & 766.759 .52 & 1.160 .676 .00 & 2.027 .518 .48 & 3.244 .500 .81 & 7.209921 .07 & 7.566378 .93 & 7.754 .011 .40 \\
\hline DEZESSES DENOVEMRRO & 707.826 .75 & 804.355 .05 & 1.447 .119 .00 & 2.092599 .00 & 3.459283 .00 & 5.406 .127 .00 & 5.816 .007 .65 \\
\hline DOUTORMAURICIO CARDOSO & 1226.012 .01 & 1.950 .853 .68 & 4.805 .890 .00 & 3.225 .712 .00 & 4.894 .804 .00 & 6.671956 .00 & 10.427 .793 .37 \\
\hline ENTRE-IUUIS & 1.842 .64728 & 3223.614 .00 & 2.449 .069 .00 & 5.014318 .85 & 6.975 .55492 & 13.858 .040 .47 & 15.513 .197 .62 \\
\hline ESPERANCA DO SUL & 812.554 .43 & 1.191 .435 .84 & 2.130 .798 .39 & 3.01759659 & 4.728 .168 .49 & 6.723 .601 .92 & 6.943 .137 .19 \\
\hline EUGANTO DE CASTRO & 731.507 .67 & 1.461 .449 .47 & 2.040 .099 .94 & 3.734 .779 .70 & 3.728 .833 .84 & 6.156 .788 .10 & 6.224 .58191 \\
\hline GARRUCHOS & 638.703 .22 & 1.436 .780 .00 & 2.444 .486 .69 & 3.608 .728 .14 & 5.197 .477 .07 & 11.113 .569 .55 & 6.561 .575 .10 \\
\hline GRUÁ & 3.564366 .24 & 6.145 .846 .74 & 9.110397 .55 & 11.188 .717 .82 & 20.443 .481 .23 & 28.642 .292 .25 & 35.426 .92332 \\
\hline GUARAN DASMISSOES & 1.391 .483 .51 & 2.877 .20 .00 & 3.351 .942 .05 & 5.048 .557 .00 & 6.010 .403 .19 & 12.093 .58495 & 13.630 .12334 \\
\hline HORIZONTINA & 4.996 .537 .98 & 8.006 .709 .92 & 9.285 .167 .24 & 14.893 .894 .64 & 18.544 .05 .19 & 28.569 .876 .63 & 38.920 .349 .33 \\
\hline HUMAITÁ & 1.080 .530 .75 & 1.732 .462 .7 & 2.706337 .31 & 3.883 .686 .44 & 6.06535205 & 8.874980 .06 & 9.747 .579 .04 \\
\hline INDEPENDÉNCIA & 1264.731 .77 & 2.871 .478 .52 & 3.011 .113 .17 & 4.337 .420 .68 & 6.573 .133 .13 & 8.280 .790 .83 & 10.766 .778 .08 \\
\hline INHACORÁ & 834.024 .87 & 1338.592 .00 & 2.179 .549 .49 & 3.040 .172 .78 & 4.50135999 & 6.579202 .84 & 5.556 .158 .52 \\
\hline JOIA & 1.796 .659 .86 & 3.113 .750 .52 & 4.034 .453 .04 & 4.63 .891 .33 & 8.028357 .74 & 15.431 .915 .43 & 16.567 .745 .71 \\
\hline MA TOQUEMAADO & $\mathrm{DNI}^{*}$ & $\mathrm{DNI}^{*}$ & 1.643 .348 .40 & 2.561 .797 .40 & 4.058 .585 .76 & 5.841 .726 .14 & 7.720 .221 .32 \\
\hline MIRAGUAI & 623.981 .55 & 1309204.34 & 2.153 .126 .32 & 3.278358 .66 & 4278.891 .59 & 7.434 .054 .20 & 8.501 .733 .62 \\
\hline NOVA CANDE_ÁRIA & 399.058 .59 & 1323.015 .96 & 1.667 .606 .50 & 3.000 .671 .28 & 3.603 .469 .07 & 4.983222550 & 7.105 .706 .87 \\
\hline NOVA RAMADA & 510.726 .02 & 1.198 .211 .33 & 2.063 .703 .27 & 3.047 .711 .13 & 4.066 .131 .37 & 6.216 .557 .81 & 5.55 .317 .81 \\
\hline NOVOMACHADO & 1.053 .053 .42 & 1369.505 .00 & 1.786 .413 .00 & 3.09735197 & 3.159 .814 .81 & 5339.600 .85 & 6.830 .858 .52 \\
\hline EEJUCARA & 1.077 .025 .80 & 2.229 .012 .24 & 2.79726271 & 4.433 .13527 & 5.522 .559 .43 & 9.994 .957 .87 & 10.987 .28754 \\
\hline PRAPO & 701272.40 & 1.120 .404 .39 & 1.816 .025 .34 & 3.069 .106 .15 & 4.089 .751 .33 & 5.585 .031 .01 & 7.091 .977 .61 \\
\hline PORTOLUCENA & 903.095 .99 & 1.507 .043 .12 & 2.079 .508 .48 & 3.128 .756 .04 & 4.416 .651 .09 & 6.658 .674 .56 & 8.003 .94622 \\
\hline PORTOMAUÁ & 683.817 .78 & 1242.734 .86 & 1.855 .620 .88 & 2.27 .622 .60 & 3.114547 .69 & 4.819 .87599 & 6.033 .063 .64 \\
\hline PORTO VERA CRUZ & 458.626 .83 & 1.013 .038 .69 & 1.799 .755 .00 & 2.256 .672 .31 & 2.777 .695 .15 & 3.088 .592 .60 & 5.000 .724 .68 \\
\hline PORTO XAVIER & 1.501 .077 .91 & 3233.490 .18 & 3.060 .854 .97 & 5.260 .808 .20 & 9.414 .414 .19 & 15.617 .760 .51 & 15.432 .755 .42 \\
\hline REDENTORA & 900.132 .50 & 2.170 .718 .81 & 3.722 .189 .52 & 5.22827538 & 7.162 .844 .74 & 10.866 .187 .40 & 13.068 .096 .17 \\
\hline ROLADOR & $\mathrm{DNI}^{*}$ & $\mathrm{DNI}^{*}$ & 1.62 .906 .59 & 2.555 .719 .93 & 3.043 .007 .11 & 4.381 .790036 & 5.678 .350 .43 \\
\hline ROQUB GONZALES & 1375,31752 & 2.187342 .86 & 2.586 .885 .55 & 3.882 .135 .00 & 6.602 .708 .19 & 11.572 .618 .75 & 12.364 .981 .09 \\
\hline SALVADORDASMISSOES & 896.083 .35 & 1.476 .482 .00 & 1.818 .650 .00 & 2.246316 .09 & 5269.408 .86 & 6.47633394 & 7.195 .232 .21 \\
\hline SANTO ANTONIO DA SMISSOES & 1.861 .597 .77 & 3309.733 .57 & 4.055 .124 .38 & 7.668 .96428 & 8.758 .656 .14 & 12.603 .321 .93 & 20.052 .071 .00 \\
\hline SANTO AUGUSTO & 3.187 .52 .45 & 5204.520 .69 & 6.003 .720 .77 & 7.986958 .36 & 11.991 .738 .17 & 16.092 .948 .68 & 2.547 .671 .83 \\
\hline SANTO CRISTO & 2.305 .635 .21 & 4273.052 .24 & 6.508 .202 .57 & 6.348 .390 .65 & 11.730 .908 .36 & 15.975 .59592 & 23.149 .69596 \\
\hline SA O JOSÉ DO INHACORÁ & 21.899 .22 & 1257.612 .00 & 1.619 .511 .07 & 2.744238 .10 & 3.062 .448 .88 & 4.459 .047 .77 & 5.842 .329 .34 \\
\hline SAOMARTINHO & 880.019 .43 & 1.819 .468 .81 & 2.400 .402 .70 & 3.771 .778 .55 & 6225.802 .48 & 10298.80130 & 9.908 .28 .66 \\
\hline SAOMIGUEL DASMISSCES & 1.884 .095 .63 & 2.709 .708 .77 & 3.732 .024 .08 & 6.010 .657 .59 & 8.593 .796 .14 & 12.343 .209 .49 & 14217.199 .37 \\
\hline SAONCOLAU & 1.527 .438 .31 & 2.247 .710 .19 & 3.097919 .42 & 4.072 .060 .82 & 5309.194 .59 & 9338.11055 & 10.095 .02272 \\
\hline SAOPAULODAS MISSOES & 1.454 .407 .86 & 2.493 .395 .00 & 3.554 .811 .64 & 4.839 .498 .99 & 6210.421 .77 & 10.513 .158 .05 & 12.970 .04658 \\
\hline SA O PEDRO DO BUTLÁ & 694.156 .01 & 1.461 .843 .85 & 1.851 .016 .13 & 3.330 .084 .98 & 4.11235754 & 6.100984 .55 & 6.727 .77 .41 \\
\hline SA O VALÉRO DO SUL & 978.653 .64 & 1.557 .426 .00 & 1.215 .136 .17 & 2.64750536 & 3522.114 .89 & 4978.332 .39 & 5.040 .227 .35 \\
\hline SEDE NOVA & 984.922 .77 & 1.688 .422 .42 & 1.649 .609 .18 & 2.197 .148 .98 & 3.482 .099 .98 & 7220.812 .83 & 6941.801 .26 \\
\hline SENADOR SALGADO FILO & 609.760 .35 & 1.527 .587 .27 & 2.110 .710 .59 & 3.33238359 & 3.01340 .22 & 6.57637731 & 7.810 .866 .81 \\
\hline SETEDE SETEMRRO & 417.718 .36 & 1.099 .680 .67 & 1.418 .104 .26 & 2.392 .788 .97 & 2.644 .432 .38 & 4.055589 .87 & 5.070 .334 .27 \\
\hline TENENTEPORTELA & 2.232 .010 .86 & 3.494283 .16 & 5.76 .422 .00 & 6.515 .444 .66 & 11.020 .401 .08 & 18.995 .791 .84 & 19.322 .038 .28 \\
\hline TIRADENTES DO SUL & 1295.891 .46 & 1.883 .007 .54 & 2.372 .565 .65 & 4.246 .793 .08 & 6.158 .084 .02 & 9900.618 .48 & 8.739 .534 .78 \\
\hline TUCUNDUVA & 1.196 .706 .17 & 2.056 .184 .64 & 2.842 .738 .22 & 3.972313 .67 & 4.614 .077 .00 & 6.003 .640 .13 & 9.791 .239 .58 \\
\hline TUPARENDI & 1.116366 .07 & 2.147255 .00 & 3.494 .180 .76 & 4.872 .435 .82 & 6.435 .421 .37 & 11.640 .135 .32 & 13.354 .19790 \\
\hline URIRETAMA & 644336.54 & 1.393 .614 .04 & 1.499385 .56 & 2.346 .791 .63 & 3215.06058 & 4.682 .129 .43 & 5227.378 .37 \\
\hline VISTA GAÚCHA & 734.475 .22 & 1.348 .556 .76 & 1.842 .668 .19 & 3.124510 .01 & 3.665 .059 .43 & 6.685 .727 .72 & 6.463 .999 .59 \\
\hline MTÓRIA DAS MISSOES & 70.739 .90 & $1.599 .619,00$ & 1.573 .441 .58 & 2.408 .302 .38 & 5.904 .847 .58 & 5.260 .580 .45 & 6.602 .77 .23 \\
\hline
\end{tabular}

* Dados não disponíveis - município emancipado em 2000.

Fonte: BRASIL (2013 e 2016). Dados organizados pelos autores.

21 Optou-se por representar a trajetória dos dados em intervalos trienais em decorrência da dimensão do quadro, da significância das alterações e da possibilidade de visualização dos mesmos. 
Evidencia-se que os acréscimos mais significativos nos valores do fundo público aplicados em políticas sociais ocorrem entre 2003 e 2013, período no qual o país apresentou crescimento mais expressivo da economia, com destaque para a agropecuária, a indústria associada à mesma e o setor de serviços. Setores estes que também são as bases da economia da região em estudo.

Outro aspecto que chama a atenção quando se olham os valores totais aplicados em políticas sociais é que eles não acompanham, necessariamente, o comportamento observado nos valores totais disponíveis no orçamento geral dos municípios, especialmente a partir da década de 2000. Isso pode representar uma tendência de maior disputa pelo fundo público disponível aos municípios. Uma análise detalhada dos percentuais do fundo público investidos em cada uma das políticas selecionadas e no seu conjunto, podem auxiliar a elucidar este fenômeno.

Analisando os percentuais aplicados percebe-se que eles aumentam, ao longo do período estudado, em 62 municípios; mantém-se estáveis em apenas três e diminuem em cinco. 0 aumento dos percentuais é bem mais expressivo do que as reduções, denotando uma tendência de valorização das políticas sociais e de sua correspondência na ampliação dos valores do fundo público a ser aplicado nas mesmas. Pode-se dizer que se sai de uma faixa média de $50 \%$ do fundo público aplicado em políticas sociais, em 1997, para uma faixa média acima de 60\%, em 2015. 0 que é um fato significativo quando se analisam os valores envolvidos.

Olhando os percentuais pode-se observar uma tendência de maior oscilação do que a observada na análise dos montantes totais. No caso dos montantes totais aplicados, percebe-se uma tendência mais uniforme de crescimento. Porém, ao se verificar os percentuais, evidencia-se que em nenhum dos 70 municípios analisados eles crescem de forma permanente ao longo do período. Isso evidencia que, mesmo existindo uma tendência de crescimento dos valores totais e dos percentuais aplicados ao longo do período analisado, existe uma oscilação que, em alguns casos, é bem expressiva, e necessita de estudos complementares para ser elucidada. Entre as hipóteses possíveis de serem levantadas como explicação para este fenômeno pode-se aventar a ligação com a tendência político-ideológica das respectivas gestões municipais ao longo do período; a intensificação da disputa pelo fundo público entre os diferentes atores sociais presentes no cenário; ou até mesmo o crescimento das receitas desvinculadas acima das que possuem vinculação legal de sua aplicação. Vide os dados percentuais no quadro 2.

Outra tendência, também já evidenciada em pesquisas anteriores (ROTTA; LAGO e ROSSINI, 2017), é que a definição legal de percentuais mínimos a serem aplicados em educação e em saúde gera maior estabilidade nestas áreas, porém pode estar relegando as demais a uma espécie de "repartição das sobras". Nos períodos em que há maiores receitas, estas outras áreas são contempladas com maiores recursos. Porém, em períodos de restrição, os cortes atingem primeiro estas outras áreas. Esta situação de instabilidade pode contribuir para agravar o quadro de dificuldades no estabelecimento de políticas públicas municipais de longo prazo para as mesmas.

Analisando as possíveis relações entre os investimentos realizados em políticas sociais e os indicadores de desenvolvimento é possível identificar ao menos três aspectos que mais chamam atenção. 0 primeiro deles refere-se aos indicadores de longevidade. Dos 70 municípios investigados, 67 encontram-se, em 2010, na condição de alto22 desenvolvimento (acima de 0,800) para esta área, enquanto, em 1991, apenas dois deles encontravam-se nesta condição. Tendo presente que este indicador tem uma relação direta com as condições de saúde e saneamento básico, pode-se inferir que a ampliação significativa (da faixa média de $10 \%$ para 25\%) dos investimentos nestas áreas, por parte dos municípios, teve correspondência com os resultados alcançados.

O segundo aspecto que se pode destacar refere-se aos indicadores ligados à área da educação. Trata-se da área que apresenta os piores indicadores na composição do IDHM ao longo das três séries (1991, 2000 e 2010) analisadas. Em 1991, os 70 municípios da região apresentavam indicadores de muito baixo desenvolvimento, sendo que 59 deles com índices abaixo de 0,300, denotando uma condição alarmante. Em 2010, apenas um município ainda encontrava-se na condição de muito baixo desenvolvimento, com índice de 0,480; 29 estavam na condição de baixo desenvolvimento; 37 na condição de médio; e 03 na condição de alto desenvolvimento. 0 quadro ainda é preocupante, mas a área da educação foi a que apresentou o maior percentual de crescimento nos indicadores que compõem o IDHM ao longo do período. Olhando para a relação com os valores do fundo público aplicado, percebe-se um crescimento expressivo nos valores per capita, porém, pouca variação em termos de percentuais (ficando na média dos $25 \%$ ) na relação com o total do fundo público disponível aos municípios.

$22 \mathrm{Na}$ classificação feita pela IDHM adotam-se 5 faixas de desenvolvimento: muito baixo $(0$ a 0,499$)$, baixo $(0,500$ a $0,599)$, médio $(0,600$ a 0,699$)$, alto $(0,700$ a 0,799$)$ e muito alto (acima de 0,800$)$. 
Quadro 02: Percentuais do fundo público municipal aplicados nas políticas sociais selecionadas: 1997 a 2015.

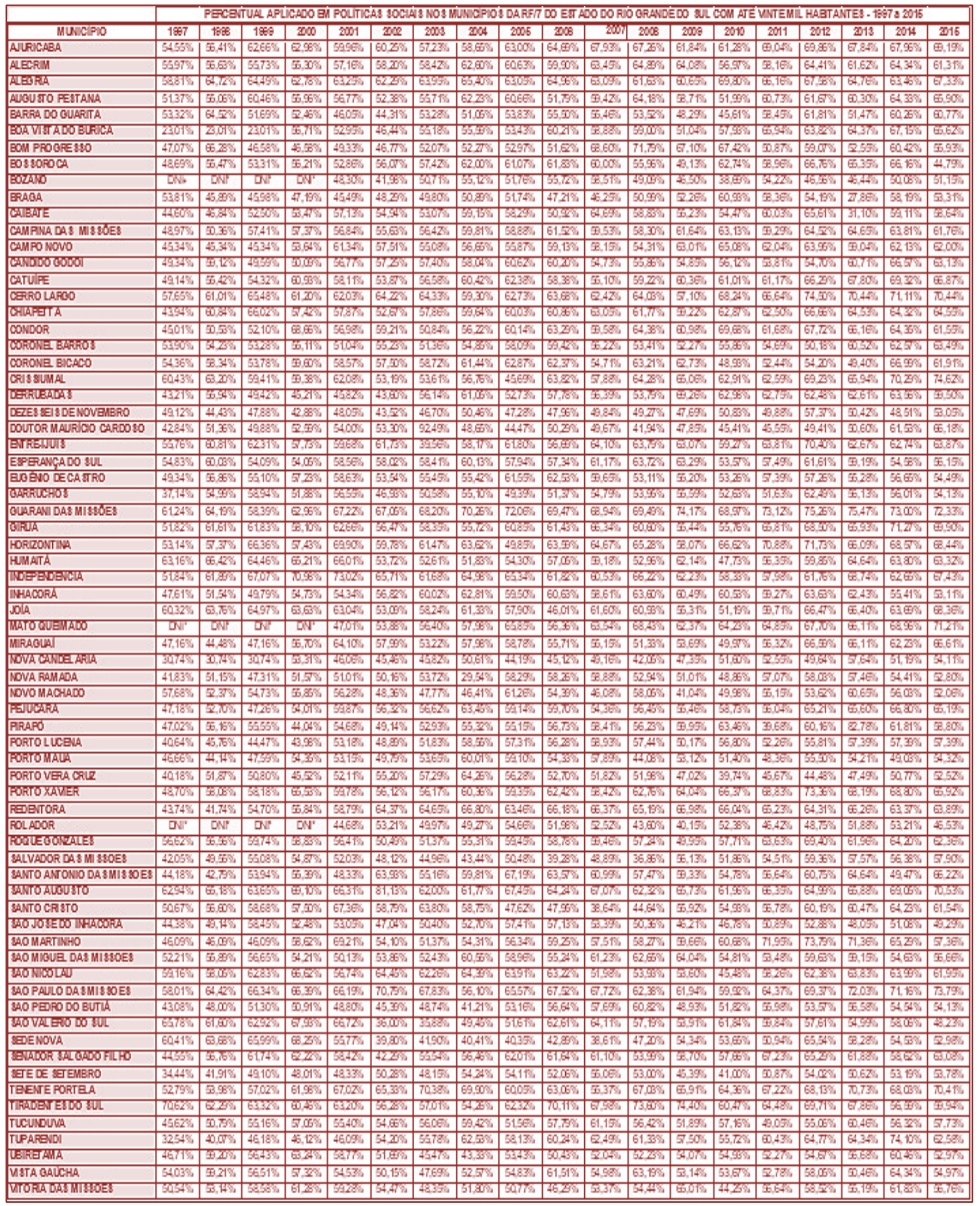

* Dados não disponíveis - município emancipado em 2000.

Fonte: BRASIL (2013 e 2016). Dados organizados pelos autores.

O terceiro aspecto que se pode destacar, em termos de relação entre investimentos do fundo público em políticas sociais e indicadores de desenvolvimento, é o fato de que, mesmo sendo a RF 07, uma das regiões do RS mais "deprimidas economicamente" ao longo do período analisado (RIO GRANDE DO SUL, 2015), os municípios da mesma apresentaram progressos significativos em termos de IDHM. Em 1991, 59 municípios encontravam-se na condição de muito baixo desenvolvimento e os outros 11, na condição de baixo desenvolvimento. Em 2010, 41 municípios alcançaram a condição de alto desenvolvimento e 29 a condição de médio desenvolvimento. 
Quadro 03: Índice de Desenvolvimento Humano Municipal: 1991, 2000 e 2010.

\begin{tabular}{|c|c|c|c|c|c|c|c|c|c|c|c|c|}
\hline \multirow{2}{*}{ MUNICIPIO } & \multicolumn{3}{|c|}{$\frac{\text { RENA }}{\text { RENA }}$} & \multicolumn{3}{|c|}{ LONGEVIDADE } & \multicolumn{3}{|c|}{ EDUCACIO } & \multicolumn{3}{|c|}{ IDHM } \\
\hline & 1991 & 2000 & 2010 & 1991 & 2000 & 2010 & 1991 & 2000 & 2010 & 1991 & 2000 & 2010 \\
\hline AJURICABAA & 0.593 & 0.653 & 0.769 & 0.720 & 0.804 & 0.850 & $0.2 \approx 9$ & 0.513 & 0,658 & 0,498 & 0.645 & 0.753 \\
\hline AIECRNM & 0.503 & 0.576 & 0,683 & 0.718 & 0.777 & 0,852 & 0,209 & 0,357 & 0.522 & 0.425 & 0.548 & 0.672 \\
\hline AIEGRIA & 0.525 & 0.582 & 0.717 & 0.720 & 0.786 & 0,818 & 0.185 & 0.423 & 0.572 & 0,412 & 0.578 & 0.655 \\
\hline AUGUSTO PEST ANA & 0.636 & 0.653 & 0.779 & 0.716 & 0.815 & 0.847 & 0.277 & 0.450 & 0,021 & 0.502 & 2.65 & 0,743 \\
\hline BARRA DOGUARIA & 0.498 & 0.677 & $0 \leq 5$ & 0.727 & 0.773 & 0.845 & 0.194 & 0.392 & 0.672 & 0.41 & 0.559 & 0.734 \\
\hline BOA VISTA DO BURICA & 0.566 & 0.681 & 0.761 & 0.750 & 0.802 & 0.834 & 0.360 & 0.548 & 0.097 & 0.535 & 0.669 & 0,702 \\
\hline BCAM PROGRESSO & 0.493 & 0.578 & 0.700 & 0.726 & 0.775 & 0.840 & 0.188 & 0.405 & 0.643 & 0.407 & 0.565 & 0.723 \\
\hline BOS SCROCA & 0.550 & 0.592 & 0.665 & 0,709 & 0.777 & 0,821 & 0.244 & 0,438 & 0,608 & 0.457 & 0.586 & 0,692 \\
\hline BOZANO & 0.547 & 0.672 & 0.773 & 0.720 & 0.811 & 0.853 & 0.227 & 0.427 & 0.028 & 0.447 & 0.615 & 0.745 \\
\hline BRAGA & 0.403 & 0.551 & Q.556 & 0,653 & 0.747 & 0.830 & 0.175 & 0,411 & 0.50 & 0.375 & 0.553 & 0.674 \\
\hline CAIBATÉ & 0.588 & 0.633 & 0.709 & 0.728 & 0.771 & 0.857 & 0.26 & 0.475 & 0.611 & 0.483 & 0.614 & 0.719 \\
\hline CAMPINA DAS MISSÕES & 0.524 & 0.591 & 0.08 & 0.706 & 0.781 & 0.849 & 0.36 & 0.484 & 0.677 & 0.515 & 0.607 & 0,738 \\
\hline CAMPO NOVO & 0.550 & 0.604 & 0.577 & 0.684 & 0,773 & 0.866 & 0.288 & 0.399 & 0.599 & 0.477 & 0.568 & 0.703 \\
\hline CÁNDIDO GODÓI & 0.531 & 0.621 & 0.720 & 0.750 & 0,843 & 0,853 & 0.294 & 0.518 & 0.027 & 0.491 & 0.647 & 0,728 \\
\hline CATUIPE & 0.636 & 0.657 & 0.765 & 0.754 & 0,855 & 0,842 & 0,332 & 0,459 & 0.027 & 0.542 & 0,55 & 0.739 \\
\hline CERROLARGO & 0.581 & 0.661 & 0.752 & 0.767 & 0.818 & 0.849 & 0.356 & 0.542 & 0.998 & 0.541 & 0.564 & 0,764 \\
\hline CHIA PEIT A & 0.585 & 0.607 & 0.702 & 0.720 & 0,801 & 0.850 & 0.29 & 0.458 & 0,657 & 0.496 & 0.606 & 0.732 \\
\hline CONDOR & 0.580 & 0.654 & 0.735 & 0.754 & 0.792 & 0.852 & 0.242 & 0.436 & 0,666 & 0.473 & 0.609 & 0.747 \\
\hline CORONEL RARROS & 0.565 & 0,642 & 0.793 & 0.762 & Q.811 & 0,852 & 0.213 & Q.441 & 0.61 & 0.451 & 0.612 & 0,744 \\
\hline CORONEL BICACO & 0.543 & 0.624 & 0.567 & 0.716 & 0.777 & 0,803 & 0.226 & 0.400 & 0.550 & 0.445 & 0.579 & 0.665 \\
\hline CRISSILMAAL & 0.568 & 0.610 & 0.702 & 0.727 & 0.773 & 0.835 & 0.250 & 0.433 & 0.616 & 0.459 & 0.589 & 0.712 \\
\hline DERRUBADAS & 0.436 & 0.613 & 0.664 & 0.710 & 0.751 & 0.845 & 0.152 & 0.409 & 0.28 & 0.361 & 0.573 & 0.707 \\
\hline DEZ ESSEIS DE NOVEMBRO & 0,474 & 0.536 & 0.025 & 0,639 & 0,774 & 0,809 & 0.208 & 0.356 & 0.553 & 0,408 & 0.529 & 0.654 \\
\hline DOUTOR MLALRICTOCARDOSO & 0.549 & 0.611 & 0.707 & 0.721 & 0.790 & 0.840 & 0.285 & 0.570 & 0.593 & 0,482 & 0.65 & 0.706 \\
\hline ENT RE-IUUis & 0.561 & 0.593 & 0.092 & 0.745 & 0.782 & 0,820 & 0.253 & 0.440 & 0.548 & 0.473 & 0.589 & 0.68 \\
\hline ESPERANCAA DOSUL & 0.490 & 0.526 & 0.665 & 0.651 & 0.751 & 0.788 & 0.198 & 0.312 & 0.550 & 0.398 & 0.498 & 0.651 \\
\hline EUGFANTO DECASTRO & 0.56 & 0,620 & 0,697 & 0.760 & 0.854 & 0.885 & 0.241 & 0.445 & 0.584 & 0,459 & 0.21 & 0.712 \\
\hline GARRUCHOS & 0.453 & 0.555 & 0.657 & 0.681 & 0.775 & 0.833 & 2.052 & 0.384 & 0.553 & 0.252 & 0.549 & 0.671 \\
\hline GRUÁ & 0.578 & 0.651 & 0.707 & 0.684 & 0.758 & 0.842 & 0.278 & 0,498 & 0,000 & 0.479 & 0,026 & 0,721 \\
\hline GUARAN DAS MISSÖES & 0.561 & 0.603 & 0.58 & 0.727 & 0.771 & 0.865 & 0.257 & 0.445 & 0.065 & 0,471 & 0.592 & 0,737 \\
\hline HCRIZCNTINA & 0.628 & 0.695 & 0.782 & 0.750 & 0.850 & 0.858 & 0.390 & 0,645 & 0,716 & 0.568 & 0.725 & 0.789 \\
\hline HUMAIT A & 0.585 & 0.642 & 0.732 & 0.782 & 0.802 & 0,837 & 0.349 & 0.509 & 0.657 & 0.538 & 0.64 & 0.738 \\
\hline INLFPENLÉNCIA & 0.539 & 0.644 & 0.711 & 0.745 & 0.793 & 0.813 & 0.251 & 0.425 & 0.576 & 0.455 & 0.501 & 0.659 \\
\hline INHACORÁ & 0.537 & 0.598 & 0.647 & 0.716 & 0.777 & 0.807 & 0.131 & 0.365 & 0.585 & 0.369 & 0.554 & 0.673 \\
\hline JOIA & 0.545 & 0.610 & 0.071 & 0.714 & 0.784 & 0,841 & 0.234 & 0.422 & 0.572 & 0.45 & 0.587 & 0.685 \\
\hline MATO CUEMAADO & 0,494 & 0.604 & 0,702 & 0.750 & 0,853 & 0.870 & 0.261 & 0,457 & 0.603 & 0.451 & 0.617 & 0.717 \\
\hline MIRAGUAI & 0.506 & 0.561 & 0.744 & 0.706 & 0.795 & 0,837 & 0.196 & 0.447 & 0.013 & 0.412 & 0.584 & 0.725 \\
\hline NOVA CANDEL ÁRIA & 0,494 & 0.639 & 0.794 & 0.743 & 0.841 & 0.855 & 0.156 & 0,408 & 0,643 & 0.385 & 0.603 & 0.759 \\
\hline NOVA RAMADA & 0.65 & 0.641 & 0.752 & 0.720 & 0.782 & 0.847 & 0.151 & 0.381 & 0.642 & 0.416 & 0.576 & 0.742 \\
\hline NOVO MLACHADO & 0.530 & 0.597 & 0.544 & 0.738 & 0.777 & 0,796 & 0.228 & 0,379 & 0.543 & 0.447 & 0.56 & 0.605 \\
\hline PEIUCARA & 0.642 & 0.681 & 0.724 & 0.720 & 0.773 & 0.867 & 0.345 & 0.522 & 0,648 & 0.542 & 0.65 & 0,741 \\
\hline PIRAPÓ & 0,456 & 0.536 & 0.656 & 0.684 & 0.738 & 0.824 & 0.188 & 0,378 & 0.553 & 0.391 & 0.531 & 0.669 \\
\hline PORTO LUCENA & 0.509 & 0.591 & 0,700 & 0.705 & 0.786 & 0.827 & 0.232 & 0.416 & 0.575 & 0.437 & 0.578 & 0.693 \\
\hline PORTOMAAUÁ & 0.511 & 0.584 & 0.672 & 0.735 & 0,777 & 0.831 & 0.284 & 0.459 & 0,008 & 0.474 & 0,593 & 0,698 \\
\hline PORTO VERA CRUZ & 0.464 & 0.538 & 0.061 & 0.730 & 0.770 & 0.827 & 0.198 & 0.385 & 0.000 & 0.406 & 0.544 & 0.69 \\
\hline PORTO XAVIER & 0.581 & 0,641 & 0.687 & 0.747 & 0,801 & 0,876 & 0.271 & 0.455 & 0,028 & 0,49 & 0.616 & 0.723 \\
\hline REDENT CRA & 0.491 & 0.506 & 0.506 & 0.023 & 0093 & 0.792 & 0.140 & 0.285 & 0.523 & 0.35 & 0.454 & 0.631 \\
\hline ROL.ADOR & 0.454 & 0.593 & $0,5 \pi 6$ & 0.745 & 0.788 & 0.834 & 0.145 & 0.423 & 0.579 & 0.365 & 0.583 & 0.629 \\
\hline ROQUE GONZALES & 0.528 & 0.594 & 0.687 & 0.717 & 0.769 & 0.843 & 0.237 & 0.399 & 0.58 & 0.448 & 0.567 & 0,688 \\
\hline SAIVADORDAS MISSOES & 0.542 & 0.627 & 0.710 & 0,709 & 0,792 & 0.851 & $0.3 \Omega$ & 0.557 & 0,706 & 0.518 & 0.655 & 0.753 \\
\hline SANTOANT CANIODAS MISSOES & 0.551 & 0.606 & 0.072 & 0.710 & 0.748 & 0.835 & 0.210 & $Q, 436$ & 0.576 & 0.435 & 0.582 & 0.686 \\
\hline SANTOAUGUSTO & 0.616 & 0.641 & 0.753 & 0,700 & 0.801 & 0.840 & 0.256 & 0,430 & 0,07 & 0.48 & 0.627 & 0.739 \\
\hline S.ANTOCRISTO & 0.570 & 0,643 & 0.745 & 0.734 & 0.734 & 0.820 & 0,304 & 0.535 & 0,556 & 0.503 & 0.642 & Q.738 \\
\hline SAO JOSÉ DO INHACORÁ & 0.517 & 0,609 & 0.723 & 0.750 & 0.793 & 0.822 & 0.221 & 0.451 & 0.702 & 0.441 & 0.002 & 0.747 \\
\hline SAOMAARTINHO & 0.525 & 0,68 & 0,734 & 0.720 & 0.759 & 0.830 & 0.275 & 0.515 & 0.028 & 0,47 & 2058 & 0,726 \\
\hline SAO MIIGUEL DAS MIISSCES & 0.527 & 0.657 & 0.574 & 0.673 & 0.772 & 0.821 & 0.184 & 0.360 & 0.537 & 0.403 & 0.57 & 0.657 \\
\hline SAONICOLAU & 0.537 & 0.549 & 0.658 & 0.694 & 0.733 & 0.778 & 0.16 & 0,343 & 0.523 & 0.393 & 0.517 & Q.645 \\
\hline SAO PAULO DAS MISSOES & 0.492 & 0.568 & 0.688 & 0.717 & 0.776 & 0,825 & 0.243 & 0,413 & 0.584 & 0.441 & 0.567 & 0,692 \\
\hline SAO PEDRODOBUTLÁ & 0.607 & 0.642 & 0.750 & 0.748 & 0,793 & 0.843 & 0.373 & 0,580 & 0,694 & 0.553 & 0.666 & 0.76 \\
\hline SAO VAIÉRIO DO SUL & 0.470 & 0.554 & 0.574 & 0.716 & 0,777 & 0.816 & 0.238 & 0.349 & 0.450 & 0.431 & 0.532 & 0,642 \\
\hline SEDENOVA & 0.532 & 0.611 & 0.751 & 0.734 & 0.793 & 0.885 & 0.220 & 0.384 & 0.543 & 0.451 & 0.571 & 0.712 \\
\hline SENADCR SALGADOFILHO & 0.493 & 0.583 & 0.701 & 0.720 & 0.768 & 0.817 & 0.171 & 0.458 & 0.581 & 0.393 & 0.59 & 0.693 \\
\hline SETEDE SET EMIRRO & 0.468 & 0.552 & 0.682 & 0.717 & $a, 779$ & 0.810 & 0.175 & 0.35 & 0.577 & 0.389 & 0.532 & 0.689 \\
\hline TENENTEPORTELA & 0.547 & 0.609 & 0.709 & 0.711 & 0.749 & 0.830 & 0.285 & 0.491 & 0.603 & 0,48 & 0.607 & 0.708 \\
\hline TIRADENTES DO SUL & 0.484 & 0.577 & 0,705 & 0.734 & 0.783 & 0.815 & 0.170 & 0.370 & 0.50 & 0.392 & 0.551 & 0.690 \\
\hline TUCUNDUVA & 0.632 & 0.602 & 0.748 & 0.750 & 0,793 & 0.816 & 0.374 & 0,549 & 0.682 & 0.562 & 0.661 & 0.747 \\
\hline TUPARENDI & 0.58 & 0.650 & 0.734 & 0.750 & 0.794 & 0.832 & 0.288 & 0.506 & 0.02 & 0.495 & 0.642 & 0.728 \\
\hline URIRET AMA & 0.497 & 0.553 & $0 \cong 1$ & 0.720 & 0.788 & 0.809 & 0.226 & 0.390 & 0.623 & 0.432 & 0.554 & 0.7 \\
\hline VIST A GAÚCHA & 0.523 & 0.622 & 0,774 & 0.720 & 0.766 & 0.839 & 0.250 & 0.499 & 0,609 & 0,451 & 0,619 & 0.757 \\
\hline VITCRIA DAS MISSCES & 0.547 & 0.542 & 0.659 & 0.707 & 0.774 & 0.800 & 0.209 & 0.410 & 0.526 & 0.432 & 0.556 & 0.655 \\
\hline
\end{tabular}

Fonte: PNUD (2013). Dados organizados pelos autores.

Essa mudança nos indicadores de desenvolvimento possui uma vinculação importante com os recursos do fundo público aplicado em políticas sociais. Por mais que os críticos apontem a dificuldade em estabelecer, de forma objetiva, estas vinculações, não encontram-se transformações significativas na estrutura de propriedade, de classes ou de valorização do trabalho capazes de explicar as mudanças ocorridas. As políticas sociais, na medida em que expandem sua abrangência à toda a população, são capazes de impulsionar o desenvolvimento, tornado visível por meio dos indicadores aferidos.

\section{CONSIDERACÕES FINAIS}

A pesquisa sobre a aplicação do fundo público nos pequenos municípios do Noroeste do RS tem apontado um tendência expressiva (acima dos 500\%) de crescimento dos valores totais aplicados ao longo do período analisado. Os percentuais aplicados cresceram em 88,6\% dos municípios. Existem evidências claras de repercussões importantes nos indicadores de desenvolvimento dos mesmos, de forma especial nos aspectos ligados à longevidade e à educação. Porém, também evidencia-se o acirramento da disputa pelo fundo público, na medida em que o crescimento dos valores aplicados em políticas sociais, em muitos municípios, não tem sido no mesmo ritmo do orçamento total disponível. 
É evidente que, para pequenos municípios, especialmente em regiões periféricas no cenário econômico estadual e nacional, os recursos do fundo público são estratégicos na promoção do desenvolvimento. Orientá-los no sentido do estabelecimento de políticas públicas que beneficiem a todos torna-se um grande desafio, pois o jogo de forças, no cenário local, não está imune à lógica de reprodução do capital. As disputas políticas pelo controle do Estado (nas diferentes esferas) e das instâncias deliberativas da sociedade civil tornam-se imperativos na defesa de propostas de desenvolvimento inclusivas, democráticas e que garantam qualidade de vida para todos.

\section{REFERÊNCIAS}

[1] Bardin, Laurence. Análise de Conteúdo. Tradução de Luiz Antero Reto e Augusto Pinheiro. Lisboa: Edições 70, 1979.

[2] Behring, Elaine R.; Boschetti, Ivanete. Política social: fundamentos e história. São Paulo: Cortez, 2006.

[3] Brasil - Tesouro Nacional. Finbra - Finanças do Brasil - Dados Contábeis dos Municípios. Brasília: STN, 2013. Disponível em: <http://www,tesouro.fazenda.gov.br/contas-anuais>. Acesso em: 12 set. 2016.

[4] Brasil - Tesouro Nacional. Siconfi - Sistema de Informações Contábeis e Fiscais do Setor Público Brasileiro. Brasília: Tesouro Nacional, 2016. Disponível em: <https://siconfi.tesouro.gov.br/siconfi/index.jsf>. Acesso em: 12 set. 2016.

[5] Castro, Jorge A. Política social e desenvolvimento no Brasil. Economia e Sociedade, Campinas, v. 21, Número Especial, p. 1011-1042, dez. 2012.

[6] Cnm - Confederação Nacional de Municípios. Planos Diretores para municípios de pequeno porte: limites e perspectivas para a aplicação dos instrumentos do Estatuto da Cidade. Brasília: Cnm, 2015.

[7] Faleiros, Vicente de P. A política social do estado capitalista. 8.ed. rev. São Paulo: Cortez, 2000.

[8] Ibge - Instituto Brasileiro de Geografia e Estatística. Estimativas da população residente para os municípios de para as unidades da federação brasileiros com data de referência em 1o de julho de 2017. Rio de Janeiro: IBGE, 2017. Disponível em: <https://biblioteca.ibge.gov.br/visualizacao/livros/liv100923.pdf>. Acesso em: 23 jan. 2018.

[9] Lenza, Pedro. Direito constitucional esquematizado. 17 ed. rev. atual. e ampl. São Paulo: Saraiva, 2013.

[10] Netto, José P. Capitalismo monopolista e serviço social. São Paulo, Cortez, 1992.

[11] Pastorini, Alejandra. Quem mexe os fios das políticas sociais? Avanços e limites da categoria concessãoconquista. Serviço Social \& Sociedade, São Paulo, ano XVIII, n. 53, p. 80-101, mar. 1997.

[12] Pfeifer, Mariana. O "social" no interior do projeto neodesenvolvimentista. Serviço Social e Sociedade, São Paulo, n. 120, p. 746-766, out./dez. 2014.

[13] Pnud - Programa das Nações Unidas para o Desenvolvimento. Atlas do Desenvolvimento Humano no Brasil. Brasília: PNUD, 2013. Disponível em: < http://www.atlasbrasil.org.br/2013>. Acesso em: 23 setembro 2015.

[14] Rio Grande do Sul. Perfis - Regiões Funcionais de Planejamento. Porto Alegre: Seplan-Rs/Deplan, 2015.

[15] Rotta, Edemar. Desenvolvimento regional e políticas sociais no noroeste do estado do Rio Grande do Sul. Tese (Doutorado em Serviço Social), PPGSS/PUCRS, Porto Alegre, 2007.

[16] Rotta, Edemar; Lago, Ivann C; Rossini, Neusa. Disputa pelo fundo público municipal: as políticas sociais na trajetória de duas décadas no Noroeste do Rio Grande do Sul. Textos \& Contextos, Porto Alegre, v. 16, n. 2, p. 495-510, ago./dez. $2017 . \quad$ Disponível em: <http://revistaseletronicas.pucrs.br/fass/ojs/index.php/fass/article/view/27554/16427>. Acesso em: 05 jan. 2018.

[17] Sachs, Ignacy. Desenvolvimento: includente, sustentável, sustentado. Rio de Janeiro: Garamond, 2004.

[18] Salvador, Evilásio. Fundo Público e o financiamento das Políticas Sociais no Brasil. Serv. Soc. Rev., Londrina, v. 14, n.2, p. 04-22, Jan./Jun. 2012. Disponível em: <file:///C:/Users/UFFS/Downloads/12263-54920-1-PB.pdf>. Acesso em: 28 abril 2017.

[19] Silva, Maria O. S. (Coord.). Programas de transferência de renda na América Latina e Caribe. São Paulo: Cortez, 2014. 


\section{Capítulo 8}

\section{A política de assistência social como determinante estratégico no combate à pobreza no Brasil}

\section{Ana Virginia do Nascimento Moreira \\ Amanda Maria Cunha Menezes}

Resumo: 0 artigo realiza um estudo da política de assistência social no Brasil, buscando captar suas tendências e contra tendências no embate à pobreza, no contexto de capitalismo dependente. Através do estudo bibliográfico, buscou-se trazer de forma breve o debate sobre o capitalismo dependente no qual o Brasil ocupa lugar central na América Latina, bem como as determinações econômicas, ideológicas e políticas que estabelecem as atuais tendências em torno da materialização da política de assistência social. No contexto de mudanças e reestruturação do capitalismo, a classe trabalhadora sofre com a precarização da sua condição e agravamento da pobreza. Neste cenário de enfraquecimento do neoliberalismo e ameaça de revolta da classe trabalhadora, o capitalismo assume uma nova face, pautada na ideologia burguesa social-liberal, que propõe intervenções com foco na pobreza, onde as ações do Estado são ampliadas aos interesses do mercado e acumulação do capital e reduzidas ao atendimento das necessidades da classe trabalhadora limitando-se a manter esta classe sob controle. Logo, a política de assistência social no Brasil, recentemente legitimada como direito, é a eleita pelo Estado a assumir a responsabilidade de atuar sobre a pobreza extrema seguindo as orientações das agências internacionais, o que constitui uma dicotomia entre a universalidade proposta pela Constituição Federal de 1988 e os ditames da ideologia burguesa dominante.

Palavras-Chave: Capitalismo dependente. Ideologia burguesa. Política de Assistência Social. Pobreza. 


\section{INTRODUÇÃO}

Este artigo buscou realizar uma aproximação dos debates em torno da política de assistência social, enquanto elemento estratégico no combate à pobreza no Brasil. Tal estudo teve como ponto de partida as particularidades do capitalismo periférico no Brasil, diante do cenário internacional ao qual o país sempre esteve submetido. Dessa forma, entendemos como essencial tal debate para compreender o atual quadro de agravamento da pobreza no país. Em seguida, buscamos abordar a direção ideológica burguesa diante das respostas dadas à pobreza, as quais refletem sobre as ações da política de assistência social.

Na busca pela construção do debate proposto, observamos que as contradições socioeconômicas do capitalismo periférico brasileiro levaram ao incentivo da expansão da política de assistência social devido o quadro de agravamento da pobreza, considerando o não isolamento brasileiro diante do contexto turbulento pós-crise de 1970, afetando a economia mundial. Cabe ressaltar ainda os impactos da globalização quem põem em xeque a democracia por meio da eliminação dos direitos conquistados pelos trabalhadores, assim como impõem a precarização e flexibilização do trabalho.

É necessário entender os elementos que constituem a globalização, os quais ditam novas formatações para o trabalho através da imposição da ideologia dominante burguesa sob estratégias pensadas para manter a classe trabalhadora, empobrecida, explorada e sem direitos, sob controle. Essas novas formas ideológicas, a exemplo do pensamento social-liberalista ${ }^{23}$, orientam a ação do Estado mediante o contexto em que se consolida.

No caso brasileiro, as particularidades no processo de constituição do Estado (considerado por alguns autores como Estado de Bem-Estar Social) e do capitalismo [dependente] conferem um amplo espaço para disseminação dessas ideologias que, segundo Silveira Jr. (2016, p. 68) "[...] são perceptíveis enquanto mediações de relações sociais concretas e determinadas". No intuito de entender as políticas sociais no Brasil, Yazbek (2016) chama a atenção para os elementos contraditórios que permeiam as ações do Estado brasileiro, principalmente no tratamento da pobreza no Brasil. Neste contexto, a política de assistência social é eleita como a grande responsável pelo combate à pobreza.

0 grande marco legal da consolidação da assistência social brasileira enquanto direito social é a Constituição Federal de 1988. Esse conjunto de leis foi responsável em pôr no horizonte da sociedade brasileira a possibilidade de construção de um sistema de seguridade social público e universal que comportava, ainda que de maneira limitada, um importante avanço para os trabalhadores brasileiros. A Constituição de 1988 incorporava, pela primeira vez na história do Brasil, um conjunto de direitos que sinalizavam para a possível consolidação de um sistema de proteção social aglutinando em seu escopo políticas de previdência, saúde e assistência social (MARANHÃO, 2004, 11).

Desta maneira, o Estado atua na reprodução do capital, com ausência de direitos efetivamente universais, e desempenha um papel fundamental no capitalismo: o de legitimar a precarização e flexibilização das leis trabalhistas. Segundo Yazbek (2016, p. 54) "[...] o Estado sempre esteve presente na articulação do capitalismo no Brasil". A autora aponta ainda que as mudanças no âmbito social, econômico e político, principalmente nas últimas três décadas, trazem novas configurações ao Estado, como um Estado de MalEstar Social.

Essa integração, que é intrínseca à historicidade do capitalismo na economia, adicionou ao Estado brasileiro características burocráticas. Yazbek (2016) é enfática ao afirmar que ao avançar na economia, a desigualdade continuou se expandindo e o Estado brasileiro para garantir sua legitimidade desenvolveu ações que embora tocassem a desigualdade social, não atuaram no intuito enfrentar ou superar a mesma.

Neste enfoque, no campo social, as políticas públicas implementadas não avançaram no sentido de combater as desigualdades sociais, embora sejam o marco das conquistas dos movimentos sociais, possibilitando apenas que o usuário tenha acesso ao mercado e movimente a economia. Entre as estratégias tomadas, verificou-se que reagir ao crescimento da pobreza no Brasil com políticas sociais compensatórias e focalistas traria resultados mais acelerados. Assim, tomou-se como medida distribuir renda, principalmente através dos programas de transferência de renda no país, o que marca o período

23 "O social-liberalismo surge no cenário internacional em um quadrante histórico determinado pela consolidação da mundialização financeira, das lutas de classes anti-sistêmicas dos movimentos sociais e do aumento das desigualdades sociais entre classes, países e regiões do planeta" (BRANCO, 2008, p. 24). 
das políticas de assistência social compensatórias, ou seja, a junção do econômico e o social para lidar com o pauperismo crescente.

\subsection{CAPITALISMO PERIFÉRICO NO BRASIL: ELEMENTOS DETERMINANTES PARA A COMPREENSÃO DA POBREZA}

A atual conjuntura econômica, política e social têm agravado o processo mundial de empobrecimento do trabalhador via precarização do trabalho e redução de direitos. Estes determinantes são cruciais para compreender o processo de intensificação das desigualdades sociais, da violência e do individualismo, na mesma proporção que se amplia a riqueza concentrada nas mãos da classe dominante. Segundo Teixeira e Neves (2018, p. 133), "não se trata de meramente caos nos dias atuais, visto que a produção coletiva da riqueza e sua apropriação privada é pilar central no exercício de podres poderes da ordem burguesa".

A financeirização da economia levou ao fechamento de fábricas e a redução do número de empregos qualificados nas economias capitalistas avançadas, aumentando o número de ocupações desprotegidas e ampliando a força de trabalho sub-remunerada nos países semiperiféricos (BRAGA, 2017, p. 31). Martin (1997), ao relatar sobre uma reunião realizada pela "elite do mundo"24, afirmou que buscava-se pensar novos caminhos para a sociedade capitalista, num contexto de ameaça à hegemonia burguesa e devido à crise estrutural que se instalou em 1970. Este debate teve como primeiro eixo a temática: tecnologia e trabalho na economia global.

Neste eixo, defende-se novas formas de trabalho no mundo capitalista, onde os capitalistas afirmaram que: “[...] cada qual pode trabalhar conosco quanto tempo quiser, também não precisamos de vistos para nosso pessoal do exterior" (MARTIN, 1997, p. 9) Nessa situação, utilizando-se do mundo da informática por exemplo, o trabalhador passaria a exercer suas atividades laborativas em casa, sem uma jornada de trabalho definida, o que significaria uma extensão da jornada de trabalho.

Segundo Teixeira e Neves (2018) o processo de exploração do trabalho (na atual fase do capital, com destaque aos países de economia dependentes), consiste numa estratégia do capital para revigorar-se, combinada ao rebaixamento salarial, derrocada dos direitos trabalhistas, fim dos contratos formais, intensificação das jornadas de trabalho, focalização das políticas públicas, entre outros elementos. A classe trabalhadora passa a ocupar-se em trabalhos mais precários e desprotegidos, principalmente após a legitimação da precarização pelo Estado, através das políticas públicas voltadas para o aceleramento do mercado.

Os pragmáticos reunidos no Fairmont resumem o futuro em um par de número e neologismo: "20 por 80" e em "tittytainment". Vinte por cento da população em condições de trabalhar no século 21 bastariam para manter o ritmo da economia mundial. "Mão-de-obra adicional não será necessária", opina o magnata Washington SyCip. Um quinto de todos os candidatos a emprego daria conta de produzir todas as mercadorias e prestar todos os serviços qualificados que a sociedade mundial poderá demandar. Assim, aqueles $20 \%$ participariam ativamente da vida, do lazer e do consumo - seja qual for o país. Outros $1 \%$ ou $2 \%$, admitem os debatedores, poderão ser acrescentados por parte daqueles que herdam alguma fortuna (MARTIN, 1997, p. 10-11).

Desta maneira, na sociedade 20 por 80 , um alto contingente da população ficará desempregada, ou seja, $80 \%$ dos trabalhadores estarão aptos para o mercado sem perspectiva de serem absorvidos de volta, uma vez que a tendência é que esses $20 \%$ que são capazes de manter o ritmo da economia mundial cada vez mais diminua ou torne-se mais flexibilizado.

O segundo eixo de debate no encontro têm por temática: o futuro do trabalho. Neste eixo, o foco encontrase naqueles que irão ficar sem emprego. 0 autor afirma que muitos destes desempregados são aqueles que “[...] sentiam-se mais próximos do conforto e da ascensão social do que da luta cotidiana pela sobrevivência" (MARTIN, 1997, p. 11), ou seja, a classe que era estável no mercado de trabalho. Estes eixos refletem nas novas formas que o trabalho vem assumindo na atualidade, com as mudanças no capitalismo.

Aqui, é necessário então investir em "entretenimento" através, por exemplo, da diversão anestesiante (fé, internet, televisão para a massa) e alimento; como também, o empreendedorismo que ilude e entretém as

24 Ocorreu em 1995, Mikhail Gorbachev recepcionou os "donos do mundo" (como o autor chama) que eram representantes das grandes corporações mundiais, para a Fundação Gorbachev. 
massas. Outra forma de entretenimento, seria o incentivo aos programas de transferência de renda (incentivo vindo do Banco Mundial, por exemplo), onde "[...] a vasta legião de frustrados e excluídos poderia ser mantida satisfeita" (MARTIN, 1997, p. 12). Estas discussões de estratégias para manter a população supérflua entretida se dá pelo entendimento de que essa lógica para o trabalho de 20 por 80 necessita de meios para manter os $80 \%$ desempregados controlados, através do entretenimento ofertado essencialmente pelo Estado.

Com a globalização, o mercado mundial assumi novas conotações. Passa-se a investir em altas tecnologias e buscar força de trabalho desvalorizada em países considerados pobres. 0 cenário é de cortes nos direitos sociais dos trabalhadores e diminuição de seus ganhos. Além disto, defende-se o fim do Estado de BemEstar, considerado como uma ameaça. Têm-se a implementação do neoliberalismo defendendo que: "[...] o mercado é bom e as interferências do Estado são ruins" (MARTIN, 1997, p. 17). Inicia-se a defesa pela desregulamentação do Estado, das privatizações e pela liberação do comércio, apoiados por organizações internacionais como o Banco Mundial.

Neste contexto, as mudanças promovidas pelos países centrais que geram uma diminuição da segurança em relação aos contratos de trabalho, devido a retração dos direitos trabalhistas, colocam em cena o declínio do movimento sindical, simbolizando uma perda da influência política dos trabalhadores. Considerando este momento de declínio do trabalho, percebe-se que o aumento do desemprego, num período de instabilidade, leva a expansão da informalidade, que por conseguinte caracteriza o afastamento da proteção trabalhista, consequência da intensificação da rotatividade do mercado de trabalho. Assim, chega-se a era do subemprego ${ }^{25}$.

Em síntese, entendemos que a expressão "Sul global" contém uma dimensão explicitamente política, atada aos protestos e às denúncias das relações de exploração, opressão e espoliação impostas pelo Norte global à semiperiferia do sistema, os quais intensificaram as tensões entre a forma democrática da regulação política e a dimensão autoritária do regime de acumulação financeirizado. Essa tensão tem estimulado diferentes movimentos sociais de contestação à atual globalização capitalista (BRAGA, 2017, p. 31).

Após o final da década 1980, a América Latina vivia um processo democrático, no sentido de superação das ditaduras militares e de reação contra o neoliberalismo. Neste contexto, vários governos de centroesquerda e esquerda subiram ao poder, como é o caso do Brasil. No cenário econômico e político destes países presenciava-se ainda os reflexos da crise mundial iniciada em 1970, que acabou por determinar mudanças em vários países. A fim de se reestruturarem, iniciou-se a contrarreforma neoliberal do Estado, “[...] orientada por ideologias que afirmam o fim da história, da centralidade do trabalho e do Estado regulador, ao tempo em que defende o mercado como mecanismo de regulação, entre outras argumentações" (MOTA, AMARAL, PERUZZO, 2012, p. 154).

As saídas adotadas pelos capitais internacionais para restaurar/aumentar os níveis de acumulação e valorização em todos os países de economia capitalista vão desde o desenvolvimento de novas tecnologias, restrição de direitos trabalhistas e outras conquistas sociais até uma forte ofensiva, junto aos países periféricos, no sentido de estes contribuírem, de modo mais direto, na transferência de excedentes do valor (MOTA, AMARAL, PERUZZO, 2012, p. 154).

Em 1990, os governantes passaram a defender o projeto que tinha como princípio o crescimento econômico com desenvolvimento social, seguindo as premissas de pensadores como Amartya Sen. Os países latinos americanos não puderam opor-se ainda ao processo de internacionalização da economia e à nova etapa do capital: a especulativa. Neste contexto, observa-se ainda a fundamental ação do Estado no sentido de criar políticas de isenção fiscal e de financiamentos, a fim de atrair a indústria e incentivar a economia nacional no período de implementação do novo desenvolvimentismo nos países latinos americanos $^{26}$.

\footnotetext{
25 Braga (2017) afirma que o subemprego parte do conflito entre a regulação e acumulação econômica pelo aprofundamento da mercantilização do trabalho.

26 "Nos anos 2000, os governantes ou candidatos que pleiteavam a representação dos chamados setores progressistas da sociedade chegam ao poder com posicionamento anti-imperialistas e a defesa do desenvolvimento nacional, compreendido como um meio de autonomia dos estados nacionais. Não se trata de uma repetição do desenvolvimentismo nacional dos anos 1960, mas da defesa de um desenvolvimento autossustentável desde o ponto de vista econômico e social" (MOTA, AMARAL, PERUZZO, 2012, p. 154).
} 
Para compreender como se dá a acumulação capitalista nas economias dos países periféricos e sua posição de dependência deve-se pensar a partir do entendimento do sistema de relações mundiais que compõem os mercados e as produções capitalistas. Estas relações de dependência nos países periféricos se dá através dos processos históricos de formação das suas bases econômicas, sociais e políticas. No Brasil, o capitalismo se caracteriza como dependente, desigual e submisso aos países de capitalismo central. Não esteve imune aos determinantes econômicos e políticos dos países de capitalismo central devido ao processo de globalização ao qual está submetido. Os reflexos da crise de 1970 puderam ser sentidos nos países de capitalismo periférico, incluindo o Brasil.

A acumulação do capital no Brasil de capitalismo dependente exprime certas contradições que lhe são essenciais na reprodução das relações de produção: de um lado, a dinâmica da exploração do trabalho se exacerba cada vez mais mesmo com o desenvolvimento e ampliação de 'modernas' indústrias e relações de trabalho capitalistas, de outro lado, o antagonismo entre capital e trabalho, que se expressa sobremaneira na relação contraditória central entre socialização da produção e apropriação privada da riqueza produzida, se materializa numa enorme desigualdade social e de renda, com impactos diretos na reprodução da força de trabalho (TEIXEIRA; NEVES, 2018, p. 135-136).

Desta maneira, devemos pensar a burguesia nacional diante do quadro do capitalismo mundial, devido a intensificação do processo de internacionalização da nossa economia e das influências ideológicas dos pensadores burgueses oriundos dos países de capitalismo central, os quais estabelecem ideias que acentuam ainda mais a condição de submissão dos países periféricos. Este cenário é importante para pensar o processo de empobrecimento da classe trabalhadora, que agora passa a ser usuária da política de assistência social e acaba sendo submetida às medidas impostas de entretenimento, onde a classe dominante cria meios de garantir a sua hegemonia.

\section{A DIREÇÃO IDEOLÓGICA BURGUESA PARA AS RESPOSTAS À POBREZA}

No século XXI o capital demonstra o seu "potencial" em explorar o trabalho para a produção em larga escala de riqueza, enquanto nos defrontamos com a expansão global das desigualdades sociais. Mediante este contexto, há um movimento da classe dominante em pensar estratégias para o embate do pauperismo crescente, no intuito de conter uma possível desordem ou instabilidade do capitalismo. Sendo assim, vários órgãos internacionais passam a investigar os desdobramentos das expressões da questão social, buscando desenvolver a ideia de uma face humanitária do capital globalizado (BRANCO, 2008).

Em sua retomada histórica acerca da ideologia do pensamento burguês, Branco (2008) parafraseando Karl Marx aponta a sua tese sobre a decadência do pensamento deste segmento ${ }^{27}$. Neste processo, além de os pensadores burgueses realizarem uma análise superficial da base econômica, deixaram de revelar as contradições e determinantes estruturais que compõe a realidade social no sistema capitalista. Ou seja, as resoluções para problemáticas da sociedade não poderiam partir de análises críticas do sistema capitalista, mas de medidas paliativas que não interferisse nas estruturas do capital nem colocassem em perigo a soberania burguesa. Esta forma de interpretar a realidade social pelos pensadores burgueses se perpetua até hoje. Partindo desta premissa, de mudança e introjecção do conservadorismo na classe dominante burguesa, buscaremos explicar as premissas sociais-liberais.

No Brasil, no período pós crise de 1970 vê-se entrar em cena a sombra do neoliberalismo como um projeto hegemônico das classes dominantes através de governos conservadores. Sua doutrina defendia o controle de gastos públicos (Estado mínimo), arrocho salarial e supressão de direitos, abertura para o capital financeiro e a privatização. Porém, segundo Branco (2008, p, 23),

0 rigor e a severidade com os quais estes planos de estabilização macroeconômica foram implementados não foram suficientes para garantir os resultados esperados: as contas públicas continuaram deficitárias, as atividades econômicas não foram retomadas, a inflação não foi controlada e os índices de pobreza e desigualdade se deterioraram.

\footnotetext{
27 Durante os processos revolucionários em que a classe burguesa se unia a classe trabalhadora para derrubar a monarquia, era a burguesia quem mais investia em artes e ciência, patrocinando renomados nomes que revolucionaram as suas áreas. Porém, ao obter o poder, segundo Marx, a burguesia entra em decadência ideológica, aderindo aos princípios conservadores, presentes até hoje.
} 
A crise e seus impactos atingem a população, porém, de forma desigual. Em relação aos países, a crise aumentou a diferença econômica entre as regiões, o que se constitui como fator determinante para o agravamento das expressões da questão social e empobrecimento da classe trabalhadora. Segundo Braga (2017, p. 25), "[...] trata-se de uma realidade cujo efeito principal tem sido o aumento dessa desigualdade e o consequente aprofundamento da inquietação social, sobretudo após o advento da crise da globalização".

Para Braga (2017), a crise do fordismo em 1970 e a consolidação da hegemonia neoliberal após a década de 1980 não foram suficientes para conter as formas de regulação do mercado, onde observou-se a introdução de uma nova forma de mercantilização, transparecendo uma maior insegurança econômica e acentuação das desigualdades de classe.

Com a falta de êxito almejado e acirramento das expressões da questão social, que já afetavam o mercado, os capitalistas traçaram uma nova estratégia, iniciada pela ampliação do papel do Estado, o qual passou a ser regulador da economia e operacionalizador de políticas sociais. Isto marca a transição para a segunda fase do neoliberalismo: o social-liberalismo, que defende uma intervenção mais ativa do Estado nas expressões da questão social (BRANCO, 2008).

Em suma, a crise da globalização iniciada em 2008 foi um divisor de águas na política internacional, levando as classes dominantes do Norte global a recorrer ao intervencionismo estatal a fim de tentar estabilizar o sistema. No entanto, uma vez assegurado tal objetivo, voltaram à ofensiva sobre as classes subalternas com uma versão ainda mais crua do neoliberalismo. Os trabalhadores estão pagando a conta da crise por meio de rigorosos planos de austeridade e de padrões de vida cada dia mais baixos. Em poucas palavras, a onda de espoliação neoliberal tende a semear revoltas e multiplicar conflitos de difícil solução nos marcos democráticos tradicionais (BRAGA, 2017, p. 22-23).

Branco (2008) faz um levantamento sobre os pensadores sociais-liberais tupiniquim e suas propostas de intervenção para o pauperismo no Brasil. Inicialmente, os autores afirmam que o Brasil não se consolida como um país pobre, mas um país com muitos pobres, devido à desigualdade na distribuição dos recursos e das oportunidades de inclusão social. Consideram que o Brasil possui disponibilidade de recursos para combater a pobreza.

Segundo Francisco Ferreira, as causas da desigual distribuição de renda entre membros de um país são resultados de cinco grupos de fatores, uns de ordem social, outros de ordem natural-genética: (1) as diferenças nas características natas dos indivíduos (raça, gênero, inteligência e/ ou riqueza inicial); (2) diferenças nas características adquiridas dos indivíduos, como por exemplo, a educação e a experiência profissional; (3) mecanismos do mercado de trabalho (discriminação, segmentação e projeção); (4) imperfeições nos mercados de capitais e; (5) fatores demográficos (fertilidade da população) (BRANCO, 2008, p. 26).

Para os pesadores sociais-liberais, a existência de diferenças "natas" entre indivíduos, devem ser trabalhadas no incentivo de suas "aptidões", preparando o indivíduo para o mercado de trabalho. Ou seja, há um incentivo a qualificação e até mesmo a formação familiar para a garantia de um aumento na renda 28 . Outra medida para o enfrentamento da pobreza, proposta pelos sociais-liberais, é a implementação de políticas sociais compensatórias através da distribuição de renda atingida por intermédio “[...] da alocação eficiente dos recursos escassos já disponíveis" (BRANCO, 2008, p. 27), onde estas políticas seriam operadas pelo Estado e o terceiro setor, buscando "emplacar" desenvolvimento econômico e social, pela via da equidade.

\footnotetext{
28 "De acordo com sua teoria, o primeiro grupo de fatores - acima identificado como as características natas dos indivíduos - constitui-se como a pedra angular da distribuição de renda entre cidadãos de um mesmo país. Fatores de ordem natural, assim, são relacionados como prioritários no entendimento teórico da alocação da riqueza produzida nacionalmente. De posse de suas aptidões inerentes, cada indivíduo passa então a interagir com as instituições educacionais na busca de uma melhor capacitação para, como dizem Paes de Barros e Mendonça, a "preparação para a corrida" do mercado de trabalho. O terceiro momento é a inserção do indivíduo no mercado de trabalho e sua consequente remuneração. Quanto mais apto e melhor qualificado for o indivíduo, diz Ferreira, melhor será a sua remuneração vis-à-vis outros indivíduos menos capazes, menos esforçados e mais desqualificados. Por último, o indivíduo formará o que o autor chama de "clubes de consumo" (os domicílios), no qual a renda poderá aumentar ou diminuir de acordo com suas escolhas matrimoniais e a quantidade de filhos do casal (BRANCO, 2008, p. 26-27)".
} 
Nas teses dos social-liberais, o nó cego reside na ineficiência das políticas sociais. Esta ineficácia ficaria patente quando se constata que o volume de recursos públicos direcionados aos programas sociais não garante a mudança no padrão estrutural da desigualdade social. Eles, então, propõem medidas de cunho administrativo para aumentar a efetividade das políticas sociais: (1) focalização dos gastos sociais nos "mais pobres dos pobres"; (2) avaliação do impacto das políticas sociais e (3) integração e coordenação dos programas sociais em todos os níveis governamentais - federal, estadual e municipal - e do setor privado. Vejamos cada uma das medidas propostas para aumentar a efetividade das políticas sociais (BRANCO, 2008, p. 27-28).

Sendo assim, o foco da política de assistência social, de acordo com os sociais-liberais, estaria na centralização do atendimento para aqueles considerados em situação de pobreza extrema. Outro foco estaria no intuito de garantir uma política educacional mais eficaz, capacitando os trabalhadores para atenderem aos novos requisitos do mercado de trabalho. Com o aumento da pobreza que afeta a classe trabalhadora, as organizações multilaterais adotaram o discurso do combate à pobreza, como medida paralela ao mercado, defendendo que o desenvolvimento não parte apenas do aumento das taxas de lucro, mas também através do crescimento de oportunidades de inclusão social (MARANHÃO, 2012).

O economista-chefe e ex-vice presidente do Banco Mundial Joseph E. Stiglitz (2002), faz um apanhado sobre a busca por "um mundo onde não exista miséria" e aponta que o Banco Mundial (composto por uma equipe de economistas), dedica-se à busca pela erradicação da pobreza tendo como alvo principal os países considerados periféricos, onde as equipes são enviadas para estes países para buscar construir estratégias humanizadas de enfrentamento à pobreza e miséria. Segundo Stiglitz (2002), nestes países fica nítido o grande muro que separa os países ricos dos pobres, principalmente através do contingente de indivíduos em situação de pobreza absoluta ${ }^{29}$.

[...] Mesmo nas regiões onde a cegueira do rio foi eliminada, a pobreza resiste apesar de todas as boas intensões e das promessas feitas pelos países em desenvolvimento, os quais, em sua grande maioria, um dia foram possessões coloniais das nações desenvolvidas (STIGLITZ, 2002, p. 52).

Estas medidas seriam tomadas no sentido de "dar liberdade" para as nações em desenvolvimento, embora, segundo Stiglitz, isso não necessariamente simbolize um rompimento com o peso do processo colonial, que foi um forte fator para o pouco preparo dos países em desenvolvimento para a autonomia. Stiglitz (2002, p. 53) deixa claro que o objetivo não se trata em erradicar a pobreza, mas alcançar "[...] um mundo com menos pobreza".

[...] Via minha tarefa como tríplice: pensar bem sobre quais estratégias seriam mais eficazes para promover o crescimento e reduzir a pobreza; trabalhar com os governos dos países em desenvolvimento para implementar essas estratégias; e fazer tudo o que estiver ao meu alcance dentro dos países desenvolvidos para promover os interesses e as inquietações do mundo em desenvolvimento, exercendo pressão para que abrissem seus mercados ou fornecessem ajuda mais eficaz (STIGLITZ, 2002, p. 53).

Como Stiglitz (2002) defende a medida para diminuição da pobreza? Através da transformação econômica. Ou seja, o Estado passa a atuar sobre as questões da população na mesma proporção em que se cria medidas macroecômicas para acelerar o mercado. Para que o país consiga crescer é necessário balancear o investimento no social com o econômico, a fim de evitar situações de inflação, por exemplo, que comprometem a economia do país e, assim, agravam a situação da população. Sendo assim, o Banco Mundial investe principalmente nos países em desenvolvimento que tenham como alvo ações para os pobres.

Observa-se que, para o Banco Mundial, a maior preocupação estaria no embate da pobreza, fato que coincide com a fala de Branco (2008) ao afirmar o interesse do capitalismo no tratamento das expressões da questão social. Porém, neste caso, qual a crítica que se coloca? A questão de como os pensadores da classe burguesa enxergam a questão social, dando enfoque na pobreza, passa a ser definida apenas em questões monetárias e a abordagem em torno do seu enfrentamento parte desta noção, por isso a política de assistência social assumiu um posto central, pois foi através dela que o Estado pode estabelecer

${ }^{29}$ Para Stiglitz (2002, p. 52), pobreza absoluta é quando há um grande número de pessoas “[...] vivendo com menos de um dólar por dia. 
medidas sobre esta lógica, com políticas sociais especificamente compensatórias e monetárias, divergente com a noção de universalidade prevista na Constituição Federal de 1988.

Outro pensador cuja teoria possui forte influência sobre as medidas do Estado brasileiro, em especial no que cerne a política de assistência social, é o indiano Amartya Kumar Sem. 0 economista e pesquisador da ONU propõe medidas no combate aos quadros de desemprego, pobreza e desigualdades sociais através do desenvolvimento das capacidades dos indivíduos (através da economia de livre mercado desenvolvimento como liberdade) (MARANHÃO, 20012). Foram suas premissas que guiaram ideologicamente os seguidores do novo-desenvolvimentismo.

Entre outras propostas, os adeptos desse novo-desenvolvimentismo consideram que algumas políticas e ações são fundamentais para repor na agenda dos países da região os mecanismos de distribuição dos recursos, de modo a enfrentar a questão da desigualdade, agora com foco na discussão da oportunidade. Assim, tais iniciativas devem: promover a redução da desigualdade com redistribuição, reconhecimento e representação; propiciar o investimento em políticas sociais e educacionais como fatores estratégicos no sentido da inclusão econômica formal de segmentos da população com baixíssimos rendimentos e para a melhoria na distribuição de renda, no sentido de minimizar as assimetrias das desigualdades causadas pela globalização do mercado (SICSÚ, PAULA e MICHEL, 2005 apud MOTA, AMARAL e PERUZZO, 2012, p. 159).

Segundo Maranhão (2012), Amartya Sen demonstra uma preocupação com o aumento da vulnerabilidade social nos países de capitalismo periférico, passando a defender um equilíbrio entre ação do governo, organizações sociais e mercado, de forma integrada (articulação do mercado e equidade). Defende que a pobreza deve ser vista sobre a égide do desenvolvimento das capacidades humanas (foco na liberdade de acesso aos benefícios do mercado - aqui sua teoria se aproxima do social-liberalismo). Para Sen o foco das políticas de desenvolvimento social e humano não estaria na distribuição de renda entre as classes, mas em promover equidade através das oportunidades sociais, com políticas públicas focalizadas nos indivíduos, a fim de trabalhar para que estes tenham acesso ao mercado (poderíamos pensar, neste caso, na política de assistência social, com os programas de transferência de renda e o incentivo ao empreendedorismo).

Sendo assim, de acordo com Amartya Sen a redução da pobreza e desigualdade social devem ocorrer a partir do combate a privação dos indivíduos do acesso livre ao mercado. Isto se daria através do fornecimento de oportunidades sociais para desenvolver as capacidades dos indivíduos e suas habilidades e, assim, incluir os excluídos no mercado de trabalho (MARANHÃO, 2012).

[...] Nessa nova concepção de desenvolvimento, o objetivo das políticas sociais não é mais redistribuir a renda de um país ou região, retirando de quem tem muito e dando a quem tem pouco, mas sim criar um ambiente que ofereça as oportunidades sociais adequadas para que os agentes individuais saiam de sua condição de pobreza e exclusão (MARANHÃO, 2012, p. 95).

Desta maneira, Sen seria um dos maiores influenciadores da construção da política de assistência social no Brasil. As políticas sociais assumiram, de acordo com Sen, uma posição estratégica na busca pelo equilíbrio do mercado, desde que não interfiram no seu desenvolvimento, garantindo apenas o aumento da liberdade de oportunidades aos indivíduos e condições básicas de inserção no mercado. Defende políticas focalizadas e celetistas através de critérios de acesso, de acordo com as deficiências de capacidades individuais e ausência de oportunidades. Por fim, defende uma política social-liberal em que as políticas sociais não interfiram no equilíbrio financeiro (MARANHÃO, 2012).

\section{AS TENDÊNCIAS E DESAFIOS PARA A POLÍTICA DE ASSISTÊNCIA SOCIAL FRENTE AO CENÁRIO DE TRANSFORMAÇÕES DO MUNDO DO TRABALHO}

Com o ajuste neoliberal, os organismos internacionais têm estabelecido recomendações para a gestão da pobreza (ou administração da superpopulação relativa), que atinge tanto a força de trabalho em execução de atividades laborativas quanto os desempregados. Estas estratégias contém as conquistas dos trabalhadores, sem, porém, interferir no processo econômico, investindo em políticas públicas que favoreçam o desempenho do mercado e do social. 
Segundo Mota, Maranhão e Sitcovsky (2010) as políticas de proteção social manifestam as contradições e antagonismos entre as classes sociais, dependendo do nível de socialização política da classe trabalhadora e das estratégias do capital. Diante deste contexto, o usuário da política de assistência social passa a ser, também, o trabalhador precarizado e sua família.

A conjunção entre expansão pública e mercantilização faz parte das proposições neoliberais, postuladas como assecuratórias da equidade, cujo princípio é dar mais a quem tem menos. 0 que chama atenção é a capacidade que tiveram as classes dominantes em capitalizar politicamente a Assistência Social, transformando-a no principal instrumento de enfrentamento crescente pauperização relativa, ampliando o exército industrial de reserva no seio das classes trabalhadoras. Em tal contexto, um dos instrumentos de repolitização da política, como parte da pedagogia da hegemonia, consistiu em definir este segmento de classe como "excluídos" e os programas de Assistência Social como estratégia de inclusão (MOTA, 2010, p. 141).

Segundo Mota (2010), diante das políticas que pertencem à Seguridade Social ${ }^{30}$, no Brasil (saúde, previdência social e assistência social) há um movimento reverso entre elas. Enquanto expande-se o processo de privatização e mercantilização da saúde e previdência social, a assistência social se amplia e torna-se um novo fetiche de enfrentamento à desigualdade social, sendo considerada como a principal forma de proteção social no Brasil.

Governos de esquerda e centro-esquerda na América Latina propõe, então, uma combinação de medidas de incentivo ao crescimento econômico, articuladas à políticas compensatórias, tendo em vista o ataque aos direitos e a precarização do trabalho. Segundo Mota, Amaral e Peruzzo (2012), isto sustenta a ilusória ideia de haver crescimento econômico com desenvolvimento social e ambiental, visando a superação das desigualdades sociais com promoção da equidade através de políticas públicas, como a assistência social. Neste enfoque, percebe-se que as desigualdades sociais persistem e o que muda são as formas de seu enfrentamento, com políticas de inclusão e mínimo sociais, voltados para os segmentos mais pobres.

Mauriel (2012) em sua obra reforça a estreita relação entre o combate à pobreza sob o oferecimento do Estado na promoção de capacidades por meio da Política Nacional de Assistência Social (PNAS/2004). Esta deve atuar com uma rede protetiva de combate à pobreza extrema e prevenir situações de risco e vulnerabilidade social e ainda possibilitar que estes segmentos tenham acesso ao consumo no mercado e outros bens e serviços.

O que se verifica, contudo, é que a tardia institucionalização da Política de Assistência acontece num ambiente onde o tratamento da questão social centrado no combate à pobreza focalizada só fez aprofundar o processo de desconstrução simbólica e ideológica da Seguridade enquanto base para pensar e construir as políticas sociais, dificultando justamente o caráter intersetorial que tal política deveria ter com as demais políticas públicas (MAURIEL, 2012, p. 189).

Isto confere à política de assistência social um novo formato, principalmente com a centralidade nos programas de transferência de renda para o combate à pobreza. A implantação da Política Nacional de Assistência Social demonstra que muitos de seus mecanismos vêm sendo implementados, porém, a autora aponta que houve uma contra partida: a subtração de direitos de parte da classe trabalhadora.

E isso não se faz aleatoriamente. Ora, se consideramos a seguridade social como uma das mediações do processo de reprodução social, como um mecanismo que tem uma base material, fundado em necessidades objetivas, mas que ao transitar na esfera das superestruturas, como instituição social e mecanismo de enfrentamento da desigualdade, adquire um caráter ideológico e político, tal desenho adquire outro significado político (MOTA, 2010, p. 135).

\footnotetext{
30 “Todavia, acreditamos que as políticas de Seguridade Social, nas quais se inclui a de Assistência Social, só podem ser consideradas produto histórico das lutas dos trabalhadores na medida em que respondam a necessidade inspiradas em princípios e valores socializados pelo campo do trabalho e reconhecidos pelo Estado. [...]o campo da Seguridade Social também é um ambiente da intervenção política das classes dominantes, seja como mecanismo de integração social, seja como meio de compatibilizar capitalismo, direitos sociais e democracia. Nestes termos, a Seguridade Social é em tese um campo de disputas, seja por parte do trabalho, seja por parte do capital que continuamente tenta adequála aos seus interesses hegemônicos" (MOTA, MARANHÃO, SITICOVSKY, 2010, P. 181-182).
} 
O tratamento da pobreza a partir dessa política aparece de forma desvinculada aos determinantes estruturais, sem captar as desigualdades como fruto do processo de exploração de uma classe social, que tem sua situação socialmente determinada no sistema capitalista. Seguindo esta ideia, a assistência social constrói uma ação acentuada no indivíduo. Indo mais além, observa-se uma tendência a segmentação da exclusão, classificando entre os pobres aqueles que possuem uma condição ainda mais inferior para serem atendidos pela política de assistência social, levando a um conflito e promoção de estigmas entre os usuários.

A "nova" concepção de Assistência, como a própria PNAS afirma, corrobora com os princípios e conceitos presentes na teoria do desenvolvimento humano como liberdade de Amartya Sen, base que fundamenta os documentos dos organismos multilaterais como Banco Mundial e Programa das Nações Unidas para o Desenvolvimento (PNUD) e Organização Mundial do Comércio (OMC) (MAURIEL, 2012, p. 190).

Aqui entra o papel da burguesia que através do Estado manuseia os direitos para garantir os seus interesses e legitimar-se. As críticas estão na ausência da concepção universal de proteção social e na forma como a assistência abarca aqueles que não estão inseridos no mercado de trabalho ou estão exercendo atividades precarizadas. 0 investimento agora consiste em políticas inovadoras de geração de renda com políticas voltadas para a ampliação das demandas no mercado e ampliação da oferta de trabalho. Estas políticas de ativação do mercado de trabalho são estrategicamente uma forma de combate à pobreza, segundo esses órgãos internacionais ${ }^{31}$.

A partir dos anos 2000, vemos no Brasil a implementação de programas de transferência de renda pautados na lógica compensatória e criteriosa. O programa com mais números de beneficiários e que se mantém até hoje é o Bolsa Família. Este programa vem sendo amplamente elogiado pelo Banco Mundial, que chega a sugerir sua implementação nos países africanos para o enfrentamento da pobreza extrema e das desigualdades sociais, defendendo que "[...] tais programas, além de primar pela modernização dos instrumentos técnicos para refinar a seletividade e manter a focalização nas camadas mais pobres são considerados como capazes de atuar no fomento aos capital humano" (MOTA, AMARAL, PERUZZO, 2012, p. 166).

Arma-se a burguesia de instrumentos para esgarçar a história relação entre trabalho e proteção social, posto que a partir de então a tendência é ampliar as ações compensatórias ou de inserção, antes restritas àqueles impossibilitados de prover o seu sustento e, ao mesmo tempo, impõe novas condicionalidades de acesso aos benefícios sociais e materiais nos casos de afastamento do trabalho por doenças, acidentes, invalidez e desemprego temporário, para não falar da perda do poder aquisitivo das aposentadorias e pensões por velhice, morte, invalidez e tempo de contribuição/idade (MOTA, 2010, p. 137).

Nesta direção, observa-se a centralidade da política de assistência social no enfrentamento da pauperização. Assumindo a posição de política estruturadora. 0 foco no tratamento da questão social no Brasil está pautado nas premissas de organismos financeiros internacionais, com destaque aos programas de transferência de renda no combate à pobreza. Para Sitcovsky (2010), a abertura para as propostas destes organismos financeiros pauta-se na defesa da ausência do Estado no âmbito das políticas sociais e na ampliação da participação da sociedade civil sob o argumento da garantia da democratização. 0 autor afirma ainda que estas instituições defendem a redefinição das ações do Estado e da sociedade civil neste processo.

Esta tendência à transferência da operacionalização da assistência para a sociedade civil, especialmente as associações comunitárias, estão sedimentadas no discurso de ampliação da participação o que minimiza, quando não aniquila,

\footnotetext{
31 "Essa análise acerca dos recursos no âmbito da Seguridade Social não tem a intensão de opor as políticas sociais universais, como saúde e previdência social, e as políticas focalizadas às necessidades de quem dela necessitar, no caso, a assistência social. Não se trata de estabelecer um julgamento moral de condenar a assistência social como responsável pela desestruturação da Seguridade Social. 0 que ocorre é que no projeto neoliberal não há extinção das políticas sociais, mas um conjunto de recomendações que redirecionam a política social para a focalização, privatização e voluntarismo em detrimento de políticas sociais universais, sob justificativa de que direitos sociais universais reforçam as desigualdades sociais e exigem grandes somas de recursos públicos" (TEIXEIRA; NEVES, 2018, p. 153-154).
} 
a possibilidade de formulação e de veiculação de vontades coletivas ligadas a projetos societários das classes subalternas, visto que estas associações são deslocadas para a execução direta de serviços assistenciais (SITCOVSKY, 2010, p. 173-174).

Deslocar as funções para a sociedade civil na execução da política de assistência social, segundo Sitcovsky (2010), leva ao apassivamento da classe trabalhadora e usuária da política de assistência social. 0 autor defende ainda a reforma intelectual e moral deste segmento através do avanço da ideia de atendimento individualizado, perdendo o caráter do combate de classe.

Mota, Maranhã e Sitcovsky (2010, p. 182-183) apontam cinco elementos sobre as tendências atuais da Seguridade Social: a regressão das políticas, voltando-se para medidas compensatórias de combate à pobreza extrema; privatização e mercantilização de serviços; emergência do voluntariado e empresas socialmente responsáveis; surgimento de categorias que impedem a análise crítica da realidade social; a ausência de um debate vinculado entre a política de assistência social e políticas de intervenção sobre o trabalho.

Mota (2010) afirma que a Assistência Social em sua atual fase se afirma como um mito social. Mito por causa da sua condição ideológica e prática "[...] robustecida no plano superestrutural pelo apagamento do lugar que a precarização do trabalho e o aumento da superpopulação relativa tem no processo de reprodução social" (MOTA, 2010, p. 141). 0 enfoque estaria justamente na centralidade da assistência social no combate à pobreza, mas dentro dos moldes ideológicos da classe dominante.

Logo, verifica-se uma conjuntura de acentuação e regressão do SUAS através de três vetores: destituição das forças produtivas, com o aumento do desemprego, da pauperização e da precarização do trabalho; aumento da demanda da política de assistência social. Como estratégias de ação, seguiu-se as premissas de Amartya Sen, com o desenvolvimento de capacidades para superação da vulnerabilidade social. Observase que a precarização do mundo do trabalho atinge também os profissionais da assistência social, que pode vir a comprometer o exercício profissional e os serviços. Por fim, concretiza-se uma mercantilização da política de assistência social a partir dos programas de transferência de renda, assim como uma expropriação da assistência social.

\section{CONCLUSÃO}

O capitalismo sempre está em movimento, ele sempre busca formas de se superar com um único objetivo: aumentar ou, pelo menos, manter suas taxas de lucro. Após a crise de 1970, o cenário mundial começou a mudar: tivemos a introdução do neoliberalismo e ainda a globalização. Porém, concomitante a isso, a pobreza e a desigualdade social crescem desenfreadamente, atingindo a classe trabalhadora que já vivia com a pouca cobertura do Estado que o neoliberalismo exigia, o que pode simbolizar uma ameaça ao capital, caso ocorra uma revolta dos trabalhadores.

Preocupados com isto, os capitalistas passaram a recorrer ao Estado para criar medidas de combate à pobreza, embasados no ideário social-liberal. No Brasil, vemos que esta ideologia ganha força a partir dos anos 2000, pensando o papel estratégico que o país possuía diante do capitalismo mundial e no seu posto de país de economia periférica. Os pensadores sociais-liberais destacam estratégias a serem implementadas em nível mundial para trabalhar em torno dos efeitos que se perpetuavam desde a crise, mais especificamente, que levaram ao agravamento da pobreza que assola a classe trabalhadora.

Neste contexto, vemos que as economias periféricas cada vez mais exploram seus trabalhadores com uma força de trabalho de baixo custo e precarizada, o que agrava a situação de pobreza deste segmento no Brasil. Para isto, o Estado brasileiro elegeu a política de assistência social para administrar as desigualdades sociais e focar no combate da pobreza extrema, seguindo as orientações das agência internacionais, como o Banco Mundial.

Percebe-se que no Brasil as políticas sociais estão sendo pensadas na esfera da redistribuição, de acordo com a necessidade da reprodução da classe trabalhadora, para manter a acumulação capitalista. Investiuse, então, em programas de transferência de renda para criar formas de consumo e, assim, movimentar o mercado. Verifica-se que a política de assistência social não possui condições de alterar determinantes estruturais do capitalismo como as expressões da questão social, pois, foi pensada para que atendesse ao pauperismo e não o superar, sendo utilizada como um manejo da pobreza pelo capital, por intermédio do Estado. 
Assim sendo, é evidente que não se erradica a desigualdade social e pobreza enquanto o sistema capitalista estiver em vigência. Diante desta afirmação, constata-se que a política de assistência social tem a funcionalidade de ocultar a Lei Geral da Acumulação Capitalista. Neste cenário, a assistência social assume algumas tendências: a do empreendedorismo social, sob a ótica ideológica de Amartya Sen; ideológicas, impostas pelos órgãos internacionais, que alienam os usuários da política de assistência social; a mudança no perfil dos usuários com o aumento do desemprego e a precarização do trabalho, os quais requisitam a assistência social também como complemento de sua renda, mesmo com o incentivo ao empreendedorismo.

Portanto, através desse breve estudo, entende-se que para refletir sobre as configurações atuais das políticas sociais, em destaque a de assistência, é necessário estar apoiada/o no plano da totalidade, ou seja, observar as tendências do capitalismo e sua relação com esta política. Compreende-se que o desafio para as categorias profissionais que atuam com a política de assistência social consiste em entender os determinantes da lógica capitalista, para assim compreender o movimento em torno das demandas dos usuário e construir meios para idealizar ou solidificar uma base de luta para a classe trabalhadora.

\section{REFERÊNCIAS}

[1] Braga, Ruy. Fundamentando a crise da globalização. In: Braga, Ruy. A rebeldia do precariado: trabalho e neoliberalismo no Sul global. 1. Ed. São Paulo: Boitempo, 2017. p. 22-38.

[2] Branco, Rodrigo Castelo. A “questão social” e o social-liberalismo brasileiro: contribuição à crítica da noção do desenvolvimento econômico com equidade. Revista Emancipação, Ponta Grossa, 8(1): 21-35, 2008. Disponível em: $<$ http://www.uepg.br/emancipacao>.

[3] Castelo, Branco. O social-liberalismo brasileiro e a miséria ideológica da economia do bem-estar. In: Mota. Ana Elizabete (Org.). Desenvolvimentismo e construção de hegemonia: crescimento econômico e reprodução da desigualdade. São Paulo: Cortez, 2012. p. 46-77.

[4] Maranhão, Cezar Henrique. Crise do Capitalismo, Recomposição da Superpopulação Relativa e os Programas de Assistência social: uma reflexão crítica sobre as determinações e estratégias de combate à pobreza. $2004.201 \mathrm{f}$. Dissertação (Mestrado em Serviço Social) - Centro de Ciências Sociais Aplicada, Universidade Federal de Pernambuco, Recife/PE.

[5] Maranhão, Cézar Henrique. Desenvolvimento social como liberdade de mercado: Amartya Sem e a renovação das promessas liberais. In: Mota. Ana Elizabete (Org.). Desenvolvimentismo e construção de hegemonia: crescimento econômico e reprodução da desigualdade. São Paulo: Cortez, 2012. p. 78-105.

[6] Martin, Hans-Peter. A sociedade 20 por 80: dirigentes mundiais rumo a uma nova civilização. In: Martin, Hans-Peter. A armadilha da globalização. Tradução Waldtraut U. E. Rose e Clara C. W. Sackiewicz. São Paulo: Globo, 1997. p. 7-22.

[7] Mauriel, Ana Paula Ornellas. Pobreza, seguridade e assistência social: desafios da política social brasileira. In: Mota. Ana Elizabete (Org.). Desenvolvimentismo e construção de hegemonia: crescimento econômico e reprodução da desigualdade. São Paulo: Cortez, 2012. p. 179-195.

[8] Mota, Ana Elizabete. A centralidade da Assistência Social na Seguridade Social brasileira nos anos 2000. In: Mota, Ana Elizabete (Org.). O Mito da assistência social: ensaios sobre Estado, política e sociedade. 4. Ed. São Paulo: Cortez. 2010. p. 133-146.

[9] Mota, Ana Elizabete; Maranhão, Cezar Henrique; Sitcovsky, Marcelo. As tendências da política de Assistência Social, o Suas e a formação profissional. In: Mota, Ana Elizabete (Org.). 0 Mito da assistência social: ensaios sobre Estado, política e sociedade. 4. Ed. São Paulo: Cortez. 2010. p. 180-198.

[10] Mota, Ana Elizabete; Amaral, Ângela Santana do; Peruzzo, Juliane Feix. O novo desenvolvimentismo e as políticas sociais na América Latina. In: Mota. Ana Elizabete (Org.). Desenvolvimentismo e construção de hegemonia: crescimento econômico e reprodução da desigualdade. São Paulo: Cortez, 2012. p. 153-178.

[11] Silveira Júnior, Adilson Aquino. A restauração do capital e o advento do social-liberalismo. In: A assistência social e as ideologias do social-liberalismo: tendências político-pedagógicas para a formação dos trabalhadores do Suas / Adilson Aquino Silveira Júnior, 2016. Tese (Doutorado em Serviço Social) - Universidade Federal de Pernambuco. CCSA, Recife/PE.

[12] Sitcovsky, Marcelo. Particularidades da expansão da Assistência Social no Brasil. In: Mota, Ana Elizabete (Org.). 0 Mito da assistência social: ensaios sobre Estado, política e sociedade. 4. Ed. São Paulo: Cortez. 2010. p. 147 179.

[13] Stiglitz, Joseph E. Promessas não cumpridas. In: Stiglitz, Joseph E. A globalização e seus malefícios. Tradução Bazán Tecnologia e Linguística. São Paulo: Futura, 2002. p. 50-83. 
[14] Teixeira, Sandra Oliveira; Neves, Daniela. Trabalho e Assistência Social no Capitalismo Dependente: uma análise marxista das chamadas políticas "ativas de mercado de trabalho". In: Boschetti, Ivanete; Behring, Elaine; Lima, Rita de Lourdes de. Marxismo, política social e direitos. São Paulo: Cortez, 2018. p. 133-163.

[15] Yazbek, Maria Carmelita. Políticas Sociais e Assistenciais: estratégias contraditórias de gestão estatal da pobreza das classes subalternas. In: Classes subalternas e assistência social. 9. ed. ver. rev. e ampl. São Paulo: Cortez, 2016. p. 49-77. 


\section{Capitulo 9}

Globalização e os impactos sobre as experiências migratórias dos haitianos no Oeste do Paraná

\section{Claudimara Cassoli Bortoloto}

Resumo: Esse artigo aborda a discussão sobre o processo migratório de haitianos para o Oeste do Paraná. A amostra delineou estudos referentes a imigração no município de Cascavel dado pela atração de mão de obra para a realização de trabalhos manuais voltados majoritariamente para a construção civil e frigoríficos. 0 processo migratório é discutido a partir de fenômenos que são considerados impulsionadores como a globalização, as transformações no mundo do trabalho e o rompimento de fronteiras. Buscou-se nas fontes secundárias como jornais e revistas traçar o percurso, bem como experiências e trajetórias desses imigrantes. 0 deslocamento de pessoas entre países periféricos perfaz as diásporas migratórias contemporâneas. Como resultado desse trabalho constata-se as transformações no mundo do trabalho e seus efeitos sobre as migrações atuais, as demandas dos imigrantes frente ao Estado Nação que por sua vez as responde pautado no pressuposto da igualdade social, sendo essa característica das democracias liberais. Destaca-se o hibridismo cultural e sua imposição sobre os desdobramentos da imigração com ênfase nas fronteiras e a formação de identidades dialógicas, bem como o reconhecimento de direitos desses imigrantes quando passam a perceber na sua organização um potencial para impô-las perante o Estado Nação.

Palavras-chave: imigração, haitianos, globalização,trabalho. 


\section{INTRODUÇÃO}

Esse artigo aborda a discussão entre globalização e seus impactos para a imigração de haitianos no Oeste do Paraná. Através da análise de fontes secundárias como matérias de jornais que tratam sobre os haitianos no Brasil e nessa região delineia as experiências e trajetórias desses imigrantes, compreendendo-as como um fenômeno também relacionado e impulsionado pelas relações econômicas e demandas de trabalhadores pela economia mundial.

A globalização foi uma estratégia ou dinâmica necessária para a expansão do capitalismo e enfrentamento da crise desencadeada sobretudo nos anos 1970. A transnacionalização da economia soou como meio de superação da crise que por sua vez demandou a organização de um sistema estatal compatível com as demandas da economia global, havendo assim a desregulamentação do estado ou o neoliberalismo.

O peso do estado mínimo foi sentido na redução de direitos, precarização dos serviços públicos, flexibilização das relações de trabalho, o que impactou diretamente nas políticas migratórias.

0 controle sobre as fronteiras e imigrantes passou a ser parte fundamental das agendas governamentais, nesse contexto, esse artigo visa compreender a dinâmica da imigração de haitianos para o Brasil, pautado, sobretudo na dinamização da economia e demanda por força de trabalho, impulsionada como a globalização que permite a transnacionalização da economia, ao passo que desencadeia também o fluxo e a mobilidade de trabalhadores.

A globalização se desdobra em vários mecanismos que lhe são partes, como o crescimento da desigualdade social, as relações de domínio ou geopolíticas entre os países, o laços familiares, as imagens que projetam sonhos e outras formas de viver.

Destaca-se que a imigração e sua importância segue a lógica da dinâmica das relações de trabalho, o fechamento e abertura de fluxos conforme a demanda do capital, e ações de fechamento de fronteiras quando os fluxos migratórios são considerados desnecessários. Ganha centralidade os efeitos do neoliberalismo, perda de autonomia do Estado frente às políticas migratórias, quais tem sido limitadas ao controle dos indivíduos e das fronteiras, por outro lado, ganham força as instituições e cortes internacionais nos Estados Unidos e na Europa, que ora são considerados como substitutos do papel do Estado no que concerne as políticas de reconhecimento, ora são considerados impulsionadores da autonomia Estatal, pois intensificam sobre ele a demanda por políticas de reconhecimento.

\section{IMIGRAÇ̃̃ES E FLUXOS DE MOBILIDADE URBANA NO CONTEXTO DA GLOBALIZAÇÃO.}

A imigração não é um problema recente, embora atualmente tenha sido tratada como um novo fenômeno social, haja visto o destaque que se dá ao imigrante e ao fechamento das fronteiras, percebe-se que de novo existe apenas a implementação de alguns meios estratégicos para o controle dos fluxos e das fronteiras, o que faz dela um velho fenômeno que sempre requer atualizados mecanismos de violência e controle.

Nesse sentido, Sassen (2013) estudou a imigração na Europa e ressaltou a importância das migrações laborais internacionais e inter-regionais como um componente estratégico para a urbanização e industrialização daquele continente. Ressaltou a intima relação entre as migrações de pessoas para a Europa e o desenvolvimento da estrutura urbana, sendo as regiões de rápido crescimento e destino majoritário dos imigrantes.

Sassen (2013) revela ser a Europa um país de imigrantes, e portanto um continente marcado pela imigração. Não há como escrever sobre migração e os fluxos de refugiados sem se remeter a muitos temas relacionados como a urbanização, demografia, industrialização, guerra e a política. A imigração possui fluxos variados, mas limitados no espaço, tempo e escala, não pode ser explicada como simples consequências de causas externas, exógenas como se faz na atualidade. Sua dinâmica prescindi explicações que vão para além daquelas que centram-se no deslocamento dos sujeitos como simples estratégias e melhoria de suas condições de vida quando comparadas as do países de origem. Essa é a retórica dos países que são rotas de fluxos migratórios, atribuem aos imigrantes a culpa pelo deslocamento, o que os tornam responsáveis pelo aumento da pobreza e desigualdades quando simultaneamente fecham suas fronteiras como estratégia para impedir e conter os fluxos de imigrantes (SASSEN, 2013).

Contudo, quando compreende-se a imigração relacionada ao desenvolvimento do sistema econômico, que pode fomentá-la ou restringi-la conforme períodos de crescimento ou crises, se tem outra compreensão do fenômeno, ao passo que ele torna-se uma questão de enfrentamentos, cujas soluções vão muito além do 
simples fechamento das fronteiras.

Assim, conforme Sassen (2013) o país receptor não pode restringir sua ação como um mero observador passivo, com políticas direcionadas ao controle de fronteiras, mas deve, desenvolver políticas que busquem a acolhida, integração, e simultaneamente abandonar de uma vez por todas o discurso alarmista pautado na discriminação e ódio.

A presença dos trabalhadores estrangeiros é uma necessidade do sistema econômico, e um fator de desenvolvimento, e os fluxos de imigrantes estão historicamente pautados na necessidade da economia nacional (SASSEN, 2007).

Com esse propósito, visa-se discutir o contexto que impulsionou as migrações de haitianos para o Brasil, com ênfase na Região Oeste do Paraná, apresentado sob o ponto de vista das fontes secundárias como notícias divulgadas pela imprensa escrita que aborda a questão para, posteriormente pensar a imigração atrelada a industrialização e urbanização, sendo ela promotora do desenvolvimento econômico.

o período de estudo dessa pesquisa tem como marco inicial o ano de 2010, dado ao abalo do Haiti por um terremoto de grandes proporções, que assolou e precarizou ainda mais as condições de vida da população, fazendo da imigração uma estratégia para a superação da degradação e condições de vida.

O Haiti foi devastado por um terremoto em janeiro de 2010, deixando centenas de milhares de mortos e mais de 3 milhões de pessoas desabrigadas. A economia do país já estava devastada pela instabilidade política, que motivou, inclusive, a intervenção da ONU. Nesse cenário, a imigração foi o caminho encontrado por milhares de haitianos. E uma alternativa foi a busca de oportunidades no Brasil. Os primeiros imigrantes chegaram ao país ainda em 2010, geralmente em situação de grande vulnerabilidade social e sanitária (BRASIL, 2012, p. 01).

Não só a imprensa oficial, mas outros meios de comunicação vinculam o ano de 2010 como o período que abre as imigrações massivas de haitianos para o Brasil, o que pode ser visto em:(CAMARGO, 2012; LUDWIG, 2013; PRAZERES, 2012; PUFF, 2012; ROSSI, 2012;WALTER, 2012; SILVA, 2013).

De acordo com Marianna Camargo (2013), a rota migratória dos haitianos compreende dois destinos fronteiriços, sendo um deles a cidade de Brasiléia no Acre, localizada entre a fronteira Brasil e Bolívia, cujo trajeto incorpora República Dominicana, Equador, Panamá, Peru e Brasil. Camargo (2013) ressalta os obstáculos da imigração e as dificuldades desses imigrantes dede a saída do Haiti, chegada e permanência no Brasil. A tensão e o mercado negro da migração são relatados em depoimentos divulgados por vários jornais que tratam da questão.

Essas dificuldades não cessam em solo brasileiro, a maioria chega em condições irregulares vivenciam uma verdadeira saga até alcançarem a legalização para permanecerem no país.

$\mathrm{O}$ agravamento das condições econômicas pode ser caracterizado como um dos fatores que impulsionou a imigração, pois o terremoto de 2010, deixou mais de 300 mil mortos e milhares de feridos. Esse acontecimento intensificou a necessidade dos haitianos venderem sua mão de obra em outro país, o que convergiu com a demanda brasileira por mão de obra.

Sassen (2014) examinou a atual desigualdade crescente no mundo, alertando que o seu crescimento pode continuar expandir determinados tipos de expulsões. Para os pobres, isso significa a expulsão de seus espaços de vida, enquanto os ricos sentem-se isentos de qualquer responsabilidade em relação as remoções.

A concentração de renda associada ao crescimento da desigualdade social foi um fator que impulsionou o deslocamento de pessoas, Sassen (2014) exemplifica casos concretos como Grécia e Espanha, bem como outras regiões, quando diferentes formas de expulsão se difundem em particulares áreas do mundo. Um crescimento que em duas décadas causou o deslocamento da população, principalmente no sul para o norte dos Estados Unidos.

Assim, Sassen (2014) revela a mobilidade humana como uma possibilidade de futuro de muitos que encontram-se com condições de vida deterioradas, cuja maioria nunca vai voltar para casa, ao passo que faz de novos locais ou fronteiras verdadeiras zonas de guerra, como áreas de plantações, minerações, dentre outros. 
Embora seja considerado crime o encarceramento de pessoas, o lucro e o tratamento dessas como meras mercadorias é uma prática comum, sendo essa uma das principais estratégias da rota imigratória entre o Haiti e o Brasil, conforme explicita a reportagem abaixo:

Mas a Polícia Federal já mapeou que não se trata apenas de uma migração espontânea. Os haitianos são trazidos para o Brasil por uma máfia de facilitadores (os "coiotes"), que cobram caro por isso. Nessa rota, os imigrantes haitianos seguem de avião do Haiti até o Equador, onde não precisam de visto, e atravessam de ônibus o Peru, por onde chegam ao Brasil. A viagem chega a levar três meses (BRASIL, 2012, p.01).

Um dos principais destinos desses imigrantes é a cidade de São Paulo, no entanto, outras regiões também são alocadoras de mão de obra, é nesse contexto que iniciou-se a imigração para o Oeste do Paraná, onde empresários iam até Brasiléia para agenciar a mão de obra de trabalhadores imigrantes em situação legal.

o Paraná recebeu nos últimos dias dezenas de haitianos que se arriscaram na imigração para o Brasil em busca de oportunidades. Os estrangeiros, que entraram ilegais no país, tiveram a documentação legalizada pelo governo e vão trabalhar em empresas que enfrentam carência de mão de obra e se sensibilizaram com a situação deles. Ontem, 44 haitianos desembarcaram em Cascavel, onde vão trabalhar nas obras do Hospital São Lucas, que pertence à Faculdade Assis Gurgacz (FAG). Eles também vão construir um novo bloco na faculdade. "Há seis meses nós procuramos mão de obra e não conseguimos suprir toda a necessidade. Mas o que pesou muito também foi a questão social", explica o engenheiro responsável pelas obras, Carlos Oya. 0 contato com os estrangeiros foi intermediado pela Secretaria de Justiça e Segurança Pública do Acre. 0 estado é a principal porta de entrada dos haitianos no Brasil (GONÇALVES, 2012, pg 01).

Além da degradação das condições de vida, outro fator que pode ter impulsionado a imigração haitiana para o Brasil associa-se a razões geopolíticas, ou, como define Sassen (2010, p.117), tem a ver com "laços político-econômicos anteriores" estabelecidos entre os dois países, formados pela liderança da tropa militar brasileira na Missão de Estabilização das Nações Unidas no Haiti (MINUSTAH). Essas tropas estão desde 2004 no país e tem a função de deter os crescentes índices de violência causados por questões políticas e econômicas (OLIVEIRA, CATAI, PEREIRA, 2015).

A globalização desencadeia não só a transnacionalização do capital, mas também a mobilidade humana, nesse sentido, os imigrantes que se deslocam para outros países atraem outros membros familiares para junto de si.

Os anseios em trazer a família para o Brasil são relatados em muitas matérias de jornais, os quais não se restringem a região Oeste do Paraná, mas consistem em um desejo comum entre os migrantes.

Com o dólar batendo quase $\mathrm{R} \$ 3$, fica difícil mandar dinheiro para casa, onde estão meus pais, minha esposa e minha filha. Meu objetivo é trazê-los para cá, mas o salário é pouco", disse Nauhm Saint-Julien, que no início trabalhou em um frigorífico, mas depois foi contratado como auxiliar em um estúdio de fotografia (PLATONOW, 2015, p. 01).

Os desempenho do trabalho manual e dos baixos salários, obrigam esses trabalhadores a estenderem suas jornadas de trabalho ou submeterem-se as triplas jornadas como um meio de juntar pecúlio para viabilizar a vinda de outros membros familiares, garantirem a manutenção daqueles que permanecem em seus países de origem como evidencia o relato de um haitiano a reportagem de Prazeres (2012, p 01) "Quanto mais rápido a gente começar a trabalhar, mais rápido vamos mandar dinheiro para os nossos filhos e trazê-los pra cá", explicou Lysnie."

Além das relações familiares que são um impulsionador das imigrações no contexto da globalização, Apaddurai (2004) mencionou a relação de imprevisibilidade entre acontecimentos mediatizados e audiência migratória que caracterizam a vida moderna, como o que a define ou marca a relação entre globalização e o moderno.

Para Appadurai (2004) as diferentes diásporas, sejam as migrações de pessoas de um país para outro, ou dos refugiados que são obrigados a se deslocarem, carregam consigo a imaginação e força para transformar vidas cotidianas em novos projetos sociais. 
As novas formas de produções de imagens que chegam aos migrantes, sejam por textos, narrativas e os modelos, através dos meios de comunicação de massa, marcam e separam as migrações contemporâneas das migrações do passado.

E depois há os que se deslocam em busca de trabalho, riqueza e oportunidades, muitas vezes porque as circunstâncias em que encontram são intoleráveis. Transformando e alargando ligeiramente de termos importantes de Albert Hirschman, lealdade e saída, podemos falar de diásporas de esperança, diásporas de terror e diásporas de desespero. (APPADURAI, 2004 p. 17).

Não só o contexto familiar, mas a inserção das imagens projetadas por ferramentas tecnológicas como celulares e computadores através da internet são também impulsionadores das imigrações contemporâneas ou da era global. São significativas as contribuições de pensadores vinculados a teoria pós-colonialista que ressaltam a globalização impulsionada pelas imagens e referências de outros países, lugares e territórios, que podem constituir-se em experiências de vida.

Nessa mesma perspectiva, Todorov (2011) ao analisar o elemento familiar como um impulsionador da imigração destacou a importância da família e do trabalho dos imigrantes para garantir as mínimas condições de sobrevivência daqueles que permaneceram em seus países de origem conforme o autor:

Las personas que empreenden esta aventura no sólo buscan trabajo, sino que tambíen se juegan su honor, ya que se vem obligados a encontrar el modo de alimentar a sus padres, a sucónyuge o a sus hijos, que siguen em el país de origen (TODOROV, 2011, p. 19).

Corroborando com Todorov (2011), Ulrich Beck (2007) enfatiza que a globalização impõem não só a transnacionalização do capital, mas também a mobilidade de pessoas, que por sua vez demanda a necessidade de pensar socialmente uma perspectiva cosmopolita. Calcada na expansão de biografias transnacionais, o mundo contemporâneo se depara com a migração ampliada:

[...] hay cada vez más grupos que no vienen en un país o em outro sino en varios países a la vez. En certo modo esas personas desempeñan una función de puente. Al estabelecer redes, organizaciones o instituciones de carácter transnacional y visitar regularmente a los familiares de lavieja pátria crean numerosos vínculos entre el país de origen y la sociedade de adopción, contribuyendo al mismo tempo a la exportación de modos de vida, normas y pretensiones occidentales: <<the West and the rest>> se encuentran el uno con el outro (BECK, U. E, 2007, p. 26).

Além desse aspecto, Sassen (2014) ressalta que as imigrações geram também o armazenamento de pessoas formais e informais ou o que ela denomina de campos de concentração, o que facilita também a exploração e sujeição desses indivíduos a condições degradantes de trabalho, como ocorre em minoritários grupos de países ricos que armazenam esses imigrantes em prisões. Robustos homens e mulheres desempregados são armazenados em guetos ou favelas e vivem em condições sub-humanas (SASSEN, 2014).

Nesse sentido, são visíveis as precárias condições desses imigrantes no Brasil, que conforme DCM (2014, p. 01):

O abrigo na pequena cidade no Acre, próximo à fronteira com a Bolívia e o Peru, foi fechado em abril. Centenas de imigrantes viviam no local em situação degradante, com esgoto a céu aberto. Com o fechamento do abrigo e o fim das cheias que isolaram o estado no início do ano, o fluxo migratório se intensificou. De acordo com o governo do Acre, dos 2.500 haitianos que viviam em Brasileia, 2.300 receberam ajuda para deixar o estado.

Além de condições degradantes de trabalho muitos imigrantes se deparam com o preconceito e xenofobia, a esse exemplo são relatadas situações como dificuldades mínimas de sobrevivência como a de conseguir casas para alugar ou a permanência em locais já alugados para moradia, "Ele disse pra gente ir embora porque não está conseguindo vender apartamentos porque os compradores não querem morar no mesmo lugar onde vivem haitianos", disse Samuel Emilcar, um dos estrangeiros que diz estar sendo vítima de racismo. (HAAB,2014, p. 01). 
Para além de manchetes nacionais, o preconceito se reproduz no âmbito nacional, conforme nos evidencia uma matéria de maior abrangência.

"Se você quer, pega. Se não quer, não quer". Foi assim que Alix Mustivas, de 26 anos, foi tratado pelo patrão após se machucar enquanto trabalhava na construção civil. Após fraturar a coluna o braço em dois lugares durante o trabalho - sem carteira assinada - o dono da empresa ofereceu $\mathrm{R} \$ 300$ ao jovem. "Eu disse que minha vida não valia $R \$ 300$ "(PRAGMATISMO, 2016, p. 01)

0 preconceito e a xenofobia são aspectos comuns ocorridos nos diferentes países e tem se intensificado com as políticas de controle, bem como com a centralidade da migração no contexto atual, nessa perspectiva Bortoloto (2019) ressalta alguns episódios que marcam o desprezo e aversão pelo outro, consubstanciando-se em tratamentos desumanizadores. Assim três episódios recentes ocorridos em diferentes partes do mundo num mesmo ano ganham destaque da imprensa mundial como a separação de crianças mexicanas e seus responsáveis quando flagradas em processo migratório na fronteira do México com os EUA, a recusa da Itália em deixar o navio Aquarius atracar com mais de 600 de imigrantes desidratados e famintos resgatados no mediterrâneo e a expulsão de venezuelanos por Brasileiros xenófobos na Fronteira do Brasil com a Venezuela (BORTOLOTO, 2019). Essas situações tem em comum o preconceito, a xenofobia, a violação dos direitos humanos e a criminalização da imigração, embora tenham ocorrido em diferentes partes do mundo no ano de 2018.

Associado ao preconceito, a desregulamentação da economia e perda da soberania do Estado principalmente a partir dos anos 1990 intensificaram as imigrações, e com elas as políticas de contenção e fechamento de fronteiras. Imigrantes são comumente flagrados em situações irregulares, o que faz deles mais propícios a vulnerabilidade e exploração, submetidos a situações degradantes de trabalho e deterioração dos salários que legalmente são parcos.

É pouco afirmar que a globalização trouxe consigo uma ressignificação declinante do Estado no que concerne a regulação econômica, pois o Estado é uma instituição estratégica para as mudanças legislativas e inovações necessárias para a economia global. Para Sassen (2007), algumas dessas questões podem parecer distantes das relacionadas as políticas migratórias, no entanto é necessário expandir o terreno analítico dentro do qual examinamos as opções das políticas imigratórias em países altamente desenvolvidos. Um exemplo é o deslocamento da função estatal e a implementação de políticas pelas Cortes Internacionais como as instituições transnacionais na União Europeia, o forte incremento na extensão do conteúdo da Comissão Binacional de Imigração Estados Unidos - México, e o rápido aumento de uso dos direitos humanos internacionais por juízes que determinam causas que envolvem a imigração e refugiados.

Para Sassen (2007) há tanto na Europa como nos EUA, a formação de um regime privado para a circulação de trabalhadores de serviços, ou dos trabalhadores terceirizados como parte dos acordos de liberalização do comércio e internacionalização da economia, o que faz "Mi argumento es, entonces, que hay más transnacionalismo em la práctica del que veelojo formal"( SASSEN, 2007, p. 38).

A autora analisou duas políticas imigratórias dos atuais países em desenvolvimento: “ (...) la frontera y el indivíduo como sitios de observancia regulatória”. (SASSEN, 2007, p. 38), bem como estudou as atuais restrições que enfrentam os Estados nos países altamente desenvolvidos para formular as políticas de migração.

Embora haja um conjunto de autores que tratam sobre a diversidade da migração em países desenvolvidos, Sassen (2013) ressalta que é comum entre eles a atribuição do controle do estado sobre suas fronteiras nacionais, ou a convergência em vários aspectos das políticas e práticas migratórias.

Tal esforço regulatório de controle das fronteiras seja dos territórios, terrestres, aeroportos, consulados em países que enviam imigrantes, faz com que o país receptor de imigrantes seja considerado como um agente passivo, tirando deles suas responsabilidades com o processo de imigração, ao passo que a política imigratória está delineada como " (...) una consecuencia de la sancciones individuales de los emigrantes; el pais receptor és considerado un agente pasivo, que no está implicado em el proceso de la emigración ( SASSEN, 2007, p. 39).

As políticas para refugiados são pautadas no controle dos indivíduos e dos fluxos, quais definem a fronteira e o indivíduo como locais de conformidade regulatória. 
Os tratados interestatais como acordos legais e constitucionais limitam a soberania do Estado, exemplos concretos podem ser vistos na convenção de Haya que em 1930 outorgou o direito do estado em conceder a cidadania, e a convenção de Refugiados de 1952 que afirmava o direito de ir como universal ao passo que permaneceu silenciada no que se refere ao direito de ingresso. É sabido que os direitos dos refugiados não são estabelecidos nas leis internacionais, exceto o seu retorno a força, ficando a margem o direito de concessão de asilo, o que garante a descrição do Estado sobre esse tema.

Já em relação ao indivíduo, as políticas imigratórias tende a atribuir a eles as responsabilidades por estar na condição de imigrantes, o que reforça a ação do Estado sobre cada situação individual, garantindo a legalidade do retorno do sujeito à força para seu país de origem.

Em segundo lugar, sobre el tema del individuo como sitio de observancia, se están tornando evidentes dos lógicas operacionales. Uma de ellas - la que está incorporada en la política inmigratoria - coloca la responsabilidad exclusiva del proceso inmigratorio sobre el individuo, y, por lo tanto, lo convierte en el sitio para el ejercicio de la autoridade del Estado ( SASSEN, 2007, p. 40).

Sassen (2007) ressalta que os sistemas coloniais viabilizaram o processo migratório pelo mundo, o que já é suficiente para tirar das costas dos imigrantes o peso pelas responsabilidades sobre seus deslocamentos. Quando um imigrante chega a um país, e clama por seus direitos e por políticas de reconhecimento, ao fazer isso, reivindica a soberania do Estado, que é o espaço dos direitos humanos.

Embora a globalização tenha imposto sobre o Estado condições para o seu desenvolvimento, aponto de diminuir sua ação ou autonomia, há a conquista de direitos pelos imigrantes junto às Cortes Internacionais. Essas são compreendidas como contraditórias ora remetem o enfraquecimento do Estado quando este nega a cidadania a qualquer imigrante não reconhecendo os seus direitos, ora são entendidas como um fortalecedor do Estado que o ajuda a recuperar sua autonomia diminuída pela globalização: "Las cortes también han sustentado regularmente uma combinação de derechos de los inmigrantes residentes que tienen por efecto limitar el poder del gobierno sobre ellos" ( SASSEN, 2007, p. 41).

A autora enfatiza a importância dessas cortes para limitar os governos a restrição ou detenção daqueles que buscam asilos quando entram em um país. Conforme Sassen (2007) há uma importância crucial dessas cortes em recuperar a soberania do Estado perdidos em acordos internacionais, que interpretam ou limitam suas ações em simples reguladores ou controladores de fronteiras.

No Brasil, pode-se pensar isso sob duas formas, a primeira quando reportamos ao papel das instituições não governamentais para pressionar o Estado quanto as políticas de reconhecimento para imigrantes, em segundo ao fazerem isso, assim como as Cortes Internacionais, também reforçam a soberania do Estado.

É visível a importância das Organizações Não Governamentais no Brasil para o acolhimento, bem como sua função de pressionar o Estado e as políticas de reconhecimento.

Desde Brasiléia no início da imigração em 2010 órgãos ligados principalmente a igreja católica ofereciam abrigo para acolhimento dos imigrantes com capacidade inicial para atender 200 pessoas, no entanto esse abrigo chegou a ser ocupado por 800 haitianos, sendo fechado em 2014, devido a superlotação para além de sua capacidade.

0 governo do Acre determinou a desativação do abrigo de haitianos em Brasileia, ao sul do estado. 0 antigo abrigo será substituído por um novo, na capital, Rio Branco. Segundo o secretário de Direitos Humanos acreano, Nilson Mourão, o abrigo de Brasileia deverá ser fechado neste final de semana. Para os novos imigrantes que entrarem no Brasil pela fronteira do Acre, a orientação é a de que sigam viagem até Rio Branco para providenciar documentação. Até então, Brasileia e Epitaciolândia eram as cidades que faziam o p rimeiro acolhimento dos estrangeiros (SARRES, 2014, p. 01). 
A sociedade civil, as ONG's e órgãos religiosos, reuniram-se para ajudar na recepção dos haitianos, a fim de tentar dar a eles um lugar com mínimas condições de dignidade. É incontestável o papel dessas instituições no acolhimento desses imigrantes, pois além de pressionar o Estado para as políticas de reconhecimento como documentação por exemplo, as igrejas disseminam junto a seus seguidores valores voltados para a tolerância e respeito a essas pessoas.

A estimativa é que pelo menos 20 mil haitianos tenham passado por Brasileia, aumentando a demanda por serviços. Até agora foram gastos $R \$ 15$ milhões no acolhimento dos haitianos. "Brasileia é uma cidade pequena, que estava tumultuada com a quantidade de imigrantes e lidando com a situação há quatro anos. 0 governo entendeu que a alternativa é enviá -los para Rio Branco. Os imigrantes não vêm para ficar. 0 estado [Acre] é a porta de entrada", informou Mourão. Nos abrigos, os estrangeiros recebem alimentação, documentação, serviço de atenção à saúde e oferta de trabalho por parte de representantes de empresas que visitam o local. Com o fechamento do abrigo, desde a semana passada, 950 estrangeiros deixaram Brasileia rumo a São Paulo e aos estados da região Sul: Paraná, Santa Catarina e Rio Grande do Sul. "Eles [os estrangeiros] sabem para onde vão, têm roteiros, eles não vêm sem ter isso. Há quem fique em São Paulo, muitos outros vão para o sul", disse o secretário de Direitos Humanos do Acre. (SARRES, 2014, p. 01).

No município de Cascavel também é frequente a presença desses órgãos, principalmente no que tange a organização dos haitianos para coletivamente impor ao estado seu direito e políticas de reconhecimento. Dados não oficiais estimam a presença de aproximadamente três mil haitianos em Cascavel (CORAZZA, 2015), onde as vagas de emprego nos principais frigoríficos são também ocupadas por boa parte desses imigrantes, quais passaram também a se organizar em associações.

De acordo com Bortoloto (2019) os dados sobre a quantidade de haitianos em Cascavel são incertos, e variaram em 2018 entre quatro e cinco mil, onde Cascavel passou recentemente a ser a cidade que recebeu o maior número desses imigrantes no Estado do Paraná. Nesse contexto, a presença das igrejas se constituiu como fundamental para a recepção desses imigrantes, que em situação semelhante ao resto do país não conta com políticas migratórias de acolhimento, asilo e integração.

A igreja não pode se furtar de uma de suas principais funções que é compromisso com os direitos humanos. Temos essa preocupação da proteção e do acolhimento dessas pessoas que vem de outros países que vem à Cascavel em busca de um recomeço", ressalta o religioso (LAÍNY, 2014, p. 01).

É pertinente abordar as organizações coletivas de migrantes haitianos no Oeste do Paraná, quais são fundamentais e constituem-se como novos movimentos que impulsionam as democracias liberais para o reconhecimento de políticas que venham privilegiar as diferenças:

Uma assembleia realizada no último domingo reuniu cerca de 80 haitianos em Cascavel, no Oeste do Paraná. 0 objetivo foi discutir a criação de uma associação para tratar dos interesses dos 1,5 mil haitianos que vivem na cidade. Marcelin Geffrard, um dos líderes dos refugiados, diz que a maior barreira enfrentada é o idioma. Ele conta que muitos haitianos têm formação profissional, mas não podem aplicar seus conhecimentos pela dificuldade com a língua. Sem colocação em suas áreas de atuação, acabam aceitando trabalhos braçais, como em frigoríficos. 0 preconceito é outro drama vivenciado pelos refugiados, que encontram dificuldades até para alugar imóveis (CAMPOS, 2014, p.01).

A presença dessas instituições vinculadas ou não as igrejas é de suma importância para resgatar no Brasil a autonomia do Estado quando pressionado por políticas de reconhecimento. Seja na Europa ou nos EUA, onde as Cortes tem importância sinequanon para as políticas de reconhecimento, ou no Brasil com as ONGs e instituições, há em comum entre elas o fortalecimento da autonomia do Estado através do desempenho de suas ações. Essas instituições amparadas em códigos internacionais de direitos humanos reivindicam do Estado o reconhecimento do ser humano como um cidadão independente de onde ele esteja.

Surge assim a diversidade de novos atores políticos, Sassen (2007) ressalta a importância deles para a 
formulação de políticas imigratórias na Europa Ocidental, América do Norte e Japão, sendo bem superior ao que existiam em décadas anteriores. Esses atores políticos no Brasil, muitas vezes representam os imigrantes, que lutam por seus direitos.

0 encontro deste domingo foi uma iniciativa do vereador Paulo Porto (PCdoB), em conjunto com a Igreja Episcopal Anglicana e a pró-reitoria de Extensão da Universidade Estadual do Oeste do Paraná (Unioeste). Além de aproximar os estrangeiros da população local e lutar pela garantia de direitos, a associação pretende preservar a cultura haitiana (CAMPOS, 2014, p. 01).

A participação das igrejas tem sido destaque no atendimento desde as primeiras levas, além da igreja Anglicana, Bortoloto (2019) destaca a atuação conjunta da Pastoral do Migrante no município, bem como da Cáritas, sendo autarquias vinculadas a igreja católica que também tem desempenhado importante papel para a organização coletiva, encaminhamentos de demandas para o sistema público, bem como para o mercado de trabalho.

As instituições cumprem papel fundamental na pressão que exercem sobre o Estado e o reconhecimento de direitos, seja as Cortes Internacionais na Europa e nos EUA, ou as ONGs no Brasil, embora se deparem com um Estado liberal e minimizado desde os anos 1990, que trata as diferenças a partir do pressuposto da igualdade social, e tende a exercer políticas pautadas no controle das fronteiras e dos fluxos migratórios.

\section{CONCLUSÃO}

O fenômeno da imigração é antigo, os estudos sobre Europa, Estados Unidos nos indicam que a criminalização da migração ou o destaque dado a esse fenômeno na atualidade, é uma mera forma dos Estados jogarem para os indivíduos as responsabilidades por seu deslocamento. Os fluxos migratórios se abrem ou fecham conforme as demandas do capital. Os imigrantes são responsáveis pelo desenvolvimento urbano e industrial dos países, porém quando o sistema os relega são considerados desnecessários e passam a ser objeto de vigilância e controle do Estado. Políticas de controle das fronteiras e dos fluxos migratórios perfazem a forma de como o Estado se depara com o fenômeno. Para além dessas atitudes, o Estado diminuiu as políticas voltadas para o reconhecimento dos imigrantes, sobretudo com o neoliberalismo. Esse contexto de estado mínimo fez com que sobressaísse as Cortes Internacionais bem como instituições que desempenham dupla função, algumas análises vão considerá-las como substitutas da função do Estado, enquanto outras vão dizer que elas ampliam o resgate da autonomia do Estado diminuída com o neoliberalismo e a globalização. Essas instituições apropriam-se dos direitos humanos e clamam do Estado suas responsabilidades para com os cidadãos, ao passo que fortalecem assim a soberania estatal. No Brasil elas se restringem a organizações principalmente religiosas que acolhem e levam para o Estado as demandas dos imigrantes, estimulando o reconhecimento e a cidadania.

Em território brasileiro, esses imigrantes dão continuidade ao fenômeno migratório que é mundial, e decorre de processos como a globalização, que desdobra-se no aumento das desigualdades sociais, imagens e tecnologias, estímulo das famílias, relações geopolíticas dentre outros destacados nesse artigo.

Contudo, pretendeu-se delinear a imigração desses estrangeiros, e dialogar com a especificidade da região Oeste do Paraná, evidenciando a formação da estrutura urbana e sua demanda por mão de obra no contexto da globalização. Essa formação inclui regiões que antes eram consideradas de menor valor econômico ou destaque, fazendo delas novos espaços para o desenvolvimento econômico, qual se dá sobretudo com presença de trabalhadores, com amplo destaque aos imigrantes haitianos.

\section{REFERÊNCIAS}

[1] Appadurai. Arjun. Dimensões culturais da globalização. Lisboa. Teorema, 2004. p.11- 50.

[2] Beck, U. y E. Beck- Gernscheim (2007) Generación Global. Barcelona: Paidós.

[3] Bortoloto Claudimara C. Migração e trabalho na contemporaneidade: os haitianos no Oeste do Paraná. Tese de doutorado apresentada ao Programa de Pós Graduação em Ciências Sociais Unesp de Araraquara. Araraquara, 2019. Disponível em: <https://repositorio.unesp.br/handle/11449/181314> Acesso em 03 de Abr. de 2019.

[4] Oliveira, Ariel; Catai, Heloisa; Pereira, Letícia. Haiti: A Atual Conjuntura da Minustah e o Brasil. Série Conflitos Internacionais.V2,N3, Junho de $2015 . \quad$ Unesp, Marília. Disponível em:<https://www.marilia.unesp.br/Home/Extensao/observatoriodeconflitosinternacionais/v-2-n- 3-haiti-atual- 
conjuntura.pdf> Acesso em 11 de Jan. de 2016.

[5] Sassen, Saskia.Expulsions:Brutalityandcomplexity in the global economia. Cambridge, Massachusetts, London, England, 2014.

[6] ,Inmigrantes y ciudadanos. De lasmigracionesmasivas a la Europa fortaleza. Madrid: Siglo XXI, 2013.

[7] , Los espectros de laglobalización. Buenos Aires, Fondo de Cultura Económica. 2007.

[8] Todorov, Tz. Muros caídos, muros erigidos. Buenos Aires: Katz, 2011.

\section{REFERÊNCIAS DE JORNAIS E REVISTAS:}

[1] Brasil. Em discussão: Revista de audiência pública do Senado Federal. Ano 3, 10 de março de 2012.Disponível em: $\quad<$ http://www.senado.gov.br/noticias/Jornal/emdiscussao/defesa-nacional/sociedade-armadas- $\underline{\text { debate- }}$ militares-defesa-nacional-seguranca/depois-do-terremoto-no-haiti-imigrantes- haitianos-buscam-refugio-no-brasil-erecebem-vistos.aspx > Acesso em 25 de Fev. de 2016.

[2] Campos, Marcela. Haitianos se unem em Associação. Gazeta do Povo. Curitiba, 14 de Abril de 2014. Disponível em: <http://www.gazetadopovo.com.br/vida-e- cidadania/colunistas/entrelinhas/haitianos-se-unem-emassociacao- 9503qbqye49sdf0slklnrp6by> Acesso em 11 de Abr. de 2015.

[3] Gombata, Marsílea. Carta Capital. 01 de Jun. de $2014 . \quad$ Disponível em:<http://www.cartacapital.com.br/internacional/minustah-completa-10-anos-em-meio-a7340.html>Acesso em 26 de Fev. de 2016.

[4] Gonçalves. Juliana. Cascavel se torna a casa de 44 haitianos. Jornal Gazeta do Povo, 31 de jan. de 2012. Disponível em: http://www.gazetadopovo.com.br/vida-e- cidadania/cascavel-se-torna-a-casa-de-44-haitianos7mm89ruwe0f8lbi21dfu730b2> Acesso em 18 de Jan. de 2016.

[5] Haab, Luiz. Haitianos dizem ser vítimas de racismo no Oeste do Paraná. G1: Paraná Oeste e Sudoeste. Publicado em 28 de Fev de 2014. Disponível em: http://g1.globo.com/pr/oeste-sudoeste/noticia/2014/02/haitianosdizem-ser-vitimas-de- racismo-no-oeste-do-parana.html> Acesso em 26 de Fev de 2016.

[6] Laíny, Laís. Encontro reunirá haitianos de Cascavel. CGN/Notícias UOL. 12 de Abreil de 2014. Disponível em $<$ http://cgn.uol.com.br/noticia/87714/encontro-reunira-haitianos-de- cascavel> Acesso em 13 de Jun. de 2015).

[7] Pragmatismo. Haitianos relatam rotinas de humilhações e preconceito no Brasil.

[8] Pragmatismo político. Publicado em 26 de Fev de 2016. Disponível em: <http://www.pragmatismopolitico.com.br/2016/02/haitianos-relatam-rotina-de-humilhacoes- $\quad$ e-preconceito-nobrasil.html> Acesso em 28 de Fev. de 2016.

[9] Prazeres. Leandro. Série de reportagens mostra a busca dos haitianos por uma nova vida no Brasil. Acrítica. Com notícias. Manaus, 22 de Janeiro de 2012. Disponível em: http://acritica.uol.com.br/noticias/Manaus-AmazonasAmazonia-Serie-reportagens-mostra- haitianos-Brasil 0 631736872.html, Acesso em: 22 de Jul. de 2013.

[10] Sarres, Carolina. Governo do Acre fecha abrigo de haitianos em Basiléia. EBC. Publicado em 09 de Abr. de 2014. Disponível em: <http://www.ebc.com.br/noticias/brasil/2014/04/governo-do-acre-fecha-abrigo-de-haitianosem-brasileia> Acesso em 13 de Jan. de 2016.

[11] Zylberkan, Mariana. Sem mão de obra, Santa Catarina importa haitiano. Revista Veja. Publicado em 02 de Fev. de 2014. Disponível em:<http://veja.abril.com.br/noticia/brasil/sem-mao-de-obra-santa-catarina-importahaitianos> Acesso em 13 de Jan. de 2016. 


\section{Capítulo 10}

Juventude rural: Entre o partir e o permanecer no campo. A dinâmica dos jovens rurais do Município de Bela Vista de Goiás (Goiás / Brasil)

\section{Lorrany dos Santos Ferreira}

\section{Andréa Vettorassi}

Resumo: Este estudo se insere no conjunto de reflexões sobre a juventude, em especial, sobre aquela que reside no campo e estuda na cidade. 0 trabalho busca identificar e analisar as concepções de campo e de cidade dos jovens estudantes das escolas públicas do município de Bela Vista de Goiás, região metropolitana de Goiânia/Goiás, que, em meio a tantos dilemas sobre o futuro, ainda precisam optar entre permanecer no campo como integrante da agricultura familiar ou partir para a cidade em busca de outro modo de vida que corresponda às suas aspirações futuras. 0 foco da pesquisa são os estudantes do Ensino Médio, exclusivamente aqueles entre a faixa etária de 15 a 24 anos, da escola Colégio Estadual Pedro Vieira Januário, cuja formação acontece em período integral. Assim, sendo uma escola de período integral, buscamos compreender como esses jovens se relacionam com o campo/rural - cidade/urbano, consequentemente, como sua identidade é construída e o "peso" de sua condição social.

Palavras-chave: Juventude. Campo-cidade. Identidade. 


\section{INTRODUÇÃO}

Pensar em juventude é associá-la a problemas. 0 termo "jovem" refere-se a uma fase entre a infância e a vida adulta, e nesse processo de transição que a identidade do indivíduo é formada. Sposito (2002) reconhece que a própria definição da categoria juventude aponta para um modo de passagem heteronomia da criança para a autonomia de um adulto -, no entanto, a duração e suas características têm variado nos processos e formas, porque a estruturação das idades difere enormemente de uma sociedade a outra. Dessa forma, por ser uma etapa da vida que merece atenção, este estudo reflete sobre a questão de jovens do meio rural, mas jovens esses que dividem sua cultura entre dois espaços: o campo e cidade.

A proposta de trabalho surge de uma aproximação com jovens estudantes do ensino médio da rede estadual de ensino do município de Bela Vista de Goiás, região metropolitana de Goiânia - Goiás (Brasil), denominada Grande Goiânia, que assim como muitos jovens, migram diariamente do campo para a cidade a fim de concluírem o ensino médio. Esses jovens, além da terem preocupações próprias de sua fase, ainda precisam decidir se, após concluírem o ensino básico, devem buscar uma profissionalização (ou não) que os mantêm integrados à agricultura familiar ou se devem romper com a atividade camponesa e migrar para os centros urbanos a fim de mudarem sua realidade, buscando uma profissão que os levem a ascensão social.

Várias questões permeiam essa discussão, portanto, para que seja possível uma investigação sociológica desse evento, propomos compreender, especialmente, as razões do processo de migração entre o campo e a cidade praticada por estes jovens em questão. Para tanto, tomamos como objeto de pesquisa os alunos do Colégio Estadual Pedro Vieira Januário situado no município de Bela Vista de Goiás, em Goiás. 0 foco da pesquisa são os alunos, entre a faixa etária de 15 a 24 anos, que residem no campo, mas que precisam migrar diariamente para a cidade a fim de concluírem o ensino médio.

Além desses pontos levantados, os objetivos da pesquisa se ampliam em compreender o conceito de juventude, especialmente o debate conceitual da categoria em análise, os jovens rurais. Por conseguinte, buscamos compreender o imaginário da juventude rural, sobretudo sobre o futuro e suas perspectivas profissionais; Entender a relação do jovem com o campo e a cidade e, especialmente, a construção de sua identidade (ou identidades).

\section{JUVENTUDE RURAL: DEFINIÇÕES E IDENTIDADES}

As discussões que giram em torno do termo juventude remetem a uma série definições divergentes. Culturalmente determinada, a demarcação desta etapa da vida é sempre imprecisa, sendo referida ao fim dos estudos, ao início da vida profissional, à saída da casa paterna ou à constituição de uma nova família ou, ainda, simplesmente a uma faixa etária (CARNEIRO e CASTRO,2007).

Segundo Zagury (2004) a juventude é considerada como uma fase do desenvolvimento humano que requer direitos e deveres específicos. Para Abramo, Freitas e Sposito (2000), a juventude caracteriza-se por dois períodos: adolescência e juventude propriamente dita. 0 ponto de partida da adolescência iniciase aos 15 anos de idade e estende-se até os 19 anos, aos 20 anos há início de uma nova fase que vai até 24 anos. Dessa forma, entende-se a juventude em função da idade cronológica.

De fato, a delimitação de idade para a definição de juventude apresenta- se deficiente. Abramovay et at. (1998, p. 37) explanam que: "não existe uma definição universalmente aceita para os limites de idade em que se encontra a juventude". Estes autores acreditam que a principal característica desta fase corresponde à naturalização da continuidade do modo de vida dos pais. (ABRAMOVAY, 2000).

Quanto aos jovens rurais, Castro (2009, p.182) aponta que "a juventude rural é percebida como uma população específica, uma minoria da população jovem do país". Apesar de ser minoria, não é um contingente pequeno, a ponto de ser invisibilizado, principalmente nas políticas públicas voltadas para a juventude. Castro (2009) aponta que a categoria de análise juventude rural no Brasil aparece constantemente associada ao problema da migração do campo para a cidade e à atração dos/das jovens pela cidade, desinteressados/as pelo campo. 
Tendo em vista a gama de definições, é necessário sublinhar que o processo de construção da categoria juventude rural está intrinsecamente ligado aos aspectos sociais, econômicos, culturais e políticos que permeiam a sociedade; e que, a partir dos anos de 1980 e 1990, o debate sobre a juventude no Brasil trouxe o olhar da diversidade para além dos cortes etários, ou apesar deles, não se fala mais em juventude, mas em juventudes (NOVAES, 1998). Isso remete para a construção de possibilidades não homogeneizadoras da juventude, seja ela do campo ou da cidade.

No caso particular da juventude do meio rural, os pesquisadores têm encontrado dificuldade na delimitação do que se designa como juventude rural, categoria que se caracteriza pela transitoriedade inerente às fases do processo de desenvolvimento do ciclo vital. Aliam-se a isso as imprecisões que pautam o debate sobre o conceito de rural na sociedade contemporânea, questão que ganha relevo com a intensificação da comunicação entre os universos culturais e sociais do campo e da cidade (CARNEIRO, 2007).

Dessa forma, o debate das dimensões do rural e do urbano não é uma tarefa recente no Brasil, pois desde as primeiras décadas do século XX, questões econômicas, políticas e socioculturais da relação cidadecampo foram debatidas, principalmente por conta do processo de industrialização urbana. Muitos dos estudos dessa época pautaram-se sob o viés dicotômico em que se consideram campo e cidade como realidades distintas, de maneira que a existência de uma excluía a da outra. 0 espaço rural, sempre definido como lugar vinculado à tradição e ao atraso, e o urbano como espaço do desenvolvimento. Essa forma de ver esses distintos espaços levou ideologicamente à criação de estereótipos para o homem, e também aos jovens, do campo. Sendo assim, não há como negar que esses estereótipos influenciaram e ainda influenciam, negativamente, as relações sociais entre a cidade e o campo.

Desse modo, os jovens do campo não podem ser olhados apenas a partir do espaço ao qual pertencem, mas nas suas relações permanentes com o mundo urbano. 0 rural se configura como um espaço singular, mas constituído historicamente a partir de dinâmicas sociais internas e externas. A relação rural-urbano não dilui as fronteiras entre esses dois espaços sociais, dinâmicos e heterogêneos. Portanto, esses jovens não estão isolados no mundo rural.

Nesse contexto, cada indivíduo passa a assumir não apenas uma identidade, mas passa a ter duas ou mais, as quais variam de acordo com o momento ou situação vivida, bem como o ambiente e o contexto social, político, econômico e cultural pelo qual passa o homem e a sociedade. Nesse sentido, Stuart Hall coloca que,

as velhas identidades, que por tanto tempo estabilizaram o mundo social, estão em declínio, fazendo surgir novas identidades e fragmentando o indivíduo moderno, até aqui visto como sujeito unificado" (HALL, 1999, p.7).

Isso ocorre com todos os indivíduos, sendo que nisso estão incluídos os jovens rurais. Eles vivem diante de um confronto de ideias e valores; quando em contato com o mundo rural, o jovem possui uma forma de pensar e agir, mas quando em contato com o mundo urbano, possui outras ideias e conceitos. Cada vez maiores são as opções criadas para eles; diferentes formas de lazer, abertura do mercado de trabalho, maior participação política, entre outros. Assim como os demais indivíduos, esses jovens também são afetados pelas transformações do mundo. Estas transformações incluem a modernização da agricultura, como consequência do advento do capitalismo e da industrialização do campo, que acarretou no surgimento de novas tecnologias; Isso fez com que pequenas propriedades rurais tivessem que se adaptar a tais mudanças para não ficarem estagnadas na produção agrícola. Essas transformações na sociedade agrária do século XX são percebidas até hoje, sendo que uma das maiores consequências é visível cada vez mais: a questão do jovem rural, o qual foi inserido nesse processo de mudança.

Nesse sentido, Stuart Hall (1999), traz contribuições quando apresenta três concepções de identidade; a primeira considera a existência do Sujeito Iluminista, fruto dos movimentos como a Reforma Protestante, o Humanismo Renascentista e o Iluminismo, estava baseado em uma concepção de pessoa humana como um indivíduo totalmente centrado, dotado de capacidades de razão de consciência e ação, onde o "centro" consistia em um núcleo interior que emergia quando o sujeito nascia e com ele se desenvolvia. 
Em outras palavras, o centro essencial do eu era a identidade do individuo; a segunda que concebe o Sujeito Sociológico, que remete ao final do século XIX com o desenvolvimento das ciências sociais, particularmente a sociologia, refere-se a crescente complexidade do mundo moderno e a consciência de que este núcleo interior do sujeito não era autônomo, mas era formando na relação com outras pessoas que mediavam para o sujeito valores, sentidos e símbolos - a própria cultura - dos mundos. Entretanto, nessa concepção a identidade preenche o espaço entre o "interior" e o "exterior". O fato é que o sujeito projeta a si próprio nessas identidades culturais ao mesmo tempo em que internaliza seus significados e valores; a terceira delas é a que considera a existência do "Sujeito Pós-Moderno", o qual não tem identidade fixa, essencial ou permanente; o sujeito é fragmentado e possui várias identidades contraditórias ou não resolvidas, o que implica dizer que o sujeito assume identidades diferentes em momentos diferentes.

Portanto, dessa forma que se traz a ideia de Hall ao encontro da questão dos jovens rurais; acredita-se que eles também podem ser considerados "Sujeitos Pós-Modernos", no momento em que não possuem mais uma identidade fixa, sendo que assumem diferentes identidades, por exemplo, quando estão na zona rural ou quando estão na zona urbana. Dessa forma, na medida em que ocorrem mudanças também na zona rural, onde os sistemas de significação e representação cultural se multiplicam, o jovem rural é colocado diante de muitas identidades, as quais podem assumir e ser, dessa forma, um indivíduo não só centrado em seu "eu" interior, nem só formado pela relação com outras identidades; é, no entanto, uma mistura de identidades, sendo que em certos momentos, o jovem privilegia uma delas e em outros momentos, privilegia as outras identidades que possui (PREDIGER, 2009).

Esse contato com diferentes realidades faz com que o jovem rural construa a representação social de si. Esta é entendida por Frossard como sendo o "conjunto de informações, imagens, símbolos, definições, ideias, crenças, saberes, concepções culturais que surgem das interelações coletivas do ser em um dado contexto social" (FROSSARD, 2003, p. 42). Pensa-se que estas relações, a partir das quais o indivíduo constrói sua representação social, também interferem na construção de suas identidades, como aponta Frossard quando afirma que "a representação social interfere na construção ou formação das identidades sociais individuais" (FROSSARD, 2003, p. 42).

Acredita-se, portanto, que o jovem rural, a partir do contato que mantém com diferentes realidades (rural e urbana) e grupos sociais (Igreja, comunidade, escola, entre outros), constrói sua representação social e esta interfere na formação de sua identidade, ou de suas diferentes identidades.

\subsection{MUNICÍPIO DE BELA VISTA DE GOIÁS, AS ESCOLAS ESTADUAIS DE NÍVEL MÉDIO E OS SUJEITOS DA PESQUISA: BREVES APONTAMENTOS}

O município de Bela Vista de Goiás está a $45 \mathrm{~km}$ da capital do estado de Goiás, a cidade de Goiânia. Entretanto, é considerado parte da região metropolitana de Goiânia, conhecida popularmente por Grande Goiânia, uma conurbação de cidades ao redor de Goiânia composta por vinte municípios. A cidade de Bela Vista de Goiás está situada na região centro-oeste do país, sua população é de, aproximadamente, 28077 habitantes (IBGE, 2016). 0 município foi fundando em 1896. Segundo a narrativa local, a cidade surgiu próxima aos centros de mineração, onde tropeiros e carreiros que transportavam mercadorias do estado de Minas Gerais para a estado de Goiás, fizeram do local ponto de pouso e de "rancho dos tropeiros", assim circundando-o surgiu o povoado que, tempos depois, em 5 de junho de 1896, foi elevado à categoria de cidade. 


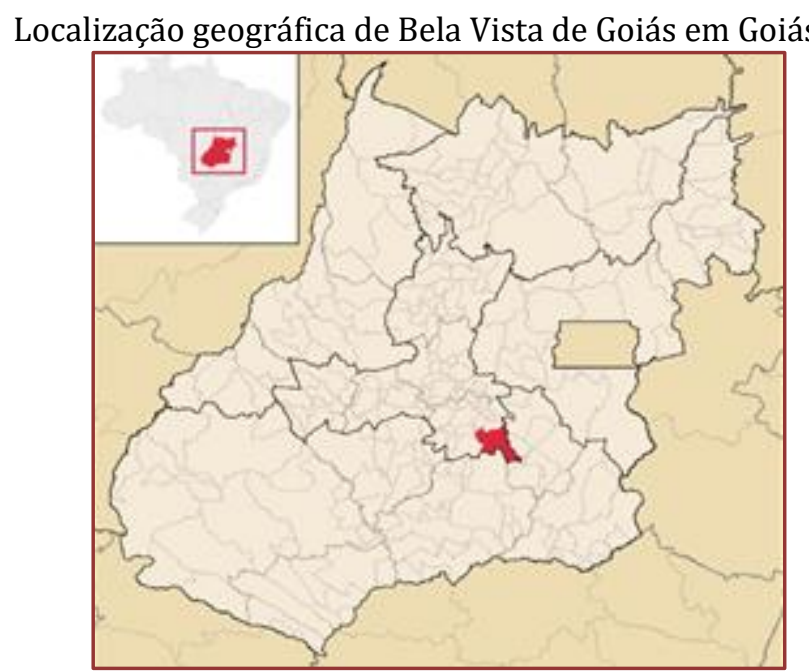

(Foto: Raphael Lorenzeto de Abreu)

A base econômica de Bela vista de Goiás sempre foi alicerçada pelas atividades agropecuárias. Durante muito tempo, a atividade de destaque foi o fumo cultivado e processado no município que foi principal produto de exportação durante décadas. Entretanto, atualmente uma grande quantidade dos proprietários de terra vivem das atividades agrícolas e pastoris. No município há também uma grande criação de gado leiteiro e gado de corte que vem atribuindo um relevante desenvolvimento na cidade.

0 município em questão possui duas escolas públicas que oferecem o ensino médio para os alunos que moram na cidade e para os alunos que moram no campo: a Escola Estadual Dr. Belém e o Colégio Estadual Pedro Vieira Januário. A primeira oferta o 9o Ano do ensino fundamental no turno vespertino; o Programa de Fortalecimento do Ensino Noturno - PROFEN -, no turno noturno; e o ensino médio (1ํㅡㅅㅡo, $2^{\circ}$ Ano e 3 Ano) em três turnos: matutino, vespertino e noturno. A segunda escola, o Colégio Estadual Pedro Vieira Januário, oferta apenas o ensino médio ( $1^{\circ}$ Ano, $2^{\circ}$ Ano e $3^{\circ}$ Ano) em tempo integral, período diurno. A Escola Estadual Dr. Belém no respectivo ano de 2017, no segundo semestre, contava com um total de 494 alunos matriculados no ensino médio distribuídos nos três turnos, 153 alunos matriculados no ensino fundamental e 47 matriculados no PROFEN. 0 Colégio Estadual Pedro Vieira Januário, nesse mesmo período, contava com um total 165 alunos que cursam o ensino médio em período integral.

Para o desenvolvimento da pesquisa estão sendo considerados os alunos do Colégio Estadual Pedro Vieira Januário, que cursam o ensino médio em tempo integral. A restrição da pesquisa somente aos alunos dessa instituição se justifica pelo fato de ser uma modalidade relativamente nova à realidade do município, nunca houve na história da cidade, uma escola nesse formato. Sendo uma novidade em nosso cenário, a pesquisa objetiva discutir a realidade do jovem que mora no campo e que precisa dedicar todo seu tempo diurno às atividades escolares na cidade. Várias questões permeiam essa discussão, como: Que profissão deseja ter no futuro? Ele pretende algum dia migrar definitivamente para cidade? As respostas dessas perguntas nortearão o trabalho, na tentativa de compreender se a juventude rural desse município anseia por um modo de vida diferente de sua atual condição e, de maneira generalizada, compreender as dinâmicas e os processos que permeiam a realidade de tantos jovens brasileiros em perspectivas semelhantes.

No Colégio Estadual Pedro Vieira Januário, como já foi dito anteriormente, estão matriculados 165 alunos que cursam o ensino médio em período integral. A partir deste total de alunos, e das informações que foram acessíveis, a pesquisa se preocupou em estabelecer a relação dos alunos que residem na cidade, aqueles que residem no perímetro urbano, e os alunos que residem na zona rural, que residem no perímetro rural. Segue o gráfico. 
Gráfico 1 - Relação de alunos do campo e alunos da cidade

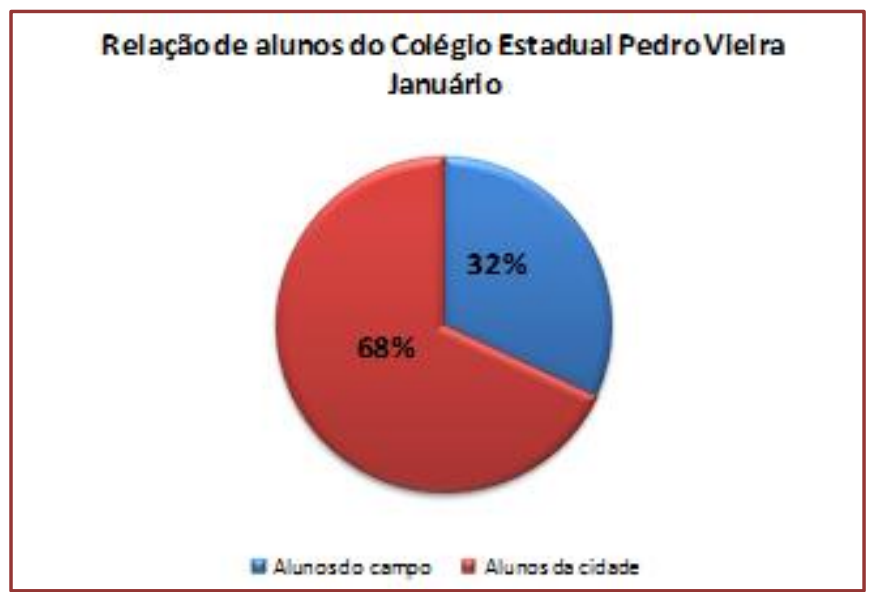

(Fonte: pesquisa de campo, 2018)

Como pode ser visto no gráfico acima, o Colégio Estadual Pedro Vieira Januário, em seu total de alunos, apresenta um quantitativo maior do número de alunos que residem na cidade, $68 \%$, enquanto que o percentual de alunos que residem no campo é menor, apenas $32 \%$. Esse fator pode ser influenciado pela modalidade de ensino em período integral que não oferece uma flexibilização de tempo aos alunos. Nesse sentido, os alunos que residem na cidade apresentam maior dedicação aos estudos. Quanto ao alunos do campo, pretende-se investigar se a dedicação dos estudos em tempo integral não ocorre devido ao tempo dedicado às atividades realizadas no campo ou por um outro fator determinante.

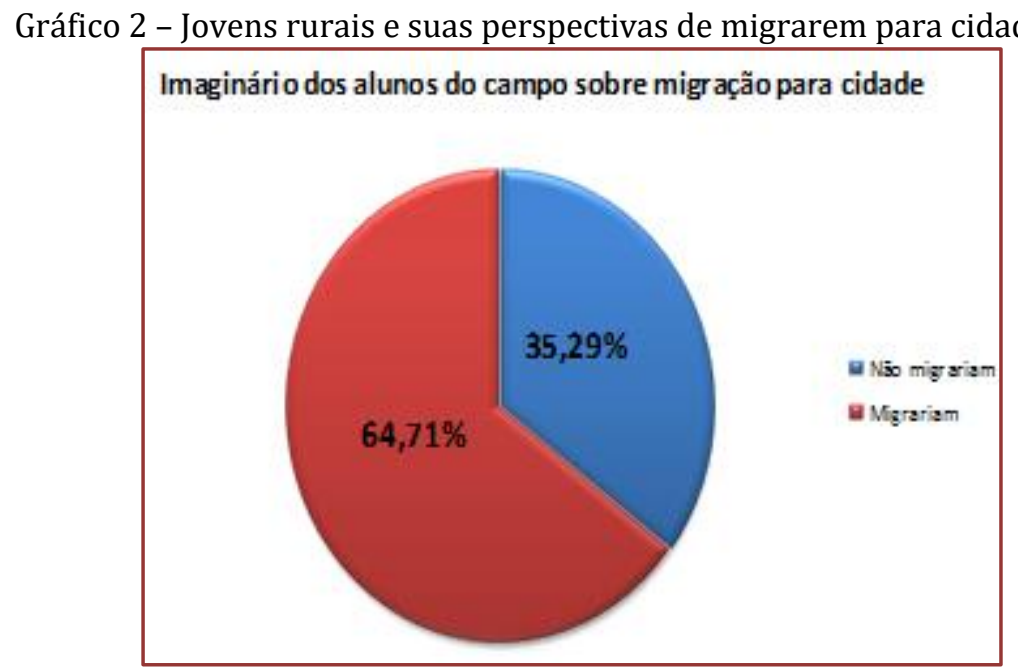

(Fonte: pesquisa de campo, 2018)

Neste gráfico está sendo representando o desejo e o imaginário dos jovens do campo de se estabelecerem definitivamente na cidade. Para a grande maioria, 64,71\%, migrar para cidade não é algo inimaginável. Porém, em 35,29\% dos jovens do campo ainda persiste o desejo de permanecer no campo. Podem ser múltiplos os fatores que estimulam esse desejo, os "fatores de expulsão" e os "fatores de atração" que influenciam diretamente a realidade e, consequentemente, o imaginário de cada um deles. 


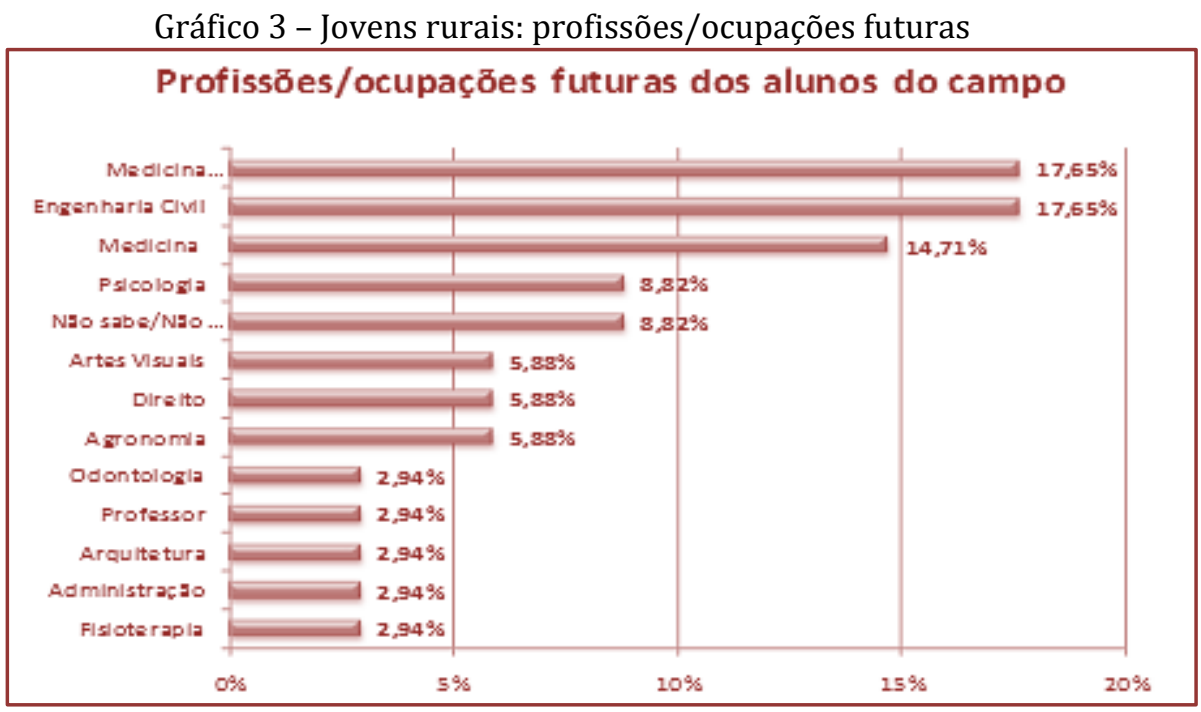

(Fonte: pesquisa de campo, 2018)

0 gráfico 3 é a síntese das perspectivas profissionais dos jovens do campo. Como podemos visualizar, há uma diversificação de atividades que esses jovens desejam exercer no futuro. Essa questão expõe como, de fato, estão impulsionados a manter suas relações com o campo ou rompê-la de alguma forma. Os índices mais expressivos são representados pela "Medicina veterinária", correspondendo a 17,65\%, e pela "Engenharia civil", correspondendo também a 17,65\%. É importante observar que dentre a lista a categoria "Agronomia" teve uma representação de apenas 5,88\%, o que nos permite dizer que são poucos os jovens do campo que pretendem manter a atividade com a agricultura familiar.

\section{DILEMAS E PERSPECTIVAS DA JUVENTUDE RURAL NA CONTEMPORANEIDADE}

Embora essa discussão seja pertinente ao nosso tempo, em outros séculos formularam-se indagações a respeito. Através do advento do capitalismo, a classe dos agricultores sofreu profundas transformações. Durante todo esse tempo, devido a tantas mudanças na estrutura política, econômica e social, essa categoria tem apresentado certa incapacidade de se estabelecer nesse sistema subordinado ao capital. Karl Marx em sua análise e teoria histórica antecipou o questionamento sobre a vida rural e seus desdobramentos. Nessa perspectiva, autores com a abordagem marxista apontam:

0 capitalismo tomou a terra um bem de capital; pôs fim à propriedade comunitária; transformou a produção urbana e agrícola em valores-de-troca; fez do mercado translocal o locus privilegiado da vida socioeconômica; atraiu trabalhadores para o centro urbano em busca de empregos; efetivou a produção de mercadorias em larga escala; expulsou do campo famílias inteiras. Tudo isso culminou na separação dos produtores diretos (artesãos e pequenos agricultores) de seus meios de produção, ao convertê-los, tão somente, em proprietários apenas de sua força de trabalho, enquanto etapa elementar para a geração da mais-valia. Neste sentido, a cada progresso da economia de mercado ocorria uma intensa fragilização da economia campesina, que anteriormente bastava a si mesma. (RAMALHO; MOREIRA, S/D, p. 188-189)

No entanto, os dados demográficos sobre a população brasileira demonstram a continuidade do processo migratório campo-cidade nas últimas décadas. No que diz respeito a Goiás, a população total é representada por 6.003 .788 habitantes, dentre estes a população urbana total corresponde a 5.420 .714 habitantes e a população rural total 583.074 habitantes, sendo 317.441 homens e 265.633 mulheres (CENSO, 2010). Dados como esses demonstram que cada vez mais, especialmente os jovens, trocam o campo pela cidade. 
Umas das justificativas para isso é que quando o jovem passa a ter maiores responsabilidades dentro da propriedade rural, em relação aos deveres como agricultor seja ele produtivo, econômico ou social, ele passa a visualizar e sentir as dificuldades que a agricultura familiar tem encontrado ao longo dos anos, em relação à dificuldade de crédito, assistência técnica, investimento em tecnologia, etc. A partir do momento que ele se envolve com esses problemas, o seu desenvolvimento pessoal se torna mais difícil, pois é nessa fase da vida que eles estão planejando a realização de seus projetos pessoais que muitas vezes são interrompidos pelas condições que o núcleo familiar se encontra (SPANEVELLO e VELA, 2003).

Os fatores que motivam a emigração rural estão divididos entre os atrativos da vida rural (que são fatores de atração) e as dificuldades da vida no meio rural e da atividade agrícola (que são os fatores de expulsão) (BRUMER, 2007). De acordo com Brumer (2007: p.3)

Apesar do peso dos fatores estruturais, as decisões sobre a migração são tomadas por indivíduos, que variam na avaliação de fatores de atração ou de expulsão. Ademais, na decisão de migrar, provavelmente os fatores de expulsão são anteriores aos de atração, na medida em que os indivíduos fazem um balanço entre s situação vivida e a expectativa sobre a nova situação. Dependendo de como se examina a questão, os estudos sobre a migração dos jovens focalizam ora os atrativos no novo ambiente ora os aspectos vistos como negativos no local de origem. Entre os "ruralistas" predominam as análises que apontam ante os fatores de expulsão do que os de atração, como causas de migração.

Além disso, o histórico de ausência de políticas públicas no Brasil, a dificuldade e insuficiência dos serviços de saúde e de educação de boa qualidade, bem como o acesso ao lazer tem reduzido a vontade dos jovens permanecerem vivendo na zona rural. A falta de apoio para a criação de alternativas de trabalho e meios diversificados para a composição de renda aumenta mais ainda a tendência dos jovens deixarem o campo, que muitas vezes são incentivados até pelos próprios pais por acreditarem que na cidade terão todas as oportunidades para a concretização dos seus sonhos (SILVA, 2012).

De modo geral, a baixa educação e a insuficiência de políticas públicas têm gerado vários problemas, entre os quais se pode fazer referência ao analfabetismo; grande número de crianças e jovens fora da escola; a carência de ensino rural; não valorização e formação de docentes; docentes alheios à realidade rural; abandono da escola rural; ausência de infraestrutura adequada; carência de renovação pedagógica; escolas deslocadas das necessidades e das questões do mundo real e alheia aos interesses dos trabalhadores rurais, de seus movimentos e organizações, e assim estimuladora do abandono do campo.

É importante observar que para cursar o ensino médio, em geral, o jovem rural precisa ir para as sedes dos seus municípios regularmente, onde terão acesso á outra forma de vida e diferentes modos de relacionamento social ao qual começarão a confrontar os valores da vida no campo e na cidade e despertarão o desejo de viver tal modo de vida diferente do qual foram criados (SIQUEIRA, 2004).

Outro fator apontado em outras pesquisas sobre jovens rurais é a predominância de homens no campo, pois a maior parte dos emigrantes são moças, levando à respectiva masculinização do campo. A situação mais delicada das mulheres deriva da desvalorização das atividades realizadas por elas, por serem trabalhos mais leves que são considerados como uma "ajuda", isso as torna pouco visíveis (PAULILO, 2004) e também pelo pouco espaço a elas reservado na atividade agrícola, onde atuam apenas como auxiliares (BRUMER, 2007). Essas situações fazem com que ocorra o desinteresse por parte das mulheres na continuidade da vida no campo, que acabam buscando os centros urbanos em busca de trabalho remunerado e conhecimento, bem como uma melhoria de vida. Muitas vezes são até mesmo incentivadas pelos próprios pais a procurarem os centros urbanos por acreditarem que terão mais oportunidades de trabalho e não precisarão trabalhar no "pesado". Essa predominância de mulheres migrando para cidade não está ligada a condições favoráveis para esse gênero no mercado de trabalho urbano, mas sim a desvalorização do seu trabalho no campo e a falta de perspectivas que elas encontram (ABRAMOVAY, 1998). 
Um aspecto que vem sendo abordado ultimamente como sendo um fator para o êxodo rural é a falta de espaços que tragam cultura e lazer para o campo, pois são fatores de descontração e socialização que aliviam o estresse causado pelo desgaste do dia-a-dia de trabalho no campo, assim como a ansiedade e depressão. Assim, os jovens rurais procuram na cidade a realização dessas atividades de cultura e lazer (festas, prática de esportes, cinema, etc.), já que o campo é tido como um lugar de tranquilidade de descanso (CARNEIRO, 1998). De acordo com Carneiro (1998: p. 257), "a ausência de espaços de lazer é responsável, entre outros fatores, pela avaliação negativa do campo em relação à cidade e pelo desejo de migração".

Geralmente, o jovem rural começa a trabalhar no campo por volta dos 10 a 12 anos de idade, realizando algumas atividades mais simples, e por volta dos 16 ou 17 anos muitas vezes já assume o papel de adulto na propriedade, eles acabam perdendo um pouco da vivência da adolescência no que diz respeito a atividades como lazer e recreação para assumir as responsabilidades a eles transferidas (OLIVEIRA, 2006).

Para além destas questões, propomos um diálogo no sentido de discutir a juventude rural como categoria invisibilidade e, consequentemente, como uma categoria estigmatizada. Antes de tudo, é importante considerar que a invisibilidade aqui se refere a situações em que determinados sujeitos se encontram imperceptíveis nas relações sociais. Trata-se de uma ação social que implica em não ver o outro, não enxergar sua existência social. Essa invisibilidade nega ao outro o direito ao reconhecimento e à identidade social. Entre tantos excluídos e marginalizados de nossa sociedade atual, os jovens rurais também estão presentes. A invisibilidade social a que estes jovens estão submetidos consiste numas das expressões de exclusão social, inviabilizando, sobretudo, sua própria condição de existência de direitos sociais.

De acordo com Carneiro e Castro (2007), uma questão central para a invisibilidade são as posições distintas entre "mundo rural" e "mundo urbano" em nossa sociedade. A análise da categoria juventude rural revela como essa hierarquia entre "mundo rural" e "mundo urbano" permanece e opera no cotidiano das pessoas. Esta ainda é umas das questões que mais aparecem em entrevistas com jovens rurais. Quem se identifica como jovem rural sente cotidianamente o estigma de viver no campo.

Por essas e outras questões, entendemos que não há um único modo de ser jovem, uma vez que este é influenciado por suas experiências, história e práticas sociais. Todavia, ser jovem também está ligado a essas influências, as quais permitirão ao indivíduo exercer sua juventude de um modo ou outro. 0 jovem do campo que desde cedo se defronta com questões ligadas às dificuldades de acesso a terra, às expectativas em relação à produção familiar e ao esforço nas atividades agrícolas, por exemplo, tem marcas em sua forma de pensar e agir diferentes daquelas do jovem que mora na cidade.

A realidade do jovem do campo é complexa, razão pela qual não é suficiente se apoiar apenas na crise da agricultura familiar para explicar as novas modalidades dos processos migratórios. Uma questão identificada por Matos (2002) sobre a saída dos jovens do campo para a cidade se deve também à busca pelo "moderno", o que de acordo com o autor caracteriza a visão sobre o campo como atrasado ou primitivo, fazendo o jovem deste meio querer entrar nos "moldes" da juventude urbana ("moderna") para não ser visto ou não se ver como atrasado ou "inferior". Para isso, muitas vezes o jovem camponês busca se apropriar de novas tecnologias e do conhecimento acadêmico.

De modo geral, os jovens rurais estão ligados ao conservadorismo, atrelado ao passado e ao tradicional, muitas vezes considerados alienados, marcados pela agricultura e exploração da natureza, bem diferente dos jovens urbanos, atrelados à modernidade e ao futuro e marcados pela urbanização e industrialização. Essa dicotomia rural-urbana, gera uma concepção negativa e estigmatizante dos jovens do meio rural, associados ao atraso e ao isolamento e fadados ao desaparecimento diante da tendência crescente da urbanização do país.

\section{JUVENTUDE RURAL: ESTIGMA E INVISIBILIDADE SOCIAL}

Em pleno século XXI, os povos do campo ainda não foram contemplados pelas muitas conquistas da modernidade. 0 contraditório está no fato de que a modernização da agricultura é um fenômeno há décadas. Porém, não é verdade que essa categoria faz parte de uma população considerada relevante. 
Antes de tudo, é importante considerar que a invisibilidade aqui se refere a situações em que determinados sujeitos se encontram imperceptíveis nas relações sociais. Trata-se de uma ação social que implica em não ver o outro, não enxergar sua existência social. Essa invisibilidade nega ao outro o direito ao reconhecimento e à identidade social. Entre tantos excluídos e marginalizados de nossa sociedade atual, os jovens rurais também estão presentes. A invisibilidade social a que estes jovens estão submetidos consiste numa das expressões de exclusão social, inviabilizando, sobretudo, sua própria condição de existência de direitos sociais.

De acordo com Carneiro e Castro (2007), umas das questões que contribui para a invisibilidade dos jovens rurais é que:

a juventude rural é percebida como uma categoria específica, e não na perspectiva de jovens e rurais. É uma categoria minoritária "dentro" da juventude. Quando retomamos os dados da PNDA essa análise faz sentido. Os dados apontam que a população de 15 a 29 anos é de 49 milhões de pessoas e representa $27 \%$ da população. Por outro lado, $4,5 \%$ seriam jovens rurais. No entanto ainda que pareça pouco no universo total, estamos falando de 8 milhões de pessoas. Isso sem entrarmos na problematização da própria definição de rural e urbano. Assim, se fôssemos pensar a juventude rural como categoria específica e de pouca expressão numérica na sociedade brasileira, esse eixo deveria ser revisto. É uma população de 8 milhões de jovens! Nesse sentido, a invisibilidade que marca a juventude rural deve ser problematizada (p.129).

Ainda de acordo com Carneiro e Castro (2007), uma questão central para a invisibilidade são as posições distintas entre "mundo rural" e "mundo urbano" em nossa sociedade. A análise da categoria juventude rural revela como essa hierarquia entre "mundo rural" e "mundo urbano" permanece e opera no cotidiano das pessoas. Esta ainda é umas das questões que mais aparecem em entrevistas com jovens rurais. Quem se identifica como jovem rural sente cotidianamente o estigma de viver no campo. Assim acrescenta:

há uma desqualificação simbólica que associa o rural, o camponês, a roça, o trabalhador rural, o agricultor familiar à imagem do atraso. Essa construção simbólica, muitas vezes, é reproduzida pelos próprios trabalhadores rurais, como diria Pierre Bourdieu, como "classe objeto", ou seja, o "camponês reproduz as concepções urbanas sobre o campo" (CARNEIRO e CASTRO, 2007, p. 130)

Assim, o jovens rurais são atingidos frontalmente e cotidianamente pelo estigma do movimento contraditório de viver no campo, estabelecendo tensões segregatórias que cumprem papel de "desqualificação simbólica, associada ao rural, o camponês, a roça, o trabalhador rural, o agricultor familiar a ideia de atraso" (CARNEIRO e CASTRO, 2007, p.129)

Em todo caso, é importante considerar que o estigma dos jovens rurais não está sendo caracterizado como um estigma físico, pois não está sendo considerado os atributos condicionados à natureza desse estigma e também não está sendo considerado um estigma de caráter individual, pelo contrário, se refere a vários indivíduos que compartilham o mesmo modo de vida que remete à cultura camponesa ou rural.

A construção do estigma dos jovens rurais se deu em oposição ao urbano. Os indivíduos provenientes do meio rural, em especial os jovens, sempre foram vistos como sujeitos exilados, distantes dos centros urbanos, sujeitos pacatos que vivem em meio às tradições patriarcais, enquanto que os indivíduos urbanos são representados pela agitação e pelo movimento das vias públicas e seus rumores, elementos vinculados aos signos do mundo moderno. Assim,

[...] o sujeito rural com vida parasitária, em um lugar distante, situado na depressão profunda entre as montanhas de relevo fortemente desnivelado e de difícil acesso e, por esse motivo, um lugar esquecido e não frequentado pelas pessoas. Seu saldo seria: abandono, isolamento, atraso e esquecimento (SILVA, p. 73, 2012). 
De modo geral, os jovens rurais estão ligados ao conservadorismo, atrelado ao passado e ao tradicional, muitas vezes considerados alienados, marcados pela agricultura e exploração da natureza, bem diferente dos jovens urbanos, atrelados à modernidade e ao futuro e marcados pela urbanização e industrialização. Essa dicotomia rural-urbana, gera uma concepção negativa e estigmatizante dos jovens do meio rural, associados ao atraso e ao isolamento e fadados ao desaparecimento diante da tendência crescente da urbanização do país.

\section{CONSIDERAÇõES FINAIS}

O jovem do campo, assim como afirmou Abramo (2005), ainda é um sujeito difícil de ser discutido, tendo em vista sua complexidade cultural e sua pouca representatividade nas pesquisas no que concerne a suas dinâmicas culturais e sociais. Contudo, ao discutirmos sobre os jovens rurais estudantes do município de Bela Vista de Goiás, podemos perceber as desigualdades desse jovem da contemporaneidade. 0 fato de ser jovem e de morar em área rural, o torna um indivíduo com dilemas e perspectivas distintas, as quais muitas vezes estão relacionadas ao modo de ver e viver a vida.

Compreendemos que os jovens vivenciam diferentes contextos em seu cotidiano, alguns comuns a outros jovens, outros específicos aos seus espaços de vivência. Os jovens do campo, singularmente, são indivíduos que vivenciam a dinâmica relação entre campo e cidade e são influenciados constantemente por esta. Por isso, procuramos compreendê-los enquanto indivíduos ativos que, em situações plurais, fortificam e produzem aquilo que é expresso em sua identidade.

A análise desses jovens e suas concepções de rural e urbano não se esgotam nas discussões realizadas nesta pesquisa, uma vez que surgem novos olhares e diferentes aspectos de análise. Assim, é importante dizermos que, com esse estudo, esperamos contribuir e despertar ainda mais olhares para investigações relacionados às juventudes, em especial, para os jovens do campo e suas práticas socioculturais que se configuram, cada dia mais, como um importante elemento de análise. Compreendemos que os jovens vivenciam diferentes contextos em seu cotidiano, alguns comuns a outros jovens, outros específicos aos seus espaços de vivência. Os jovens do campo, singularmente, são indivíduos que vivenciam a dinâmica relação entre campo e cidade e são influenciados constantemente por esta. Por isso, é necessário compreendê-los enquanto indivíduos ativos que, em situações plurais, fortificam e produzem aquilo que é expresso em suas linguagens, organizações e territorialidades.

\section{REFERÊNCIAS}

[1] Abramo. H., W.; Freitas, M., V., Sposito, M., P. (Org.). Juventude em debate. São Paulo: Cortez, 2000.

[2] Abramo, H. W. Condição juvenil no Brasil contemporâneo. In: Abramo, H. W.; Branco, P. P. M. Retratos da juventude brasileira: análises de uma pesquisa nacional. São Paulo: Instituto Cidadania; Fundação Perseu Abramo, 2005.

[3] Abramovay, R. et al. Juventude e agricultura familiar: desafios dos novos padrões sucessórios. Brasília, DF: UNESCO, 1998.

[4] Abramovay, R. Ruralidade e desenvolvimento territorial. Gazeta Mercantil, São Paulo, p. A3. 15 abr. 2000.

[5] Bourdieu, Pierre. A “juventude” é apenas uma palavra! Questões de sociologia. Rio de Janeiro: Marco Zero. p. $112-121,1983$.

[6] Brumer, Anita. A problemática dos jovens rurais na pós-modernidade. In: Carneiro, Maria José; Castro, Elisa Guaraná de. Juventude rural em perspectiva. Rio de Janeiro: Mauad, p.35-51, 2007.

[7] Carneiro, Maria José. Castro, Elisa Guaraná de. Juventude Rural em perspectiva. Ed. Editora Mauad, 2007.

[8] Carneiro, Maria José. Ruralidade: novas identidades em construção. Estudos Sociedade e Agricultura, n.11, Rio de Janeiro: CPDA/UFRRJ, p. 160-257, 1998.

[9] Carneiro, Maria José. Castro, Elisa Guaraná de. Juventude Rural em perspectiva. Ed. Editora Mauad, 2007.

[10] Castro, E. G. Os jovens estão indo embora?: juventude rural e a construção de um ator político. Rio de Janeiro: Mauad X; Seropédica; EDUR, 2009.

[11] Censo Agropecuário $2006 . \quad$ Disponível em: http://www.ibge.gov.br/home/estatistica/economia/agropecuaria/censoagro/ Acesso em: 13 de Janeiro de 2018.

[12] Censo Demográfico 2010. Disponível em: http://censo2010.ibge.gov.br/ Acesso em 03 de Janeiro de 2018. 
[13] Frossard, Antônio Carlos. Identidade do Jovem rural confrontando com estereótipo de Jeca Tatu. Um estudo qualitativo com os jovens da EFA Rei Alberto I. Dissertação de Mestrado - Faculdade de Ciências e Tecnologias da Educação. Universidade Nova de Lisboa. Portugal. Nova Friburgo. RJ. 2003.

[14] Hall, Stuart. A identidade cultural na pós-modernidade. Trad.: Tomaz Tadeu da Silva, Guaracira Lopes Louro. 3. ed. Rio de Janeiro: DP\&A, 1999.

[15] Instituto Brasileiro de Geografia e Estatística (IBGE) 2016 - Disponível em: http://ibge.gov.br/home/estatistica/populacao/estimativa2015/default.shtm Acesso em: 12 de Maio de 2018.

[16] Matos, A. G. de. "Desenvolvimento, autonomia e academia”. In: LIMA, D. M de A. e Wilkinson, J. (orgs). Inovação nas tradições da agricultura familiar. Brasília: CNPq/Paralelo 15, 2002.

[17] Novaes, Regina. Juventude/juventudes? Em comunicações ISER, (50), ano 17, Rio de Janeiro: ISER, 1998.

[18] Oliveira, Edmar Geraldo. O lazer e a melhoria da qualidade de vida dos jovens rurais de São João Evangelista - MG. Dissertação (Mestrado em Meio Ambiente e Sustentabilidade). Centro Universitário de Caratinga. Caratinga: UNEC, 2006.

[19] Paulilo, Maria Ignez. Trabalho familiar: uma categoria esquecida de análise. Florianópolis, p.52-229, 2004.

[20] Prediger, Solange. Estado da Arte da Situação do Jovem rural: a construção de identidades. Revista Anagrama: Revista Cientifica Interdisciplinar da Graduação. Ano 3. Ed. 1 Setembro/Novembro de 2009.

[21] Ramalho, C.W.N.; Moreira, R.N.P.; A visão escatológica de Marx e Engels sobre o campesinato e a vida local rural. Estudos de Sociologia. Rev, do Progr. de Pós-Graduação em Sociologia da UFPE, v. 16, n. I, p. 179- 208, S/D.

[22] Silva, Luciana Meire da. Cidades mortas: o rural como sinônimo de atraso e decadência. Plural, Revista do Programa de Pós-Graduação em Sociologia da USP, São Paulo, v.19.2, 2012.

[23] Siqueira, Luiza Helena Schwantz. As perspectivas de inserção dos jovens rurais na unidade de produção familiar. Porto Alegre (Dissertação de Mestrado), Universidade Federal do Rio Grande do Sul, UFRGS, 2004.

[24] Sposito, Marilia. "Considerações em torno do conhecimento sobre juventude e escolarização". In Osmar Fávero, Marília Pontes Spósito, Paulo Carrano \& Regina Reyes Novaes, Juventude e contemporaneidade. Brasília: MECINEP/Comped.,p. 7-34, 2002.

[25] Spanevello, R.M.; Vela, H.A. Os fatores limitantes ao desenvolvimento dos jovens rurais pertencentes à agricultura familiar do município de Nova Palma/RS. Revista de Pesquisa e Pós-Graduação - Santo Ângelo/RS, p. 48$79,2003$.

[26] Zagury, T. O adolescente por ele mesmo. 14. ed. Rio de Janeiro: Record, 2004. 


\section{Capítulo 11}

\section{O processo de estigmatização do "baiano" na cidade de Rio Grande - RS}

\section{Pedro Marchioro \\ Pedro Robertt Niz}

Resumo: Com a instalação do polo naval na cidade de Rio Grande- RS em 2006, uma leva de mão de obra exógena aportou nessa região até então marcada pela moderação e estabilidade de sua atividade urbana. A chegada de estrangeiros não tardou a gerar conflitos de ordem cultural, sobretudo no encontro de culturas distintas, a saber, do gaúcho com os estrangeiros que passaram a ser identificado sob a figura do "baiano". 0 designativo "baiano" é uma categoria da qual o habitante local se utiliza visando denigrir aquele ao qual o termo é destinado e ao mesmo tempo restaurar a realidade social daquele que o enuncia. "Baiano", portanto, pouco tem a ver com a identificação do habitante do estado da Bahia. 0 termo se dirige a trabalhadores cariocas, paulistas, pernambucanos, paraibanos, e de outras regiões do Brasil que vieram ocupar os postos de trabalho abertos no polo naval riograndino em função ausência de mão de obra qualificada na região. Desse modo "Baiano" seria antes um aglomerado de diferenças transformadas em semelhanças para serem reunidas em uma mesma categoria a partir de afinidades construídas e sustentadas por dispositivos de linguagem assim como por mecanismos de produção de consenso. 


\section{INTRODUÇÃO}

Esta exposição é parte da pesquisa de mestrado apresentada em 2016, a qual abrangeu temáticas sobre migrações, choque cultural, crises de identidade e representação. Tomando o estudo de caso como ponto de apoio, propõem-se aqui apresentar sucintamente uma reflexão sobre como a inserção de novas figuras, tal como migrantes e estrangeiros, impactam em determinada configuração social e como esse impacto se manifesta nas subjetividades dos agentes que a vivenciam, perguntando-se, por exemplo, de que estratégias se valem para restaurar as cadeias rompidas, as descontinuidades intelectivas, os desconfortos afetivos, etc., valendo-se da produção de novos esquemas de representação e inteligibilidade, assim como da manipulação dos signos e sentidos que constituem tal realidade. Debruçando- se sobre esse caso, podese vir a ter maior conhecimento sobre os processos de assimilação a que estão sujeitos aqueles contextos que se tornam focos de impulsos migratórios, assim como sobre os elementos de estruturação de grupos que compõem e são compostos pelas configurações sociais.

Desde os primeiros impulsos da reativação do polo naval de Rio Grande passou a haver uma alta incidência de "estrangeiros" na região. E já nos primeiros assentamentos destes migrantes pode-se perceber os conflitos e estranhamentos que eram divulgados pela mídia local assim como por outros veículos de informação. Desde aí, notava-se um tipo de opinião geral se formando em torno do "nordestino", que aqui aparecia sob a figura do "baiano". Seguindo pistas levantadas nas redes sociais, foi possível confirmar a existência do conflito. A partir daí, tomou-se a problemática em termos de uma hermenêutica do conflito, ou seja, um lugar desde onde se faz possível investigar os processos de estruturação social, tendo em conta que macromudanças - aquilo que diz respeito às causas gerais da migração - geram efeitos que se manifestam em microespaços - as aversões manifestas nas falas e nos corpos, os desconfortos provindos das transformações do cotidiano traduzidos em atos de fala, gestos, etc.

Percorrendo o caminho por onde o rótulo "baiano" se erigiu, percebemos que o termo não se sustenta sobre demarcadores regionais ou étnicos. Isto é, "baiano" poderia ser tanto alguém nascido no estado da Bahia, quanto em Pernambuco, Piauí, Paraíba, Ceará, Rio de Janeiro, São Paulo ou Minas Gerais, como diz um comentário na internet: "Eu tenho nojo dessa gente, um bando de maloqueiros porcos, baianos, cariocas e merda é tudo a mesma coisa". 0 modo de identificar um "baiano" desde o início mostrava-se muito precário na fala dos agentes nativos e a aplicação muito variável, dependendo de vários fatores. Como nessa fala: "Como identificar um baiano no polo naval em Rio Grande: É muito fácil, se tiver um celular num ouvido e uma latinha na mão, já achou." Quer dizer, a aplicação do pejorativo não funciona segundo constatações de laços regionais, nem obedece a distinções de natureza étnica ou racial, tampouco ao clássico recorte de classe. Os estrangeiros ganham em média igual ou até mais do que os nativos, são mais qualificados no ramo naval - daí a necessidade de sua incorporação ao polo. Outros autores (ELIAS \& SCOTSON, 2000) já haviam destacado a aleatoriedade dos sinais que fundamentam os argumentos de inferiorização, tal como cor, religião, gênero, etc. Nesse sentido, haveria que se indagar como se origina o hábito de perceber as pessoas com outra cor de pele, sexo ou outros predicados, como pertencentes a um grupo diferente.

Foi essa perspectiva que norteou esse estudo. Partindo dela, foi possível observar os traços e sinais de demarcação grupal em seu processo embrionário de construção. Em um segundo momento, foi possível observar como a representação do "baiano" foi utilizada no percurso inverso, de operacionalização dedutivista de certos traços previamente agrupados nele. A esta prática de reconhecimento e posicionamento em relação a estes traços agrupados em uma representação, entende-se aqui como estigmatização, prática esta semelhante ao que se denomina "racismo" ou "xenofobia", com a diferença de que aqui se descarta a possibilidade de que existam traços ou demarcadores existentes em si, ao que caberia à inteligência humana identificá-los a posteriori. Aqui, tais práticas seriam, em síntese, nada mais do que o final de uma longa cadeia de construções sociais que constroem e mobilizam diferenças para justificar o pertencimento a grupos ou realidades distintas - sempre em termos de hierárquicos. Sua força residindo na capacidade de sustentá-las e reproduzi-las.

\section{DESCRIÇÃO DO CONTEXTO}

Em 2005 na cidade de Rio Grande, localizada no sul do estado do Rio Grande do Sul, é instalado o polo naval. Com isso a região passa a integrar o circuito global de construção de plataformas para a exploração de petróleo. A cidade de aproximadamente 200 mil habitantes, vinha apresentando índices muito pouco expressivos de movimentação comercial e urbana, isso em parte pelo isolamento geográfico - que acabava por gerar ainda mais isolamento - em parte por outros fatores políticos, históricos e culturais próprios dessa região sul do estado. 
A partir de então há um grande volume de materiais, investimentos e recursos vindos de outros lugares do Brasil e do mundo, que alterarão "significativamente o perfil produtivo da metade sul, bem como suas condições socioeconômicas". (Plano Diretor do Polo Naval, p.

4) Junto a esses novos elementos, uma profusão de matéria humana - forasteiros de caras novas, pessoas de todas as partes, cheia de sotaques e cores, com comportamentos desconhecidos e estranhos à percepção do riograndino - passa a circular na cidade.

Rapidamente as ruas da cidade são infladas, vê-se acelerar seu movimento com fluxos de trabalhadores de uniformes de todas as cores. Fala-se muito sobre o polo. A televisão exalta um "novo eldorado", ou, como no titulo da edição da reportagem do Globo Repórter de fevereiro de 2011, um "novo mapa da prosperidade brasileira". Nos jornais, pululam anúncios de vagas de emprego: soldador, encanador, pintor, etc. Cursos são oferecidos para treinamento junto a incentivos de profissionalização para os postos de trabalho do polo. Nas portas das empresas há filas para o preenchimento do cadastro de emprego. Exemplos são divulgados de pessoas que abandonaram suas antigas fontes de renda e vieram a ter relativo sucesso no polo.

É desse enfrentamento inicial entre a população local e a massa confusa de estrangeiros, intensificado pelo volume e velocidade em que se deu as instalações dos megaempreendimentos, que emergirá as primeiras denuncias e acusações do (mal) comportamento do "baiano", figura de linguagem que age no sentido de condensar toda a miscelânea de caras novas, hábitos embaraçados, sotaques diversos, comportamentos desviantes, que apareceu na nova configuração da realidade de Rio Grande.

Mais adiante, demonstrar-se-á como esta imagem se tipifica, é reificada, isto é, se descola das situações imediatas que o geraram, passando a constituir um elemento a mais no universo simbólico do riograndino, estratégico na conduta de sua nova vida diária.

É interessante perceber o contraste entre o que Rio Grande era e o que veio a ser em um período bastante curto, descrever o seu pano de fundo para facilitar a compreensão da sociogênese do estigma (QUINONES e SUPERVIELLE, 2015, p. 18), isto é, do estigma enquanto uma relação, dado que o fenômeno não acontece num vazio social (ELIAS, 2000, p. 32). Nesse sentido, o defrontamento das distintas culturas - de onde emergirá o estigma - devem-se a uma série de circunstâncias. Desse modo, a hermenêutica do conflito no polo naval de Rio Grande aponta primeiramente para a interdependência entre extrangería (BLANCO, 2006) e cultura nativa, o que Elias e Scotson (2000), denominam "abordagem figuracional". Isto é, o fato de que

as categorias estabelecidos e outsiders se definem na relação que as nega e que as constitui como identidades sociais. Os indivíduos que fazem parte de ambas estão, ao mesmo tempo, separados e unidos por um laço tenso e desigual de interpendência. (ELIAS, 2000, p. 8)

Portanto, o encontro entre o nativo e o estrangeiro do qual emergem os fenômenos estigmatizantes, devem-se antes de mais nada ao polo naval. Numa rápida descrição pretendo esboçar o cenário em que esse encontro se deu para que possamos tomar parte da perspectiva do nativo, o "empreendedor" (BECKER, 2008) primeiro e ultimo desse mecanismo que é o estigma.

\section{ESBOÇO DO CENÁRIO EM QUE O ESTRANGEIRO INGRESSA}

O polo naval fica no município de Rio Grande, mas não se reduz a esse. Na verdade ele diz respeito a um aglomerado que abarca as cidades de Pelotas, São José, São Leopoldo, Jacuí, Cachoeira do Sul, Charqueadas, Porto Alegre e a lista ainda continuaria se ponderássemos seus efeitos gerais. E é nesse sentido que perguntamos sobre os "porquês" e os "comos" dessa região sul, sempre menos desenvolvida em relação ao norte do estado, passar a integrar o itinerário da circulação global de capital.

Em 1997 o porto de Rio Grande foi incluído no programa de renovação da frota nacional de apoio marítimo, basicamente na construção de embarcações da marinha mercante. Porém, em 2006, interrompe-se esse programa em função da confirmação da descoberta da camada pré-sal na costa brasileira, deslocando-se o foco para o investimento em tecnologias para extração e manipulação do petróleo na costa brasileira (FABRES, 2014).

Rio Grande teve um dos primeiros portos de atracação de barcos do Brasil, de modo que a cidade já apresentava em seu histórico uma atividade portuária de transporte e armazenamento de mercadorias. Entretanto, esta é a primeira vez que ela é anexada a um nível de trocas globais, sobretudo se ressaltarmos 
que, justamente nas décadas em que o mundo intensificava as trocas globais, ela estivera fechada em seu isolamento. Assim, fica claro que Rio Grande não encontraria resposta para o desafio ao qual era solicitada unicamente em seus recursos internos, e é nesse sentido que passa a importar trabalhadores já qualificados nas atividades do setor petrolífero.

Há ainda o fato de que o próprio trabalhador nativo, uma vez estando qualificado para esse setor ou atividades afins, passem a tomar o circuito do trabalhador móvel, a procura de

postos onde suas ocupações sejam compatíveis. Observa-se assim que uma espécie de constante rotatividade vai se instituindo numa cidade que vinha apresentando uma dinâmica urbana bastante tímida, e que encontra dificuldades para lidar.

\section{ESPAÇOS DE CONFLITO: REDES SOCIAIS}

Rio Grande tem o mar, tem a lagoa dos patos, e por isso o destino de viver das águas, com suas ondas, seus altos e baixos. A cidade mais antiga do Rio Grande do Sul já foi a mais importante e esteve na lista das mais pobres, agora, vive um novo tempo de prosperidade. (GLOBO REPÓRTER; reportagem de 11.02.2011)

Assim iniciava a reportagem do Globo Repórter cujo subtítulo era: "O novo mapa da prosperidade brasileira". Na reportagem, que, segundo o presidente do sindicato dos metalúrgicos, foi "irresponsável", a zona do polo naval situava-se entre as cidades mais promissoras do país.

No outro dia dessa reportagem, que eu digo, irresponsável, o que apareceu de pessoal de Piauí, Maranhão, São Paulo, Rio de Janeiro, de mochila no sindicato: "Companheiro eu quero saber onde é que eu ficho?", eu dizia "como assim?", "Rapaz, eu vi ontem a reportagem e agora tô aqui". 0 cara escutou a reportagem de noite, de manhã pegou um avião (...), e chegou aqui no outro dia da reportagem, cobrando a vaga dele. (Programa Contraponto, 2014)

É nesse sentido que desde os primeiros impulsos da reativação do polo naval de Rio Grande tem havido uma alta incidência de "estrangeiros", atraídos certamente por tal prosperidade. E, já nos primeiros assentamentos destes migrantes podia-se perceber os conflitos divulgados pela mídia local assim como por outros veículos. Via-se um tipo de opinião formando-se a respeito do nordestino, que ia aparecendo na figura do "baiano". Em uma rápida busca na internet pôde-se confirmar a existência do conflito.

Entendemos que todo o espaço do conflito é o espaço do conflito em potencial, isto é, que o conflito está inscrito nos espaços de forma latente podendo manifestar-se ou não e em diferentes graus e sob diversas formas. Isso porque os espaços sociais estão imbuídos de regras, sendo essas formais ou informais mas sempre pressupondo a sua infração (GOFFMAN, 1988; BECKER, 2008). Nesse sentido, toma-se as redes sociais como um espaço privilegiado para a observação dos conflitos sociais. Conflitos que iniciam em espaços públicos, vão se desdobrar, ganhar força e forma dentro das redes sociais. Como o "instrumento da fofoca descrita" por Elias e Scotson em Os estabelecidos e os outsiders (2000, p. 13), as redes sociais funcionam para os agentes como uma alavanca onde se tem a possibilidade de atingir o alvo sem que se veja de onde parte o ataque. Dito de outro modo, as redes sociais garantem um relativo anonimato, e assim oferecem uma maior segurança ao minimizar os custos emocionais com as acusações diretas, cara a cara. É nas redes que se vai consolidando a imagem do "baiano" e, em contraposição, a própria auto-imagem do nativo.

Utiliza-se, portanto, de ferramentas e técnicas para a investigação desse espaço virtual ainda um tanto recente nas ciências sociais, mas que já tem demonstrado sua importância e validade em estudos que investem em sua apropriação e transformação em local de produção de dados, tal como a etnografia virtual, o trabalho de campo online, a cibercultura, e outros. (DE SENA e LISDERO, 2014). Mobilizou-se assim dispositivos como o N-Vivo o programa SPSS para organização e analise de dados construídos tanto através de questionários e entrevistas de formas variadas, quanto através da coleta de informações nas redes sociais.

As redes sociais constituiriam um microcosmo onde se torna possível identificar o desenvolvimento desses conflitos em seu estagio mais desenvolvido e, sobretudo, em seu formato não-velado. Pois esta é uma das dificuldades quando se busca medir e demonstrar fenômenos, à primeira vista, de caráter dissimulado como o estigma. Numa sociedade democrática em que o direito às diferenças é defendido por lei, o estigma se daria através de mecanismos mais sutis e complexos, posto que o próprio agente estigmatizador sofreria prejuízo moral, isto é, estaria sujeito ao estigma ao estigmatizar. 
Desse modo, a apropriação do universo online propicia o levantamento de informações que não se mostram facilmente nem nas observações nem nas entrevistas diretas, mas que emergiram, por exemplo, em entrevistas feitas por email, Skype ou Facebook, e ainda em coletas de debates em fóruns que se desenvolveram no Youtube, tal como evidenciado nos trechos a seguir ${ }^{32}$ :

Eu particularmente não aguento mais barulho, porque é música de manhã cedo ou supertarde, ainda pegam a pior música, a pior mesmo, onde a cantora é super aguda e colocam pra repetir ate 7 vezes que foi o que contei...por favor né, é difícil receber bem essas coisas.

Vão toma no cú seus baianos de merda! Se a Bahia fosse bom não viriam para Rio Grande trabalhar! Vocês são abusados, folgados, seus mortos de fome! Chupa baianada filhos da puta!

Essa contundência com que o estigma se manifesta nas redes sociais, sobretudo porque preserva o anonimato e generaliza as aversões em entidade, não é encontrado nas ruas, nas situações ou encontros sociais cara a cara. Estas acusações também não aparecem nas entrevistas, uma vez que o entrevistador, em último caso, pode aparecer ao entrevistado como um representante do estado ou da cultura legitima (SUPERVIELLE e ROBERTT, 2015, p. 101). A internet, aqui, age como um dispositivo de manifestação das emoções retidas nas situações imediatas, permitindo que as acusações venham à tona sem risco de repreensão ou censura.

\section{A VIZINHANÇA}

Embora a internet se apresente como um espaço profícuo para a análise, o princípio do conflito, a que temos mapeado a partir das pistas levantadas nas redes sociais, reside na vizinhança. É nos encontros diretos, na imediaticidade do cotidiano que os atritos tendem a ser travados.

O fenômeno da estigmatização, no entanto, como já visto em outros estudos (ELIAS, 2000; BECKER, 2008, p. 29-30), apoia-se numa lógica mais profunda, subjacente aos deslocamentos do estigma, onde há um quadro de desequilíbrio de poder e distribuição de recursos, uma diferença no grau de organização e coesão dos grupos, e ainda uma diferença na participação daquela tradição que constitui as regras e acordos informais e os espaços de significação onde os comportamentos e seus sentidos estão previamente dispostos e são finitos: "os ambientes sociais estabelecem as categorias de pessoas que tem probabilidade de serem neles encontradas.” (GOFFMAN, p. 11-12; 1988).

Percorrendo o caminho por onde o rotulo "baiano" se erigiu, percebemos que o termo não está condicionado à região de origem daqueles que assim são identificados. Isto é, "baiano" pode ser tanto alguém nascido no estado da Bahia, quanto em Pernambuco, Piauí, Paraíba, Ceará, Rio de Janeiro, São Paulo ou Minas Gerais, como diz um comentário na internet: "Eu tenho nojo dessa gente, um bando de maloqueiros porcos, baianos, cariocas e merda é tudo a mesma coisa”.

O modo de identificar o baiano é muito precário e a aplicação muito variável, dependendo de vários fatores. Como nessa fala: "Como identificar um baiano no polo naval em Rio Grande: É muito fácil, se tiver um celular num ouvido e uma latinha na mão, já achou." Quer dizer, a aplicação do pejorativo não funciona segundo constatações de laços regionais, nem obedece a distinções de natureza étnica ou racial, tampouco ao clássico recorte de classe. Os estrangeiros ganham em média igual ou até mais do que os nativos, são mais qualificados no ramo naval - daí a necessidade de sua incorporação ao polo. Elias e Scotson (2000) já haviam destacado a aleatoriedade dos sinais que fundamentam os argumentos de inferiorização, tal como cor, religião, gênero, etc.:

Ao discutir os problemas "raciais", tende-se a por a carroça na frente dos bois. Afirma-se, em geral, que as pessoas percebem as outras como pertencentes a outro grupo porque a cor de sua pele é diferente. Seria mais pertinente indagar como foi que surgiu no mundo o habito de perceber as pessoas com outra cor de pele como pertencentes a um grupo diferente. (ELIAS, 2000, p. 46)

\footnotetext{
${ }^{32}$ Os termos foram conservados todos tal como retirados da internet, com seus palavrões e expressões vulgares, para preservar a força e o sentido no qual o conflito é verbalizado nas redes sociais. Já os nomes foram retirados ou modificados.
} 
É essa perspectiva que tem se mostrado adequada em nosso estudo. A seleção dos traços e sinais mostraram-se, primeiramente, em seu processo embrionário de seleção, reunião e tipificação em entidade-estigma. E, num segundo movimento, pudemos observar como o estigma, coisificado, foi utilizado no percurso inverso, de identificação dedutivista de certos traços previamente agrupados nele.

\section{EXPLANAÇõES TEÓRICO-METODOLÓGICAS}

Parte-se do postulado de que todo novo fenômeno ingressado na realidade é interpretado pelos atores sociais à luz das categorias de conhecimento já dispostas nos âmbitos sociais, ou no que Berger e Luckmann (1976) chamaram de estoque de conhecimento. É a partir nas interações no cotidiano que emergem objetivações que, num segundo momento, se destacam da situação imediata, do "aqui e agora" que o gerou, e passam a configurar categorias objetivas, tipos, padrões, figuras generalizadas, análogas ao estigma.

Essas tipificações jamais encontram correspondência perfeita nas interações face a face, mas tornam possível deduções, as previsões características do "conhecimento que dirige a conduta na vida diária" (BERGMAN e LUCKMANN, 1976, p. 35).

Há que se ter imagens que permitam perceber o outro como outro e como não-nós. Essas imagens independem dos sujeitos individuais (ELIAS e SCOTSON). Elas obedecem a uma sociodinâmica mais complexa que o simples racismo de cor, de gênero. Há uma construção social do "nós" e do "eles". 0 integrante do grupo outsider seria todo aquele que não faz parte do "nós", ou que são "nós" em menor grau. Junto ao processo de diferenciação, entretanto, há a definição de sinais indicativos que permitiriam operar essas diferenciações com mais facilidade. No caso da raça e do gênero, por exemplo, na linha de Elias e Scotson (2000), estas diferenças sedimentaram-se de tal maneira no longo processo histórico, que se torna difícil de desconstrui-las. É muito fácil distinguir uma mulher de um homem, pelo traço físico, ou, em ultima instancia, pela ausência de pênis e a capacidade de engravidar. No caso da raça o demarcador pode ser inferido pela cor, formato, etc. Há, entretanto, momentos em que estas evidências não são tão claras. Para Elias e Scotson (2000) há esse processo diacrônico que, transpassado de geração em geração, que vai se aperfeiçoando, se abstraindo, saindo da imprecisão para precisão auto-evidente. Citam o exemplo dos burakunins no Japão ou os judeus, que, por não serem facilmente distinguíveis por traço, cor, ou gênero, eram obrigados a usar uma faixa de identificação no braço.

Berger e Luckmann entendem que a realidade constitui-se na soma das tipificações acima esboçada. Esta realidade erige-se "acima" das subjetividades no sentido de que independem delas individualmente, porém são utilizadas individualmente para a conduta na vida diária. A gênese das tipificações tem seu princípio na interação imediata entre os agentes, mas progressivamente vai tomando forma, evoluindo até se descolar e independer dessa situação inicial que o gerou. Nesse momento, essa tipificação passa a integrar o estoque de conhecimento, a tradição, ou ainda a carga semântica da qual Schultz (2010) e mesmo Goffman (1988) refletirão para entender a condição complexa do estrangeiro e do estigma, as quais nos acompanharão durante o texto.

Esse desenvolvimento teórico um tanto quanto amplo, ilustra o que temos encontrado na analise dos movimentos que perpassam o estigma, basicamente, das subjetividades para a objetividade, e dessa novamente para as subjetividades. Quer dizer que, dez anos depois dos primeiros aportes do polo naval em Rio Grande, o estigma "baiano" já se tipificou, se reificou, isto é, está alocado na configuração da realidade social riograndina e pode ser encontrado nos discursos de seus habitantes como uma categoria auto-explicativa. Nesse momento, uma vez o estigma institucionalizado, passaríamos a notar o movimento contrário, de uso dos agentes individualmente nas situações de interação direta.

Postulamos ainda que uma mudança em uma dada realidade é acompanhada pela mudança na forma de compreendê-la. Novos instrumentos serão formulados porém a partir dos já existentes. Daí a precariedade que encontramos nas primeiras formulações acerca das categorias de compreensão dos fenômenos inéditos, tal como o ingresso massivo do estrangeiro.

Num primeiro momento, de encontro com o novo, há esforços no sentido de defini-lo, racionalizá-lo, como nessa de um trabalhador do polo:

São mal educados, não tem respeito por mulheres etc... Muitos são arrogantes... Mal educados. Se acham melhor que os outros.... Falam mal do estado, falam mal das mulheres.... E uma coisa que não aceito é falar mal do meu estado!!! Metem a mãe.... Falando besteiras para as mulher que passa!!! 
Ou nessa outra de uma cabeleireira:

Eles são "chinelo", grudentos, abusados. Se jogam em cima da gente. Outro dia um tentou me beijar no calçadão da praia (...) Tão sempre de chinelo, pode tá o frio que for, e de celular no ouvido (...) Eu não sei, eles têm uma cara assim, como vou te dizer, não é preconceito, mas eles tem uma cara de pobre.

Esse esforço de compreensão por parte dos agentes individuais, bastante variável nas falas, começa a ganhar corpo e continuidades nas redes. Deparamos-nos então com definições como esta na Disciclopédia, página que se assemelha a Wikipédia, a enciclopédia online, porém fazendo uma parodia dos temas:

Baiano é qualquer ser humano que more acima da linha da praça da Sé, que desembarca em São Paulo na Rodoviária do Tietê após 5 dias de viagem de ônibus com uma bagagem que inclui uma caixa com um tatu dentro, uma camisa do flamengo, sacos de estopa com roupas, documentos e dinheiro dentro de um saquinho na cueca ou na calcinha, além de um facão e um berimbau. Os mais preparados e bem de vida chegam também com um radinho AM, coisa rara no Nordeste. No Rio de Janeiro são conhecidos como Paraíba.

Entretanto, o grande salto para a tipificação do estigma baiano se faz através da musica Foge que é baiano, lançada de 2010 para 2011, na qual se podem ver alguns desses traços selecionados na percepção daquele que distinguiria e comporia a figura do "baiano",num continuum simbólico que consolidaria grande parte das variações das percepções individuais, como na fala de um entrevistado: "Essa musica diz TUDO, só quem tem vizinhos baianos sabe como é verdade!". Segue a letra da música:

[1] Todo pessoal da p-58, p-55.. Tamo Junto! Trabalho na "ingivix" sou encarregado ... melhor gato que tem, venha se aproxime...

[2] Eu bebo litrão da "Maínha" com os mano Xaveco traveco não to nem "ligano" Foge que é baiano, foge que é baiano...

[3] Churrasco segunda, vizinho "acordano" Eu curto a Ivete, o Naldo e o Caetano ... Foge que é baiano, foge que é baiano..

[4] Na festa eu tóco o terrô, só pique parangolé rebolation na Buarque, lá no Lads tem mulé encontrei uma encorpada que só podia por trás peituda do gogó grande, conheci na Silva Paes.

[5] De boombox no busão, gel, cabelo do Neymar Tem cavaco, tem tantan, viação noiva do mar

[6] Agora eu fiquei doce e é assim que eu sobrevivo To tirando onda no rolé de seletivo ...

[7] Se eu tiver boombox? FOGE QUE É BAIANO ... E loco de cerveja ? FOGE QUE É BAIANO ...

[8] Tem churrasco todo dia ? FOGE QUE É BAIANO ... Tem segunda e quarta-feira ? FOGE QUE É BAIANO ...

Desse modo, podemos ver na música que o ponto 1) faz referencias ao posto de trabalho ("encarregado") do "baiano", o 2) e o 4) dizem respeito a sexualidade promíscua do "baiano"; os pontos 3) e 6) falam da preferência musical assim como do volume das festas e o dia inoportuno de suas reuniões; no 5) aparece o modo de se vestir, a suposta religião ("noiva do mar").

A realidade social, no entanto, como lembra Becker (2008), não é uma só. É recortada em múltiplos espaços, níveis e dimensões. De modo que uma pessoa pode seguir corretamente as regras de um espaço e infringir as regras de outro. Do mesmo modo, dependendo do espaço em que os agentes estão situados, há uma variação no grau e intensidade na prática do estigma. Há diferenças no modo de perceber e interpretar o "baiano" relativas ao ponto de vista do agente, isto é, ao espaço em que se situa na estrutura social (BOURDIEU, 1990, p. 158). 
O estigma diz respeito a "expectativas normativas" (GOFFMAN, 1988). Seu princípio reside justamente em sua interrupção. Para Goffmann (1988), os ambientes sociais produzem rotinas e repetições. Os comportamentos e ações possíveis de se praticar em cada ambiente já estão, de certa forma, inscritos, apontados nele em estado potencial (BOURDIEU, 2011, p. 238-239). Daí podermos nos dar ao luxo de deslocar a atenção mental desses por menores enquanto o corpo educado garante a adequação às regras. É essa naturalidade (incorporação das regras do espaço social a um nível instintivo, portanto de estreita correspondência entre espaço objetivo e subjetivo) que faz de nós nativos.

Porém se em um restaurante entrar alguém seminu, dançando e entoando cantos esquisitos, rapidamente nos daremos conta de seu deslocamento: "é nesse ponto, provavelmente, que percebemos que durante todo o tempo estivemos fazendo algumas afirmativas em relação aquilo que o individuo que esta a nossa frente deveria ser." (GOFFMAN, 1988, p. 12) É a este alguém que Schultz chamou de "estrangeiro": aquele que ignora não só a linguagem do ambiente em que ingressa, mas o que está por trás dela, toda a história de sua criação que, em um nativo, é apreendido ao nível do instintivo, que nele se constitui numa segunda natureza. Para o estrangeiro,

o padrão cultural do grupo ao qual se aproxima não tem a autoridade de um testado sistema de receitas, e isto, se por nenhuma outra razão, pelo menos porque ele não compartilha da forte tradição histórica pela qual este tem sido formado. Certamente, do ponto de vista do estrangeiro, também a cultura do grupo aproximado tem sua história peculiar, e esta história é até mesmo acessível a ele. Porém ela nunca se tornou uma parte integrante de sua biografia, como foi a história de seu grupo de origem. (SCHULTZ, 2010, p. 122)

Podemos, desse modo, observar que os comportamentos desviantes que permitem as reações e operacionalização do estigma, podem ocorrer pela simples ignorância ou insuficiência do conhecimento superficial que se tem acerca das regras de comportamento social. Becker toma esse argumento em seu estudo sobre o desvio demonstrando como a maioria dos atos desviantes que recebem a classificação de outsiders são "não intencionais", no sentido de que

eles implicam uma ignorância da existência de regra, ou do fato de que ela é aplicável nesse caso (...). Mas é necessário explicar a falta de conhecimento. Como pode alguém saber que seu ato é impróprio? Pessoas profundamente envolvidas numa subcultura particular (como uma subcultura religiosa ou étnica) podem simplesmente não ter consciência de que nem todos agem "daquela maneira" e assim cometer uma impropriedade. Pode de fato haver essas áreas estruturadas de ignorância de regras particulares. (grifo meu) (BECKER, 2008, p. 36)

Nesse sentido o estigma "baiano" passou a ser não só um novo signo no universo simbólico do riograndino, mas um elemento atuante na constituição subjetiva dos agentes locais. Não é por acaso que iremos encontrar grandes investimentos na definição a respeito de si mesmo, da identidade riograndina ou gaúcha nesse meio tempo de confusão de identidades e reação ao estrangeiro.

\section{CONCLUSÕES}

O rótulo "baiano", com os estigmas que permitem seu reconhecimento enquanto desviante nas interações cotidianas, encontra-se reificado na realidade riograndina. Esse descolamento em representação, sua autoreferência, permite que os agentes operem a rotulação em diferentes ocasiões, de modo dedutivo, ajustando o termo às suas necessidades pontuais. Isso põem a questão da polissemia do termo, em que a parcela incompleta do conceito, sua porosidade, permite operar um ajustamento conforme necessidades pontuais.

0 estigma refere-se a uma representação, que aqui aparece sob a necessidade de sentido, de assimilação na teia de significados anteriormente dados na realidade riograndina. Portanto diz respeito a restauração das fraturas abertas nessa realidade em função da instalação do polo naval, da conservação daquela realidade que garante aos nativos os lucros simbólicos derivados de sua agência. 


\section{REFERÊNCIAS}

[1] Becker, Howard Saul. Outsiders: estudos de sociologia do desvio. Rio de Janeiro; Zahar, 2008.

[2] Berger, Peter e Luckmann, Thomas. A construção social da realidade: tratado de sociologia do conhecimento. Petrópolis, Vozes, 1976.

[3] Blanco, Cristina Fernandez et al. Migraciones: nuevas movilidades en un mundo en movimiento, Barcelona: Ed. Bilbao, 2006.

[4] Bourdieu, Pierre. O poder simbólico. (2011), 15ae ed. Rio de Janeiro: Bertand Brasil.

[5] . Coisas Ditas: Espaço social e poder simbólico. São Paulo: Brasiliense, 2004. 150-168 pp.

[6] Elias, Nobert e Scotson, John. Os estabelecidos e os outsiders: sociologia das relações de poder a partir de uma pequena comunidade. Rio de Janeiro: Zahar, 2000.

[7] De Sena, Angélica e Lisdero, Pedro. Etnografia virtual: aportes para su discusion y diseño, Buenos Aires, Fundación Cicus, 2014.

[8] Fabres, Ana Cristina Porto. Industria naval de Rio Grande: modelo de trabalhadores da base produtiva. Pelotas - RS, 2014.

[9] Goffman, Erving. Estigma: notas sobre a manipulação da identidade deteriorada, Rio de Janeiro; Ed. Guanabara, 1988.

[10] Secretaria Municipal de Coordenação e Planejamento. Plano Diretor do Polo Naval de Rio Grande, nº PL-FRRG01-DIS-001-0.

[11] Shutz, Alfred. O Estrangeiro: um ensaio em psicologia social. Revista Espaço Academico, no 113. Trad. Márcio Duarte e Michael Hanke, 2010. 


\section{Capítulo 12 \\ A igreja bipolar}

\section{Miriam Barbosa}

Resumo: 0 artigo tem como objetivo fazer um estudo sobre o transtorno psiquiátrico no Corpo de Cristo, descrevendo a origem, causa, e efeito do problema. A Bipolaridade é uma doença do século XXI, e têm crescido alarmante. Gera problemas maiores quando não é tratado adequadamente. Analisando um paralelo de ambos, e evidenciar que a doença que atinge a igreja de Cristo vem sendo atribuída da mudança de humor e juntamente com o pecado não confessado, e esgotamento mental de vários problemas de outrem. Assim, tornando uma igreja doente. 0 Objetivo geral é apresentar inicialmente a descrição da TB, suas causas, efeitos, a relação ao Corpo de Cristo, como ela tem entrado nos membros e Pastores das igrejas. Objetivo específico é analisar, como a igreja se tornou Bipolar, e se há cura. A metodologia aplicada, é descritiva, exploratória, bibliográfica, com estudo de casos, e dados estatísticos. A relevância dos resultados presentes poderá então servir de apoio às Congregações, onde o Pastor local poderá capacitar seus membros a ampara-los de forma certa, e direciona-los ao tratamento psiquiátrico corretamente, e ser pascentado adequadamente. Entretanto, a paciente precisa se adaptar com um novo estilo de vida e, para isso, precisa de um sistema de apoio não só familiar como também ministerial.

Palavras-chave: Bipolar; Corpo de Cristo; Doença; Medicina; Psiquiátrica. 


\section{INTRODUCCÃO}

0 transtorno Bipolar (TB) é uma oscilação entre os polos da euforia e da tristeza, passando por agressividade, apatia ou ansiedade. A TB é identificada pela Organização Mundial da Saúde (OMS) uma das principais causas da redução do tempo de vida e saúde na população entre 15 anos e 44 anos de idade, ultrapassando causas como guerra, violência e esquizofrenia. No Brasil o Transtorno Bipolar (TB) ataca $5,8 \%$ da população (11,5 milhões de pessoas)".

É originalmente chamado de "insanidade maníaco-depressiva", é uma condição psiquiátrica caracterizada por alterações graves de humor, que envolvem períodos de humor elevado e de depressão (polos opostos da experiência afetiva) intercalados por períodos de remissão, e estão associados a sintomas cognitivos, físicos e comportamentais específicos. 0 estudo apresenta inicialmente a descrição da TB, suas causas, efeitos, depois estuda a relação ao Corpo de Cristo, como ela tem entrado nos membros e Pastores das igrejas. Por fim, como a igreja se tornou Bipolar, e podemos cura-la? A metodologia aplicada, foi descritiva, exploratória, bibliográfica, com estudo de casos, e dados estatísticos.

Quando se pensa em TB, considera-se a causa, e efeito e a origem que a desencadeia na pessoa.

A relevância dos resultados presentes poderá então servir de apoio às Congregações, onde o Pastor local poderá capacitar seus membros a ampara-los de forma certa, e direciona-los ao tratamento psiquiátrico corretamente, e ser pascentado adequadamente. Entretanto, a paciente precisa se adaptar com um novo estilo de vida e, para isso, precisa de um sistema de apoio não só familiar como também ministerial.

A metodologia aplicada, é descritiva, exploratória, bibliográfica, com estudo de casos, além de dados estatísticos de órgão oficiais do Estado.

\section{HARMATIA}

A Igreja de Cristo têm apresentado sintomas adversos, baseado nos indicadores de esgotamento físico dentro de seus gabinetes pastorais. Agravando tais indicadores com os pecados não confessados. Dessa maneira, abrindo-se uma brecha na sua saúde, entrando a enfermidade em seus corpos, por meio do pecado (BIBLIA, Mt 5:14)

Hamartiologia, vem do grego transliterado hamartia = erro, pecado + logós = estudo, como sugere o próprio nome, é a ciência que estuda o pecado e as suas origens e consequências, ou - se preferível - o estudo sistematizado daquele tema (pecado). (FAFITEAL, 2011). Quer dizer: Errar o alvo, fracassar.

"Pecado é qualquer falta de conformidade, ativa ou passiva, com a lei moral de Deus. isso pode ser uma questão de ato, e pensamento ou disposição ou estado interior". (ERICKSON, 1992)

Pecado é rebelião e desobediência: segundo o manual de todo cristão, a Bíblia. Adão e Eva desobedeceram a ordem de Deus, foi expulso do Jardim do Éden, (BIBLIA, Gn 2.16,). E criando a identidade do pecado do homem. 0 pecado adâmico (de adão).

Por essa natureza caída, somos pecadores, "Porque todos pecaram e destituídos estão da glória de Deus" (BIBLIA, Romanos 3.23).

E Por consequência, houve a morte (BIBLIA, Gn 2.17), "no dia em que dela comeres, certamente morrerás".

"Mas, as vossas iniquidades fazem separação entre vós e o vosso Deus; e os vossos pecados encobrem o seu rosto de vós, para que não vos ouça." (BIBLIA, Isaias: 59).

\subsection{A FONTE DO PECADO}

A cada momento somos forçados a pecar, a natureza pecaminosa que atribuímos na queda de Adão, atiça a buscarmos o que é errado aos olhos de Deus. No Livro de Tiago, relata "Cada um, porém, é tentado pela própria cobiça, sendo por esta arrastada e seduzido. Então a cobiça, tendo engravidado, dá à luz o pecado; e o pecado, após ter-se consumado, gera a morte", (BIBLIA, Tiago 1.14-15).

Uma das consequências do pecado é a morte, veja no Livro de Romanos "o salário do pecado é a morte", no livro de Genesis 2.17 -"no dia em que dela comeres, certamente morrerás". (BIBLIA, Romanos 6: 23).

A Morte aqui descrita pode ser espiritual ou física, como está relatada no livro de João, na história do paralitico do Tanque de Betesda, cujo homem com 38 anos de idade, que sofria de uma enfermidade que era causada pelo pecado. 
Vejamos no versículo 14, mais tarde Jesus o encontrou no templo e lhe disse: "Olhe, você está curado. Não volte a pecar, para que algo pior não lhe aconteça", (BIBLIA,João 5:14)

É nítido que o pecado aprisiona o homem, traz enfermidades para o corpo físico, criando-se uma barreira na atmosférica espiritual, impedindo-se a oração ser ouvida pelo nosso Deus. Segundo o Profeta messiânico Isaias: "Mas as vossas iniquidades fazem separação entre vós e o vosso Deus; e os vossos pecados encobrem o seu rosto de vós, para que não vos ouça" Isaías 59:2 (BIBLIA, 2017).

Qualquer satisfação inconveniente de um desejo natural é "concupiscência da carne" 1 João 2.16. "Porque tudo o que há no mundo, a concupiscência da carne, a concupiscência dos olhos e a soberba da vida, não são do Pai, mas do mundo."

\subsection{CONSEQUÊNCIAS DO PECADO}

Desde no Antigo Testamento, Deus abomina o pecado, e não deixa impune quem o comete. Até mesmo Israel a "menina dos olhos D'Ele". Inúmeras vezes vemos que Deus a levou para as mãos dos seus inimigos, pelo pecado cometido.

Vejamos no Livro de 2 Crônicas capitulo 33, , cujo Rei Manassés, fez tudo que reprovava ao Senhor Deus, e a consequência do pecado relata no versículo 11 deste capitulo. "Por isso o Senhor enviou contra eles os comandantes do exército do rei da Assíria, os quais prenderam Manassés, colocaram-lhe um gancho no nariz e algemas de bronze, e o levaram para a Babilônia," (BIBLIA, 2017).

0 pecar é um ato deliberado de se voltar contra a Deus, literalmente se Rebelar-se contra o Senhor, é assinar sua própria CONDENAÇÃO, vejamos no Livro de Romanos, capítulo 8 versículo 1: "Portanto, agora nenhuma condenação há para os que estão em Cristo Jesus, que não andam segundo a carne, mas segundo o Espírito. (BIBLIA, 2017).

Também em Colossenses 1.21: "A vós também, que noutro tempo éreis estranhos, e inimigos no entendimento pelas vossas obras más, agora, contudo vos reconciliou". (BIBLIA, 2017)

De acordo em Salmos 51:12,13 (BIBLIA NVI, 2017): “Torna a dar-me a alegria da tua salvação, e sustémme com um espírito voluntário. Então ensinarei aos transgressores os teus caminhos, e os pecadores a ti se converterão."

A oração de Davi de arrependimento ao Senhor, após ter cometido o adultério com Bate-Seba, Davi perde a alegria, pois o pecado rouba a alegria, e com isso a tristeza entra no ser do Rei Davi.

E o *GRANFATALE, (*, expressão: grande fatal) é no livro de Tiago capítulo 4, versículo 4, que nos diz: "quem quiser ser amigo do mundo constitui-se inimigo de Deus". (BIBLIA NVI, 2017).

\section{A BIPOLARIDADE}

O transtorno bipolar é identificado pela Organização Mundial da Saúde (OMS) como uma das principais causas da redução do tempo de vida e saúde na população entre 15 anos e 44 anos de idade, ultrapassando causas como guerra, violência e esquizofrenia, (ABRATA, 2017). Segundo MORENO, (2017), Psiquiatra da Clinicas da Universidade Paulista de São Paulo (USP), confirma: No Brasil é a Transtorno Bipolar (TB) que ataca 5,8\% da população (11,5 milhões de pessoas)", segundo do hospital e 254 milhões no mundo inteiro das clinicas da USP.

A TB é originalmente chamada de "insanidade maníaco-depressiva", é uma condição psiquiátrica caracterizada por alterações graves de humor, que envolvem períodos de humor elevado e de depressão (polos opostos da experiência afetiva) intercalados por períodos de remissão, e estão associados a sintomas cognitivos, físicos e comportamentais específicos, (GOODWIN, 2012).

0 transtorno se diferencia em dois tipos principais: o Tipo I, em que a elevação do humor é grave e persiste (mania), e o Tipo II, em que a elevação do humor é mais branda hipomaníaco (MANUAL DIAGNÓSTICO E ESTATÍSTICO DE TRANSTORNOS MENTAIS 5a EDIÇÃO DO DSM 5)

Segundo Paulo Fernando Nicolau Psiquiátrico, descreve: “É um Episódio Hipomaníaco é definido como um período distinto, durante o qual existe um humor anormal e persistentemente elevado, expansivo ou irritável, com duração mínima de 4 dias. 0 período de humor anormal deve ser acompanhado por pelo menos três sintomas adicionais de uma lista que inclui auto-estima inflada ou grandiosidade (nãodelirante), necessidade de sono diminuída pressão por falar, fuga de idéias, distratibilidade, maior 
envolvimento em atividades dirigidas a objetivos ou a agitação psicomotora, e envolvimento excessivo em atividades prazerosas com um alto potencial para conseqüências dolorosas", (PSIQUIATRIANET, 2017).

Tradicionalmente designada Doença Maníaco-Depressiva, é uma doença psiquiátrica caracterizada por variações acentuadas do humor, com crises repetidas de depressão e mania. 0 nosso tipo de temperamento é o alicerce do nosso humor e, por consequência os possíveis transtornos de humor que sofremos também são compatíveis com nossos temperamentos.

Segundo a Associação de Apoio Depressivo e Bipolares (AADB), "qualquer dos dois tipos de crise pode predominar numa mesma pessoa sendo a sua frequência bastante variável. As crises podem ser graves, moderadas ou leves. As viragens do humor, num sentido ou noutro têm importante repercussão nas sensações, nas emoções, nas ideias e no comportamento da pessoa, com uma perda importante da saúde e da autonomia da personalidade."

\subsection{TEMPERAMENTO E HUMOR}

O temperamento que também conhecemos como "gênio", esta ligada a sensações e motivações básicas e automáticas da pessoa no âmbito emocional. É herdado geneticamente e regulado biologicamente e poder ser observado nos primeiros anos de vida. É Importante frisar que o nosso tipo de temperamento é o alicerce do nosso humor e, por consequência, os possíveis transtornos de humor que sofremos também são compatíveis com nosso temperamento. Assim pessoas com temperamento mais apimentado e dinâmico pode ter alterações de humor com franca agressividade ou euforia, o que seria mais raro em pessoas com temperamento brando e sereno. (LARA, 2009).

O Psicólogo Jung descobriu duas atitudes básicas no comportamento do homem que estão intrinsecamente ligadas ao temperamento. Estas atitudes são: introversão e extroversão. "Na Introversão incluem-se os melancólicos e fleumáticos. Na extroversão incluem-se os sanguíneos e coléricos." Introversão e extroversão são ambas as atitudes normais. A introversão em grau elevado torna-se patológico, da mesma forma que a extroversão excessiva também será característica de estado mórbido, (JUNG, 1971).

Silveira apontou, ainda: "não só o homem comum pode ser enquadrado numa dessas duas atitudes típicas. Igualmente os filósofos, através de suas concepções do mundo revelam seus tipos psicológicos, bem como os artistas, através de suas interpretações da vida. Jung se intrigava que os mesmos fenômenos psíquicos fossem vistos e compreendidos tão diferentemente por homens de ciência, cada um de seu lado, honestamente convencido de haver descoberto a verdade única." (SILVEIRA, 1988)

O Livro de 1 Timóteo 3: 2-3, (BIBLIA,2017), relata como deve ser o BISPO: “Um bispo deve, portanto, ser irrepreensível, o marido de uma única mulher, sóbrio, prudente, de comportamento decente, hospitaleiro, digno de ensinar, não ser dado a beber, nem brigão, mas gentil, não controverso, nem ganancioso",

Esse temperamento é chamado para JUNG, extroversão e sanguíneo, que pode levar ao grau patológico. Nota-se o cuidado ao escolher um HOMEM PARA OBRA DO SERNHOR!

\subsection{TEMPERAMENTO INFLUENCIADO POR DEMÔNIO}

No livro de 1 Samuel 19: 9-10 (BIBLIA -NVI, 2017), relata o Temperamento, influenciado por espirito maligno.

"E veio um espírito maligno do Senhor sobre Saul; e ele estava sentado em sua casa com a lança na mão enquanto David tocava harpa. E Saul tentou esgueirar Davi para a parede com a lança, mas escapou do rosto de Saul, e a lança presa à parede; David fugiu e escapou naquela noite."

Com base de Jung, Silveira e a Própria Bíblia, me reforça que o temperamento, pode ser influenciado tanto espirito maligno, quanto ao Espirito Santo. Vence quem alimenta o espirito, com a Palavra de Deus e jejuando. 


\section{RELATO DE BIPOLARIDADE TIPO 1 (DIOGO LARA - MÉDICO PSIQUIÁTRICO)}

\section{Caso 1}

Dois pacientes que manifestavam o estado maníaco na sua plenitude marcaram muito meu primeiro ano de psiquiatria. Um tinha 18 anos e foi internado por condutas de extremo risco. Ele julgava ser o diretor e ator principal de um filme de aventura que acontecia 24 horas por dia, sendo filmado todo o tempo de lugares escondidos, ou seja, estava psicótico. Antes de ser trazidos para a unidade de internação, tinha passado algumas horas surfando em cima de caminhões, em grandes "cenas de ação". Quando havia oportunidade, pulava de um caminhão para outro, como nos filmes em que lutas incríveis são travadas em cima de vagões de trem.

Tinha cabelos compridos, era bonito, absurdamente carismático e o êxtase que vivenciava era transbordante e contamina outros pacientes e os funcionários. Ao encontrar uma médica-sedente, dizia que ela seria a estrela principal de seu filme, olhando-a fixamente, com um sorriso vigarista e generoso. Com certa frequência, as residentes me relatavam coisas que ele tinha feito ou dito. Nenhuma conseguia esconder uma ponta de vaidade por ter sido escolhida a atriz principal do suposto filme. Finalmente, em uma reunião clinica entre todos os residentes acabou ficando caro, para frustração geral da ala feminina, que havia várias atrizes principais para o filme (e dezenas de filmes, aliás), entre médicas, enfermeiras, auxiliares e pacientes. Ele era uma mistura do protagonista de Don Juan de Marco ( Johnny Depp) e da situação do filme 0 Show da Trumann ( Jim Carrey).

Sua evolução durante a internação não foi muito favorável. Respondeu pouco à combinação de medicação para a fase maníaca com sintomas psicóticos. Optamos por sessões de eletroconvulsoterapia, um procedimento reservado atualmente apenas para os casos refratários. Teve melhor significativa e recebeu alta. 0 acompanhamento ambulatorial começou bem, mas logo passou a ser o mais errático - ele deixou de tomar a medicação como deveria, até largar o tratamento. Anos mais tarde, encontrei-o por acaso, quando passeava pela rua à noite com um amigo, francamente eufórico. Em outra ocasião, encontrei-o melhor, e ele me contou que havia sido internado outras quatro vezes por episódios maníacos, sempre no verão. Ainda assim, não tomava os remédios como deveria, embora todos os anos, na primavera, começasse a achar que era hora de passar a tomar a medicação corretamente. Ainda levará um tempo até que consiga andar bem com os patins da bipolaridade.

\section{IGREJA X DEPRESSÃO}

“[...] conflitos externos e temores internos. Deus porém consolou-nos com a chegada de Tito" (II Co 7.5,6)

A bipolaridade esta crescendo entre os Pastores (Igreja), a doença sinaliza, mas quando o sinal é ignorado, o suicídio chega, e sem pena abraça-os, sem dizer adeus para alguém.

A Bíblia relata em 1 Reis 19:9,10: "E ali entrou numa caverna e passou ali a noite; e eis que a palavra do Senhor veio a ele, e lhe disse: Que fazes aqui Elias?

"E ele disse: Tenho sido muito zeloso pelo Senhor Deus dos Exércitos, porque os filhos de Israel deixaram a tua aliança, derrubaram os teus altares, e mataram os teus profetas à espada, e só eu fiquei, e buscam a minha vida para ma tirarem.".

Nota-se Elias ficou com medo, e depressivo, ao saber que Jezabel mataria ele, conforme aos profetas mortos por ela. Por esse motivo, entrou na caverna, escondendo de Jezabel.

De acordo com o teólogo cristão evangélico americano, filósofo e pastor. "Os $70 \%$ dos pastores lutam constantemente contra a depressão, $71 \%$ se dizem esgotados, $80 \%$ acreditam que o ministério pastoral afetou negativamente suas famílias e 70\% dizem não ter um amigo próximo", (SCHAEFFER, 1984).

A igreja se tornou bipolar no momento que virou OSCILANTE, nos pecados cometidos (euforia) e não confessados (tristeza), esgotamento físico ( agressividade no seu espirito), apatia ( problemas dentro da família), ansiedade ( sem amizades). 
Grafico1 Áreas atingidas pela depressão, segundo

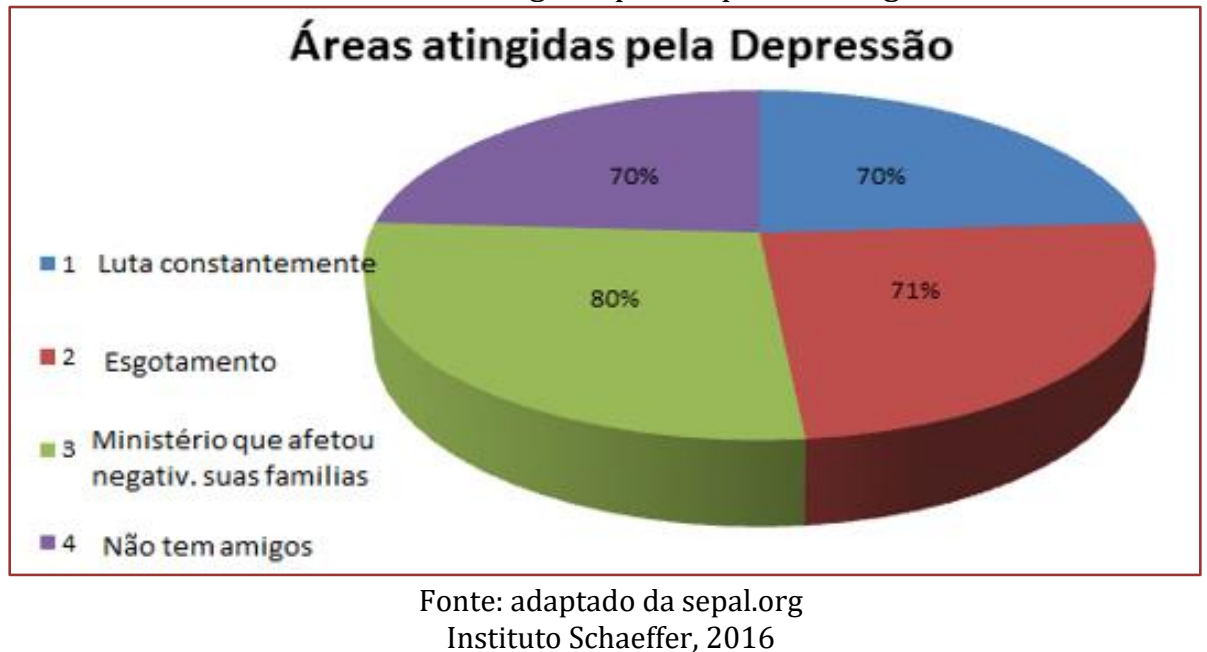

No Gráfico 1, as áreas atingidas pela depressão, os números de porcentagem, é calcula de 100 lutas, 70\% são atingidas. De 100 esgotamentos, 71\% são acometidas, de 100 ministério afetado negativamente suas famílias, $80 \%$ foram atingidas, e por fim, e $70 \%$ por falta de amigos.

"A causa mais comum noticiada para o suicídio de pastores e líderes, é a depressão associada a esgotamento físico e emocional, traições ministeriais, baixos salários e isolamento por falta de amigos," (SEPAL, 2016).

Boa parte está cansada, desanimada, chateada com a igreja e com a liderança. Muitos possuem dificuldades no cuidado com a família e as finanças de alguns estão desequilibradas. Isso acontece, em parte, porque pastores contemporâneos são cobrados como executivos ou técnicos de clubes de futebol, que precisam oferecer resultados numéricos às suas instituições. Caso contrário perdem seus membros, emprego, salário, moradia e sustento da família. É uma pressão enorme sobre os ombros de um ser humano. (SEPAL,2016)

No Livro de 2 Tm 4:13, relata-se: Quando vieres, traze-me a capa que deixei em Trôade, na casa de Carpo, e os livros, principalmente os pergaminhos (BIBLIA, 2017).

Versículo acima, demostra o problema encontrado, e a solução foi a chegada de Tito, onde o Apostolo precisava de um amigo, pois o desgaste emocional e físico já estavam acarretando em uma depressão. E se Deus não intervisse não saberíamos o que aconteceria, não é mesmo!

Como diz o Ed René Kivitz ${ }^{33}$ : "pessoas precisam de Deus, mas pessoas também precisam de pessoas". Foi "a chegada de Tito" que consolou o apóstolo Paulo, e era Marcos, acima da capa e dos livros, que teria mais utilidade.

Em um relatório da (OMS) Organização Mundial de Saúde sobre depressão serviu de gancho para textos na imprensa que colocavam o Brasil como amargando a maior prevalência da doença na América Latina. De acordo com os números, é isso mesmo. Temos $5,8 \%$ da população $(11,5$ milhões de pessoas) com depressão, o maior índice entre nossos hermanos. Nas Américas, estamos atrás somente dos Estados Unidos, que registram um pouco mais: 5,9\%.

Um dos pontos que explicam a prevalência aumentada em relação a outros países é a provável eficiência de nossos registros e diagnósticos. "Com todas as críticas que possamos ter ao SUS, ele nos dá acesso a dados de toda a população", diz Moreno. A informação e o maior preparo dos profissionais para encaminhar pessoas ao tratamento também aumentaram nos últimos anos e podem explicar a prevalência. Todo esse cenário ajuda a entender outra estatística apresentada pelo relatório: o maior número de casos na região Sul do Brasil. (MORENO, 2009) ${ }^{34}$,

\footnotetext{
33 Teólogo, escritor, e idealizador do Fórum Cristão de Profissionais.

34 Ricardo A. Moreno - Diretor Programa de Transtornos Afetivos do Instituto e Departamento de Psiquiatria do Hospital das Clínicas da USP
} 
Se mesmo o documento da OMS aponta que o acesso ao tratamento é uma dificuldade (em muitos países, menos de $10 \%$ dos doentes recebem terapia), é sensato dizer que em muitos lugares a prevalência da depressão seria bem maior se mais pessoas fossem tratadas.

\section{A CURA}

A Redenção e a Justificação são parâmetros, para que a cura sobrevém sobre a alma doente, que necessita do remédio. 0 sangue de Jesus é o fator que liga esse parâmetro, e o remédio se torna visível. Mas, o doente, precisa confessar os seus pecados, deixa-los, para atingir a cura. A cura traz alivio para alma, e assim o corpo fica sarado. Outro parâmetro para a cura da alma é a Mente renovada em Cristo, trás cura para o corpo doente.

A Redenção tem como objetivo de perdão dos pecados, por meio do Sangue de Jesus, como relata no livro de Efésios 1:7: "Nele temos a redenção por meio de seu sangue, o perdão dos pecados, de acordo com as riquezas da graça de Deus". (BIBLIA, 2017)

Em Romanos 5:17, relata: "Se pela transgressão de um só a morte reinou por meio dele, muito mais aqueles que recebem de Deus a imensa provisão da graça e a dádiva da justiça reinarão em vida por meio de um único homem, Jesus Cristo", (BIBLIA, 2017).

A Lei do Senhor é pra ser cumprida, quando há uma violação, chamamos de transgressão. Foi o que aconteceu com Adão e Eva, transgrediu uma ordem dada no Jardim do Éden, ( Não comer da arvore do conhecimento).

No Livro de Apocalipse 5: 9,10: "E cantavam um novo cântico, dizendo: Digno és de tomar o livro, e de abrir os seus selos; porque foste morto, e com o teu sangue nos compraste para Deus de toda a tribo, e língua, e povo, e nação; E para o nosso Deus nos fizeste reis e sacerdotes; e reinaremos sobre a terra" (BIBLIA,2017).

Somente o sangue de Jesus, que comprou-nos para Deus, e como vitória nos fez sacerdote, para reina sobre a terra. Jesus Cristo é a salvação para a nossa alma, é o único caminho e redenção dos pecados.

A Renovação da Mente, trás cura, pois é Jesus que renova a mente, e a mente onde habita Jesus, que é a verdade, não haverá lugar, para o inimigo de nossas almas trabalhar enganosamente e induzir a pecar, abrindo brechas, e trazendo enfermidades para o corpo. Jesus é a blindagem da mente. No livro de Efésios, no capitulo 6 versículo 17, relata uma da armadura de Deus para a guerra espiritual é o capacete da salvação, o qual nos blinda das setas do diabo a nossa mente. (BIBLIA, 2017)

No Livro de Romanos 12:2, relata: "E não vos conformeis a este mundo, mas transformai-vos pela renovação da vossa mente, para que experimenteis qual seja a boa, agradável, e perfeita vontade de Deus", ( BIBLIA, 2017)

Jesus convida os oprimidos de almas, no Livro de Mateus 11:28: "Vinde a mim todos os que estais cansados e oprimidos (doentes de alma) que eu vos aliviarei e encontrareis saúde para vossas almas". (BIBLIA, 2017).

No pós - diagnostico da igreja bipolar, é necessário, um acompanhamento médico, pois afeta também seu nível de energia, julgamento, memória, concentração, apetite, sono, desejo sexual e autoestima. Além disso, o transtorno bipolar tem sido associado à ansiedade, ao abuso de substâncias e a problemas de saúde como diabetes, doenças cardíacas, enxaqueca e pressão arterial elevada.

É melhor trabalhar com um psiquiatra experiente. 0 transtorno bipolar é uma condição complexa. 0 diagnóstico pode ser complicado e o tratamento é muitas vezes difícil. Por razões de segurança, a medicação deve ser acompanhada de perto. Um psiquiatra especializado em tratamento de transtorno bipolar pode ajudá-lo a navegar por esses mares revoltos.

É preciso tomar direito os remédios prescritos pelo psiquiátrico, para poder equilibrar o alto e baixo do humor. Pode-se ajudar a Igreja bipolar a controlar os sintomas fazendo exercícios regularmente, dormindo o suficiente, comendo direito, monitorando seu estado de espírito, mantendo o estresse em nível mínimo e cercando-se de pessoas que o apoiam. A terapia e estratégias de autoajuda também desempenham papéis importantes.

0 transtorno bipolar requer tratamento de longo prazo. Uma vez que ele é uma doença crônica e com recidivas, é importante continuar o tratamento mesmo quando você está se sentindo melhor. A maioria das pessoas com transtorno bipolar precisa de medicação para prevenir novos episódios e ficar livre dos sintomas, (REVISTA OASIS AGOSTO, 2014). 
Entretanto, a igreja diagnosticada com a Bipolaridade precisa se adaptar com um novo estilo de vida e, para isso, precisa de um sistema de apoio não só familiar como também ministerial.

\section{DISCUSSÃO E RESULTADO}

As análises dos estudos corroboram para identificar o problema da Bipolaridade igreja de Cristo. Descobrimos (Gráfico 1) que o pecado é a causa introdutória da enfermidade no corpo físico, consequentemente o transtorno bipolar, mas há causas secundárias proveniente ao esgotamento (físico e espiritual), e lutas constantemente (espiritual), falta de amigos, e ministério que afetou negativamente as famílias.

Na análise do temperamento (gênio), segundo psicólogo JUNG, (1971), descobrimos que ela esta ligada as sensações e motivações e automáticas da pessoa no âmbito emocional, e herdada geneticamente e regulado biologicamente. O Psicólogo Jung descobriu duas atitudes básicas no comportamento do homem que estão intrinsecamente ligadas ao temperamento.

Na análise espiritual, a Bíblia traz base em diferentes passagens que reforça que o temperamento pode ser influenciado pelo demônio, trazendo a si uma alteração no temperamento do influenciado. No livro de 1 Samuel 19: 9-10 (BIBLIA -NVI, 2017), relata o temperamento e o comportamento, influenciado por espirito maligno.

"E veio um espírito maligno do Senhor sobre Saul; e ele estava sentado em sua casa com a lança na mão enquanto David tocava harpa. E Saul tentou esgueirar Davi para a parede com a lança, mas escapou do rosto de Saul, e a lança presa à parede; David fugiu e escapou naquela noite," ( BIBLIA, 2017)

Na análise da depressão, descobrimos que Elias pode ter sido acometido Tipo II, em que a elevação do humor é mais branda hipomaníaco da bipolaridade; MEDO E DEPRESSIVO ao saber que Jezabel mataria ele, conforme aos profetas mortos por ela. Por esse motivo, entrou na caverna, escondendo de Jezabel. Em 1 Reis 19:9,10, "E ali entrou numa caverna e passou ali a noite; e eis que a palavra do Senhor veio a ele, e lhe disse: Que fazes aqui Elias? (BIBLIA, 2017). Elias ficou

Na Análise da Depressão, descobrimos o suicídios de Pastores e Líderes em relação aos Pastores e Líderes:

“A causa mais comum noticiada para o suicídio de pastores e líderes, é a depressão associada a esgotamento físico e esgotamento físico e emocional, traições ministeriais, baixos salários e isolamento por falta de amigos," (SEPAL, 2016).

$\mathrm{Na}$ análise de amizades, que corrobora com a bipolaridade, o caso do Apostolo que necessitava de Tito (Livro de 2 Tm 4:13), demostra o problema encontrado, e a solução foi a chegada de Tito, onde o Apostolo precisava de um amigo, pois o desgaste emocional e físico já estavam acarretando em uma depressão. E se Deus não intervisse não saberíamos o que aconteceria, não é mesmo!

Na Análise da cura da Igreja Bipolar, descobrimos que A Redenção e a Justificação são parâmetros, para que a cura sobrevém sobre a alma doente, que necessita do remédio. 0 sangue de Jesus é o fator que liga esse parâmetro, e o remédio se torna visível. Mas, o doente, precisa confessar os seus pecados, deixa-los, para atingir a cura. A cura traz alivio para alma, e assim o corpo fica sarado. Outro parâmetro para a cura da alma é a Mente renovada em Cristo, trás cura para o corpo doente.

E a renovação da mente traz cura, pois é Jesus que renova a mente, e a mente onde habita Jesus, que é a verdade, não haverá lugar, para o inimigo de nossas almas trabalhar enganosamente e induzir a pecar, abrindo brechas, e trazendo enfermidades para o corpo. Jesus é a blindagem da mente.

No livro de Efésios, no capitulo 6 versículo 17, relata uma da armadura de Deus para a guerra espiritual é o capacete da salvação, o qual nos blinda das setas do diabo a nossa mente. (BIBLIA, 2017)

Na Análise pós diagnóstico, descobrimos que precisa-se ter um acompanhamento psiquiátrico, tomar os remédios prescritos. Entretanto, a paciente precisa se adaptar com um novo estilo de vida e, para isso, precisa de um sistema de apoio não só familiar como também ministerial.

$\mathrm{Na}$ análise de como a igreja se tornou bipolar no momento que virou OSCILANTE, nos pecados cometidos (euforia) e não confessados (tristeza), esgotamento físico ( agressividade no seu espirito), apatia ( problemas dentro da família), ansiedade ( sem amizades). 
Consideramos o artigo estudado, um estudo necessário para a Igreja atual, que luta tanto, no físico e no campo espiritual. 0 esgotamento psíquico tem levado Pastores e Lideres ao suicídio por não cuidar da sua saúde. Além de vemos casos na bíblia de Homens de Deus que sofreram desse transtorno, que ainda não era assim chamado. Como a igreja se tornou Bipolar, e podemos cura-la? Apesar desse critério, a medicina mostrou outras portas para diferenciar as causas

Além de entendermos que o descontrole do humor pode se um catalisador de demônio e influenciar o comportamento da pessoa que sofre a Bipolaridade. Por isso que logo diagnosticado, é bom seguir as prescrições do psiquiátrico, e tomar os remédios, e é fundamental ter apoio familiar.

\section{REFERÊNCIA}

[1] A Biblia, 2017

[2] Adeb. Associação de Apoio aos doentes depressivos e Bipolares Disponível em: >>http://www.adeb.pt/pages/o-que-e-a-doenca-bipolar. Acesso em :>> 13 Julho 2017

[3] Anderson IM, H. P. S. J., 2012.

[4] APA. Manual Diagnóstico e Estatístico de Transtornos Mentais. 5a ed. Porto Alegre: Artmed; 2014.

[5] Biblia Knowing Jesus . Temperamentos Disponível em: > https://bible.knowingjesus.com/Espa\%C3\%B1al/topics/Temperamento Acesso em: >> 15 Out. 2017

[6] Brasil . Transtorno bipolar mania hipomania e depressão Disponível em >>https://www.brasil247.com/pt/247/revista_oasis/149117/Transtorno-bipolar-mania-hipomania-edepress\%C3\%A3o-bipolar.htm >> acesso em: 6 Dez. 2017

[7] Brasileiros. Pessoas mais Depressivas no Brasil Disponível em:>> http://brasileiros.com.br/2017/03/pessoas-sao-mais-depressivas-no-brasil/ >> Acesso em: 13 Julho 2017

[8] Goodwin GM. Bipolar disorder. Medicine. 2012;40:596-8.

[9] Harmatiologia. Matéria Teologica Disponível em: >> http://mensagenspoderosas.webnode.com.br/news/harmatiologia-materia-teologica/ Disponível em https://www.bibliaonline.com.br

[10] Jung. Tipos psicológicosDisponível em: >> http://www.jung-rj.com.br/artigos/tipos_psicologicos.htm Acesso em:>>15 Out. 2017

[11] Lara,Diogo, Temperamento forte e bipolaridade: dominando o altos e baixos do humor-10Ed. São Paulo: Saraiva, 2009

[12] Psiquiatria Geral. Humor Disponível em: >> http://www.psiquiatriageral.com.br/humor/eh04.htm Acesso em:>> 15 de Outubro de 2017

[13] Sepal. Suicídio de Pastores e líderes uma reflexão necessária Disponível em: >>http://sepal.org.br/blogsepal/suicidio-de-pastores-e-lideres-uma-reflexao-necessaria/ Acesso em :>> 19 de Julho de 2017

[14] Usp. Universidade Paulista de São Paulo Disponível em:

>>http://www.usp.br/espacoaberto/arquivo/2008/espaco92jun/0comportamento1.htm Acesso em: 06 Dez.2017

Disponível em: http://www.usp.br/espacoaberto/?p=6616>> Acesso em: 6 Dez.2017 


\section{Capítulo 13}

\section{Direito ao esquecimento: Balanço entre Brasil e Espanha}

\section{Anna Lúcia Noschang da Silva \\ Valéria Ribas do Nascimento}

Resumo: 0 trabalho abordará o tema do direito ao esquecimento em uma análise comparativa dos julgados da justiça brasileira frente à justiça espanhola, na intenção de se analisar a tutela dos direitos fundamentais já garantidos no direito pátrio em virtude dos avanços vividos na sociedade atual. A hipótese será enfrentada através da conceituação dos direitos fundamentais na legislação brasileira, inclusive através de um viés histórico, a fim de se detectar a emergência de novos direitos, que, neste trabalho será o direito ao esquecimento, o qual emerge da tutela dos direitos fundamentais da intimidade, privacidade, imagem e honra, que aqui, entra em rota de colisão com outros direitos fundamentais, também garantidos constitucionalmente, tais como direitos relacionados à liberdade de manifestação de pensamento e de informação. Com isso, será realizada uma análise de casos brasileiros e espanhóis a fim de traçar um paralelo de como jurisdições distintas enfrentam a temática deste novo direito emergente. Desse modo, tentar-se-á concluir a natureza jurídica, a forma de tutela do direito supramencionado e a melhor solução para a resolução de conflitos que possam surgir envolvendo a temática aqui abordada. Para abordagem do tema, utilizou-se do método procedimental dialético, posto que foi realizado um embate de ideais conflitantes a fim de averiguar as dissonâncias da Justiça Espanhola para Brasileira no que concerne ao direito ao esquecimento. 0 artigo se enquadra no eixo temático "Direitos Fundamentais e Políticas Públicas”.

Palavras-chave: direito ao esquecimento; direitos fundamentais; jurisprudência; novos direitos; natureza jurídica. 


\section{CONSIDERAÇÕES INICIAIS}

No mundo em que vivemos, é instantânea a troca de todo e qualquer tipo de dados e informações, novas ou antigas, especialmente via internet, fato que nos coloca imbuídos em uma sociedade em rede. Diante deste cenário, os direitos fundamentais de intimidade, vida privada, honra e imagem (art.5o, X CF) estão constantemente em conflito com os direitos relacionados à liberdade de manifestação de pensamento (art. 5으, IV CF) e de informação (art.5ํ, XIV e art.220 CF).

Partindo da premissa de entendimento acerca da sociedade em rede que Manuel Castells constrói, esta sociedade pode ser entendida como uma trama de relações de diferentes formas, tais como, familiar, étnica, econômica, profissional, social, religiosa e política, que se desenrolam a partir do uso das tecnologias da informação e da comunicação.

A referida sociedade em rede é regida pela primazia da morfologia social sobre a ação social. Importante definir também a concepção de redes que aquele Autor traz, como sendo um "conjunto de nós interconectados e o nó sendo um ponto no qual uma curva se entrecorta" (CASTELLS, 2005, p. 566). Basicamente o que um nó é depende do tipo de redes concretas que se está a analisar.

Uma estrutura social com base em redes é um sistema aberto altamente dinâmico suscetível de inovação sem ameaças ao seu equilíbrio. De acordo com o referido Autor, redes são instrumentos apropriados para a economia capitalista baseada na inovação, globalização e concentração descentralizada.

A complexidade ao cenário jurídico atual faz com que seja urgente a adequação da legislação na tutela dos direitos já garantidos, uma vez que o convívio através dos "nós" citados por Castells proporcionam um aceleramento desenfreado de novos relacionamentos. A partir disso podemos falar na criação de novos direitos na intenção de proteger os já tipificados, como é o caso do direito ao esquecimento, que viria para proteger outros direitos fundamentais.

Assim, neste trabalho será enfrentada a possibilidade de criação do direito ao esquecimento como um direito fundamental na intenção de garantia dos direitos que já se encontram postos no texto constitucional brasileiro vigente.

A fim de se evidenciar a necessidade acima referida, abordar-se-á o tema a partir dos impactos gerados nos direitos fundamentais ocasionados pelo fato de que hoje vive-se em uma sociedade em rede, bem como analisando um comparativo de julgados da Espanha e do Brasil na intenção de firmar o entendimento final defendido neste trabalho.

\section{DIREITOS FUNDAMENTAIS}

\subsection{IMPACTO DOS DIREITOS FUNDAMENTAIS GERADA PELA SOCIEDADE EM REDE}

Os direitos fundamentais estão inseridos em um gênero que engloba os direitos e garantias individuais, os direitos coletivos, os direitos sociais, os direitos de nacionalidade e os direitos políticos. Sendo fundamentais, estão intimamente relacionados aos seres humanos.

Todos esses direitos estão previstos na Constituição Federal, especialmente concentrados no art. 5o , cujo parágrafo primeiro consagra uma regra geral que determina que as normas definidoras dos direitos e garantias fundamentais têm aplicação imediata, apesar de não ser esta a realidade, posto que muitas vezes falta lei regulamentadora. Como exemplo, pode-se citar a greve dos trabalhadores, que é um direito previsto constitucionalmente, mas que ainda não está devidamente regulamentado.

0 presente trabalho será voltado aos direitos fundamentais individuais, que, como será visto, também são encontrados fora do campo constitucional, considerando que o Brasil adota um regime jurídico aberto, ou seja, que além de ser fundado em regras, também admite a utilização de princípios para a solução de controvérsias. Portanto, também existem direitos fundamentais que estão implícitos na $\mathrm{CF}$, ou fora dela, e que poderão ser assegurados, desde que estejam relacionados ao regime ou aos princípios por ela adotados 35

Ou seja, os direitos fundamentais não se restringem unicamente ao art.5o, podendo ser encontrados ao longo do texto constitucional, expressos ou decorrentes do regime e dos princípios adotados pela

${ }^{35}$ Art. 5ํㅡ, § 2o Os direitos e garantias expressos nesta Constituição não excluem outros decorrentes do regime e dos princípios por ela adotados, ou dos tratados internacionais em que a República Federativa do Brasil seja parte. 
Constituição Federal, ou, ainda, decorrentes dos tratados e convenções internacionais de que o Brasil seja parte(LENZA, 2014, p.1055).

Brevemente, a fim de melhor enfrentar a problemática proposta, é importante que haja a diferenciação entre direitos e garantias fundamentais. De acordo com J.J. Gomes Canotilho:

Rigorosamente, as clássicas garantias são também direitos, embora muitas vezes se salientasse nelas o caráter instrumental de proteção dos direitos. As garantias traduziam-se, quer no direito dos cidadãos a exigir dos poderes públicos a proteção de seus direitos, quer no reconhecimento de meios processuais adequados a esta finalidade (ex: direito de acesso aos tribunais para defesa de direitos, princípios do nullumcrimemsine lege e nullapoenasinecrimen, direito de habeas corpus, princípio do non bis in idem). (CANOTILHO, J.J. Gomes, 2000, p.390).

Dessa forma, direitos são bens e vantagens prescritos na norma constitucional, enquanto que as garantias são os instrumentos através dos quais se assegura o exercício dos aludidos direitos, ou prontamente os repara, caso violados (LENZA, 2014. p.671).

Antes de analisar o tema proposto, impende-se uma breve análise dos direitos fundamentais, a partir de um viés histórico, bem como de seus conceitos. Os referidos direitos fundamentais já percorreram um longo caminho de evolução, constante ao longo dos anos, sendo que a doutrina, dentre vários critérios, tradicionalmente costuma classificá-los como "gerações de direitos fundamentais", ou, segundo doutrina mais moderna, "dimensão de direitos fundamentais".

\subsection{DIMENSÕES DOS DIREITOS FUNDAMENTAIS ATRAVÉS DE UMA PERSPECTIVA HISTÓRICA NO ORDENAMENTO JURÍDICO BRASILEIRO}

Primeiramente, acerca da nomenclatura, é importante esclarecer que a acepção "gerações" traz a ideia de que uma geração estaria superando a outra, enquanto, na realidade, não é o que ocorre, pois uma geração de direitos fundamentais é somada à outra. Nada se perde. Por isso o termo "dimensões de direitos fundamentais" é o mais adequado, pois não transmite uma ideia de superação.

A referida soma de direitos está assegurada pelo efeito "cliquet" dos direitos, que se traduz em uma garantia de que os direitos não podem retroceder, só podendo avançar nas proteções dos sujeitos. No nosso país, esse efeito é mais conhecido como Princípio da Vedação do Retrocesso, ou seja, os direitos só podem progredir, jamais retroceder. Tal princípio engloba o tema do presente trabalho, uma vez que a criação do direito ao esquecimento, além de ser um direito a mais, servirá para garantia dos direitos e garantias fundamentais já existentes, conforme poderá ser verificado no corpo desta produção.

Segundo Canotilho, o referido princípio traduz a ideia de que é inconstitucional qualquer medida tendente a revogar os direitos já regulamentados, sem a criação de outros meios alternativos capazes de compensar a anulação desses benefícios (CANOTILHO, J. J. Gomes, 2002, p. 336).

Brevemente, os direitos fundamentais de primeira dimensão são aqueles direitos civis, que surgiram a partir do século XVII, ligados às liberdades públicas e aos direitos políticos que traduzem valores de liberdade - direitos de liberdade, posto que surgiram para impor limites ao poder do Estado Absolutista, em um momento em que o povo se encontrava desamparado.

Posteriormente, no século XIX, nasceram os direitos de segunda dimensão, que são aqueles relacionados aos direitos sociais, culturais e econômicos e correspondem ao direito de igualdade, pois surgiram em meio à Revolução Industrial.

Concomitantemente, em um momento em que o ser humano se viu inserido em uma coletividade, nasceram os direitos de terceira geração, que estão ligados aos novos problemas, relacionados à alteração e evolução da sociedade, tais como os direitos relacionados à preservação ambiental e os direitos relacionados aos consumidores - os chamados direitos de solidariedade.

Os direitos de quarta geração decorrem dos avanços no campo da engenharia genética, ao passo que essa tem potencial para colocar em risco a própria existência humana, através da manipulação do patrimônio genético.

Paulo Bonavides afirma que "a globalização política na esfera da normatividade jurídica introduz os direitos de quarta dimensão, que, aliás, correspondem à derradeira fase de institucionalização do Estado 
Social, destacando-se os direitos à democracia (direta), informação e pluralismo" (BONAVIDES, Paulo. P.569).

Sobre o assunto, Ingo Sarlet afirma:

"A proposta do Prof. Bonavides, comparada com as posições que arrolam os direitos contra a manipulação genética, mudança de sexo, etc., como integrando a quarta geração, oferece nítida vantagem de constituir, de fato, uma nova fase no reconhecimento dos direitos fundamentais, qualitativamente diversa das anteriores, já que não sei cuida apenas de vestir com roupagem nova reivindicações deduzidas, em sua maior parte, dos clássicos direitos de liberdade" (SARLET, 2015, p. 51).

Por fim, há autores, como Kant, que classificam a paz perpétua, ainda não alcançada, como sendo um direito fundamental de quinta geração de direitos fundamentais.

\section{NOVOS DIREITOS}

\subsection{DIREITO AO ESQUECIMENTO}

Com a ideia dos direitos fundamentais e sua evolução histórica já delineada, surge a problemática do conceito e da natureza jurídica do direito ao esquecimento, ainda não positivado.

Para fins de esclarecimento, é válido lembrar que os direitos fundamentais são aqueles previstos na Constituição Federal e que são aplicados nas relações públicas. Ou seja, nas relações entre Estado e indivíduo. Essa é chamada pelos estudiosos de "Eficácia Vertical dos Direitos Fundamentais". Vertical justamente porque é entre Estado e indivíduo - que são desiguais.

Já os direitos de personalidade, tais como imagem, honra, intimidade e vida privada são aqueles previstos na Constituição Federal e também no Código Civil, e são aplicados nas relações privadas, ou seja, nas relações entre indivíduos ou entes privados. Esta é a chamada "Eficácia Horizontal dos Direitos Fundamentais", cuja aplicação é cada vez mais crescente. Horizontal justamente porque é entre iguais não envolve o Estado.

Assim, há a chamada "cláusula geral dos Direitos de Personalidade", que se traduz em uma norma que assegura os referidos direitos de personalidade como um todo, sendo uma cláusula aberta. Essa cláusula está amparada pela Dignidade da Pessoa Humana, que é um dos fundamentos da República Federativa do Brasil, de acordo com o art.1o, III da Constituição Federal.

Esses, os direitos fundamentais, que também estão amparados pela Dignidade da Pessoa Humana, são mais amplos que os direitos de personalidade. Em suma: os direitos de personalidade asseguram a dignidade nas relações particulares, enquanto que os direitos fundamentais asseguram a dignidade nas relações públicas.

Ocorre que hoje, há o fenômeno da constitucionalização do direito civil, pois os direitos de personalidade, tais como intimidade, vida privada e honra, estão previstos tanto na Constituição Federal quanto no Código Civil. Há um ponto comum entre essas duas fontes do direito, onde a base é o já amplamente citado princípio da dignidade da pessoa humana.

Portanto, os direitos de personalidade podem ser considerados pluridisciplinares, pois não se pode dizer se são de caráter civil ou exclusivamente constitucional, conforme assevera Paulo Lôbo, senão vejamos:

A pluridisciplinaridade permite rica abordagem da matéria, a depender do ângulo da análise. Na perspectiva do direito constitucional, são espécies do gênero direitos fundamentais. Na perspectiva do direito civil, constituem o conjunto de direitos inerentes da pessoa, notadamente da pessoa humana, que prevalecem sobre todos os demais direitos subjetivos privados. (LÔBO, 2015, p. 133).

Os direitos de personalidade compõem um rol não exaustivo de direitos fundamentais e, por isso, pode-se afirmar que é possível a criação de novos direitos, conforme se verifique esta necessidade. Estes poderão ser aplicados nos âmbitos dos três poderes - legislativo, executivo e judiciário. É a chamada, por Daniel Sarmento, de "eficácia irradiante" dos direitos fundamentais (LENZA, 2014, p. 1065). 
Dessa forma, à medida que a sociedade em rede avança e se modifica, é natural que surjam novos direitos a serem tutelados. Contudo, é preciso atenção para a tutela desses direitos emergentes, tal como o direito ao esquecimento, pois estes devem sempre estar ligados a um denominador comum, que, insista-se, é a dignidade da pessoa humana, fato este que vai ao encontro à teoria dos "nós" já mencionada.

Sobre os direitos de personalidade:

Os direitos de personalidade são essenciais à plena existência da pessoa humana, à sua dignidade, ao respeito, à posição nas relações com o estado e com os bens, à finalidade última que move todas as instituições, eis que tudo deve ter como meta maior o ser humano. (RIZZARDO, 2011, p. 137).

Partindo-se da premissa da tutela dos direitos fundamentais e de personalidade, o direito ao esquecimento poderia ser conceituado como um direito não regulamentado no Brasil, que traria a garantia aos indivíduos de não ter informações antigas, verídicas ou não, a seu respeito, retomada por qualquer veículo de comunicação, seja através da mídia, seja através de particulares.

Andre Francez conceitua o direito ao esquecimento da seguinte forma:

0 direito ao esquecimento pode ser definido como o direito da pessoa de apagar informações pretéritas suas e que não têm nenhum interesse público, ou seja, algo que não fere o direito à informação ou à liberdade de expressão e que, também, respeita os princípios constitucionalmente protegidos da intimidade, da vida privada, da honra e da imagem das pessoas (art. 5ํㅗ, X, da CF/88). (FRANCEZ, 2013, pág.201)

Da mesma forma Martinez:

Em outras palavras o direito ao esquecimento é a possibilidade de defesa que, como uma redoma, permite a um particular que não autorize a veiculação ou retire desta um fato pretérito que o expõe ao público em geral, causando-lhe sofrimento ou transtornos. Pode-se dizer que esta esfera de proteção funciona como um mecanismo de isolamento direcionado à informação intertemporal. (MARTINEZ, 2014, pág.81)

No mesmo sentido, Paulo Lobo:

Toda pessoa deve ter garantido o direito de não ser trazido à contemporaneidade fatos ocorridos no passado, ainda que verdadeiros, que lhe causem constrangimentos, sofrimentos ou repercussões negativas em suas atuais relações pessoais, sociais ou profissionais. (LOBO, 2015, pág.146)

Assim, averígua-se que o referido direito emergente está ligado ao direito que cada indivíduo possui de determinar o que quer perpetrar ou não acerca dos dados a respeito de si mesmo, tendo a liberdade de escolha de apagá-los ou retificá-los. Igualmente, acentua-se o direito de não ter aspectos da sua vida expostos sem seu consentimento.

Diante de todo o exposto, o direito ao esquecimento pode considerado um direito de personalidade, sendo, consequentemente, um direito fundamental que servirá para garantir outros direitos, tais como a honra, vida privada e intimidade, direitos estes que já se encontram positivado no texto constitucional brasileiro vigente.

Logo, a divulgação de determinados eventos, ocorridos no passado, poderiam violar direitos intrínsecos aos indivíduos, como os acima mencionados. Por isso, a regulamentação do direito ao esquecimento garantiria que isto não ocorresse, em qualquer meio, seja físico ou através de mídias digitais e eletrônicas.

Dessa forma, determinada notícia, sendo ela verdadeira ou não, vinculada a determinado indivíduo, poderia ser perpetuada eternamente, através de qualquer meio de comunicação, podendo ser retomada a qualquer instante, por qualquer pessoa ou mídia. Com isso, admite-se a possibilidade de que certas informações, se retomadas fora de contexto, poder vir a ferir direitos de personalidade do indivíduo a ela ligado.

Esse repasse de informações pode se dar tanto pela imprensa, tradicional ou eletrônica, que podem visar o lucro, ou não, quanto por particulares, que repassam as informações pelos mais diferentes motivos, muitas vezes irrelevantes. No primeiro caso, em teoria, há a preponderância do interesse público, enquanto que no segundo caso esta característica não é tão marcante. 
Contudo, apesar da presunção de que há interesse público na transmissão de notícias pela mídia, muitas vezes isto não é verdade, pois a mesma, visando o lucro, muitas vezes distorce histórias para atrair a audiência, criando, assim, a chamada "indústria do entretenimento". Devido a essa influência que a mídia exerce sobre as pessoas, ela chegou a ser chamada de "quarto poder" (GAEBLER, Neal. P. 16).

Aqui surge a problemática da colisão dos direitos fundamentais. De um lado, estaria o direito ao esquecimento, ainda não regulamentado, que garantiria proteção à honra, imagem, intimidade e vida privada dos indivíduos, enquanto que de outro lado, estariam os direitos relacionados à liberdade de manifestação de pensamento e de informação, igualmente garantidos constitucionalmente.

Os direitos fundamentais - onde estaria incluído o direito ao esquecimento, posto que o mesmo seria um dos direitos de personalidade - possuem diversas características específicas, dentre as quais, destaca-se a Relatividade ou Limitabilidade, que pode ser associada ao Princípio da Relatividade ou Convivência das Liberdades Públicas, segundo o qual não existem direitos fundamentais absolutos, pois todos eles encontram limites em outros direitos fundamentais, individuais ou coletivos, também consagrados na Carta Magna. Ou seja, se existir um direito fundamental, ele sempre deverá prevalecer sobre os demais. Contudo, em tese, não haveria solução quando houvesse um conflito entre dois direitos absolutos.

Além do princípio supracitado, existem outros princípios instrumentais ou normas que podem ser utilizadas para interpretar a Constituição e resolver eventuais colisões de direitos fundamentais, podendose citar o Princípio da Concordância Prática ou Harmonização, segundo o qual o intérprete, ao invés de afastar totalmente um interesse para a aplicação de outro, deverá conjugar os interesses em conflito, reduzindo proporcionalmente o âmbito de alcance de cada um deles. Em outras palavras, ele não vai excluir totalmente um direito para a aplicação do outro, tampouco irá fazer prevalecer determinado direito para excluir o outro e sim ampliar os ramos da tutela dos já tipificados, como uma rede, mencionada por Castells.

A ideia é a de que nenhum direito consagrado na Constituição Federal pode ser considerado absoluto porque nenhum direito existe isoladamente, mas em conjunto, coexistindo. A partir do momento em que um direito for considerado absoluto, este sempre deverá prevalecer sobre todos os demais. A problemática desta situação está na possibilidade de haver conflito entre dois direitos absolutos. Assim, para que os direitos possam conviver entre si, eles devem ter limites, daí a característica da limitabilidade. Há uma limitação recíproca, ou seja, os direitos impõem limites entre si.

Levando-se em conta a característica da relatividade/limitabilidade dos direitos fundamentais, percebe-se o quão difícil é estabelecer qual o limite do direito ao esquecimento. É impossível descrever expressamente os limites, devendo-se analisar caso a caso os direitos em rota de colisão, através de técnicas como o sopesamento e a ponderação.

Como exemplo de limite ao direito ao esquecimento, poderia-se dizer que seria possível citar um fato, sem mencionar o nome da pessoa ou qualquer outra característica de identificação. Dessa forma, o direito ao esquecimento estaria sendo respeitado ao mesmo tempo que os direitos de informação e manifestação não estariam sendo sacrificados.

O direito de alguém de não ver informações suas serem retomada pelas mídias em geral e o consequente sofrimento que isto acarreta se sobrepõe ao direito de trazer à baila determinados tipos de informações, que não caracterizam interesse público. Por isso é que nesses casos o princípio que assegura a informação à coletividade deve ser mitigado em favor dos direitos de personalidade, muito mais caros.

Norberto Bobbio compartilha a ideia de que, em regra, não existem direitos absolutos, mas aponta duas exceções a esta regra: o direito de não ser escravizado e o direito de não ser torturado. Nesses casos não haveria hipótese em que um desses direitos pudesse ser afastado para que outro fosse ser acobertado (LENZA, 2014).

E mais, em relação às informações perpetradas na internet, o assunto é mais complexo, pois é tarefa quase impossível garantir o direito ao esquecimento neste meio, tendo em vista que a internet tem memória eterna, pois as informações ali perpetradas tendem a permanecer para sempre na web. Ademais, é extremamente difícil rastrear a fonte que primeiro publicou a notícia para eventual responsabilização.

É imprescindível que se perceba que o direito à privacidade e o direito à honra devem ser garantidos pelo nosso ordenamento jurídico, de forma que o ambiente da internet não fique de fora da esfera de proteção do direito. 0 mundo real se tornou paralelo ao mundo virtual, de forma que os direitos assegurados no mundo real devem também ser assegurados no mundo virtual (BOFF, 2014, p.107). 
Em 2014, no Brasil, foi promulgada a Lei 12.965, conhecida como o Marco Civil da Internet, que estabelece princípios, garantias, direitos e deveres para o uso da Internet no Brasil, ou seja, normas para o uso da internet, destacando-se três pontos principais: a proteção da privacidade, a garantia de liberdade do internauta e a neutralidade da rede. Contudo, esta lei não regulamentou o direito ao esquecimento.

Por fim, importante demonstrar o entendimento em sentido contrário, de quem crê que o direito ao esquecimento impediria que fossem contados fatos históricos ou mesmo apagasse a memória, o que dificultaria a delimitação de situações em que operaria o direito de ser esquecido, concedendo muito poder ao julgador e diminuindo as liberdades de expressão e manifestação (SIERRA, 2013).

Contudo, conforme já foi visto, essas liberdades não são absolutas e o direito ao esquecimento tem um cunho muito mais individual do que coletivo. 0 referido direito é íntimo, de cada pessoa, a quem caberá a opção de esquecer, ou não, determinado fato relativo à sua vida pessoal e memória individual.

\subsection{JULGADOS: BRASIL X ESPANHA}

Diante do exposto, passar-se-á a análise dos julgados Espanhóis e Brasileiros que enfrentaram o tema do direito ao esquecimento, a fim de se verificar a forma de regulamentação mais adequada no ordenamento jurídico nacional, através de uma análise comparativa.

Tal estudo abordará a efetiva necessidade de regulamentação, ou não, do direito ao esquecimento como um direito autônomo, bem como se, em não sendo regulamentado, de que forma se dará a solução de eventuais conflitos.

A regulamentação do direito ao esquecimento é importante para que se possa pleitear a proteção de direitos judicialmente e eventual indenização por danos morais em caso de desrespeito, de maneira direta, justificando-se em uma regra e não em princípios, que dariam margem a uma maior discricionariedade do juiz julgador do caso, que poderia, por exemplo, não entender por esta proteção.

Importante salientar que o fato de o direito ao esquecimento não estar positivado não é impeditivo do seu reconhecimento. Segundo Ronaldo Lemos, "o direito ao esquecimento confunde-se com o resultado de uma ponderação entre direitos fundamentais colidentes". Em caso de conflito, caberá ao Poder Judiciário fazer a ponderação dos direitos colidentes e decidir qual deverá prevalecer.

Nos casos envolvendo o direito ao esquecimento, no âmbito do judiciário, há decisões mitigando direito de todos os lados, tanto daquele que postula pelo direito ao esquecimento quanto por aquele que clama pelo direito a livre manifestação do pensamento, a liberdade de informação e de imprensa.

No Brasil, em um caso marcante, a rede de televisão Globo Comunicações exibiu um documentário, em seu programa Linha Direta, onde divulgou nome e sobrenome de um acusado de participar de uma série de assassinatos, em 23 de julho de 1993, conhecidos como Chacina da Candelária. Ocorre que não foi informado no programa que o autor havia sido absolvido dos crimes em sede de julgamento em júri popular, o que lhe causou uma série de transtornos, como dificuldade de conseguir emprego e recebimento de ameaças, obrigando-o a mudar de residência. Por esta razão ingressou com ação pleiteando indenização no valor de 300 salários-mínimos. 
O Superior Tribunal de Justiça se manifestou e no julgamento do Recurso Especial 1.334.097 o relator Luis Felipe Salomão 36 asseverou:

A assertiva de que uma notícia lícita não se transforma em ilícita com o simples passar do tempo não tem nenhuma base jurídica. 0 ordenamento é repleto de previsões em que a significação conferida pelo Direito à passagem do tempo é exatamente o esquecimento e a estabilização do passado, mostrando-se ilícito sim reagitar o que a lei pretende sepultar.

[...]

Como se afirmou anteriormente, ao crime, por si só, subjaz um natural interesse público, caso contrário nem seria crime. E esse interesse público, que é, em alguma medida, satisfeito pela publicidade do processo penal, finca raízes essencialmente na fiscalização social da resposta estatal que será dada ao fato.

Se é assim, o interesse público que orbita o fenômeno criminal tende a desaparecer na medida em que também se esgota a resposta penal conferida ao fato criminoso, a qual, certamente, encontra seu último suspiro com a extinção da pena ou com a absolvição, ambas consumadas irreversivelmente.

E é nesse interregno temporal que se perfaz também a vida útil da informação criminal, ou seja, enquanto durar a causa que a legitimava. Após essa vida útil da informação, seu uso só pode ambicionar, ou um interesse histórico, ou uma pretensão subalterna, estigmatizante, tendente a perpetuar no tempo as misérias humanas.

Não se pode, pois, nesses casos, permitir a eternização da informação. [...]

E é por essa ótica que o direito ao esquecimento revela sua maior nobreza, pois afirma-se, na verdade, como um direito à esperança, em absoluta sintonia com a presunção legal e constitucional de regenerabilidade da pessoa humana.

Assim, nesse caso restou julgado o deferimento do pleito do Autor, sendo-lhe deferida indenização no valor de $\mathrm{R} \$ 50.000,00$ (cinquenta mil reais).

Porém decisão diferente foi tomada no Recurso Especial no 1.335.153. Nesse caso os irmãos de Aida Cury, assassinada no ano de 1958, pleitearam indenização em razão de a história do assassinato de sua irmã haver sido exibida pela Rede Globo no mesmo programa Linha Direta, o que, segundo os Autores, feriria seu direito ao esquecimento, fazendo-os reviver a dor pela morte da irmã.

\footnotetext{
36BRASIL. Superior Tribunal de Justiça. Recurso Especial que manteve a condenação da Globo por ter veiculado o nome do autor como envolvido no chamado massacre da Candelária a despeito de ele ter sido absolvido. REsp no 1334.097. Globo Comunicações e Participações Ltda e Jurandir Gomes de França. Relator: Ministro Luis Felipe Salomão. $25 \quad$ de novembro $\quad$ de $2013 . \quad$ Disponível $\quad$ em: $<$ https://ww2.stj.jus.br/processo/pesquisa/src=1.1.3\&aplicacao=processos.ea\&tipoPesquisa=tipoPesquisaGenerica\& num_registro=201201449107>. Acesso em: 16 junho 2015.
} 
No julgamento o ministro Luis Felipe Salomão ${ }^{37}$ explicitou:

Em um crime de repercussão nacional, a vítima - por torpeza do destino frequentemente se torna elemento indissociável do delito, circunstância que, na generalidade das vezes, inviabiliza a narrativa do crime caso se pretenda omitir a figura do ofendido. Tal pretensão significaria, em última análise, por exemplo, tentar retratar o caso DorotyStang, sem DorotyStang; o caso Vladimir Herzog, sem Vladimir Herzog, e outros tantos que permearam a história recente e passada do cenário criminal brasileiro. 11.2. Com efeito, o direito ao esquecimento que ora se reconhece para todos, ofensor e ofendidos, não alcança o caso dos autos, em que se reviveu, décadas depois do crime, acontecimento que entrou para o domínio público, de modo que se tornaria impraticável a atividade da imprensa para o desiderato de retratar o caso Aida Curi, sem Aida Curi. É evidente ser possível, caso a caso, a ponderação acerca de como o crime tornou-se histórico, podendo o julgador reconhecer que, desde sempre, o que houve foi uma exacerbada exploração midiática, e permitir novamente essa exploração significaria conformar-se com um segundo abuso só porque o primeiro já ocorrera. Porém, no caso em exame, não ficou reconhecida essa artificiosidade ou o abuso antecedente na cobertura do crime, inserindo-se, portanto, nas exceções decorrentes da ampla publicidade a que podem se sujeitar alguns delitos.

Verifica-se, portanto, que neste caso não foi reconhecido o direito ao esquecimento dos Autores, entendendo-se que é impossível não abordar a figura da ofendida, no caso Ainda Cury.

Também configura caso de direito ao esquecimento o caso da apresentadora de TV, Xuxa Meneghel, que conseguiu o direito de ver removido o vídeo erótico denominado "Amor Estranho Amor" de que participou no início de sua carreira, quando ainda era menor de idade (PINTO, 2012).

Neste caso, mesmo que a apresentadora tenha autorizado a divulgação de sua imagem no passado, sua carreira atual tomou sentido contrário àquele fato pretérito, de forma que o direito à exibição das imagens entra em confronto com o direito à intimidade (SCHREIBER, 2013, Online).

Já na Espanha, um cidadão protocolou pedido junto à Agência Espanhola de Proteção de Dados - AEPD, com o objetivo de que fossem suprimidos dos mecanismos de busca, notícias publicadas no jornal $L a$ Vanguardia, no ano de 1998, que noticiava o fato de que o requerente teve seus bens levados à hasta pública por não ter quitado dívidas com a seguridade social. 0 referido cidadão teve seu pleito atendido pela Agência, que entendeu ser cabível seu pleito.

Inconformadas com a decisão da autarquia espanhola, as empresas Google Spain e Google Inc. ajuizaram recurso perante a Audiência Nacional, órgão judiciário da Espanha com competência sobre todo o território do País, de cujos julgamentos cabe recurso para o Tribunal Supremo da Espanha. Como a questão envolvia interpretação da Diretiva 95/46, relativa à proteção das pessoas naturais no que diz respeito ao tratamento de dados pessoais em âmbito de União Europeia, a questão foi remetida à apreciação do Tribunal de Justiça da União Europeia que, em 13 de maio de 2014, concluiu que o tratamento de dados que os motores de busca realizam está submetido às normas de proteção de dados da União Europeia, sendo que as pessoas têm direito de solicitar, mediante certas condições, que determinadas vinculações a seus dados pessoais não figurem entre os resultados nos mecanismos de busca da Internet.

É notório, portanto, a importância e contemporaneidade do tema no contexto social e jurídico, tanto no Brasil, quanto no exterior. Com o crescente número de demandas que procuram garantir um direito ao esquecimento como pressuposto do respeito à dignidade da pessoa humana e também como garantidor de outros direitos fundamentais, torna-se indispensável estabelecer parâmetros para avaliação do que pode ou não ser suprimido em caso de divulgação de dados e informações pessoais na Internet.

A Espanha foi escolhida devido ao fato de que foi a partir de provocação judicial feita pelo cidadão espanhol Mário Costeja González que o Tribunal de Justiça da União Europeia decidiu pela aplicação do

37 BRASIL. Superior Tribunal de Justiça. Recurso Especial que negou provimento ao pleito dos autores que buscavam indenização em razão da veiculação do homicídio de Aida Cury ocorrido em 1958. Globo Comunicações e Participações Ltdae Nelson Cury. Relator: Ministro Luis Felipe Salomão. 19 de agosto de 2014. Disponível em: $<$ https://ww2.stj.jus.br/processo/pesquisa/src=1.1.3\&aplicacao=processos.ea\&tipoPesquisa=tipoPesquisaGenerica\& num_registro $=201100574280$. 
direito ao esquecimento em mecanismos de busca na Internet. Também contribuiu para a escolha o fato de que a Espanha previu em sua Constituição a garantia de proteção da intimidade com relação ao tratamento informatizado de dados pessoais.

Ainda, foi considerado que a Espanha, passou por um período ditatorial que durou trinta e sete anos, sendo que a Constituição atualmente vigente naquele país foi sancionada após o referido período em que o País foi regido de forma autoritária por Francisco Franco. Assim, de forma semelhante ao ocorrido no Brasil, a Constituição atualmente vigente na Espanha foi forjada em um ambiente de supressão de direitos, já que ambos os países foram regidos por governos marcadamente repressores e com histórico de violência ${ }^{38}$.

\section{CONSIDERAÇÕES FINAIS}

Hoje a solução das colisões de direitos fundamentais já positivados, bem como do direito ao esquecimento, ainda não regulamentado no Brasil, dá-se através dos princípios instrumentais, posto que são um forma de garantia dos direitos fundamentais já tipificados.

Contudo, defendeu-se neste trabalho a positivação e regulamentação do direito ao esquecimento a fim de garantir a tutela dos direitos fundamentais já existentes e amplamente citados anteriormente, tais como, honra, intimidade e vida privada.

Dessa forma, percebeu-se que não há solução predeterminada para resolução do embate entre o direito ao esquecimento e o direito à informação e manifestação de pensamento, devendo sempre ser analisado o caso concreto. Isto se dá, posto que não há hierarquia entre direitos fundamentais, de tal forma que não há como formar uma regra que se sobreponha à outras.

Analisando tudo que foi dito, pode-se concluir que o direito ao esquecimento não busca apagar fatos históricos, que contenham interesse público na sua divulgação, pois estes pertencem à memória comum, de todo o povo, até mesmo do futuro. 0 referido direito possui caráter individual, pois se trata do direito de alguém não ver notícia sua relacionada a seu passado sempre ser retomada em um momento em que já não existe mais interesse nessa divulgação, podendo, inclusive, gerar danos a outros direitos, como os de personalidade.

Entretanto, ainda que se decida por garantir o direito ao esquecimento, é extremamente difícil de se ter o controle das informações que se deseja esquecer quando estas são veiculadas na internet. Em razão disso, mostra-se necessário uma análise da comunicação no ambiente virtual, bem como do tratamento concedido aos dados informacionais no Brasil e no exterior.

Por fim, essencialmente, é preciso deixar elucidado que a garantia do direito ao esquecimento não implica, necessariamente, a proibição de divulgação de dados e informações, pois estas podem encontrar limites para proteção de direitos individuais que não afetem estes direitos de interesse público.

\section{REFERÊNCIAS}

[1] Boff, Salete Oro. Lippstein, Daniela. Privacidade de dados e direitos humanos: a necessária adoção de mecanismos para a proteção de dados na era digital. In: Cervi; Mauro Luiz; Jahneke; Letícia Thomasi, Stahlöfer, Iásin Schäffer (Org.). Pensando o Direito. v. IV. São Paulo: Letras Jurídicas, 2014.

[2] Bonavides, Paulo. Curso de Direito Constitucional. 25 ed. P.569

[3] Canotilho, J.J. Gomes. Direito Constitucional e Teoria da Constituição. 5ª Ed. Coimbra, 2002.

[4] Castells, Manuel. A sociedade em Rede. Vol. 1. Trad. Roneide Venancio Majer com a colaboração de Klauss Brandini Gerhardt. 8 ed. São Paulo: Paz e Terra, 2005.

[5] Francez. André. Direito do entretenimento na Internet, São Paulo: Saraiva, 2013.

[6] Gaebler, Neal. Vida, o filme: Como o entretenimento conquistou a Realidade. Companhia das Letras.

[7] Lenza, Pedro. Direito Constitucional Esquematizado. São Paulo: Saraiva, 2014. 18. ed.

[8] Limberger; Têmis. 0 direito à intimidade na era da informática: A necessidade de proteção dos dados

38 A Constituição do Brasil de 1988 surge após a ditadura militar, tendo por inspiração o constitucionalismo jovem europeu, sendo que institutos como o Habeas Data foi inspirado na previsão existente na Constituição Espanhola . (LIMBERGER, 2007, p. 31) 
pessoais. Porto Alegre: Livraria do Advogado, 2007.

[9] Lôbo, Paulo. Direito civil: parte geral. São Paulo Saraiva, 2015. 5. ed.

[10] Martinez; Pablo Dominguez. Direito ao Esquecimento: A proteção da memória individual na sociedade de informação. Rio de Janeiro: Lumen Juris, 2014.

[11] Pinto, Cristiano Vieira Sobral. Direito Civil Sistematizado. Rio de Janeiro: Forense, 2012. 4.ed.Online

[12] Rizzardo, Arnaldo. Parte Geral do Código Civil. Rio de Janeiro: Forense, 2011. 7. ed. p. 137.

[13] Sarlet, I.W., A eficácia dos direitos fundamentais. 10 ed. P. 51.

[14] Schreiber, Anderson. Direitos da personalidade.2. ed. São Paulo: Atlas, 2013. Online

[15] Sierra, Joana de Souza. Um estudo de caso: o direito ao esquecimento contra a Liberdade de imprensa. Florianópolis: UFSC, 2013. 89 p. Monografia (Graduação) - Curso de Direito, Universidade Federal de Santa Catarina, Florianópolis, 2013. 


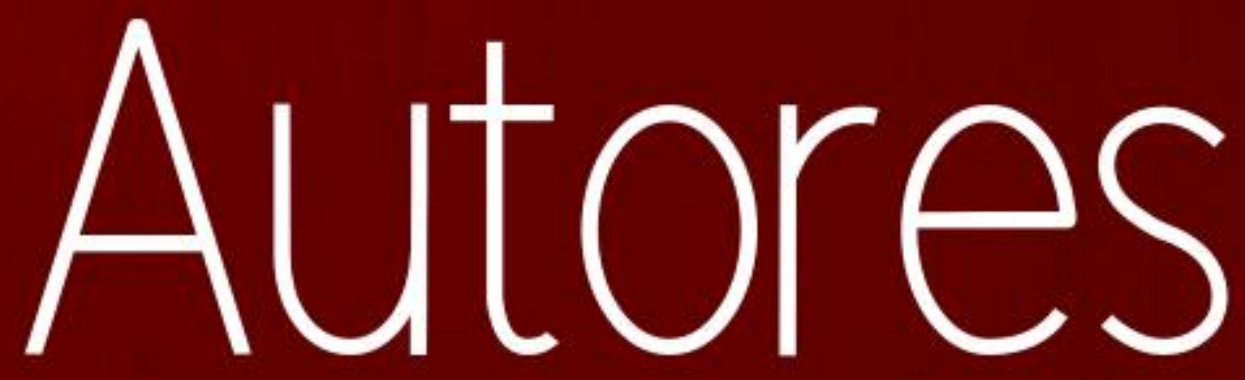




\section{AMANDA MARIA CUNHA MENEZES}

Graduada em Serviço Social pela Universidade Federal de Pernambuco (UFPE). Mestranda em Serviço Social pela Universidade Federal de Pernambuco (UFPE).

\section{ANA VIRGINIA DO NASCIMENTO MOREIRA}

Graduada em Serviço Social pela Universidade Estadual da Paraíba (UEPB). Mestranda em Serviço Social pela Universidade Federal de Pernambuco (UFPE).

\section{ANDRÉA VETTORASSI}

Bacharel e mestre em Ciências Sociais pela UFSCar e doutora em Sociologia pela Unicamp. É professora adjunta da Faculdade de Ciências Sociais e do Programa de Pós-graduação em Sociologia da UFG. Atua em pesquisas relacionadas aos fluxos migratórias, memória social, relações de trabalho e identitárias.

\section{ANNA LÚCIA NOSCHANG DA SILVA}

Possui graduação em DIREITO pela Faculdade de Direito de Santa Maria - FADISMA (2012). Atualmente é advogada - Ordem dos Advogados do Brasil - Seccional do Rio Grande do Sul no escritório Anna Noschang \& Richard Maicá Advocacia e Consultoria. Tem experiência na área de Direito Civil, com ênfase em Direito de Família. É Mestre pelo Programa de Pós Graduação em Direito da Universidade Federal de Santa Maria (UFSM) - Área de Concentração: Direitos Emergentes da Sociedade Global; Linha de Pesquisa: Direitos na Sociedade em Rede. Já lecionou na Faculdade Dom Alberto, em Santa Cruz do Sul/RS. É professora de Direito Civil.

\section{ANTÔNIO SOUSA MARTINS FILHO}

Formou-se Técnico Agrícola, nível médio Em 1980 na escola agrotécnica federal do Maranhão, e atualmente Cursa Direito Pelo Centro Universitário Estácio da Amazônia.

\section{CAROLINE HENTGES}

Graduada em Administração pela Universidade Federal da Fronteira Sul (UFFS).

\section{CINDY DAMARIS GOMES LIRA}

Mestranda do Programa de Pós-graduação em Cognição, Tecnologias e Instituições - PPGCTI pela Universidade Federal Rural do Semi-Árido (UFERSA). Licenciada e Bacharela em Enfermagem pela Universidade do Estado do Rio Grande do Norte- UERN. Pesquisadora assistente do Observatório de Violência do Rio Grande do Norte- OBVIO RN. Docente na Faculdade de Enfermagem Nova Esperança de Mossoró - FACENE.

\section{CLAUDIMARA CASSOLI BORTOLOTO}

Doutora em Ciências Sociais pela UNESP de Araraquara. Professora da Universidade Tecnológica Federal do Paraná - UTFPR

\section{DÉBORA CRISTINA MARINHO GUIMARÃES}

Formada em técnico em hospedagem, pela escola estadual Ayrton Senna e Acadêmica do Curso de Bracharelado em Direito pelo Centro Universitário Estácio da Amazônia. 


\section{DOACIR GONÇALVES DE QUADROS}

Doutor em Sociologia (UFPR) . Professor de Ciência Política e do Programa de Pós-Graduação Stricto Sensu em Direito: Mestrado Acadêmico do Centro Universitário UNINTER. Coordenador do projeto de pesquisa Justiça e poder político: a relação entre o campo judiciário e campo político e a apropriação do direito como recurso de luta política vinculado ao PPGD- UNINTER. Tem experiência na área das Ciências Sociais atuando como pesquisador nos seguintes temas: Teoria Política, Estado, Sociologia Política e Poder Judiciário, Eleições, Partidos Políticos, Comportamento Politico e Comunicação Política.

\section{EDEMAR ROTTA}

Graduado em Filosofia pela Faculdade de Filosofia Ciências e Letras Dom Bosco (1985), com habilitação plena para o exercício do magistério em filosofia, sociologia e história. Especialista em Educação pela FAFI/Dom Bosco (1988). Especialista em Filosofia pela FAFI/Dom Bosco (1990). Mestre em Sociologia pela Universidade Federal do Rio Grande do Sul (1998). Doutor em Serviço Social pela Pontifícia Universidade Católica do Rio Grande do Sul (2007). Pós-doutorado em Serviço Social - PUCRS. Professor da Universidade Regional do Noroeste do Estado do Rio Grande do Sul (UNIJUI), de março de 1987 a fevereiro de 2010. Professor da educação básica do Estado do Rio Grande do Sul, de março de 1990 a fevereiro de 2010. Coordenador Acadêmico na UFFS, Campus Cerro Largo, de janeiro de 2010 a fevereiro de 2011. Diretor do Campus Cerro Largo, da UFFS, de fevereiro de 2011 a agosto de 2015. Professor da Universidade Federal da Fronteira Sul (UFFS), integrando o quadro permanente do Programa de Pós-Graduação em Desenvolvimento e Políticas Públicas - Mestrado. Atua nas áreas de Sociologia (fundamentos, sociologia do desenvolvimento, sociologia do trabalho, sociologia brasileira e sociologia jurídica), Serviço Social (fundamentos de políticas sociais) e Interdisciplinar (Desenvolvimento e políticas públicas sociais). Pesquisador na área de desenvolvimento, gestão social e políticas sociais.

\section{EDSON JUAN FERREIRA NASCIMENTO}

\section{ACADEMICO DO CURSO DE SEGURANÇA DO TRABALHO PELA UNIVERSIDADE PAULISTA.}

\section{FABÍOLA CRISTINA CARRERO}

Possui graduação em Direito pela Universidade Norte do Parana (2005). Especialista em Direito Empresarial pela Universidade Estadual de Londrina. Mestre em Direitos da Personalidade pela Unicesumar. Professora do CENTRO DE ENSINO SUPERIOR DE APUCARANA, ministrando as disciplinas de Direito Processual do Trabalho I, Direito Previdenciário I e Supervisora de Estágio. Professora na Faculdade de Tecnologia e Ciências do Norte do Paraná, campus Paranavaí. Atua como advogada no escritório Ferreira, Carrero e Advogados, com ênfase em Direito Previdenciário, Trabalhista e Empresarial.

\section{GLEICEMERI DE VITO MONARO}

Formada em Ciências Biológicas pela Faculdade de Apucarana-PR (2013). Especialista em Educação Especial Inclusiva (2014). Professora Municipal na Prefeitura de Marilândia do Sul-PR. Acadêmica do $10^{\circ}$ semestre de Direito pela Faculdade de Apucarana-PR. Participou do programa de monitoria com a disciplina de Introdução do Estudo de Direito (2017). Aprovada no XXVIII Exame de Ordem Unificado (2019).

\section{GUILHERME STREIT CARRARO}

Mestre em Direito pela Universidade de Marília. Especialista em Direito Notarial e Registral pela Universidade Anhanguera - Uniderp. Especialista em Direito e Processo do Trabalho pela Universidade Anhanguera - Uniderp. Possui graduação em Direito pela Universidade Federal de Santa Maria (2009). Atualmente é Oficial Registrador do Cartório de Registro de Imóveis de Rancharia - SP. 


\section{IARA MARIANA DE FARIAS NÓBREGA}

Mestranda do Programa de Pós-Graduação em Cognição, Tecnologia e Instituição da Universidade Federal Rural do Semi-Árido (Ufersa), possui graduação em Administração pela UFERSA (2019) e em Jornalismo pela Universidade Maurício de Nassau (2008). Participa da Escola de Jovens Líderes do RN e atua como freelancer na area de gestão de mídias sociais e assessoria de imprensa.

\section{IVANN CARLOS LAGO}

Possui graduação em Ciências Sociais pela Universidade do Vale do Itajaí - UNIVALI - (2001), mestrado (2005) e doutorado (2010) em Sociologia Política pela Universidade Federal de Santa Catarina. Atua no Ensino Superior desde 2003, desenvolvendo tanto atividades ligadas à docência e pesquisa quanto de gestão e administração. Também exerceu atividades de consultoria nas áreas de políticas públicas, planejamento governamental e marketing político/eleitoral. Atualmente é professor assistente da Universidade Federal da Fronteira Sul - UFFS -, Campus Cerro Largo (RS), onde exerceu, entre 2011 e 2015, a função de Coordenador Acadêmico do Campus. Atualmente desempenha a função de Diretor do Campus Cerro Largo da UFFS, onde também é professor do quadro permanente do Programa de Mestrado em Desenvolvimento e Políticas Públicas. Suas áreas de pesquisa são: Ideias, Instituições e Práticas Políticas; Partidos e Eleições; Conexão Eleitoral; Teoria Política; Cultura e Desenvolvimento.

\section{IVENIO DO ESPIRITO SANTO HERMES JUNIOR}

Criminalista, Mestre em Cognição, Tecnologias e Instituições pela Universidade Federal Rural do Semi-Árido UFERSA, Arquiteto e Urbanista, Cientista Criminal, Escritor e Pesquisador. Pósgraduado em Gestão e Políticas de Segurança Pública, com cursos diversos na área de gestão de informações, coleta de dados, investigações criminais, gestão de pessoas, e outros. Escritor vencedor do Prêmio Literário Tancredo Neves. Possui em sua bibliografia 18 livros publicados, sendo 2 de ficção policial, 3 de reflexões poéticas, e 11 sobre gestão e políticas em segurança pública. Atualmente exerce as funções de Coordenador de Estatísticas e Análises Criminais da Secretaria da Segurança Pública e da Defesa Social do Rio Grande do Norte e é pesquisador do OBVIO - Observatório da Violência do Rio Grande do Norte, Departamento de Ciências Humanas da UFERSA (Universidade Federal Rural do Semi-Àrido), Consultor da Comissão de Segurança Pública e Política Carcerária da OAB RN, Consultor de Segurança da UFRN - Universidade Federal do Rio Grande do Norte e Associado Pleno do FBSP - Fórum Brasileiro de Segurança Pública.

\section{LORRANY DOS SANTOS FERREIRA}

Licenciada em Ciências Sociais e especialista em História e Narrativas Audiovisuais pela Universidade Federal de Goiás; Mestranda em Sociologia pela mesma instituição onde pesquisa temas como: juventude rural, educação e identidade.

\section{MARIA PAULA DA ROSA FERREIRA}

Advogada. Mestre em Direito pela Universidade Federal de Santa Maria - PPGD/UFSM - Linha I Direitos da Sociobiodiversidade e Sustentabilidade. Dissertação de mestrado aprovada com indicação para publicação por excelência. Especialização em andamento em Direito Processual Civil pela Universidade Franciscana (UFN). Graduada em Direito pela Universidade Franciscana, UFN, com Láurea Acadêmica como mérito acadêmico pelo exemplar desempenho no ensino, pesquisa e extensão no Curso de Direito.

\section{MIRIAM BARBOSA SOARES}

Graduando Gestao Portuária. Bacharel em Teologia Capelã 


\section{NATHALIE DE AZEVEDO KJAER}

Acadêmica do Curso de Bacharelado em Direito pelo Centro Universitário Estácio da Amazônia, escritora e pesquisadora.

\section{PAULO HENRIQUE PAVOLAK}

Possui graduação em Bacharelado em Direito pela Faculdade de Apucarana (2007). Especialização em Perícia Criminal pelo UNICESUMAR (2008). Mestrando em Ciências Jurídicas pelo Unicesumar (2015). Atualmente é advogado, coordenador e professor do curso de Direito da FAP - Faculdade de Apucarana.

\section{PEDRO MARCHIORO}

Doutorando em Sociologia pela Universidade Federal do Paraná e bolsista da CAPES, atualmente pesquisa a migração haitiana no Brasil.

\section{PEDRO ROBERTT NIZ}

Atualmente é Professor Associado da Universidade Federal de Pelotas, atuando no Programa de Pós-graduação em Sociologia e no Programa de Pós-graduação em Ciência Política. Tem se aprofundado na área de Sociologia do Trabalho pesquisando os seguintes temas: Reestruturação Produtiva, Flexibilidade, Classe Trabalhadora e Nova ética do capitalismo. Na atualidade vêm desenvolvendo pesquisas sobre com trabalhadores e ex-trabalhadores da Indústria Naval na cidade de Rio Grande/RS, sendo um dos coordenadores do NEPN (Núcleo de Estudos sobre o Polo Naval).

\section{RODRIGO CRISTIANO DIEHL}

Doutorando e Mestre em Direito pela Universidade de Santa Cruz do Sul, ambos com bolsa Prosuc/CAPES. Mestrando em Política Social e Serviço Social pela Universidade Federal do Rio Grande do Sul. Especialista em Direito Constitucional e Administrativo pela Universidade Estácio de Sá. Especialista em Gestão Pública Municipal pela Universidade Federal de Santa Maria. Bacharel em Direito pela Universidade de Santa Cruz do Sul. Bacharelando em Administração Pública pela Universidade Federal do Pampa. Integrante do Observatório do Estado LatinoAmericano - ODELA. Integrante do Comitê de Direitos Humanos para a promoção da diversidade cultural (UNISC). Integrante do Núcleo de Estudos e Pesquisas em Saúde e Trabalho (NEST/UFRGS). Integrante do Núcleo de Estudos Políticos e Administrativos (NEPA/UFRGS).

\section{ROMER MOTTINHA SANTOS}

Mestre em Ciência Política pela Universidade Federal do Paraná (UFPR) e Especialista em Mídias Integradas na Educação (UFPR); Especialista (MBA - Master of Business Administration) em Gestão Estratégica de Marketing (Uninter) e Bacharel em Ciência Política pelo Centro Universitário Internacional (Uninter); Membro do Grupo de Pesquisas "Comunicação Política, Elites e Políticas Públicas" (Uninter); Atua na Secretaria da Educação do Paraná.

\section{ROSANE BEATRIS MARIANO DA ROCHA BARCELLOS TERRA}

Doutora em Direito pela Universidade de Santa Cruz do Sul - UNISC, com bolsa CAPES (2015). Mestre em Direito pela Universidade de Santa Cruz do Sul - UNISC (2006). Especialista em Pesquisa pelo Centro Universitário Franciscano - UNIFRA (2005). Graduada em Direito pela Universidade do Vale do Rio dos Sinos - UNISINOS (1990). Professora da Universidade Franciscana - UFN, onde também atua como pesquisadora. Destaca-se pela produção de artigos e capítulos de livros, bem como participações, defesas, apresentações e presidência de mesas em Congressos e Seminários voltados à área do Direito e áreas correlatas. Integrante do Grupo de Pesquisas e Estudos Teoria Jurídica no Novo Milênio, do curso de Direito da UFN. 


\section{RUI MACHADO JUNIOR}

Mestranda do Programa de Pós-graduação em Cognição, Tecnologias e Instituições - PPGCTI pela Universidade Federal Rural do Semi-Árido (UFERSA). Licenciada e Bacharela em Enfermagem pela Universidade do Estado do Rio Grande do Norte- UERN. Pesquisadora assistente do Observatório de Violência do Rio Grande do Norte- OBVIO RN. Docente na Faculdade de Enfermagem Nova Esperança de Mossoró - FACENE.

\section{THADEU DE SOUSA BRANDÃO}

Sociólogo, Mestre e Doutor em Ciências Sociais pela UFRN (Universidade Federal do Rio Grande do Norte). Professor Adjunto de Sociologia do Departamento de Ciências Humanas da da UFERSA (Universidade Federal Rural do Semi-Ârido). Autor de "Atrás das Grades: habitus e interação social no sistema prisional" e coautor de "Rastros de Pólvora: Metadados 2015", "Observatório Potiguar 2016: Mapa da Violência do RN" e "Observatório Potiguar 2017: Mapa da Violência do RN", dentre outros, além de artigos qualis e relatórios de pesquisa. Coordenador do OBVIO - Observatório da Violência do Rio Grande do Norte, Grupo de Estudos do Centro de Ciências Sociais Aplicadas e Humanas (CCSAH) da UFERSA (Universidade Federal Rural do Semi-Àrido). Membro da Rede de Pesquisa Brasileira em Sociologia Econômica, Consultor Ad Hoc da Comissão de Direitos Humanos e da Comissão de Segurnça Pública da OAB/RN (Secção Natal) e Membro da Câmara Técnica de CVLIs (Condutas Violentas Letais Intencionais) da SESED (Secretaria de Defesa Social e Segurança Pública) do RN.

\section{THAIS TAVARES BERNARDO}

Graduada em Serviço Social - UFF. Mestre em Serviço Social - UERJ. Doutora em Serviço Social PUC/SP

\section{VALÉRIA RIBAS DO NASCIMENTO}

Doutora em Direito Público pela Universidade do Vale do Rio dos Sinos (UNISINOS), com período de pesquisa na Universidad de Sevilla (US); Pós-doutora pela Pontifícia Universidade Católica do Rio Grande do Sul (PUCRS); Mestre em Direito Público pela Universidade de Santa Cruz do Sul (UNISC); Graduada em Direito pela Universidade Federal de Santa Maria (UFSM); Professora do Programa de Pós-Graduação em Direito da UFSM; Professora Adjunta do Departamento de Direito da UFSM. Já lecionou, também, na Faculdade de Direito de Santa Maria (FADISMA); Universidade Regional Integrada do Alto Uruguai e das Missões (URI) - Santo Ângelo; Universidade Regional do Noroeste do Estado do Rio Grande do Sul (UNIJUÍ) e Universidade do Vale do Rio dos Sinos (UNISINOS). Atua principalmente com os seguintes temas: Teoria do Estado, Direito Constitucional, Direito Administrativo e Direito Internacional. Membro do Conselho Nacional de Pesquisa e Pós-Graduação em Direito (CONPEDI) e da Associação Brasileira do Ensino do Direito (ABEDI). Coordenadora do Núcleo do Direito Constitucional (NDC) da Universidade Federal de Santa Maria (UFSM), com bolsa de fomento do CNPQ/CAPES Edital Chamada MCTI/CNPq/MEC/CAPES n.o 07/2011. 


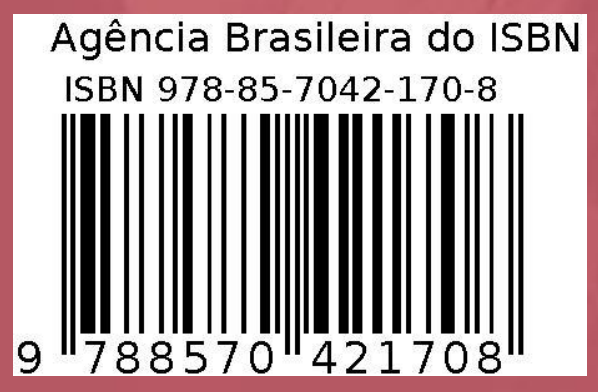

